\title{
Cytomegalovirus as a possible risk factor for atherosclerosis : a study in the mouse
}

Citation for published version (APA):

Vliegen, I. (2003). Cytomegalovirus as a possible risk factor for atherosclerosis : a study in the mouse. [Doctoral Thesis, Maastricht University]. Datawyse / Universitaire Pers Maastricht. https://doi.org/10.26481/dis.20031210iv

Document status and date:

Published: 01/01/2003

DOI:

10.26481/dis.20031210iv

Document Version:

Publisher's PDF, also known as Version of record

\section{Please check the document version of this publication:}

- A submitted manuscript is the version of the article upon submission and before peer-review. There can be important differences between the submitted version and the official published version of record.

People interested in the research are advised to contact the author for the final version of the publication, or visit the DOI to the publisher's website.

- The final author version and the galley proof are versions of the publication after peer review.

- The final published version features the final layout of the paper including the volume, issue and page numbers.

Link to publication

\footnotetext{
General rights rights.

- You may freely distribute the URL identifying the publication in the public portal. please follow below link for the End User Agreement:

www.umlib.nl/taverne-license

Take down policy

If you believe that this document breaches copyright please contact us at:

repository@maastrichtuniversity.nl

providing details and we will investigate your claim.
}

Copyright and moral rights for the publications made accessible in the public portal are retained by the authors and/or other copyright owners and it is a condition of accessing publications that users recognise and abide by the legal requirements associated with these

- Users may download and print one copy of any publication from the public portal for the purpose of private study or research.

- You may not further distribute the material or use it for any profit-making activity or commercial gain

If the publication is distributed under the terms of Article $25 \mathrm{fa}$ of the Dutch Copyright Act, indicated by the "Taverne" license above, 
Cytomegalovirus as a possible risk factor for atherosclerosis

$\sim$ A study in the mouse

\author{
Inge Vliegen \\ Maastricht, 2003
}


(c) I. Vliegen, Maastricht 2003

ISBN 90-9017-449-4

Tekening omslag: René Vliegen

Druk: Datawyse/ Universitaire Pers Maastricht 


\title{
Cytomegalovirus as a possible risk factor for atherosclerosis
}

\author{
$\sim A$ study in the mouse
}

\section{PROEFSCHRIFT}

ter verkrijging van de graad van doctor aan de Universiteit Maastricht, op gezag van de Rector Magnificus,

Prof. Dr. A.C. Nieuwenhuijzen Kruseman volgens het besluit van het College van Decanen, in het openbaar te verdedigen op woensdag 10 december 2003 om 12.00 uur

door

Inge Vliegen

Geboren te Tongeren (België) op 23 januari 1977 


\section{Promotores}

Prof. dr. C.A. Bruggeman

Co-promotores

Dr. F.R.M. Stassen

Dr. A.M. Duijvestijn

Beoordelingscommissie

Prof. dr. M.J.A.P. Daemen (voorzitter)

Prof. dr. M. Borgers

Prof. dr. M.H. Hofker

Prof. dr. J.G. de Mey

Dr. J. Neyts (Rega-Instituut, K.U. Leuven, België)

Prof. dr. H.W. Steinbusch

Financial support by the Netherlands Heart Foundation and Vavantas Riemst for the publication of this thesis is gratefully acknowledged. 
Aan

Michaël

mama en papa 



\section{A66reviations}

\begin{tabular}{|c|c|}
\hline ApoE & Apolipoprotein E knockout \\
\hline $\mathrm{B} 6$ & C57BL/6J \\
\hline $\mathrm{BALB} / \mathrm{c}$ & Mouse strain \\
\hline C57BL/6J & Mouse strain \\
\hline CMV & Cytomegalovirus \\
\hline CPE & Cytopathological effect \\
\hline $\mathrm{Ct}$ & Threshold cycle \\
\hline DABSYL & Fluorophore (quencher) \\
\hline ELISA & Enzyme linked immuno sorbent assay \\
\hline $\mathrm{F} 4 / 80$ & Anti-macrophage antibody \\
\hline FAM & Fluorophore (reporter) \\
\hline FITC & Fluorescent dye \\
\hline FSC & Forward scatter \\
\hline GAPDH & Glyceraldehyde-3-phosphate dehydrogenase \\
\hline $\mathrm{gB}$ & Glycoprotein B \\
\hline $\mathrm{gH}$ & Glycoprotein $\mathrm{H}$ \\
\hline IE & Immediate early \\
\hline IFN & Interferon \\
\hline IL & Interleukin \\
\hline JOE & Fluorophore (reporter) \\
\hline LDLrec & LDL receptor knockout \\
\hline LPS & Lipopolysaccharide \\
\hline $\mathrm{m}_{\varphi}$ & Macrophage \\
\hline MCMV & Murine CMV \\
\hline MEF & Mouse embryonic fibroblasts \\
\hline $\mathrm{MHC}$ class I/II & Major histocompatibility complex class $\mathrm{I} / \mathrm{II}$ \\
\hline MOI & Multiplicity of infection \\
\hline mRNA & Messenger RNA \\
\hline MSFM & Macrophage serum free medium \\
\hline NASBA & Nucleic acid sequence based amplification \\
\hline ORF & Open reading frame \\
\hline OxLDL & Oxidized LDL \\
\hline PE & Fluorescent dye \\
\hline p.i. & Post infection or post injection \\
\hline PCR & Polymerase chain reaction \\
\hline PEC & Peritoneal exudate cells \\
\hline PFU & Plaque forming units \\
\hline RCMV & Rat CMV \\
\hline RT-PCR & Reverse transcriptase PCR \\
\hline SSC & Sideward scatter \\
\hline Sm & Spleen macrophages \\
\hline SMC & Smooth muscle cells \\
\hline TAMRA & Fluorophore (quencher) \\
\hline Th & T helper \\
\hline TNF & Tumor necrosis factor \\
\hline UV-MCMV & UV-inactivated MCMV \\
\hline
\end{tabular}





\section{Contents}

Chapter 1 General Introduction 11

Chapter 2 MCMV infection increases early T-lymphocyte influx in $\quad 47$ atherosclerotic lesions in apoE knockout mice

Chapter 3 Improved detection and quantification of mouse cytomegalovirus by real-time PCR

Chapter 4 MCMV antigens stimulate T cell influx in atherosclerotic lesions thereby aggravating atherosclerosis in apo $\mathrm{E}^{-1 .}$ mice

Chapter 5 Murine cytomegalovirus infection directs macrophage differentiation into a pro-inflammatory immune phenotype: implications for atherogenesis

Chapter 6 Cytomegalovirus infection aggravates atherogenesis in apoE knockout mice by both local and systemic immune activation

Chapter 7 Increased basal immune activity renders hypercholesterolemic mice resistant to CMV infection

Chapter 8 General Discussion and Summary

Samenvatting

Dankwoord

Curriculum Vitae

List of publications 



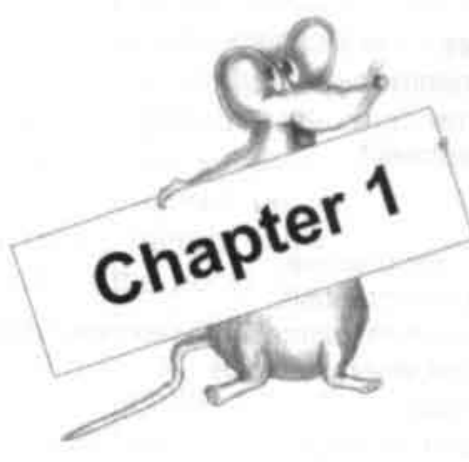

General Introduction 


\section{CHAPTER 1}

1. Preface

2. Cytomegalovirus

2.1. Taxonomy

2.2. Infection-replication

2.3. Epidemiology

2.4. Transmission routes

2.5. Host defense mechanisms

2.6. Escape mechanisms

2.7. Diagnostics and treatment

2.8. Animal models

3. Cytomegalovirus and vascular disease

3.1. Cytomegalovirus and restenosis

3.2. Cytomegalovirus and transplantation-associated arteriosclerosis

3.3. Cytomegalovirus and atherosclerosis

3.3.1. Atherosclerosis

3.3.1.1. Epidemiology

3.3.1.2. Hypotheses of atherogenesis

3.3.1.3. Sequence of events in atherogenesis and lesion classification

3.3.2. Lines of evidence suggesting an association between cytomegalovirus infection and atherosclerosis

3.3.3. Lines of evidence suggesting a contribution of cytomegalovirus infections to atherosclerosis: animal experiments

4. Outline of this thesis 


\section{Preface}

Cardiovascular diseases which are predominantly caused by atherosclerosis remain the leading causes of death in developed countries. Atherosclerosis is considered as a chronic multifactorial inflammatory disease of the large and medium-sized arteries, which develops after endothelial dysfunction caused by mechanical injury, by toxins or by turbulence and low shear stress ${ }^{230}$. Examples of risk factors associated with atherosclerosis are hyperlipidemia, hypertension and smoking history ${ }^{307}$. Recently, epidemiological associations and pathological evidence have suggested that infections (Cytomegalovirus (CMV), Chlamydia pneumonia, Helicobacter pylori) are also associated with this disease ${ }^{51}$. However, it has remained unclear whether these infections really contribute to the disease or are merely "innocent bystanders". The development of animal models has created the possibility of investigating the mechanism by which infections could contribute to atherosclerosis. Since only limited data are available on the mechanism by which CMV contributes to the atherosclerotic process, the effect of CMV infection on atherogenesis was studied in more detail in a mouse model in this thesis.

In this chapter, current knowledge regarding the (patho-)biology of cytomegalovirus is reviewed, as well as existing data on the association of CMV with vascular diseases and particularly atherosclerosis. At the end of this introduction, the outline of this thesis is mentioned. 


\section{Cytomegalovirus}

\subsection{Taxonomy}

As a member of the $\beta$-herpesviruses ${ }^{215,229}, \mathrm{CMV}$ is species-specific with a genome consisting of linear double stranded encapsidated DNA 106, 276. The capsid is surrounded by an amorphous matrix termed 'tegument', that is surrounded by a lipid-bilayer envelope carrying glycoproteins (Fig. 1). The reproduction cycle of the virus is long ( 48 to $72 \mathrm{~h}$ for human CMV (HCMV) and 24 to $36 \mathrm{~h}$ for mouse CMV (MCMV)) ${ }^{106,276}$ and infection induces a characteristic enlargement of the host cell (called "cytomegaly") with obvious nuclear and perinuclear inclusion bodies ${ }^{298}$. After clearance of the primary infection, herpesviruses are known to remain latent with episodes of endogenous reactivation $28,29,65,257,258$. Herpesviruses, like most enveloped viruses, do not survive for long periods outside the body and are predominantly spread by close contact.

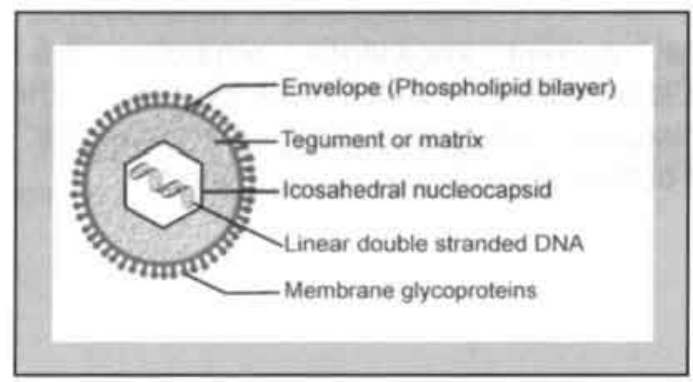

Fig. 1. Schematic drawing of a CMV particle.

\subsection{Infection-replication}

Histopathological analysis shows that virtually every organ can be infected with $\mathrm{CMV}^{183.288}$ given the broad range of target cells for CMV. Major in vivo targets for CMV are epithelial cells, endothelial cells and fibroblasts ${ }^{181}$, 189, 228, 251,303 , but also peripheral blood leukocytes, and parenchymal cells are susceptible to the virus ${ }^{73}, 77,175,233,234,252,253$. As in vivo, a variety of cell culture systems including fibroblasts, endothelial cells, epithelial cells, neuronal cells, smooth muscle cells, macrophages are permissive to CMV in vitro, although at different levels ${ }^{96,105,217,292,296}$. The cell most commonly used to propagate CMV in is the embryonic fibroblast which gives rise to high virus titers.

Infection of permissive cells like fibroblasts starts with the fusion of the virus envelope with the cell surface ${ }^{47}$. After virus internalization, the coat is removed and the DNA is transported to the nucleus. Here viral transcription and replication take place by a complex process of regulatory cascades which can be divided in three phases ${ }^{177}$. The first phase, termed the "immediate early" (IE) phase, does not need de novo protein synthesis ${ }^{169}$, but uses the cell's 
transcription system to produce an overwhelming majority of transcripts from a single locus on the genome ${ }^{41}$. The IE phase encoded proteins predominantly play roles in the activation of the "early" gene expression "177. "Early genes" are responsible for CMV-DNA replication ${ }^{6}$, coding of structural genes and activation of "late genes". "Late genes" encode almost entirely for viral structural antigens like the capsid protein UL86, the tegument protein UL83 and the envelope glycoproteins and for gene products responsible for the assembly, maturation and release of the new virions ${ }^{177}$. The CMV DNA is packaged in the nucleus into preformed capsid particles, which then acquire tegument proteins and become enveloped at the inner nuclear cell membrane ${ }^{174,177}$. Most likely, this primary envelope is lost by fusion with the outer leaflet of the nuclear membrane and final tegumentation occurs in the cytoplasm. Final enveloping occurs by budding into the vesicles of the trans-Golgi network ${ }^{174}$ (Fig. 2).

\subsection{Epidemiology}

CMV is an ubiquitous virus that infects $50 \%$ to $80 \%$ of the normal immunocompetent population and in certain socio-economic and geographic conditions a percentage of nearly $100 \%$ is found ${ }^{25}$. Primary infection occurs most frequently during childhood or adolescence and is associated with mild or subclinical illness ${ }^{25}$. Primary infection of immuno-competent individuals leads only occasionally to clinical symptoms such as mononucleosis syndrome, persistent fever, hepatitis and pneumonia ${ }^{25},{ }^{124}$. The interplay between the host's immune system and viral factors appears to be essential for limiting primary infection. This immunity is sustained for life and maintains the virus in a state of latency. The lifelong persistence of the herpesvirus genome puts the host permanently at risk for recurrent infections. In immuno-compromised patients like transplant recipients or individuals with impaired immunity (for example due to infection with Human Immunodeficiency Virus), recurrence of CMV infection leads to overt manifestations of disease like retinitis ${ }^{182}$, pneumonia ${ }^{1}$, gastrointestinal disease ${ }^{56}$ or hepatitis ${ }^{163}$.

\subsection{Transmission routes}

There are two periods of increased infection occurrence during a life span. The first one is the perinatal period. The second one is during the reproductive ages and is presumably related to sexual activity. Newborns and children become infected in a number of ways. The first way is by passage through a contaminated uterine cervix during birth ${ }^{179}, 263$. A second mechanism is transmission from breast milk ${ }^{93,264}$. A third mechanism of infection is horizontal transmission from other children in the nursery ${ }^{84}$ or in the day care centers ${ }^{203}$ probably via saliva or urine. Two potential sources involved in CMV transmission by sex are the uterine cervix ${ }^{40,44}$ and semen ${ }^{144}$. The frequency of CMV infection of the cervix varies with age, socio-economic class, sexual promiscuity and parity. The presence of CMV in semen has been correlated with younger age of the subject $(<24)$, passive anal sex and large numbers of sexual partners. Other possible viral transmission routes are by blood transfusions ${ }^{114,214}$ or by transplantation of infected organs like kidneys, heart, 


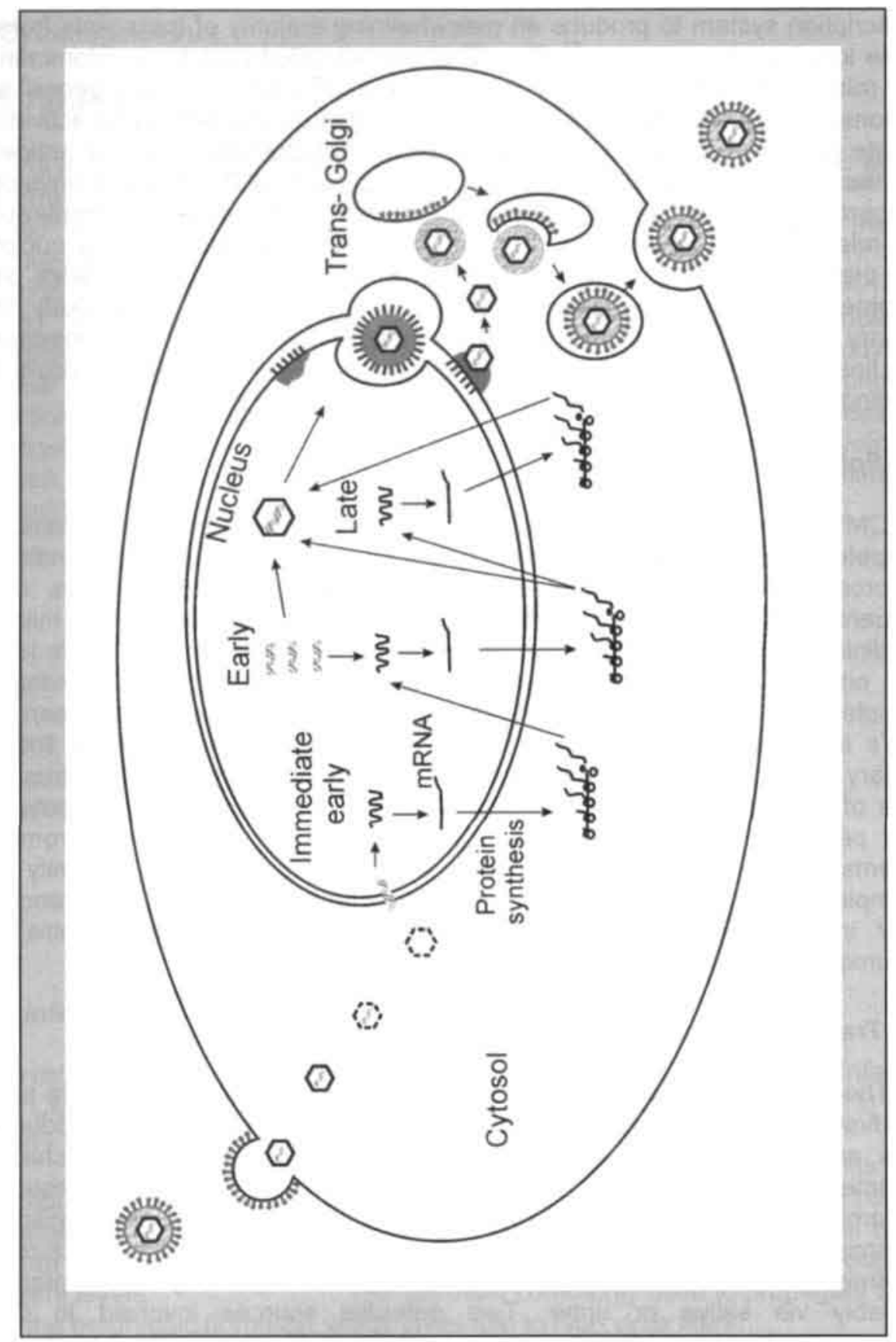

Fig. 2. The replication cycle of CMV (adapted from Mettenleiter, $2002{ }^{174}$ ) 
bone marrow and liver 101, 202, 204, 225. Considering the blood-mediated transmission of HCMV form sero-positive donors to susceptible recipients ${ }^{2,287}$ and the fact that HCMV transmission by blood can be reduced by using leukocyte-depleted blood ${ }^{53,311}$, the virus is most likely present in peripheral blood cells and not as free particles in blood. By sorting peripheral blood populations and using the polymerase chain reaction (PCR), Taylor-Wiedemann et al. showed that monocytes and not polymorphonuclear cells are the major carriers of CMV in the blood ${ }^{282,283}$. Whereas these blood-derived monocytes cannot be productively infected, they become permissive for full replication of CMV upon differentiation to macrophages $105,146,284$. This suggests that monocytes/macrophages serve as vehicles for disseminating CMV into various organs.

\subsection{Host defense mechanisms}

Host defense mechanisms induced after primary infection include both humoral and cellular responses. The cellular immune response consists of Natural Killer (NK) cell, macrophage and antigen-specific T lymphocyte (both $\mathrm{CD}^{+}$and $\mathrm{CD} 8^{+}$) responses ${ }^{21,22,71} \cdot \mathrm{CD}^{+} \mathrm{T}$ cells are the primary effector cells in the clearance of acute CMV infections ${ }^{134,220}$. They recognize peptide epitopes derived from the degradation of cytosolic antigens presented in association with Major Histocompatibility Complex class I (MHC class I) and produce cytokines, like interferon- $\gamma$ (IFN $\gamma$ ) which inhibits CMV replication ${ }^{78,212}$. In addition, CD8 ${ }^{+} \mathrm{T}$ cells lyse virus-infected cells by direct exocytosis of perforins present in cytolytic granules ${ }^{115}$ or by induction of apoptosis in the infected cells ${ }^{109}$. When CD8 $8^{+} \mathrm{T}$ cells are depleted, CMV replication can be controlled by $\mathrm{CD}^{+} \mathrm{T}$ cells ${ }^{113} . \mathrm{CD}^{+}$ $\mathrm{T}$ helper cells recognize endocytosed antigens, presented on MHC class II molecules on activated macrophages. After recognition, the T helper 1 (Th1) subset produces cytokines (including interleukin-2 (IL-2) and IFN $\gamma$ ) and promotes cell-mediated responses while the Th2 subset produces IL-4, IL-5, IL10 thereby promoting humoral responses. The capability of CMV in evading immune surveillance by $\mathrm{CD}^{+} \mathrm{T}$ cells by interfering with $\mathrm{MHC}$ class I molecule expression on the cell surface makes them vulnerable to NK cell-mediated attack (see "CMV escape mechanisms"). NK cells contribute to the control of CMV infection by production of IFN ${ }^{194}$ and by direct cytotoxicity ${ }^{280}$ towards target cells with little or no MHC class I molecules.

The humoral response, which supports the cell-mediated immune response, is thought to be important for the clearance of free virus particles to prevent spread and infection of the virus. In addition, antibodies mediate antibodydependent cellular cytotoxicity and complement activation and enhance phagocytosis of infected cells. After primary CMV infection both immunoglobulin G (IgG) and IgM are produced. The IgM antibody production declines after a period of several weeks to months after primary infection and may recur after reactivation or re-infection. The IgG class antibodies are produced after IgM and production persists for life. Antibodies are produced against almost all components of the virus. Among them are the glycoprotein components of the envelope like glycoprotein $\mathrm{B}(\mathrm{gB})^{24.160}$ and $\mathrm{gH}^{219}{ }^{250}$, virion tegument proteins like pp150 and pp65 ${ }^{94,112}$ and non-structural proteins like pp52 ${ }^{142,143}$, with gB 
and $\mathrm{gH}$ being the major antigens for the neutralizing humoral immune response 186. 293

Although the immune response raised against primary CMV infection consists of both humoral and cellular immune responses, the antibody responses against CMV most likely play only a supportive role since infection is generally cleared before high rate antibody production occurs. This immunity gained against CMV is sustained for life, presumably controlling exogenous and/or endogenous re-infections.

\subsection{Escape mechanisms}

CMV contains weapons to sabotage detection by or activation of the immune system. Sabotage results in latent infection of the host with occasional reactivation phases when the host immune system is weakened. HCMV and MCMV have multiple proteins which interfere with the expression of MHC class I molecules ${ }^{99}$. For example, the m152-encoded $37 / 40 \mathrm{kDa}$ glycoprotein of MCMV transiently interacts with MHC class I and retains class I complexes in the endoplasmic reticulum Golgi intermediate compartment on its journey to the endolysosome. In this way CMV can escape from immunosurveillance by CD8 ${ }^{+}$ $\mathrm{T}$ cells. However, this makes CMV vulnerable to NK cell mediated cytotoxicity ${ }^{161}$. On the other hand, Krmpotic et al. ${ }^{137}$ demonstrated that the same m152encoded $37 / 40 \mathrm{kDa}$ glycoprotein in addition to its effect on MHC class I molecules also appeared to downregulate one of the ligands for the activating NK receptor, hereby overcoming NK activation. In addition, research in mouse genetics has lead to the identification and characterization of a host resistance gene $\mathrm{C} m v 1$ positioned inside the NK gene complex ${ }^{237}$. The alleles of the $\mathrm{Cmv} 1$ locus can be either "susceptible" (Cmv1s, e.g. BALB/c or $129 / \mathrm{J}$ mice) or "resistant" (Cmv1', e.g. C57BL/6J mice). In resistant $\left(\mathrm{Cmv1}^{\prime}\right)$ mice an MCMV encoded MHC-like protein (m157) will bind to an activating NK cell receptor (Ly49H, encoded by the Cmv1 gene) and will allow attack against infected cells ?. In the susceptible mouse strains the Ly49H receptor is lacking (BALB/c) or the $\mathrm{m} 157$ protein will bind to an inhibitory NK cell receptor (Ly49I; 129/J) hereby preventing an NK attack against infected cells and giving the virus the possibility to switch to a state of latency.

CMV can also interfere with $\mathrm{MHC}$ class II antigen-presentation by utilizing IL-10, which plays an essential role in selectively reducing MHC class II expression on the surface of antigen-presenting cells ${ }^{131}$. The virus can either use a viral homologue (cmviL-10) ${ }^{136}$ or stimulate the release of cellular IL-10 from macrophages ${ }^{224}$.

\subsection{Diagnostics and treatment}

To efficiently treat CMV infection, sensitive and specific detection techniques are a necessity. Diagnosis is based on 2 cornerstones: the detection of antibodies against viral antigens and the detection of the virus or parts of the virus (genome or antigens). For clinical diagnostics the detection of active replicating virus is of high priority and is routinely done by virus culture in fibroblasts ${ }^{299}$. When virus particles have entered the cells, a cytopathological effect (CPE), characterized by a swollen phenotype of the infected cells, can be 
seen. Since one may have to wait up to 4 weeks after infection to detect CPE, a directed search for immediate early gene production can already be performed $24 \mathrm{~h}$ post infection by an immunofluorescence technique ${ }^{43}$. The standard method used to detect antibodies against CMV is the enzyme linked immuno sorbent assay (ELISA), which is based on the quantification of antigen-antibody complex formation ${ }^{176}$. With this technique both $\operatorname{lgG}$ and $\operatorname{lgM}$ antibodies can be detected. However, the diagnostic value in the detection of infectious CMV is rather limited ${ }^{216}$. The antigenemia assay (detection of viral proteins in polymorphonuclear cells) ${ }^{77}$ and molecular biological techniques are valuable additions to the diagnostic tools for CMV infections. CMV DNA detection can be done in tissues by in situ hybridization ${ }^{54}$ or in situ polymerase chain reaction (PCR) ${ }^{130}$. In lysates CMV DNA detection can be performed by DNA/RNA hybridization ${ }^{240}$ or $P C R^{238}$. The selection of the method depends primarily on the clinical situation.

CMV infection is currently being treated with antiviral drugs working at the level of DNA replication i.e. ganciclovir ${ }^{68}$, foscarnet ${ }^{45}$ and cidofovir ${ }^{151}$. However, these agents cannot fully clear CMV infection since they don't eliminate latent virus. In addition, drug resistance can occur by mutations in CMV genes ${ }^{42}$. DNA vaccination techniques may overcome these problems and research into the development and evaluation of candidate DNA vaccines against CMV is gradually increasing ${ }^{285}$.

\subsection{Animal models}

To study the CMV-induced pathogenesis and treatment, animal models are indispensable. The animal models which are currently the most widely used in CMV infections are mouse and rat models. The fact that the virus is speciesspecific implicates that respectively MCMV and rat CMV (RCMV) need to be applied for research in these models. An overview of murine CMV in vivo studies performed up until now is summarized in table 1. Viral dissemination followed by the establishment of latency after clearance of primary infection is an important process in CMV-mediated pathogenesis. Therefore, as an example, in fig. 3 a summary is given on internal organs described to harbor MCMV $46,92,120,129,133,140,166,221,271$.

In RCMV studies predominantly Wistar Kyoto, Brown Norway, Dark Agouti, Wistar-Furth and Lewis rats were used. In MCMV studies mostly BALB/c mice were used, since they are described to be the most sensitive mouse strain for MCMV infection ${ }^{153}$. In addition, knockout models (created on a MCMV-resistant C57BL/6J background) are also frequently used to unravel specific aspects of MCMV pathogenesis. C57BL/6J mice deficient in recombinase-activating-gene2 (RAG-2), perforin, granzyme A, granzyme B or combinations thereof have been used to elucidate cytolytic pathways in the host-mediated immune control of MCMV infection ${ }^{227}$. NK deficient Beige mice have been used to specifically study the effect of NK cells on MCMV pathogenesis ${ }^{33}$. Also severe combined immunodeficient (SCID) mice on a BALB/c background and devoid of mature functional T and B lymphocytes have been applied to study MCMV reactivation ${ }^{239}$ and therapy in the absence of the adaptive immune system. Athymic, T cell deficient "nude" mice on a BALB/c background are used to specifically study the impact of T cells on MCMV replication ${ }^{246}$. 


\begin{tabular}{|c|c|c|c|}
\hline Stucy of & & Details & References \\
\hline Latency - persistence - reactivation & $\begin{array}{l}\text { Ceflular localization of latent MCMN } \\
\text {-Relation between conditions of primary } \\
\text {-Persistence } \\
\text { 'Reactivation }\end{array}$ & infection. Latent wial load and reactivation risk & $\begin{array}{l}128,129,210 \\
10,221 \\
139,315 \\
28.31,120,167,239,309.310\end{array}$ \\
\hline Treatment & $\begin{array}{l}\text { Neutralizing antibody transfer } \\
\text { Vaccination } \\
\text {-Antiviral drugs } \\
\text { - Antiviral drug resistance }\end{array}$ & & $\begin{array}{l}8,57,66,110 \\
49,103,165 \\
125,157,188,201,266.268 .297 \\
255\end{array}$ \\
\hline Host dependient CMV sensilintV & $\begin{array}{l}\text { Thvolvement of host } 1 \mathrm{H}-2 \text { genes } \\
\text { 'Involvement of noin } \mathrm{H}-2 \text { genes } \\
\text { 'Effect of cylokines. }\end{array}$ & & $\begin{array}{l}39,80 \\
55,145,153,235-237 \\
72,147\end{array}$ \\
\hline limmune :esponse during Cav intection & $\begin{array}{l}\text { "IFNY als viral defense } \\
\text { "TNFu as viral defence } \\
\text { "NK involvemer!! } \\
\text { 'CDS. T cells } \\
\text { CDE+ T cells } \\
\text { "Macrophages } \\
\text { "Immunodominarl antigens (IE1). }\end{array}$ & 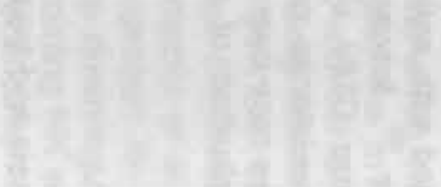 & $\begin{array}{l}26,87,97,211,212,247,281 \\
85,86,156,312 \\
75,135,227,280,294 \\
95,113 \\
220,227,294 \\
3,60,61,88,274 \\
102,222\end{array}$ \\
\hline Nion-immunological mediated host reactions & Nitric oxide-meciated response & & 192.279 \\
\hline Viral escape mechanisms & $\begin{array}{l}\text { MHC class II dewnregulation } \\
\text { MHC class I downregulation }\end{array}$ & & $\begin{array}{l}224 \\
118,137,338,178,302\end{array}$ \\
\hline CMV genes invoived in immune evasion & MHC Ciass I laroeting & 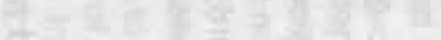 & $14,119,123,126,324$ \\
\hline CMV genes involved in reptication & $\begin{array}{l}\text { "Replication in salivary gland } \\
\text {-Replication in spleen, iver, lung }\end{array}$ & 28 & $\begin{array}{l}\text { 13. } 52,141,152,286 \\
67,117,152,286\end{array}$ \\
\hline Dissemination & Mediated by monocylesimacrophages & ti: & $81,89.277$ \\
\hline Tissue Iropism & $\begin{array}{l}\text { 'Target organs for acute MCMV indection } \\
\text { Target organs for talent MCMV }\end{array}$ & & $\begin{array}{l}\text { 13. 18, 27, 129, 173, 209, } 265 \\
9,14,19,46,166\end{array}$ \\
\hline Pathogenesis & 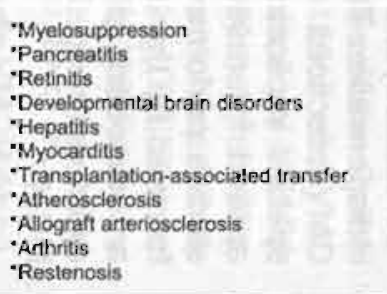 & 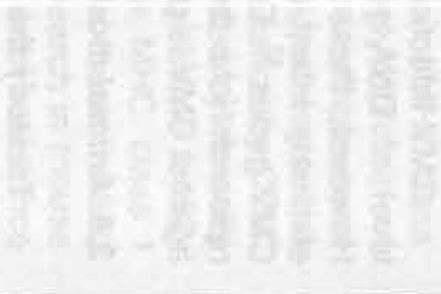 & $\begin{array}{l}74,160 \\
213 \\
69,92,149,150 \\
121,125,132,133,291 \\
38,289 \\
64,148,158,193 \\
23,30,208,245,249,309 \\
35,104,259,260 \\
154,155 \\
79 \\
319\end{array}$ \\
\hline
\end{tabular}




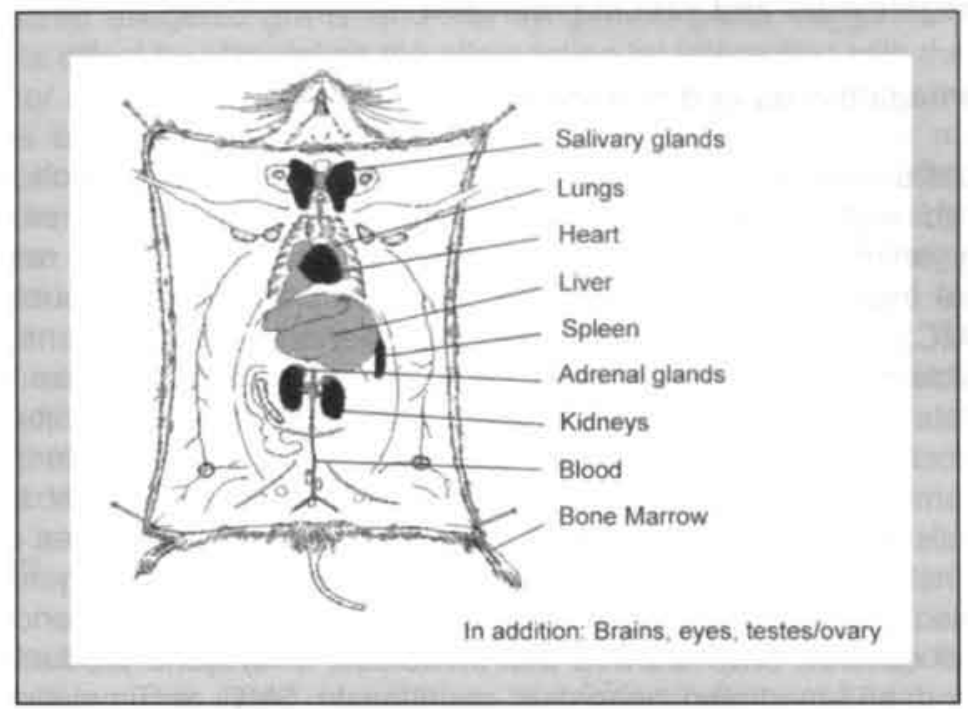

Fig. 3. Overview of CMV tissue tropism. Organs harboring CMV are colored black and gray (figure adapted from http://www.geocities, com/virtualbiology/lymph2.html)

To prevent CMV-mediated pathogenesis, the mechanisms by which $\mathrm{CMV}$ contributes to disease development/progression need to be elucidated. As shown in table 1, the possible role of CMV in diseases like myelosuppression, pancreatitis, retinitis, developmental brain disorders, hepatitis, myocarditis and arthritis has been studied. In addition, CMV has also been described to be associated with vascular diseases like restenosis, transplantation-associated arteriosclerosis (TXAA) and atherosclerosis. Although the processes leading to these vascular pathologies show some similarity, they are not identical. Atherosclerosis is a chronic immune and inflammatory mediated process accompanied by lipid-laden-cell formation and cholesterol deposition and will be discussed in more detail later. Restenosis is a response to endothelial injury, e.g. following balloon dilatation, resulting in rapid ( $<6$ months) occlusion of the lumen by predominantly smooth muscle cell proliferation ${ }^{241}$. TXAA is characterized by the occurrence of a generalized and concentric intimal thickening in all arteries and arterioles of a graft, in contrast with classical atherosclerosis in which the manifestations are focal and asymmetric. Since all three vascular pathologies are life-threatening diseases, the clearance of the CMV-mediated contribution may help to limit death rate. 


\section{Cytomegalovirus and vascular disease}

\subsection{Cytomegalovirus and restenosis}

Endarterectomy or implantation of non-arterial structures such as stents intended to restore the blood flow in vessels occluded by atherosclerosis, frequently results in restenosis. Restenosis is thought to be a response to endothelial injury which goes together with cell proliferation (smooth muscle cells $(\mathrm{SMC})$ ) and extracellular matrix (collagen, proteoglycans, elastin) synthesis/deposition ${ }^{325}$. In a favorable outcome, the healing process reaches a steady state, in other instances intimal growth/adventitial constriction leads to luminal occlusion. The idea of possible involvement of CMV in restenosis initially came from studies demonstrating the presence of CMV in smooth muscle cells from restenotic lesions ${ }^{261}$ and from prospective studies describing a higher risk of restenosis to be associated with CMV infection ${ }^{318}$. In vitro studies also provide evidence that CMV may contribute to restenosis. CMV infection of cultured SMC showed that immediate early gene products of CMV antagonized p53-mediated apoptosis resulting in SMC accumulation ${ }^{278}$ and stimulated vascular SMC resulting in migration and proliferation ${ }^{314,320}$. Ballooninduced carotid artery injury in the rat, mimicking angioplasty-induced injury in the human situation, clearly showed a contribution of CMV to restenosis ${ }^{319}$. CMV infection increased neointimal formation in the rat model without consistent evidence of infectious virus in the vascular wall. This suggests that inflammatory and immune responses directed against CMV account for the vascular response to injury.

\subsection{Cytomegalovirus and transplantation-associated arteriosclerosis}

The most characteristic manifestation in TXAA is an ongoing inflammation and immune response in the graft resulting in neointimal formation, followed by lumen occlusion in all arterioles and arteries of the graft. Risk factors for the disease are histo-incompatibility between donor and recipient ${ }^{48}$, acute rejection periods ${ }^{185}$, hypercholesterolemia ${ }^{58}$, hyperlipidemia ${ }^{305}$, prolonged ischemic time ${ }^{248}$ and CMV infection. Epidemiological reports show HCMV infection to be present at a higher frequency in patients who develop graft rejection ${ }^{11,62,76,116}$ and thereby indicate CMV as a possible factor in TxAA pathogenesis. However, an association does not prove a causal role of the virus in allograft rejection. More direct evidence on the contribution of CMV to TXAA comes from animal studies. The rat aortic transplant model was used to study the effect of RCMV on the development of arteriosclerosis in allogeneic and syngeneic grafts in rats infected early or late after transplantation ${ }^{155}$. Although no effect was seen in the syngeneic grafts or following infection at a later time point after allogeneic transplantation, in rats infected immediately after transplantation an enhanced development of TXAA in the allograft was observed. At 7 days post infection an influx of monocytes/ macrophages and T lymphocytes was seen in the adventitia of the allograft. This was followed by subendothelial mononuclear cell infiltration at 1 month after infection. Similar results were observed by Bruning et al. ${ }^{32}$ and $\mathrm{Li}$ et al. ${ }^{159}$, who used Brown Norway and Lewis rat combinations instead of Dark Agouti and Wistar-Furth combinations. The fact that RCMV only 
affected aortic allogenic grafts and not syngeneic grafts suggests that CMV mediates its effect by stimulating the alloreaction by interacting with the immune system after aortic transplantation. This suggestion is supported by the work of Hillebrands et al. ${ }^{100}$, who investigated the development of TxAA after aortic transplantation in different rat strain combinations. Similar effects were observed in RCMV-infected cardiac allografts ${ }^{154}$ which showed enhanced perivascular influx of T cells, NK cells and monocytes/macrophages in the infected animals. In RCMV-infected lung transplants, an increased expression of adhesion molecules in the allografts was found ${ }^{273}$. In summary, CMV plays an important role in the development of arteriosclerosis after solid organ transplantation. Although the mechanism is not fully understood, most data suggest that infection stimulates the alloreaction leading to enhanced arteriosclerosis.

\subsection{Cytomegalovirus and atherosclerosis}

In addition to its effect on restenosis and TXAA, CMV is also associated with atherosclerosis. The initial suggestion that infections might play a role in atherogenesis was made by Sir William Osler in the beginning of the previous century 195 by listing four provocative factors as potential causes for arteriosclerosis. These are the wear and tear of life, acute infections (especially syphilis, salmonella, tuberculosis and other agents), intoxications (including smoking, diabetes and obesity) and circumstances that keep the blood tension high. Hereafter the hypothesis received only minor attention until Fabricant et al. demonstrated that chickens infected with an avian herpesvirus called Marek's disease virus, developed atherosclerotic-like changes in the vascular wall ${ }^{63}$. These findings in addition to the inability to explain the total etiology and pathogenesis of the atherosclerotic disease by means of the classical risk factors (see the following paragraphs), prompted researchers to study the possible contribution of common chronic infections to atherogenesis. Up until now, a whole range of infections are considered to contribute to atherosclerosis, with the most studied being Chlamydia pneumoniae, Helicobacter pylori, herpes simplex virus, hepatitis A virus and CMV 82, 171, 172, 295, 321. Recently the "pathogen burden hypothesis" has been proffered by Zhu et al. ${ }^{322 .}{ }^{323}$. This hypothesis suggests that the risk for coronary artery disease, myocardial infarction and death is related to the number of different pathogens to which an individual has been exposed. In summary, evidence is accumulating that infections most probably play a role in the atherosclerotic process and that the number of (different) infections to which an individual has been exposed has also an impact.

In the case of CMV, various lines of evidence demonstrate an association between CMV and atherosclerosis. However, before reviewing these lines of evidence in following paragraphs an overview on atherosclerosis is presented in an attempt to facilitate the reading of the sections describing the mechanisms by which $\mathrm{CMV}$ might contribute to the disease. 


\subsubsection{Atherosclerosis}

\subsubsection{Epidemiology}

Atherosclerosis is a chronic inflammatory disease of the medium-sized and large arteries. In childhood the disease is usually limited to its early stages and is not evident. Nonetheless, clinical events resulting from atherosclerosis, like stroke and heart attack, are the leading causes of disability and death from middle age onwards. Established risk factors associated with cardiovascular disease include family history, smoking history, hypertension, elevated serum cholesterol levels, diabetes, increasing age, excessive alcohol consumption, physical inactivity and male sex ${ }^{307}$. The multifactorial etiology of atherosclerosis and the contribution of all of these factors to the risk of developing a future clinical event are of great importance. For a proper assessment of disease risk in an individual, the presence or absence and degree of severity of each individual risk factor has to be considered, and in addition, the potential impact of modifiable (environmental) risk factors has to be weighed against the nonmodifiable (genetic) risk factors of each individual.

\subsubsection{Hypotheses of atherogenesis}

At least 4 hypotheses have been proposed to explain the origins of atherosclerosis. The "monoclonal hypothesis" ${ }^{242}$, focusing on SMC proliferation, was originally derived from observations that (1) the fibrous cap of the atherosclerotic plaques is mainly composed of SMC and (2) that SMC appear to migrate from the underlying media to the intima with consequent proliferation. Therefore, lesions were regarded as being aberrations of growth control.

Another proposition for atherosclerosis is the "response to altered lipoprotein hypothesis" 111, 272. The hypothesis postulates that native Low Density Lipoproteins (LDL) are chemically modified after accumulation in the subendothelial layer. The diminished efflux of the chemically modified LDL is realized by foam cell formation by macrophages and SMC with subsequent lesion progression ("response-to-retention hypothesis" of Williams et al. ${ }^{304}$ ).

One of the major classic concepts concerning atherosclerosis was postulated by Russell Ross ("response to injury hypothesis") ${ }^{230}$. He hypothesized that atherosclerosis starts following endothelial dysfunction caused by mechanical injury, low shear stress, toxins, oxygen radicals and other factors. As a consequence of this endothelial injury, vascular wall permeability increases and endothelial cells express adhesion molecules, release growth factors and release chemotactic factors. Leukocytes then migrate to the subendothelial layer where they meet the SMC migrating from the media followed by the formation of lipid-laden SMC and macrophages with the subsequent development of atherosclerotic lesions.

As it has been shown that atherosclerotic lesions are rich in immune/inflammatory cells (predominantly macrophages and T lymphocytes), Hansson et al. postulated atherosclerosis to be an immune-mediated disease 90. Recent studies in experimental gene-targeted mice have provided mechanistic evidence for this hypothesis $59,83,164$. Immune mechanisms in atherosclerosis include the recruitment of leukocytes to the vascular wall after 
endothelium activation, subsequent macrophage secretion of oxygen radicals, proteases, cytokines and complement factors and macrophage-mediated scavenging and presentation of antigens. By presenting antigens, macrophages activate $T$ cells, which either mediate cytotoxic activity against cells that express proteosomally processed peptides ( $T$ cytotoxic cells) or secrete cytokines ( $T$ helper cells). These events ultimately result in a cascade of immunological events accelerating disease progression. Oxidized LDL (oxLDL), heat shock proteins (HSPs), bacteria and viral antigens are all described to be candidate antigens in atherosclerosis $90,91,190$. OxLDL has been described as an autoantigen (i.e. endogenous antigen) formed in the lesions by chemical modification of LDL. It elicits both local and humoral immune responses which may contribute to atherosclerosis progression ${ }^{199,200,275,313}$. HSPs are induced after stress conditions in prokaryotic and eukaryotic cells to fulfill important functions in folding and intracellular transport of proteins. Furthermore, they exert a chaperone function to protect proteins against denaturation. HSPs are classified in different groups based on their molecular mass and demonstrate a high degree of sequence homology between phylogenic families, e.g. mycobacterial HSP65, chlamydial HSP60 and Escherichia coli HSP60 show a homology of over $90 \%$ at both the DNA and protein level. In addition, HSP60s are also highly conserved between human and bacterial species. Since humans are regularly infected with microorganisms during their lifetime, cross-reactivity of anti-pathogen HSP60 formed antibodies and self-HSPs (called "molecular mimicry") can frequently occur. Thus, the protective immune response directed against foreign HSP60, may increase the risk for autoimmune reactions that damage host cells eventually leading to induction/aggravation of atherosclerosis 300, 301. The exact mechanism by which viral and bacterial antigens contribute to the atherosclerotic process remains to be clarified but a review of findings concerning the contribution of $\mathrm{CMV}$ to atherosclerosis is given later.

The exact underlying mechanisms of atherogenesis may be a combination of all the hypotheses mentioned above. Although lesions were initially regarded as the result of aberrations of vascular smooth muscle cell growth and LDL retention in the subendothelial layer by chemical modification, atherosclerosis is nowadays deemed as being a complex disease involving immune and inflammatory cascades induced after endothelial dysfunction leading to SMC proliferation and migration, in addition to LDL retention in SMC and macrophages.

\subsubsection{Sequence of events in atherogenesis and lesion classification}

The most common way to categorize atherosclerotic lesions is based on The American Heart Association Classification as described by Stary et al. ${ }^{269}$. ${ }^{270}$. Lesion types are designated by Roman numerals and consist of type I to type VI lesions in humans (Table 2). Representative histological sections of mice lesions belonging to each type (except type VI) are shown in chapter 2 . Lipid-laden macrophages are the pathological hallmarks of type I and type II lesions. At arterial branches and curvatures with alterations in the blood flow (e.g. decreased shear stress and high turbulence), endothelial cells will express adhesion molecules. This results in monocyte adherence and $\mathrm{T}$ lymphocyte trapping with subsequent migration and accumulation into the subendothelial 
Table 2. American Heart Association Lesion Classification.

\begin{tabular}{|c|c|c|c|}
\hline $\begin{array}{c}\text { Lesion } \\
\text { type }\end{array}$ & Description & Alternative classification \\
\hline Type I & $\begin{array}{c}\text { Presence of lipid-laden } \\
\text { macrophages in the media }\end{array}$ & Initial lesion & \\
Type II & $\begin{array}{c}\text { Lipid-laden macrophage layers in the } \\
\text { lumen }\end{array}$ & Fatty streak & Early lesions \\
Type III & $\begin{array}{c}\text { Type II lesions with small } \\
\text { extracellular lipid droplets }\end{array}$ & Intermediate lesion & \\
\hline Type IV & $\begin{array}{c}\text { Type II lesions with lipid core and } \\
\text { possible fibrous cap formation at the } \\
\text { shoulder region }\end{array}$ & Atheroma & \\
\hline Type V & $\begin{array}{c}\text { Type IV lesion with fibrous cap } \\
\text { covering the entire lesion and } \\
\text { possible calcifications }\end{array}$ & Fibroatheroma & Advanced \\
\hline lesions
\end{tabular}

space ${ }^{231}$. Lipoproteins may be entrapped in the human intima by matrix components ${ }^{243.262}$ where they become modified ${ }^{205}$. Modified lipoproteins are taken up by macrophages by scavenger receptor pathways to form the socalled "foam cells". After lysis of the foam cells, cholesteryl-ester rich droplets will be produced, forming type III lesions. These droplets in addition to cell debris can be re-uptaken by neighboring macrophages, which can also lyse, eventually leaving large lipid cores and forming type IV lesions. SMC will be attracted from the media to the intima and proliferate as a result of binding of PDGF (platelet derived growth factor) to receptors on these SMC ${ }^{218}$, In addition to macrophages, intimal SMC will remove deposited lipoproteins and form foam cells ${ }^{17}$. These lesions with the predominant component being the SMC are type $\checkmark$ lesions as described by Stary's classification. Type $V$ lesions can be further subdivided in type $\mathrm{Va}$ lesions showing a mixed composition of fibrous tissue and lipids, type $\mathrm{Vb}$ lesions showing a prominent calcific component and type $\mathrm{Vc}$ lesions showing a prominent fibrous component. Type IV or type V lesions with disruptions of the lesion surface, hemorrhages or thrombotic deposits are called type $\mathrm{VI}$ lesions and are largely responsible for morbidity and mortality from atherosclerosis. A variety of mechanisms have been proposed by which these symptomatic type VI lesions are formed. Plaques can get invaded by a fragile network of capillaries derived from the vasa vasorum in the adventitia ${ }^{12}$. These newly formed blood vessels might lead to intraplaque hemorrhage with subsequent increase in lesion size, occlusion of the lumen and subsequent development of symptoms. Otherwise lumen occlusion can occur by thrombus formation after plaque rupture, caused by weakening of the fibrous cap by diminished extracellular matrix or SMC content. Atherosclerotic plaques are particularly weakened at the height of the fibrous cap where macrophage and $T$ lymphocyte content are high in the lesion. The enhanced destruction of 
extracellular matrix by the release of proteolytic enzymes (matrix metalloproteinases) by macrophages ${ }^{244}$ and the decreased extracellular matrix synthesis by cytokine synthesis may cause these ruptures ${ }^{5}$. Apoptosis of vascular smooth muscle cells is governed by cell-cell, cell-matrix and cellcytokine interactions. Macrophages and $T$ lymphocytes possibly mediate vascular SMC apoptosis by NO (nitric oxide) induction of p53 and Fas and via TNF $\alpha$-mediated apoptosis, but also by T lymphocyte mediated Granzyme B expression ${ }^{15}$. Apoptosis of endothelial cells influenced by local low shear stress at the downstream parts of the plaque leads to exposure of the subendothelium to blood flow and promotes platelet aggregation and thrombus formation ${ }^{290}$. Finally, plaque stability is correlated with lipid core size. The inability of the soft lipid core to bear large mechanical stresses that may develop during elevated blood pressure makes stresses concentrate in the fibrous cap, particularly at the edges, thereby leading to rupture ${ }^{162}$.

\subsubsection{Lines of evidence suggesting an association between CMV infection and atherosclerosis}

Three major lines of evidence suggest an association between CMV and atherosclerosis: sero-epidemiological studies, detection of the virus in atherosclerotic lesions and in vitro experiments.

A large number of sero-epidemiological studies, summarized by Danesh et al., illustrate a positive correlation between CMV antibodies and cardiovascular disease ${ }^{51}$. However, although indicative for a contribution of CMV to cardiovascular disease, the observed positive correlations in these studies are weakened by the fact that small sample size, incomplete confounder adjustments and exploratory statistics were applied. Furthermore, few studies were of native atherosclerosis and focused on TxAA and restenosis. The prospective, well-controlled nested case-control study performed by Ridker et al. ${ }^{226}$ to determine the impact of CMV on native atherosclerosis, showed CMV antibody presence not to be associated with atherothrombotic risk. However, they focused on baseline prevalence of CMV antibodies and did not take the height of anti-CMV antibodies in account. The ARIC (Atherosclerosis Risk in Communities) study indicated this to be a crucial factor in demonstrating an association of CMV with atherosclerosis ${ }^{191}$. This study showed the level of CMV antibodies to be gradually related to increased intimal-medial thickening. Similar observations were made by Gattone et al. ${ }^{70}$ and Blum et al. ${ }^{19}$, demonstrating high but not low anti-CMV antibody levels to be associated with coronary artery disease and myocardial infarction, implicating that seroepidemiological association studies have to take the height of CMV antibody titers into account.

The first paper describing CMV to be present in the vascular wall came from Melnick et al. ${ }^{170} \mathrm{CMV}$ antigens were stained by immunofluorescent antibodies and were shown to be present in SMC cultured from atherosclerotic plaque samples, suggesting a role for $\mathrm{CMV}$ in the pathogenesis of atherosclerosis. Later, the presence of CMV in cells cultured from human arterial tissue was confirmed by in situ hybridization techniques ${ }^{206}$. The finding that CMV DNA, as detected by PCR analysis, was present in $90 \%$ of the arterial walls of 
atherosclerotic patients and only in $50 \%$ of the persons in the control group, also supported a role for $\mathrm{CMV}$ in atherogenesis ${ }^{98}$.

In vitro experiments revealed that CMV modulates cellular gene products involved in the pathobiology of atherosclerosis. CMV-mediated up-regulation of the scavenger receptor class A on SMC was associated with an increased uptake of oxLDL ${ }^{31}$. As increased oxLDL uptake plays an important role in atherogenesis, the observed results provide further evidence for a possible role of CMV in the disease. In addition, SMC infection was shown to induce upregulation of PDGF receptors and may hereby increase SMC migration and proliferation in atherosclerotic lesions ${ }^{320}$. Also, up-regulation of adhesion molecules on infected endothelial cells may permit facilitated adhesion of monocytes ${ }^{127}$. Furthermore, CMV induced cytokine production due to infection of the cell itself or to its interaction with other cells like leukocytes ${ }^{4,256,308}$ may be important in atherosclerosis progression.

Although these three lines of evidence strongly suggest an involvement of $\mathrm{CMV}$ in atherosclerosis, they do not unequivocally confirm the role or the mechanisms by which CMV contributes to atherogenesis. On the other hand, the possibility of using animal models has created the possibility for wellcontrolled studies to clarify the issue of CMV causality in atherosclerotic disease.

\subsubsection{Lines of evidence suggesting a contribution of CMV infections to atherosclerosis: animal experiments}

The etiology of atherosclerosis is complex. Many different genes, including those related to lipid metabolism, affect its development and the disease is greatly influenced by environmental factors. In addition, the disease can only be reproduced in living animals thereby largely eliminating the use of in vitro models to study the disease. These facts strengthen the need for laboratory animals to study the atherosclerotic process under well-controlled conditions.

Infection experiments in rats (characterized as atherosclerosis resistant) showed CMV to enhance leukocyte adhesion to the endothelial layer and lipid accumulation in the subendothelium. This phenomenon was even more pronounced in rats fed a high cholesterol diet ${ }^{259}$.

Irradiated BALB/c mice, also characterized as being atherosclerosisinsensitive ${ }^{196}$, showed the accumulation of inflammatory cells in the aortic lumen after CMV infection. Furthermore, the percentage of LDL-cholesterol was seen to be significantly increased in the serum of infected mice, whether or not they were fed a high cholesterol diet ${ }^{16}$. A similar experiment performed in these mice again demonstrated the presence of inflammatory foci in the vascular wall and showed that some of these foci develop into atherosclerotic lesions ${ }^{34}$.

C57BL/6J mouse strains can be used as a model for studies of high fat dietinduced atherosclerosis ${ }^{197,198}$. However, atherosclerosis in these mice is rather limited and mainly restricted to the aortic sinus. In 1992, Breslow's and Maeda's laboratories independently reported that mice deficient in apolipoprotein E (apoE), a ligand important in lipoprotein uptake, had elevated plasma cholesterol levels and spontaneously developed severe atherosclerosis even on a low-cholesterol diet ${ }^{84,207,316}$. Since lesion progression and localization in these mice is similar to human atherogenesis, they have become a powerful 
tool in atherosclerosis research ${ }^{184 .}{ }^{223}$. Lesion size and progression can be aggravated and accelerated by feeding apoE knockout $\left(a p o E^{-1}\right)$ mice a highcholesterol diet ${ }^{184,207}$. An alternative mouse model sensitive to atherosclerosis development, is the LDL receptor knockout (LDLrec ${ }^{-1}$ ) mouse ${ }^{107}$. Although these mice show elevated levels of LDL, they fail to develop atherosclerosis when put on a chow diet. When challenged with a high cholesterol diet, they develop atherosclerosis throughout the aorta ${ }^{108}$. However, it is generally accepted that apoE $\mathrm{E}^{-\%}$ mice, even when fed a chow diet, exhibit more severe and complex lesions than LDLrec ${ }^{-1}$ mice even when these mice are fed a high cholesterol diet and develop higher cholesterol levels ${ }^{254}$. In addition, homozygous apoE/LDLrec double knockouts can also be used to study atherosclerosis. Lesion progression goes remarkably faster in these mice than in single knockouts and they do not need to be fed a cholesterol-enhanced diet to develop severe atherosclerotic disease ${ }^{20}$. The development of these transgenic mouse strains has created the possibility to study the effect of CMV on the progression of atherogenesis. However, in contrast with the frequent use of these mice to clarify atherogenesis in general ${ }^{36,37,50,122,168,306}$, only a limited number of papers is published dealing with the CMV-mediated contribution to atherogenesis. ApoE mice infected at 2 weeks of age showed increased lesion area at 14 weeks post infection when compared with mock infected mice, indicating that $\mathrm{CMV}$ contributes to lesion progression ${ }^{35,104}$. The demonstration of increased serum IFN $\gamma$ levels at 4 weeks post infection indicates that a systemic immune response to infection contributes to the infection-associated increase in lesion size. In contrast, Rott et al. ${ }^{232}$ showed CMV infection not to influence lesion size, when 8-week-old apo $\mathrm{E}^{/-}$mice were infected and sacrificed 3 weeks later. The difference between these publications has been attributed to the difference in time between infection and sacrifice and the difference in age at infection. Since 2-week-old mice do not have a yet fully evolved immune response, it may be speculated that these mice react differently to infections than adult mice.

In conclusion, the studies described above show that CMV might contribute to both initiation and progression of atherosclerosis and that the virus is more than just an "innocent bystander".

\section{Outline of this thesis}

Although evidence is accumulating that CMV contributes to the atherosclerotic disease, data are too scarce to clarify the mechanism by which the virus is a factor in disease development. It may be hypothesized that the effects of CMV-accelerated disease development depend on local mechanisms in the vascular wall requiring the presence of the virus inside the artery. On the other hand, systemic activation of the immune system with subsequent production of pro-atherogenic cytokines/chemokines following infection may provide an alternative mechanism by which CMV contributes to atherosclerosis. The main objective of the present thesis was to unravel the mechanisms by which CMV accelerates the formation of atherosclerotic plaques, either by direct or by indirect mechanisms. 
In a first study (chapter 2) we evaluated the effect of MCMV infection on atherosclerosis progression in two mouse models (C57BL/6J on a highcholesterol diet and $\mathrm{apoE}^{-}$) in which the initial stages of atherosclerosis were present at the time of infection. Lesion area, lesion composition, inflammatory influx in lesions and plasma lipid profiles were investigated.

To mediate a direct effect on atherosclerosis, the presence of the virus may be required in the vascular wall. One of the most abundantly used techniques to detect viral DNA in tissues is the PCR technique. Nonetheless, as the virus may only be present in the vascular wall in low amounts an ultra-sensitive PCR method is essential. In chapter $\mathbf{3}$ we describe the development of a PCR technique for MCMV detection, which is both very sensitive, and also quantitative (real-time PCR). This technique allows us to determine the exact number of viral DNA copies in various organs (including the vascular wall) at specific time points post infection. In chapter $\mathbf{4}$ we used this technique to evaluate the presence of $\mathrm{CMV}$ in the vascular wall of apoE $\mathrm{E}^{-/}$mice following single and multiple low-dose MCMV infection. Multiple low-dose infections were used to mimic chronic latent infection with recurrent intervals of viral shedding and we studied the effect of these low dose infections on atherosclerosis. In addition we assessed the effect of UV-inactivated MCMV injections on plaque formation. As MCMV antigen injection results in activation of the immune system without viral replication, an effect of these injections on atherosclerosis may suggest that the effect of MCMV infection is at least partly mediated by an indirect effect.

Macrophages are well recognized to play an important role in plaque development, e.g. by the production of various pro-inflammatory and proatherogenic cytokines. Also, infections stimulate the production of cytokines by macrophages. This, however, depends on macrophage phenotype. In chapter 5 , the effect of MCMV infection on macrophage differentiation was studied. Therefore peritoneal macrophages were isolated from MCMV-infected apoE mice and phenotyped.

In chapter 6 we extended the work described earlier in chapter 2 aiming to better understand the mechanisms underlying the MCMV effects on atherosclerosis. In this study we focused on local as well as systemic effects of MCMV infection. Here we used an ultra-sensitive although non-quantitative PCR method to detect MCMV DNA in the vascular wall and examined both local and systemic production of pro-inflammatory cytokines (TNF $\alpha$ and IFN $\gamma$ ) in $\mathrm{apoE}^{-}$mice following MCMV infection.

It is well known that C57BL/6 mice (the background strain of the apoE ${ }^{-1}$ mice) are relatively resistant to MCMV infection. On the other hand, hypercholesterolemic mice (apoE ${ }^{-1}$ and $\mathrm{LDLrec}^{-1}$ ) fail to rapidly clear bacterial infections, indicating that hypercholesterolemia may exert negative effects on general immune responses. In addition, hypercholesterolemia may suppress antiviral immune responses, rendering $\mathrm{apoE}^{-1-}$ and $\mathrm{LDLrec}^{-1-}$ mice more susceptible to viral infections. In chapter 7 , both atherosclerosis-sensitive mouse types are studied with respect to MCMV sensitivity and various aspects in the activation of the immune system following MCMV infection.

Finally, data obtained in the different studies in this thesis are discussed in chapter $\mathbf{8}$ in relation to the general hypothesis that CMV contributes to the progression of the atherosclerosis. 


\section{REFERENCES}

1. Abdallah PS, Mark JB, Merigan TC. Diagnosis of cytomegalovirus pneumonia in compromised hosts. Am J Med. 1976;61:326-332.

2. Adler SP. Transfusion-associated cytomegalovirus infections. Rev Infect Dis. 1983;5:977-993.

3. Allcock RJ, Peacock $C D$. Price $P$. The inflammatory macrophage response to $M C M V$ in mice with a retroviral immunodeficiency syndrome (MAIDS). J Leukoc Biol. 1996;60:44-50.

4. Almeida GD, Porada $C D$, St Jeor $S$, Ascensao JL. Human cytomegalovirus alters interleukin-6 production by endothelial cells. Blood. 1994:83:370-376.

5. Amento EP, Ehsani N, Palmer H, Libby P. Cytokines and growth factors positively and negatively regulate interstitial collagen gene expression in human vascular smooth muscle cells. Arterioscler Thromb. 1991;11:1223-1230.

6. Anders DG, McCue LA. The human cytomegalovirus genes and proteins required for DNA synthesis. Intervirology. 1996;39:378-388.

7. Arase $\mathrm{H}$, Mocarski ES, Campbell AE, Hill AB, Lanier LL. Direct recognition of cytomegalovirus by activating and inhibitory NK cell receptors. Science. 2002;296:1323-1326.

8. Arizono H, Ishii S, Nagao T, Kudo S, Sasaki S, Kondo S, Kiyoki M. Pharmacokinetics of a new human monoclonal antibody against cytomegalovirus. First communication: plasma concentration, distribution, metabolism and excretion of the new monoclonal antibody, regavirumab after intravenous administration in rats and rabbits. Arzneimittelforschung. 1994:44:890-898.

9. Balthesen $M$, Messerle $M$, Reddehase MJ. Lungs are a major organ site of cytomegalovirus latency and recurrence. J Virol. 1993;67:5360-5366.

10. Balthesen M, Dreher L, Lucin P, Reddehase MJ. The establishment of cytomegalovirus latency in organs is not linked to local virus production during primary infection. J Gen Virol. 1994:75:2329-2336.

11. Bando K, Paradis IL, Komatsu K, Konishi H, Matsushima M, Keena RJ, Hardesty RL, Armitage $J_{M}$, Griffith BP. Analysis of time-dependent risks for infection, rejection, and death after pulmonary transplantation. J Thorac Cardiovasc Surg. 1995;109:49-57; discussion 57-49.

12. Barger AC, Beeuwkes R, 3rd. Rupture of coronary vasa vasorum as a trigger of acute myocardial infarction. Am J Cardiol. 1990;66:41G-43G.

13. Beisser PS, Vink C, Van Dam JG, Grauls G, Vanherle SJ, Bruggeman CA. The R33 G proteincoupled receptor gene of rat cytomegalovirus plays an essential role in the pathogenesis of viral infection. J Virol. 1998;72:2352-2363.

14. Beisser PS, Kloover JS, Grauls GE, Blok MJ, Bruggeman CA, Vink C. The r144 major histocompatibility complex class I-like gene of rat cytomegalovirus is dispensable for both acute and long-term infection in the immunocompromised host. J Virol. 2000;74:1045-1050.

15. Bennett MR. Apoptosis of vascular smooth muscle cells in vascular remodelling and atherosclerotic plaque rupture. Cardiovasc Res. 1999;41:361-368.

16. Berencsi K, Endresz V, Klurfeld D, Kari L, Kritchevsky D, Gonczol E. Early atherosclerotic plaques in the aorta following cytomegalovirus infection of mice. Cell Adhes Commun. 1998:5:39-47.

17. Bierman EL, Albers JJ. Lipoprotein uptake and degradation by cultured human arterial smooth muscle cells. Adv Exp Med Biol. 1976;67:437-452.

18. Blok MJ, Savelkouls KGM, Grauls GELM, Bruggeman CA. Vink C. Immediate early-1 mRNA expression and virus production are restricted during the acute phase of rat cytomegalovirus infection in immunocompetent rats. In: Blok MJ, ed. Monitoring the course of CMV infection by detection of specific viral transcripts: Thesis University Maastricht; 2001: 91-124 (ISBN 909015374-8)

19. Blum A, Giladi M, Weinberg M, Kaplan G, Pasternack $H$, Laniado S, Miller H. High anticytomegalovirus (CMV) IgG antibody titer is associated with coronary artery disease and may predict post-coronary balloon angioplasty restenosis. Am J Cardiol. 1998:81:866-868.

20. Bonthu S. Heistad DD, Chappell DA, Lamping KG. Faraci FM. Atherosclerosis, vascular remodeling, and impairment of endothelium-dependent relaxation in genetically altered hyperlipidemic mice. Arterioscler Thromb Vasc Biol. 1997:17:2333-2340.

21. Borysiewicz LK, Rodgers B, Morris S, Graham S, Sissons JG. Lysis of human cytomegalovirus infected fibroblasts by natural killer cells: demonstration of an interferon-independent component requiring expression of early viral proteins and characterization of effector cells. $J$ Immunol. 1985;134:2695-2701. 
22. Borysiewicz LK, Hickling JK, Graham S, Sinclair J, Cranage MP, Smith GL, Sissons JG. Human cytomegalovirus-specific cytotoxic $T$ cells. Relative frequency of stage-specific CTL recognizing the $72-\mathrm{kD}$ immediate early protein and glycoprotein $\mathrm{B}$ expressed by recombinant vaccinia viruses. J Exp Med. 1988;168:919-931.

23. Bos GM, Majoor GD, Bruggeman CA, Grauls G, van de Gaar MJ, van Breda Vriesman PJ. Rat cytomegalovirus can be transferred by bone marrow cells but does not affect the course of acute graft-versus-host disease. Transplant Proc. 1989;21:3050-3052.

24. Britt WJ, Vugler L, Butfiloski EJ, Stephens EB. Cell surface expression of human cytornegalovirus (HCMV) gp55-116 (gB): use of HCMV-recombinant vaccinia virus-infected cells in analysis of the human neutralizing antibody response. J Virol. 1990;64:1079-1085.

25. Britt WJ, Alford CA. Cytomegalovirus. In: Fields BN, Knipe DM, Howley PM, eds. Fields Virology. Philadelphia: Lippencott-Raven Publishers; 1996: 2493-2523.

26. Bruggeman CA, Schellekens H, Grauls G, Debie WM, van Boven CP. Rat cytomegalovirus: induction of and sensitivity to interferon. Antiviral Res. 1983:3:315-324.

27. Bruggeman CA, Meijer H, Bosman F, van Boven CP. Biology of rat cytomegalovirus infection. Intervirology. 1985;24:1-9.

28. Bruggeman CA. Reactivation of latent CMV in the rat. Transplant Proc. 1991;23:22-24, discussion 24.

29. Bruggeman CA. Cytomegalovirus and latency: an overview. Virchows Arch B Cell Pathol Incl Mol Pathol. 1993:64:325-333.

30. Bruning $\mathrm{JH}$, Bruggeman $\mathrm{CA}$, van Boven $\mathrm{CP}$, van Breda Vriesman PJ. Passive transfer of cytomegalovirus by cardiac and renal organ transplants in a rat model. Transplantation. 1986;41:695-698.

31. Bruning $\mathrm{JH}$, Bruggeman $\mathrm{CA}$, van Boven $\mathrm{CP}$, van Breda Vriesman PJ. Reactivation of latent rat cytomegalovirus by a combination of immunosuppression and administration of allogeneic immunocompetent cells. Transplantation. 1989;47:917-918.

32. Bruning JH, Persoons M, Lemstrom K, Stals FS, De Clercq E, Bruggeman CA. Enhancement of transplantation-associated atherosclerosis by CMV, which can be prevented by antiviral therapy in the form of HPMPC. Transpl Int. 1994;7 Suppl 1:S365-370.

33. Bukowski JF, Woda BA, Welsh RM. Pathogenesis of murine cytomegalovirus infection in natural killer cell-depleted mice. J Virol. 1984;52:119-128.

34. Burian K, Berencsi K, Endresz V, Gyulai Z, Valyi-Nagy T, Valyi-Nagy I, Bakay M, Geng Y, Virok D. Kari L. Hajnal-Papp R, Trinchieri G, Gonczol E. Chlamydia pneumoniae exacerbates aortic inflammatory foci caused by murine cytomegalovirus infection in normocholesterolemic mice. Clin Diagn Lab Immunol. 2001;8:1263-1266.

35. Burnett MS, Gaydos CA, Madico GE, Glad SM, Paigen B, Quinn TC, Epstein SE. Atherosclerosis in apoE knockout mice infected with multiple pathogens. $J$ Infect Dis. 2001:183:226-231.

36. Caligiuri G, Nicoletti A, Zhou XH, Tornberg I, Hansson GK. Effects of sex and age on atherosclerosis and autoimmunity in apoE-deficient mice. Atherosclerosis. 1999:145:301-308.

37. Caligiuri G, Rudling M, Ollivier V, Jacob MP, Michel JB, Hansson GK, Nicoletti A. Interleukin10 deficiency increases atherosclerosis, thrombosis, and low-density lipoproteins in apolipoprotein E knockout mice. Mol Med. 2003;9:10-17.

38. Cassell HS, Price P. Olver SD, Yeoh GC. The association between murine cytomegalovirus induced hepatitis and the accumulation of oval cells. Int J Exp Pathol. 1998;79:433-441.

39. Chalmer JE, Mackenzie JS, Stanley NF. Resistance to murine cytomegalovirus linked to the major histocompatibility complex of the mouse. J Gen Virol. 1977;37:107-114.

40. Chandler $\mathrm{SH}$, Handsfield $\mathrm{HH}, \mathrm{McD}$ ougall JK . Isolation of multiple strains of cytomegalovirus from women attending a clinic for sexually transmitted disease. $J$ Infect Dis. 1987;155:655-660.

41. Chee MS, Bankier AT, Beck S, Bohni R, Brown CM, Cerny R, Horsnell T, Hutchison CA, 3rd, Kouzarides T, Martignetti JA, et al. Analysis of the protein-coding content of the sequence of human cytomegalovirus strain AD169. Curr Top Microbiol Immunol, 1990;154:125-169.

42. Chou S, Marousek G, Guentzel S, Follansbee SE, Poscher ME, Lalezari JP, Miner RC, Drew $\mathrm{WL}$. Evolution of mutations conferring multidrug resistance during prophylaxis and therapy for cytomegalovirus disease. J Infect Dis. 1997:176:786-789.

43. Chou SW, Scott KM. Rapid quantitation of cytomegalovirus and assay of neutralizing antibody by using monoclonal antibody to the major immediate-early viral protein. $J$ Clin Microbiol. 1988:26:504-507.

44. Chretien JH, McGinniss CG, Muller A. Venereal causes of cytomegalovirus mononucleosis. JAMA. 1977:238:1644-1645. 
45. Chrisp P, Clissold SP. Foscarnet. A review of its antiviral activity, pharmacokinetic properties and therapeutic use in immunocompromised patients with cytomegalovirus retinitis. Drugs. 1991:41:104-129.

46. Collins T, Pomeroy C, Jordan MC. Detection of latent cytomegalovirus DNA in diverse organs of mice. $J$ Infect Dis. 1993;168:725-729.

47. Compton T, Nepomuceno RR, Nowlin DM. Human cytomegalovirus penetrates host cells by $\mathrm{pH}$-independent fusion at the cell surface. Virology. 1992;191:387-395.

48. Cramer DV, Qian SQ, Harnaha J, Chapman FA, Estes LW. Starzl TE, Makowka L. Cardiac transplantation in the rat. I. The effect of histocompatibility differences on graft arteriosclerosis. Transplantation. 1989:47:414-419.

49. Cull VS, Broomfield S, Bartlett EJ, Brekalo NL, James CM. Coimmunisation with type I IFN genes enhances protective immunity against cytomegalovirus and myocarditis in $\mathrm{gB}$ DNAvaccinated mice. Gene Ther. 2002;9:1369-1378.

50. Cyrus T, Sung S, Zhao L, Funk CD, Tang S, Pratico D. Effect of low-dose aspirin on vascular inflammation, plaque stability, and atherogenesis in low-density lipoprotein receptor-deficient mice. Circulation. 2002;106:1282-1287.

51. Danesh J, Collins R, Peto R. Chronic infections and coronary heart disease: is there a link? [see comments]. Lancet. 1997;350:430-436.

52. Davis-Poynter NJ, Lynch DM, Vally H, Shellam GR, Rawlinson WD, Barrell BG, Farrell HE. Identification and characterization of a $\mathrm{G}$ protein-coupled receptor homolog encoded by murine cytomegalovirus. J Virol. 1997;71:1521-1529.

53. de Graan-Hentzen YC, Gratama JW, Mudde GC, Verdonck LF, Houbiers JG, Brand A, Sebens FW, van Loon AM, The TH, Willemze R, et al. Prevention of primary cytomegalovirus infection in patients with hematologic malignancies by intensive white cell depletion of blood products. Transfusion. 1989;29:757-760.

54. Denijn M, Schuurman HJ, Jacobse KC, De Weger RA. In situ hybridization: a valuable tool in diagnostic pathology. APMIS. 1992;100:669-681.

55. Depatie C, Chalifour A, Pare C, Lee SH, Vidal SM, Lemieux S. Assessment of Cmv1 candidates by genetic mapping and in vivo antibody depletion of NK cell subsets. Int Immunol. 1999;11:1541-1551.

56. Diethelm AG, Gore I, Ch'ien LT, Sterling WA, Morgan JM. Gastrointestinal hemorrhage secondary to cytomegalovirus after renal transplantation. A case report and review of the problem. Am J Surg. 1976;131:371-374.

57. Dix RD, Cray C, Cousins SW. Antibody alone does not prevent experimental cytomegalovirus retinitis in mice with retrovirus-induced immunodeficiency (MAIDS). Ophthalmic Res. $1997 ; 29: 381-392$

58. Eich D, Thompson JA, Ko DJ, Hastillo A, Lower R, Katz S, Katz M, Hess ML. Hypercholesterolemia in long-term survivors of heart transplantation: an early marker of accelerated coronary artery disease. J Heart Lung Transplant. 1991:10:45-49.

59. Emeson EE, Shen ML, Bell CG, Qureshi A. Inhibition of atherosclerosis in CD4 T-cell-ablated and nude (nu/nu) C57BL/6 hyperlipidemic mice. Am J Pathol. 1996;149:675-685.

60. Engels W. Grauls G, Lemmens PJ, Mullers WJ, Bruggeman CA. Influence of a cytomegalovirus infection on functions and arachidonic acid metabolism of rat peritoneal macrophages. J Leukoc Biol. 1989;45:466-473.

61. Engels W. Lemmens PJ, Muller AD, Van Dam-Mieras MC. Hornstra G. The effect of viral infection on eicosanoid formation and procoagulant activity of rat peritoneal macrophages. Role of the dietary fat type. Eicosanoids. 1992;5:73-80.

62. Evans PC, Soin A, Wreghitt TG, Taylor CJ, Wight DG, Alexander GJ. An association between cytomegalovirus infection and chronic rejection after liver transplantation. Transplantation. 2000;69:30-35.

63. Fabricant CG, Fabricant J, Litrenta MM, Minick CR. Virus-induced atherosclerosis. J Exp Med, $1978 ; 148: 335-340$.

64. Fairweather D, Kaya Z, Shellam GR, Lawson CM, Rose NR. From infection to autoimmunity. $J$ Autoimmun. 2001;16:175-186.

65. Fajac A, Vidaud M, Lebargy F, Stephan F, Ricci S, Geslin P, Goossens M, Bernaudin JF. Evaluation of human cytomegalovirus latency in alveolar macrophages. Am J Respir Crit Care Med. 1994;149:495-499.

66. Farrell HE, Shellam GR. Protection against murine cytomegalovirus infection by passive transfer of neutralizing and non-neutralizing monoclonal antibodies. J Gen Virol. 1991:72:149. 156. 
67. Farrell HE, Vally H, Lynch DM, Fleming P, Shellam GR, Scalzo AA, Davis-Poynter NJ. Inhibition of natural killer cells by a cytomegalovirus MHC class I homologue in vivo. Nature. 1997:386:510-514.

68. Faulds D, Heel RC. Ganciclovir. A review of its antiviral activity, pharmacokinetic properties and therapeutic efficacy in cytomegalovirus infections. Drugs. 1990;39:597-638.

69. Gao EK, $\mathrm{Yu} X \mathrm{XH}$. Lin $\mathrm{CP}$. Zhang H. Kaplan HJ. Intraocular viral replication after systemic murine cytomegalovirus infection requires immunosuppression. Invest Ophthalmol Vis Sci. 1995:36:2322-2327.

70. Gattone M, lacoviello L, Colombo M, Castelnuovo AD, Soffiantino F, Gramoni A, Picco D, Benedetta M, Giannuzzi P. Chlamydia pneumoniae and cytomegalovirus seropositivity, inflammatory markers, and the risk of myocardial infarction at a young age. Am Heart $\mathrm{J}$. 2001:142:633-640.

71. Gehrz RC, Rutzick SR. Cytomegalovirus (CMV)-specific lysis of CMV-infected target cells can be mediated by both NK-like and virus-specific cytotoxic T lymphocytes. Clin Exp Immunol. 1985;61:80-89.

72. Geist LJ, Hinde SL, Susceptibility to cytomegalovirus infection may be dependent on the cytokine response to the virus. J Investig Med. 2001:49:434-441.

73. Gerna G, Zipeto D, Percivalle E, Parea M, Revello MG, Maccario R, Peri G, Milanesi G. Human cytomegalovirus infection of the major leukocyte subpopulations and evidence for initial viral replication in polymorphonuclear leukocytes from viremic patients. J Infect Dis. 1992:166:1236-1244.

74. Gibbons AE, Price P. Shellam GR. Analysis of hematopoietic stem and progenitor cell populations in cytomegalovirus-infected mice. Blood. 1995;86:473-481.

75. Giezeman-Smits KM, Kuppen PJ, Ensink NG, Eggermont AM, Stals F, Wonigeit K, Fleuren GJ. The role of MHC class I expression in rat NK cell-mediated lysis of syngeneic tumor cells and virus-infected cells. Immunobiology. 1996;195:286-299.

76. Grattan MT, Moreno Cabral CE, Starnes VA, Oyer PE, Stinson EB, Shumway NE. Cytomegalovirus infection is associated with cardiac allograft rejection and atherosclerosis. JAMA. 1989;261:3561-3566.

77. Grefte JM, van der Gun BT, Schmolke S, van der Giessen M, van Son WJ, Plachter B, Jahn G, The TH. The lower matrix protein pp65 is the principal viral antigen present in peripheral blood leukocytes during an active cytomegalovirus infection. J Gen Virol. 1992;73:2923-2932.

78. Gribaudo G, Ravaglia S, Caliendo A, Cavallo R, Gariglio M, Martinotti MG, Landolfo S. Interferons inhibit onset of murine cytomegalovirus immediate-early gene transcription. Virology. 1993;197:303-311.

79. Griffiths MM, Sawitzke AD. Harper DS, McCall S, Reese VR, Cannon GW. Exacerbation of collagen-induced arthritis in rats by rat cytomegalovirus is antigen-specific. Autoimmunity. 1994:18:177-187.

80. Grundy JE, Mackenzie JS, Stanley NF. Influence of $\mathrm{H}-2$ and non- $\mathrm{H}-2$ genes on resistance to murine cytomegalovirus infection. Infect Immun. 1981:32:277-286.

81. Guetta E, Guetta V. Shibutani T, Epstein SE. Monocytes harboring cytomegalovirus: interactions with endothelial cells, smooth muscle cells, and oxidized low-density lipoprotein. Possible mechanisms for activating virus delivered by monocytes to sites of vascular injury. Circ Res. 1997:81:8-16.

82. Gupta S, Camm AJ. Chronic infection in the etiology of atherosclerosis-the case for Chlamydia pneumoniae. Clin Cardiol. 1997;20:829-836.

83. Gupta S, Pablo AM, Jiang X. Wang N, Tall AR, Schindler C. IFN-gamma potentiates atherosclerosis in ApoE knock-out mice. J Clin Invest. 1997;99:2752-2761.

84. Gurevich I. Cunha BA. Non-parenteral transmission of cytomegalovirus in a neonatal intensive care unit. Lancet. 1981:2:222-224.

85. Haagmans BL, Stals FS, van der Meide PH, Bruggeman CA. Horzinek MC, Schijns VE. Tumor necrosis factor alpha promotes replication and pathogenicity of rat cytomegalovirus. $J$ Virol. $1994: 68: 2297-2304$.

86. Haagmans BL, van den Eertwegh AJ, Claassen E, Horzinek MC, Schijns VE. Tumour necrosis factor-alpha production during cytomegalovirus infection in immunosuppressed rats. $J$ Gen Virol. 1994:75 ( Pt 4):779-787.

87. Haagmans BL, van der Meide PH, Stals FS, van den Eertwegh AJ, Claassen E, Bruggeman CA, Horzinek MC, Schijns VE. Suppression of rat cytomegalovirus replication by antibodies against gamma interferon. J Virol. 1994;68:2305-2312. 
88. Hamano S, Yoshida H, Takimoto H, Sonoda K, Osada K, He X, Minamishima Y, Kimura G, Nomoto K. Role of macrophages in acute murine cytomegalovirus infection. Microbiol Immunol. 1998;42:607-616.

89. Hanson LK, Slater JS, Karabekian Z, Virgin HWt, Biron CA, Ruzek MC, van Rooijen N, Ciavarra RP, Stenberg RM, Campbell AE. Replication of murine cytomegalovirus in differentiated macrophages as a determinant of viral pathogenesis. J Virol. 1999;73:59705980.

90. Hansson GK. Immune mechanisms in atherosclerosis. Arterioscler Thromb Vasc Biol. 2001:21:1876-1890.

91. Hansson GK, Libby $P$, Schonbeck $U, Y$ an $Z$. Innate and adaptive immunity in the pathogenesis of atherosclerosis. Circ Res. 2002;91:281-291.

92. Hayashi K, Suwa Y, Shimomura Y, Ohashi Y. Pathogenesis of ocular cytomegalovirus infection in the immunocompromised host. J Med Virol. 1995;47:364-369.

93. Hayes K, Danks DM, Gibas H, Jack I. Cytomegalovirus in human milk. N Engl J Med. 1972;287:177-178.

94. Hayes K, Alford C, Britt W. Antibody response to virus-encoded proteins after cytomegalovirus mononucleosis. J Infect Dis. 1987;156:615-621.

95. He X, Yoshida H. Minamishima Y. Nomoto K. Analysis of the role of CD4+ T-cells during murine cytomegalovirus infection in different strains of mice. Virus Res. 1995;36:233-245.

96. Heieren MH, Kim YK, Balfour $\mathrm{HH}$, Jr. Human cytomegalovirus infection of kidney glomerular visceral epithelial and tubular epithelial cells in culture. Transplantation, 1988;46:426-432.

97. Heise MT, Virgin HWt. The T-cell-independent role of gamma interferon and tumor necrosis factor alpha in macrophage activation during murine cytomegalovirus and herpes simplex virus infections. J Virol. 1995;69:904-909.

98. Hendrix MG, Salimans MM, van Boven CP. Bruggeman CA. High prevalence of latently present cytomegalovirus in arterial walls of patients suffering from grade III atherosclerosis. Am J Pathol. 1990;136:23-28.

99. Hengel H, Reusch U, Gutermann A, Ziegler H, Jonjic S, Lucin P, Koszinowski UH. Cytomegaloviral control of MHC class I function in the mouse. Immunol Rev. 1999:168:167176.

100. Hillebrands JL, Klatter FA, Bruggeman CA, Rozing J. Development of transplant arteriosclerosis after allogeneic aorta transplantation in the rat: influence of recipient genotype. Transplant Proc. 2001;33:324-325.

101. Ho M, Suwansirikul S, Dowling JN, Youngblood LA, Armstrong JA. The transplanted kidney as a source of cytomegalovirus infection. N Engl J Med. 1975;293:1109-1112.

102. Holtappels R, Podlech J, Geginat G, Steffens HP. Thomas D, Reddehase MJ. Control of murine cytomegalovirus in the lungs: relative but not absolute immunodominance of the immediate-early 1 nonapeptide during the antiviral cytolytic T-lymphocyte response in pulmonary infiltrates. $J$ Virol. 1998;72:7201-7212.

103. Hosie MJ, Dunsford T, Klein D, Willett BJ, Cannon C, Osborne R, Macdonald J, Spibey N, Mackay N, Jarrett O. Neil JC. Vaccination with inactivated virus but not viral DNA reduces virus load following challenge with a heterologous and virulent isolate of feline immunodeficiency virus. J Virol. 2000;74:9403-9411.

104. Hsich E, Zhou YF, Paigen B, Johnson TM, Burnett MS, Epstein SE. Cytomegalovirus infection increases development of atherosclerosis in Apolipoprotein-E knockout mice. Atherosclerosis. 2001;156:23-28.

105. Ibanez CE, Schrier R, Ghazal P, Wiley C, Nelson JA. Human cytomegalovirus productively infects primary differentiated macrophages. J Virol. 1991;65:6581-6588.

106. Irmiere A, Gibson W. Isolation and characterization of a noninfectious virion-like particle released from cells infected with human strains of cytomegalovirus. Virology. 1983:130:118133.

107. Ishibashi S, Brown MS, Goldstein JL, Gerard RD, Hammer RE, Herz J, Hypercholesterolemia in low density lipoprotein receptor knockout mice and its reversal by adenovirus-mediated gene delivery. J Clin Invest. 1993;92:883-893.

108. Ishibashi S, Goldstein JL. Brown MS, Herz J, Burns DK. Massive xanthomatosis and atherosclerosis in cholesterol-fed low density lipoprotein receptor-negative mice. J Clin Invest. 1994:93:1885-1893.

109. Ishihara S, Fukuda R. Kawashima K, Moriyama N. Suetsugu H, Ishimura N, Kazumori H. Kaji T, Sato H, Okuyama T, Rumi KM, Adachi K, Watanabe M, Kinoshita Y. T cell-mediated cytotoxicity via Fas/Fas ligand signaling in Helicobacter pylori-infected gastric corpus. Helicobacter. 2001;6:283-293. 
110. Ishii S, Arizono H, Nagao T, Kudo S, Kondo S, Kiyoki M. Pharmacokinetics of a new human monoclonal antibody against cytomegalovirus. Second communication: distribution and elimination of the new monoclonal antibody, regavirumab after repeated administration in rats, and placental transfer and milk-passage study after single administration to pregnant and lactating rats. Arzneimittelforschung. 1994;44:899-908.

111. Iuliano L. The oxidant stress hypothesis of atherogenesis. Lipids. 2001;36 Suppl:S41-44.

112. Jahn G, Scholl BC. Traupe B, Fleckenstein B. The two major structural phosphoproteins (pp65 and pp 150) of human cytomegalovirus and their antigenic properties. J Gen Virol. 1987;68 ( Pt 5):1327-1337.

113. Jonjic S, Pavic I, Lucin P, Rukavina D, Koszinowski UH. Efficacious control of cytomegalovirus infection after long-term depletion of CD8+ T lymphocytes. J Virol. 1990;64:5457-5464.

114. Kaariainen L, Klemola E, Paloheimo J. Rise of cytomegalovirus antibodies in an infectiousmononucleosis-like syndrome after transfusion. Br Med J. 1966;5498:1270-1272.

115. Kagi D, Ledermann B, Burki K, Seiler P, Odermatt B, Olsen KJ, Podack ER, Zinkernagel RM, Hengartner $\mathrm{H}$. Cytotoxicity mediated by $\mathrm{T}$ cells and natural killer cells is greatly impaired in perforin-deficient mice. Nature. 1994;369:31-37.

116. Kalil RS, Hudson SL, Gaston RS. Determinants of cardiovascular mortality after renal transplantation: a role for cytomegalovirus? Am J Transplant. 2003;3:79-81.

117. Kaptein SJ, Beisser PS, Gruijthuijsen YK, Savelkouls KG, Van Cleef KW, Beuken E, Grauls GE, Bruggeman CA, Vink C. The rat cytomegalovirus $\mathrm{R} 78 \mathrm{G}$ protein-coupled receptor gene is required for production of infectious virus in the spleen. J Gen Virol. 2003;84:2517-2530.

118. Karre K. Clever, cleverer, cleverest. Nat Immunol. 2002;3:505-506.

119. Kavanagh DG, Hill AB. Evasion of cytotoxic T lymphocytes by murine cytomegalovirus. Semin Immunol. 2001;13:19-26.

120. Kercher L, Mitchell BM. Persisting murine cytomegalovirus can reactivate and has unique transcriptional activity in ocular tissue. J Virol. 2002;76:9165-9175.

121. Kilham L, Margolis G. Encephalitis in suckling rats induced with rat cytomegalovirus. Lab Invest. 1975;33:200-206.

122. King VL, Szilvassy SJ, Daugherty A. Interleukin-4 deficiency decreases atherosclerotic lesion formation in a site-specific manner in female LDL receptor-\%- mice. Arterioscler Thromb Vasc Biol. 2002;22:456-461.

123. Kleijnen MF, Huppa JB, Lucin P. Mukherjee S, Farrell H, Campbell AE, Koszinowski UH, Hill AB, Ploegh HL. A mouse cytomegalovirus glycoprotein, gp34, forms a complex with folded class I MHC molecules in the ER which is not retained but is transported to the cell surface. EMBO J. 1997:16:685-694.

124. Klemola E, Stenstrom R, von Essen R. Pneumonia as a clinical manifestation of cytomegalovirus infection in previously healthy adults. Scand J Infect Dis. 1972;4:7-10.

125. Kloover JS, Vanagt WY, Stals FS, Bruggeman CA. Effective treatment of experimental cytomegalovirus-induced encephalo-meningitis in immunocompromised rats with HPMPC. Antiviral Res. 1997;35:105-112.

126. Kloover JS, Grauls GE, Blok MJ, Vink C, Bruggeman CA. A rat cytomegalovirus strain with a disruption of the $\mathrm{r} 144 \mathrm{MHC}$ class I-like gene is attenuated in the acute phase of infection in neonatal rats. Arch Virol. 2002;147:813-824.

127. Knight DA, Waldman WJ, Sedmak DD. Cytomegalovirus-mediated modulation of adhesion molecule expression by human arterial and microvascular endothelial cells. Transplantation. 1999:68:1814-1818.

128. Koffron AJ, Mueller KH, Kaufman DB, Stuart FP, Patterson B, Abecassis MI. Direct evidence using in situ polymerase chain reaction that the endothelial cell and T-lymphocyte harbor latent murine cytomegalovirus. Scand J Infect Dis Suppl, 1995;99:61-62.

129. Koffron AJ, Hummel M, Patterson BK, Yan S, Kaufman DB, Fryer JP, Stuart FP, Abecassis MI. Cellular localization of latent murine cytomegalovirus. J Virol. 1998;72:95-103.

130. Komminoth P. Heitz PU, Long AA. In situ polymerase chain reaction: general methodology and recent advances. Verh Dtsch Ges Pathol. 1994;78:146-152.

131. Koppelman B, Neefjes JJ, de Vries JE, de Waal Malefyt R. Interleukin-10 down-regulates MHC class II alphabeta peptide complexes at the plasma membrane of monocytes by affecting arrival and recycling. Immunity. 1997;7:861-871.

132. Kosugi I, Shinmura Y, Kawasaki H. Arai Y, Li RY, Baba S, Tsutsui Y. Cytomegalovirus infection of the central nervous system stem cells from mouse embryo: a model for developmental brain disorders induced by cytomegalovirus. Lab Invest. 2000;80:1373-1383. 
133. Kosugi I, Kawasaki $H$, Arai $Y$, Tsutsui $Y$, Innate immune responses to cytomegalovirus infection in the developing mouse brain and their evasion by virus-infected neurons. Am $J$ Pathol. 2002;161:919-928.

134. Koszinowski UH, Del Val M, Reddehase MJ. Cellular and molecular basis of the protective immune response to cytomegalovirus infection. Curr Top Microbiol Immunol. 1990;154:189220.

135. Koszinowski UH. Molecular aspects of immune recognition of cytomegalovirus. Transplant Proc. 1991:23:70-73, discussion 74.

136. Kotenko SV, Saccani S, Izotova LS, Mirochnitchenko OV, Pestka S. Human cytomegalovirus harbors its own unique IL-10 homolog (cmvlL-10). Proc Natl Acad Sci USA. 2000;97:16951700.

137. Krmpotic A, Busch DH, Bubic I, Gebhardt F, Hengel H, Hasan M, Scalzo AA, Koszinowski UH, Jonjic S. MCMV glycoprotein gp40 confers virus resistance to CD8 $+\mathrm{T}$ cells and NK cells in vivo. Nat Immunol. 2002;3:529-535.

138. Kubota A, Kubota S, Farrell HE, Davis Poynter N, Takei F. Inhibition of NK cells by murine CMV-encoded class I MHC homologue m144. Cell Immunol. 1999;191:145-151.

139. Kurz S, Steffens HP, Mayer A, Harris JR, Reddehase MJ. Latency versus persistence or intermittent recurrences: evidence for a latent state of murine cytomegalovirus in the lungs. $J$ Virol. 1997:71:2980-2987.

140. Kurz SK, Rapp M, Steffens HP, Grzimek NK, Schmaiz S, Reddehase MJ. Focal transcriptional activity of murine cytomegalovirus during latency in the lungs. J Virol. 1999;73:482-494.

141. Lagenaur LA, Manning WC, Vieira J, Martens CL, Mocarski ES. Structure and function of the murine cytomegalovirus sgg1 gene: a determinant of viral growth in salivary gland acinar cells. $J$ Virol. 1994:68:7717-7727.

142. Landini MP, Rossier E, Schmitz $H$. Antibodies to human cytomegalovirus structural polypeptides during primary infection. J Virol Methods. 1988;22:309-317.

143. Landini MP. New approaches and perspectives in cytomegalovirus diagnosis. Prog Med Virol. 1993:40:157-177.

144. Lang DJ, Kummer JF. Demonstration of cytomegalovirus in semen. $N$ Engl $J$ Med. 1972;287:756-758.

145. Lathbury LJ, Allan JE, Shellam GR, Scalzo AA. Effect of host genotype in determining the relative roles of natural killer cells and $T$ cells in mediating protection against murine cytomegalovirus infection. J Gen Virol. 1996;77:2605-2613.

146. Lathey JL, Spector SA. Unrestricted replication of human cytomegalovirus in hydrocortisonetreated macrophages. J Virol. 1991;65:6371-6375.

147. Lawson CM, Grundy JE, Shellam GR. Antibody responses to murine cytomegalovirus in genetically resistant and susceptible strains of mice. J Gen Virol. 1988;69:1987-1998.

148. Lawson CM, O'Donoghue HL, Reed WD. Mouse cytomegalovirus infection induces antibodies which cross-react with virus and cardiac myosin: a model for the study of molecular mimicry in the pathogenesis of viral myocarditis. Immunology. 1992;75:513-519.

149. Laycock KA, Fenoglio ED, Hook KK, Pepose JS. An in vivo model of human cytomegalovirus retinal infection. Am J Ophthalmol. 1997;124:181-189.

150. Laycock KA, Kumano Y. Pepose JS. Reproduction of antiviral effect in an in vivo model of human cytomegalovirus retinal infection. Graefes Arch Clin Exp Ophthalmol. 1998;236:527530.

151. Lea AP. Bryson HM. Cidofovir. Drugs. 1996;52:225-230; discussion 231.

152. Lee M, Abenes G, Zhan X. Dunn W. Haghjoo E. Tong T, Tam A, Chan K, Liu F. Genetic analyses of gene function and pathogenesis of murine cytomegalovirus by transposonmediated mutagenesis. J Clin Virol. 2002;25 Suppl 2:S111-122.

153. Lee SH, Zafer A, de Repentigny Y, Kothary R, Tremblay ML, Gros P, Duplay P, Webb JR, Vidal SM. Transgenic expression of the activating natural killer receptor $\mathrm{Ly} 49 \mathrm{H}$ confers resistance to cytomegalovirus in genetically susceptible mice. J Exp Med. 2003:197:515-526.

154. Lemstrom K, Koskinen P. Krogerus L, Daemen M, Bruggeman C, Hayry P. Cytomegalovirus antigen expression, endothelial cell proliferation, and intimal thickening in rat cardiac allografts after cytomegalovirus infection. Circulation. 1995;92:2594-2604.

155. Lemstrom KB, Bruning JH, Bruggeman CA, Lautenschlager IT, Hayry PJ. Cytomegalovirus infection enhances smooth muscle cell proliferation and intimal thickening of rat aortic allografts. J Clin Invest. 1993:92:549-558.

156. Lenzo JC, Fairweather D. Shellam GR, Lawson CM. Immunomodulation of murine cytomegalovirus-induced myocarditis in mice treated with lipopolysaccharide and tumor necrosis factor. Cell Immunol. 2001:213:52-61. 
157. Lenzo JC, Shellam GR, Lawson CM. Ganciclovir and cidofovir treatment of cytomegalovirusinduced myocarditis in mice. Antimicrob Agents Chemother. 2001;45:1444-1449.

158. Lenzo JC, Fairweather D. Cull V. Shellam GR, James Lawson CM. Characterisation of murine cytomegalovirus myocarditis: cellular infiltration of the heart and virus persistence. $J$ Mol Cell Cardiol. 2002:34:629-640.

159. Li F, Grauls G, Yin M, Bruggeman CA. Initial endothelial injury and cytomegalovirus infection accelerate the development of allograft arteriosclerosis. Transplant Proc. 1995;27:3552-3554.

160. Liu YN, Klaus A, Kari B, Stinski MF, Eckhardt J, Gehrz RC. The N-terminal 513 amino acids of the envelope glycoprotein $\mathrm{gB}$ of human cytomegalovirus stimulates both $\mathrm{B}$ - and T-cell immune responses in humans. J Virol. 1991;65:1644-1648.

161. Ljunggren HG, Karre K. In search of the 'missing self: MHC molecules and NK cell recognition. Immunol Today, 1990;11:237-244.

162. Loree HM, Tobias BJ, Gibson LJ, Kamm RD, Small DM, Lee RT. Mechanical properties of model atherosclerotic lesion lipid pools. Arterioscler Thromb. 1994:14:230-234.

163. Luby JP, Burnett W, Hull AR, Ware AJ, Shorey JW, Peters PC. Relationship between cytomegalovirus and hepatic function abnormalities in the period after renal transplant. $J$ Infect Dis. 1974:129:511-518.

164. Lutgens E, Gorelik L, Daemen MJ, de Muinck ED, Grewal IS, Koteliansky VE, Flavell RA. Requirement for CD154 in the progression of atherosclerosis. Nat Med. 1999;5:1313-1316.

165. MacDonald MR, Li XY, Stenberg RM, Campbell AE, Virgin HWt. Mucosal and parenteral vaccination against acute and latent murine cytomegalovirus (MCMV) infection by using an attenuated MCMV mutant. J Virol. 1998;72:442-451.

166. Matsuzawa H. Shimizu K, Okada K, Ando K, Hashimoto K, Koga $Y$. Analysis of target organs for the latency of murine cytomegalovirus DNA using specific pathogen free and germfree mice. Arch Virol. 1995;140:853-864.

167. Mayo D, Armstrong JA, Ho M. Activation of latent murine cytomegalovirus infection: cocultivation, cell transfer, and the effect of immunosuppression. J Infect Dis. 1978;138:890896.

168. McGillicuddy CJ, Carrier MJ, Weinberg PD. Distribution of lipid deposits around aortic branches of mice lacking LDL receptors and apolipoprotein E. Arterioscler Thromb Vasc Biol. 2001;21:1220-1225.

169. Meier JL, Stinski MF. Regulation of human cytomegalovirus immediate-early gene expression. Intervirology. 1996;39:331-342.

170. Melnick JL, Petrie BL, Dreesman GR, Burek J, McCollum CH, DeBakey ME. Cytomegalovirus antigen within human arterial smooth muscle cells. Lancet. 1983;2:644-647.

171. Melnick JL. Adam E, Debakey ME. Cytomegalovirus and atherosclerosis. Eur Heart J. 1993;14 Suppl K:30-38.

172. Mendall MA, Goggin PM, Molineaux N, Levy J, Toosy T, Strachan D, Camm AJ, Northfield TC. Relation of Helicobacter pylori infection and coronary heart disease. Br Heart J. 1994:71:437. 439.

173. Mercer JA, Spector DH. Pathogenesis of acute murine cytomegalovirus infection in resistant and susceptible strains of mice. J Virol. 1986;57:497-504.

174. Mettenleiter TC. Herpesvirus assembly and egress. J Virol. 2002;76:1537-1547.

175. Meyer-Konig U. Serr A, von Laer D. Kirste G. Wolff C. Haller O, Neumann-Haefelin D, Hufert FT. Human cytomegalovirus immediate early and late transcripts in peripheral blood leukocytes: diagnostic value in renal transplant recipients. J Infect Dis. 1995:171:705-709.

176. Middeldorp JM, Jongsma J, ter Haar A, Schirm J, The TH. Detection of immunoglobulin M and G antibodies against cytomegalovirus early and late antigens by enzyme-linked immunosorbent assay. J Clin Microbiol. 1984:20:763-771.

177. Mocarski ES. Cytomegaloviruses and their replication. In: Fields BN, Knipe DM, Howley PM, eds. Fields Virology. Philadelphia: Lippincott-Raven Publishers: 1996: 2447-2492.

178. Mocarski ES, Jr. Immunomodulation by cytomegaloviruses: manipulative strategies beyond evasion. Trends Microbiol. 2002;10:332-339.

179. Montgomery R, Youngblood L, Medearis DN, Jr. Recovery of cytomegalovirus from the cervix in pregnancy. Pediatrics. 1972;49:524-531.

180. Mori T, Nakamura M, Shimizu K, Ikeda Y, Ando K, In vivo disturbance of hematopoiesis in mice persistently infected with murine cytomegalovirus: impairment of stromal cell function. Virology. 1999;253:145-154.

181. Muhlemann K, Miller RK, Metlay L, Menegus MA. Cytomegalovirus infection of the human placenta: an immunocytochemical study. Hum Pathol. 1992;23:1234-1237. 
182. Murray HW, Knox DL, Green WR, Susel RM. Cytomegalovirus retinitis in adults. A manifestation of disseminated viral infection. Am J Med. 1977;63:574-584.

183. Myerson D, Hackman RC, Nelson JA, Ward DC, McDougall JK. Widespread presence of histologically occult cytomegalovirus. Hum Pathol. 1984:15:430-439.

184. Nakashima Y, Plump AS, Raines EW, Breslow JL, Ross R. ApoE-deficient mice develop lesions of all phases of atherosclerosis throughout the arterial tree. Arterioscler Thromb. $1994 ; 14: 133-140$.

185. Narrod J, Kormos R, Armitage J, Hardesty R, Ladowski J, Griffith B. Acute rejection and coronary artery disease in long-term survivors of heart transplantation. $J$ Heart Transplant. 1989;8:418-420; discussion 420-411.

186. Navarro D, Lennette $E$, Tugizov S, Pereira L. Humoral immune response to functional regions of human cytomegalovirus glycoprotein B. J Med Virol. 1997;52:451-459.

187. Neyts J, Balzarini J, Naesens L, De Clercq E. Efficacy of (S)-1-(3-hydroxy-2phosphonylmethoxypropyl)cytosine and 9-(1,3-dihydroxy-2-propylmethyl)guanine for the treatment of murine cytomegalovirus infection in severe combined immunodeficiency mice. J Med Virol. 1992;37:67-71.

188. Neyts J, De Clercq E. New inhibitors of cytomegalovirus replication: in vitro evaluation, mechanism of action, and in vivo activity. Verh K Acad Geneeskd Belg. 1994;56:561-592.

189. Ng-Bautista CL, Sedmak DD. Cytomegalovirus infection is associated with absence of alveolar epithelial cell HLA class II antigen expression. J Infect Dis. 1995;171:39-44.

190. Nicoletti A, Caligiuri G. Hansson GK. Immunomodulation of atherosclerosis: myth and reality. J Intern Med. 2000;247:397-405.

191. Nieto FJ, Adam E, Sorlie P, Farzadegan H, Melnick JL, Comstock GW, Szklo M. Cohort study of cytomegalovirus infection as a risk factor for carotid intimal-medial thickening, a measure of subclinical atherosclerosis [see comments]. Circulation. 1996;94:922-927.

192. Noda S. Tanaka K, Sawamura S, Sasaki M, Matsumoto T, Mikami K, Aiba Y, Hasegawa $H$, Kawabe N, Koga $Y$. Role of nitric oxide synthase type 2 in acute infection with murine cytomegalovirus. J Immunol. 2001:166:3533-3541.

193. O'Donoghue $\mathrm{HL}$, Lawson CM, Reed WD. Autoantibodies to cardiac myosin in mouse cytomegalovirus myocarditis. Immunology. 1990;71:20-28.

194. Orange JS, Wang B, Terhorst C, Biron CA. Requirement for natural killer cell-produced interferon gamma in defense against murine cytomegalovirus infection and enhancement of this defense pathway by interleukin 12 administration. J Exp Med. 1995;182:1045-1056.

195. Osler W. Diseases of the arteries. In: Osler W, ed. Modern Medecine; its theory and practice. Philadelphia: Lea \& Febiger; 1908: 426-427.

196. Paigen B, Morrow A, Brandon C, Mitchell D. Holmes P. Variation in susceptibility to atherosclerosis among inbred strains of mice. Atherosclerosis. 1985;57:65-73.

197. Paigen B, Morrow A, Holmes PA, Mitchell D, Williams RA. Quantitative assessment of atherosclerotic lesions in mice. Atherosclerosis. 1987:68:231-240.

198. Paigen B, Ishida BY, Verstuyft J, Winters RB, Albee D. Atherosclerosis susceptibility differences among progenitors of recombinant inbred strains of mice. Arteriosclerosis. 1990:10:316-323.

199. Palinski W, Rosenfeld ME, Yla-Herttuala S, Gurtner GC, Socher SS, Butler SW, Parthasarathy S, Carew TE, Steinberg D, Witztum JL. Low density lipoprotein undergoes oxidative modification in vivo. Proc Natl Acad Sci USA. 1989;86:1372-1376.

200. Palinski W, Ord VA, Plump AS, Breslow JL, Steinberg D, Witztum JL. ApoE-deficient mice are a model of lipoprotein oxidation in atherogenesis. Demonstration of oxidation-specific epitopes in lesions and high titers of autoantibodies to malondialdehyde-lysine in serum. Arterioscler Thromb. 1994;14:605-616.

201. Palmon A, Blagerman S, Tel Or S, Pecht M, Trainin N, Burstein Y, Rager Zisman B. Treatment of murine cytomegalovirus salivary-gland infection by combined therapy with ganciclovir and thymic humoral factor gamma 2. Antiviral Res. 1996;33:55-64.

202. Panjwani DD, Ball MG, Berry NJ, Wimperis JZ, Blacklock HA, Prentice HG, Hoffbrand AV, Griffiths PD. Virological and serological diagnosis of cytomegalovirus infection in bone marrow allograft recipients. J Med Virol. 1985:16:357-365.

203. Pass RF, August AM, Dworsky M, Reynolds DW. Cytomegalovirus infection in day-care center. N Engl J Med. 1982;307:477-479.

204. Patel R, Smith TF, Espy M, Wiesner RH, Krom RA, Portela D. Paya CV. Detection of cytomegalovirus DNA in sera of liver transplant recipients. J Clin Microbiol. 1994;32:1431. 1434. 
205. Pentikainen MO, Oorni K, Ala Korpela M, Kovanen PT, Modified LDL-trigger of atherosclerosis and inflammation in the arterial intima. $J$ Intern Med. 2000;247:359-370.

206. Petrie BL, Melnick JL, Adam E, Burek J, McCollum CH, DeBakey ME. Nucleic acid sequences of cytomegalovirus in cells cultured from human arterial tissue. J Infect Dis. 1987:155:158-159.

207. Plump AS, Smith JD, Hayek T, Aalto Setala K, Walsh A, Verstuyft JG, Rubin EM, Breslow JL. Severe hypercholesterolemia and atherosclerosis in apolipoprotein E-deficient mice created by homologous recombination in ES cells. Cell. 1992;71:343-353.

208. Podlech J, Holtappels R, Pahl-Seibert MF, Steffens HP, Reddehase MJ. Murine model of interstitial cytomegalovirus pneumonia in syngeneic bone marrow transplantation: persistence of protective pulmonary CD8-T-cell infiltrates after clearance of acute infection. $J$ Virol. 2000;74:7496-7507.

209. Polic B, Jonjic S, Pavic I, Crnkovic I, Zorica I, Hengel H, Lucin P, Koszinowski UH. Lack of MHC class I complex expression has no effect on spread and control of cytomegalovirus infection in vivo. J Gen Virol. 1996;77:217-225.

210. Pomeroy C, Hilleren PJ, Jordan MC. Latent murine cytomegalovirus DNA in splenic stromal cells of mice. J Virol. 1991:65:3330-3334.

211. Pomeroy C, Delong D, Clabots C, Riciputi P. Filice GA. Role of interferon-gamma in murine cytomegalovirus infection. J Lab Clin Med. 1998;132:124-133.

212. Presti RM, Pollock JL, DalCanto AJ, AK OG, Virgin HW. Interferon gamma regulates acute and latent murine cytomegalovirus infection and chronic disease of the great vessels. $J$ Exp Med. 1998:188:577-588.

213. Price $P$, Baxter AG, Allcock RN, Papadimitriou JM. Factors influencing the effects of murine cytomegalovirus on the pancreas. Eur J Clin Invest. 1998;28:546-553.

214. Prince AM, Szmuness W. Millian SJ, David DS. A serologic study of cytomegalovirus infections associated with blood transfusions. N Engl J Med. 1971;284:1125-1131.

215. Pringle CR. The universal system of virus taxonomy of the International Committee on Virus Taxonomy (ICTV), including new proposals ratified since publication of the Sixth ICTV Report in 1995. Arch Virol. 1998:143:203-210.

216. Priya K, Madhavan HN. Diagnostic value of enzyme linked immuno-sorbent assay for cytomegalovirus disease. J Postgrad Med. 2002;48:176-178; discussion 190.

217. Pulliam L, Berens ME, Rosenblum ML. A normal human brain cell aggregate model for neurobiological studies. J Neurosci Res. 1988;21:521-530.

218. Raines EW. Ross R. Smooth muscle cells and the pathogenesis of the lesions of atherosclerosis. Br Heart J. 1993:69:S30-37.

219. Rasmussen LE, Nelson RM, Kelsall DC, Merigan TC. Murine monoclonal antibody to a single protein neutralizes the infectivity of human cytomegalovirus. Proc Natl Acad Sci USA. 1984:81:876-880.

220. Reddehase MJ. Mutter W. Munch K, Buhring HJ, Koszinowski UH. CD8-positive T lymphocytes specific for murine cytomegalovirus immediate-early antigens mediate protective immunity. J Virol. 1987;61:3102-3108.

221. Reddehase MJ, Balthesen M, Rapp M, Jonjic S, Pavic I, Koszinowski UH. The conditions of primary infection define the load of latent viral genome in organs and the risk of recurrent cytomegalovirus disease. J Exp Med. 1994:179:185-193.

222. Reddehase MJ. The immunogenicity of human and murine cytomegaloviruses. Curr Opin Immunol. 2000:12:390-396.

223. Reddick RL, Zhang SH, Maeda N. Atherosclerosis in mice lacking apo E. Evaluation of lesional development and progression [published erratum appears in Arterioscler Thromb 1994 May:14(5):839]. Arterioscler Thromb. 1994:14:141-147.

224. Redpath S, Angulo A, Gascoigne NR. Ghazal P. Murine cytomegalovirus infection downregulates MHC class II expression on macrophages by induction of IL-10. J Immunol. 1999:162:6701-6707.

225. Rice PS, Kudesia G, Price C, Smith GH. Diagnosis of cytomegalovirus infection in heart transplant recipients. J Clin Pathol. 1992;45:636-637.

226. Ridker PM, Cushman M, Stampfer MJ. Tracy RP. Hennekens CH. Inflammation, aspirin, and the risk of cardiovascular disease in apparently healthy men. N Engl J Med, 1997:336:973-979.

227. Riera L, Gariglio M, Valente G, Mullbacher A, Museteanu C, Landolfo S, Simon MM. Murine cytomegalovirus replication in salivary glands is controlled by both perforin and granzymes during acute infection. Eur J Immunol. 2000:30:1350-1355.

228. Roberts WH, Sneddon JM, Waldman J, Stephens RE. Cytomegalovirus infection of gastrointestinal endothelium demonstrated by simultaneous nucleic acid hybridization and immunohistochemistry. Arch Pathol Lab Med. 1989:113:461-464. 
229. Roizman B. Herpesviridae. In: Fields BN, Knipe DM, Howley PM, eds. Fields Virology. Philadelphia: Lippincott-Raven Publishers; 1990: 2221-2230.

230. Ross $R$. The pathogenesis of atherosclerosis: a perspective for the 1990s. Nature. $1993 ; 362: 801-809$.

231. Ross R. Atherosclerosis-an inflammatory disease, N Engl J Med. 1999;340:115-126.

232. Rott D, Zhu J, Burnett MS, Zhou YF, Zalles-Ganley A, Ogunmakinwa J, Epstein SE. Effects of MF-tricyclic, a selective cyclooxygenase-2 inhibitor, on atherosclerosis progression and susceptibility to cytomegalovirus replication in apolipoprotein-E knockout mice. J Am Coll Cardiol. 2003;41:1812-1819.

233. Rummelt V, Rummelt C, Jahn G, Wenkel H, Sinzger C, Mayer UM, Naumann GO. Triple retinal infection with human immunodeficiency virus type 1 , cytomegalovirus, and herpes simplex virus type 1. Light and electron microscopy, immunohistochemistry, and in situ hybridization. Ophthalmology. 1994;101:270-279.

234. Sano N. Izumi K. Hepatic cytomegalovirus involvement in autopsy cases. Acta Pathol Jpn. 1991;41:668-672.

235. Scalzo AA, Fitzgerald NA, Simmons A, La Vista AB, Shellam GR. Cmv-1, a genetic locus that controls murine cytomegalovirus replication in the spleen. J Exp Med. 1990;171:1469-1483.

236. Scalzo AA, Fitzgerald NA, Wallace CR, Gibbons AE, Smart YC, Burton RC, Shellam GR. The effect of the Cmv-1 resistance gene, which is linked to the natural killer cell gene complex, is mediated by natural killer cells. J Immunol. 1992;149:581-589.

237. Scalzo AA, Lyons PA, Fitzgerald NA, Forbes CA, Yokoyama WM, Shellam GR. Genetic mapping of Cmv1 in the region of mouse chromosome 6 encoding the NK gene complexassociated loci Ly49 and musNKR-P1. Genomics. 1995;27:435-441.

238. Schafer P. Laufs R. Experience with quantitative PCR for the management of HCMV disease. Intervirology. 1996;39:204-212.

239. Schmader K, Henry SC, Rahija RJ, Yu Y, Daley GG, Hamilton JD. Mouse cytomegalovirus reactivation in severe combined immune deficient mice after implantation of latently infected salivary gland. J Infect Dis. 1995;172:531-534.

240. Schuster V, Matz B, Wiegand H. Traub B, Kampa D, Neumann-Haefelin D. Detection of human cytomegalovirus in urine by DNA-DNA and RNA-DNA hybridization. $J$ Infect Dis. 1986;154:309-314.

241. Schwartz RS, Henry TD. Pathophysiology of coronary artery restenosis. Rev Cardiovasc Med. 2002:3 Suppl 5:S4-9.

242. Schwartz SM, Murry CE. Proliferation and the monoclonal origins of atherosclerotic lesions. Annu Rev Med. 1998:49:437-460.

243. Schwenke DC, Carew TE. Initiation of atherosclerotic lesions in cholesterol-fed rabbits. II. Selective retention of LDL vs. selective increases in LDL permeability in susceptible sites of arteries. Arteriosclerosis. 1989;9:908-918.

244. Shah PK, Falk E, Badimon JJ, Fernandez-Ortiz A, Mailhac A, Villareal-Levy G, Fallon JT, Regnstrom J, Fuster V. Human monocyte-derived macrophages induce collagen breakdown in fibrous caps of atheroscierotic plaques. Potential role of matrix-degrading metalloproteinases and implications for plaque rupture. Circulation. 1995;92:1565-1569.

245. Shanley JD, Billingsley AM, Shelby J, Corry RJ. Transfer of murine cytomegalovirus infection by heart transplantation. Transplantation. 1983:36:584-586.

246. Shanley JD. Thrall RS, Forman SJ. Murine cytomegalovirus replication in the lungs of athymic BALB/c nude mice. J Infect Dis. 1997:175:309-315.

247. Shanley JD, Shanley JA, Albert G, Biegel D. Characterization of virus-induced interferongamma responses in mice previously infected with murine cytomegalovirus. $J$ Infect Dis. 2001;183:697-706.

248. Sharples LD, Caine N, Mullins P, Scott JP, Solis E, English TA, Large SR, Schofield PM, Wallwork J. Risk factor analysis for the major hazards following heart transplantation-rejection. infection, and coronary occlusive disease. Transplantation. 1991;52:244-252.

249. Shelby J, Saffle JR, Kern ER. Transmission of cytomegalovirus infection in mice by skin graft. J Trauma, 1988;28:203-206.

250. Simpson JA, Chow JC, Baker J, Avdalovic N, Yuan S, Au D, Co MS, Vasquez M, Britt WJ, Coelingh $\mathrm{KL}$. Neutralizing monoclonal antibodies that distinguish three antigenic sites on human cytomegalovirus glycoprotein $\mathrm{H}$ have conformationally distinct binding sites. $J$ Virol. 1993;67:489-496.

251. Sinzger C, Muntefering H, Loning T, Stoss H, Plachter B, Jahn G. Cell types infected in human cytomegalovirus placentitis identified by immunohistochemical double staining. Virchows Arch A Pathol Anat Histopathol. 1993;423:249-256. 
252. Sinzger C, Plachter B, Stenglein S, Jahn G. Immunohistochemical detection of viral antigens in smooth muscle, stromal, and epithelial cells from acute human cytomegalovirus gastritis. $J$ Infect Dis. 1993;167:1427-1432.

253. Sinzger C, Grefte A, Plachter B, Gouw AS, The TH, Jahn G. Fibroblasts, epithelial cells, endothelial cells and smooth muscle cells are major targets of human cytomegalovirus infection in lung and gastrointestinal tissues. J Gen Virol. 1995;76:741-750.

254. Sjoland H, Eitzman DT, Gordon D, Westrick R, Nabel EG, Ginsburg D. Atherosclerosis progression in LDL receptor-deficient and apolipoprotein E-deficient mice is independent of genetic alterations in plasminogen activator inhibitor-1. Arterioscler Thromb Vasc Biol. 2000;20:846-852.

255. Smee DF, Barnett BB, Sidwell RW, Reist EJ, Holy A. Antiviral activities of nucleosides and nucleotides against wild-type and drug-resistant strains of murine cytomegalovirus. Antiviral Res. 1995:26:1-9.

256. Smith PD, Saini SS, Raffeld M, Manischewitz JF, Wahl SM. Cytomegalovirus induction of tumor necrosis factor-alpha by human monocytes and mucosal macrophages. $J$ Clin Invest. 1992;90:1642-1648.

257. Smyth RL, Sinclair J, Scott JP, Gray JJ, Higenbottam TW, Wreghitt TG, Wallwork J, Borysiewicz LK. Infection and reactivation with cytomegalovirus strains in lung transplant recipients. Transplantation. 1991;52:480-482.

258. Soderberg-Naucler C, Fish KN, Nelson JA. Reactivation of latent human cytomegalovirus by allogeneic stimulation of blood cells from healthy donors. Cell. 1997:91:119-126.

259. Span AH, Grauls G, Bosman F, van Boven CP, Bruggeman CA. Cytomegalovirus infection induces vascular injury in the rat. Atherosclerosis. 1992;93:41-52.

260. Span AH, Frederik PM, Grauls G, Van Boven GP, Bruggeman CA. CMV induced vascular injury: an electron-microscopic study in the rat. In Vivo. 1993;7:567-573.

261. Speir E, Modali R, Huang ES, Leon MB, Shawl F, Finkel T, Epstein SE. Potential role of human cytomegalovirus and p53 interaction in coronary restenosis [see comments]. Science. 1994:265:391-394.

262. Spring PM, Hoff HF. LDL accumulation in the grossly normal human iliac bifurcation and common iliac arteries. Exp Mol Pathol. 1989;51:179-185.

263. Stagno S, Reynolds D, Tsiantos A, Fuccillo DA, Smith R, Tiller M, Alford CA, Jr. Cervical cytomegalovirus excretion in pregnant and nonpregnant women: suppression in early gestation. J Infect Dis. 1975;131:522-527.

264. Stagno S, Reynolds DW, Pass RF, Alford CA. Breast milk and the risk of cytomegalovirus infection. N Engl J Med. 1980;302:1073-1076.

265. Stals FS, Bosman F, van Boven CP, Bruggeman CA. An animal model for therapeutic intervention studies of $\mathrm{CMV}$ infection in the immunocompromised host. Arch Virol. 1990;114:91-107.

266. Stals FS, Zeytinoglu A, Havenith $M$, de Clercq E, Bruggeman CA. Rat cytomegalovirusinduced pneumonitis after allogeneic bone marrow transplantation: effective treatment with (S)1-(3-hydroxy-2-phosphonyl-methoxypropyl)cytosine. Antimicrob Agents Chemother. 1993:37:218-223.

267. Stals FS, Wagenaar SS, Bruggeman CA. Generalized cytomegalovirus (CMV) infection and CMV-induced pneumonitis in the rat: combined effect of 9-(1,3-dihydroxy-2propoxymethyl)guanine and specific antibody treatment. Antiviral Res. 1994;25:147-160.

268. Stals FS, Wagenaar SS, Kloover JS, Vanagt WY, Bruggeman CA. Combinations of ganciclovir and antibody for experimental CMV infections. Antiviral Res. 1996;29:61-64.

269. Stary HC, Chandler AB, Glagov S, Guyton JR, Insull W, Jr., Rosenfeld ME, Schaffer SA, Schwartz CJ, Wagner WD, Wissler RW. A definition of initial, fatty streak, and intermediate lesions of atherosclerosis. A report from the Committee on Vascular Lesions of the Council on Arteriosclerosis, American Heart Association. Arterioscler Thromb. 1994;14:840-856.

270. Stary HC, Chandler AB, Dinsmore RE, Fuster V, Glagov S, Insull W, Jr., Rosenfeld ME, Schwartz CJ, Wagner WD, Wissler RW. A definition of advanced types of atherosclerotic lesions and a histological classification of atherosclerosis. A report from the Committee on Vascular Lesions of the Council on Arteriosclerosis, American Heart Association. Circulation. 1995:92:1355-1374.

271. Steffens HP, Kurz S, Holtappels R, Reddehase MJ. Preemptive CD8 T-cell immunotherapy of acute cytomegalovirus infection prevents lethal disease, limits the burden of latent viral genomes, and reduces the risk of virus recurrence. J Virol. 1998;72:1797-1804.

272. Steinberg D, Witztum JL. Lipoproteins and atherogenesis. Current concepts. JAMA. 1990;264:3047-3052. 
273. Steinhoff G, You XM, Steinmuller C, Boeke K, Stals FS, Bruggeman CA, Haverich A. Induction of endothelial adhesion molecules by rat cytomegalovirus in allogeneic lung transplantation in the rat. Scand J Infect Dis Suppl. 1995;99:58-60.

274. Steinmuller C, Steinhoff G, Bauer D, You XM, Denzin H, Franke-Ullmann G, Hausen B, Bruggemann C, Wagner TO, Lohmann-Matthes ML, Emmendorffer A. Analysis of leukocyte activation during acute rejection of pulmonary allografts in noninfected and cytomegalovirusinfected rats. J Leukoc Biol. 1997;61:40-49.

275. Stemme S, Faber B, Holm J, Wiklund O, Witztum JL, Hansson GK. T lymphocytes from human atherosclerotic plaques recognize oxidized low density lipoprotein. Proc Natl Acad Sci USA. 1995;92:3893-3897.

276. Stinski MF. Molecular biology of cytomegaloviruses. In: Roizman B, ed. Herpesviruses. New York: Plenum; 1983: 67-113.

277. Stoddart CA, Cardin RD, Boname JM, Manning WC, Abenes GB, Mocarski ES. Peripheral blood mononuclear phagocytes mediate dissemination of murine cytomegalovirus. $J$ Virol. 1994;68:6243-6253.

278. Tanaka K, Zou JP, Takeda K, Ferrans VJ, Sandford GR, Johnson TM, Finkel T, Epstein SE. Effects of human cytomegalovirus immediate-early proteins on p53-mediated apoptosis in coronary artery smooth muscle cells. Circulation. 1999;99:1656-1659.

279. Tanaka K, Noda S. Role of nitric oxide in murine cytomegalovirus (MCMV) infection. Histol Histopathol. 2001:16:937-944.

280. Tay $\mathrm{CH}$, Welsh RM. Distinct organ-dependent mechanisms for the control of murine cytomegalovirus infection by natural killer cells. J Virol. 1997;71:267-275.

281. Taylor GA, Collazo CM, Yap GS, Nguyen K, Gregorio TA, Taylor LS, Eagleson B, Secrest L, Southon EA, Reid SW, Tessarollo L, Bray M, McVicar DW, Komschlies KL, Young HA, Biron CA, Sher A, Vande Woude GF. Pathogen-specific loss of host resistance in mice lacking the IFN-gamma- inducible gene IGTP. Proc Natl Acad Sci USA. 2000;97:751-755.

282. Taylor Wiedeman J, Sissons JG, Borysiewicz LK, Sinclair JH. Monocytes are a major site of persistence of human cytomegalovirus in peripheral blood mononuclear cells. J Gen Virol. 1991; 72:2059-2064.

283. Taylor Wiedeman J, Hayhurst GP, Sissons JG, Sinclair JH. Polymorphonuclear cells are not sites of persistence of human cytomegalovirus in healthy individuals. J Gen Virol. 1993;74:265268.

284. Taylor-Wiedeman J, Sissons P, Sinclair J. Induction of endogenous human cytomegalovirus gene expression after differentiation of monocytes from healthy carriers. $J$ Virol. 1994;68:15971604.

285. Temperton NJ. DNA vaccines against cytomegalovirus: current progress. Int J Antimicrob Agents. 2002;19:169-172.

286. Thale R, Lucin P, Schneider K, Eggers M, Koszinowski UH. Identification and expression of a murine cytomegalovirus early gene coding for an Fc receptor. J Virol. 1994;68:7757-7765.

287. Tolpin MD, Stewart JA, Warren D, Mojica BA, Collins MA, Doveikis SA, Cabradilla C, Jr., Schauf V, Raju TN, Nelson K. Transfusion transmission of cytomegalovirus confirmed by restriction endonuclease analysis. J Pediatr. 1985;107:953-956.

288. Toorkey CB, Carrigan DR. Immunohistochemical detection of an immediate early antigen of human cytomegalovirus in normal tissues. $J$ Infect Dis. 1989;160:741-751.

289. Trgovcich J, Stimac D, Polic B, Krmpotic A, Pernjak-Pugel E, Tomac J, Hasan M, Wraber B, Jonjic S. Immune responses and cytokine induction in the development of severe hepatitis during acute infections with murine cytomegalovirus. Arch Virol. 2000;145:2601-2618.

290. Tricot O, Mallat Z, Heymes C, Belmin J, Leseche G, Tedgui A. Relation between endothelial cell apoptosis and blood flow direction in human atherosclerotic plaques. Circulation. 2000:101:2450-2453.

291. Tsutsui $Y$. Developmental disorders of the mouse brain induced by murine cytomegalovirus: animal models for congenital cytomegalovirus infection. Pathol Int. 1995:45:91-102.

292. Tumilowicz JJ. Characteristics of human arterial smooth muscle cell cultures infected with cytomegalovirus. In Vitro Cell Dev Biol. 1990;26:1144-1150.

293. Urban M, Klein M, Britt WJ, Hassfurther E, Mach M. Glycoprotein H of human cytomegalovirus is a major antigen for the neutralizing humoral immune response. J Gen Virol. 1996;77 ( Pt 7):1537-1547.

294. van Dam JG, Damoiseaux JG, Van der Heijden HA, Grauls G, Van Breda Vriesman PJ, Bruggeman CA. Infection with rat cytomegalovirus (CMV) in the immunocompromised host is associated with the appearance of a T cell population with reduced CD8 and T cell receptor (TCR) expression. Clin Exp Immunol. 1997;110:349-357. 
295. Visser MR, Vercellotti GM. Herpes simplex virus and atherosclerosis. Eur Heart J. 1993:14 Suppl K:39-42.

296. Waldman WJ, Roberts WH, Davis DH, Williams MV, Sedmak DD, Stephens RE. Preservation of natural endothelial cytopathogenicity of cytomegalovirus by propagation in endothelial cells. Arch Virol, 1991:117:143-164.

297. Weber O, Bender W, Eckenberg P. Goldmann S, Haerter M, Hallenberger S, Henninger K, Reefschlager J, Trappe J, Witt-Laido A, Ruebsamen-Waigmann $\mathrm{H}$. Inhibition of murine cytomegalovirus and human cytomegalovirus by a novel non-nucleosidic compound in vivo. Antiviral Res. 2001;49:179-189.

298. Weller TH, Macaulay JC, Craig JM, Wirth P. Isolation of intranuclear inclusion producing agents from infants with ilness resembling cytomegalic inclusion disease. Proc Soc Exp Biol Med. 1957:94:4-12.

299. Wentworth BB, French L. Plaque assay of cytomegalovirus strains of human origin. Proc Soc Exp Biol Med. 1970;135:253-258.

300. Wick G, Perschinka H, Xu Q. Autoimmunity and atherosclerosis. Am Heart J. 1999;138:S444449.

301. Wick G, Perschinka H. Millonig G. Atherosclerosis as an autoimmune disease: an update. Trends Immunol. 2001;22:665-669.

302. Wiertz EJ, Mukherjee S, Ploegh HL. Viruses use stealth technology to escape from the host immune system. Mol Med Today. 1997:3:116-123.

303. Wiley CA, Nelson JA. Role of human immunodeficiency virus and cytomegalovirus in AIDS encephalitis. Am J Pathol. 1988;133:73-81.

304. Williams KJ, Tabas I. The response-to-retention hypothesis of early atherogenesis. Arterioscler Thromb Vasc Biol. 1995:15:551-561.

305. Winters GL, Kendall TJ, Radio SJ, Wilson JE, Costanzo-Nordin MR, Switzer BL, Remmenga JA, McManus BM. Posttransplant obesity and hyperlipidemia: major predictors of severity of coronary arteriopathy in failed human heart allografts. J Heart Transplant. 1990:9:364-371.

306. Witting PK, Pettersson K, Ostlund-Lindqvist AM, Westerlund C, Eriksson AW, Stocker R. Inhibition by a coantioxidant of aortic lipoprotein lipid peroxidation and atherosclerosis in apolipoprotein $\mathrm{E}$ and low density lipoprotein receptor gene double knockout mice. FASEB J. 1999:13:667-675.

307. Wood D, De Backer G, Faergeman O, Graham I, Mancia G. Pyorala K. Prevention of coronary heart disease in clinical practice: recommendations of the Second Joint Task Force of European and other Societies on Coronary Prevention. Atherosclerosis. 1998;140:199-270.

308. Woodroffe SB. Garnett HM, Danis VA. Interleukin-1 production and cell-activation response to cytomegalovirus infection of vascular endothelial cells. Arch Virol. 1993:133:295-308.

309. Yagyu K, Steinhoff G, Duijvestijn AM, Bruggeman CA, Matsumoto $H$, van Breda Vriesman PJ. Reactivation of rat cytomegalovirus in lung allografts: an experimental and immunohistochemical study in rats. J Heart Lung Transplant. 1992;11:1031-1040.

310. Yagyu K, van Breda Vriesman PJ, Duijvestijn AM, Bruggeman CA, Steinhoff G. Reactivation of cytomegalovirus with acute rejection and cytomegalovirus infection with obliterative bronchiolitis in rat lung allografts. Transplant Proc. 1993:25:1152-1154.

311. Yeager AS, Grumet FC, Hafleigh EB. Arvin AM, Bradley JS, Prober CG. Prevention of transfusion-acquired cytomegalovirus infections in newborn infants. J Pediatr. 1981;98:281 287.

312. Yerkovich ST, Olver SD, Lenzo JC, Peacock CD, Price $P$. The roles of tumour necrosis factoralpha, interleukin-1 and interleukin-12 in murine cytomegalovirus infection. Immunology. 1997:91:45-52.

313. Yla Herttuala S, Palinski W, Butler SW, Picard S, Steinberg D, Witztum JL. Rabbit and human atherosclerotic lesions contain IgG that recognizes epitopes of oxidized LDL. Arterioscler Thromb. 1994:14:32-40.

314. Yonemitsu Y, Kaneda Y, Komori K, Hirai K, Sugimachi K, Sueishi K. The immediate early gene of human cytomegalovirus stimulates vascular smooth muscle cell proliferation in vitro and in vivo. Biochem Biophys Res Commun. 1997;231:447-451.

315. Yu Y, Henry SC, Xu F. Hamilton JD. Expression of a murine cytomegalovirus early-late protein in "latently" infected mice. J Infect Dis. 1995;172:371-379.

316. Zhang SH, Reddick RL, Piedrahita JA, Maeda N. Spontaneous hypercholesterolemia and arterial lesions in mice lacking apolipoprotein E. Science. 1992;258:468-471.

317. Zhou YF, Guetta E, Yu ZX, Finkel T, Epstein SE. Human cytomegalovirus increases modified low density lipoprotein uptake and scavenger receptor mRNA expression in vascular smooth muscle cells. J Clin Invest. 1996;98:2129-2138. 
318. Zhou YF, Leon MB, Waclawiw MA, Popma JJ, Yu ZX, Finkel T, Epstein SE. Association between prior cytomegalovirus infection and the risk of restenosis after coronary atherectomy. N Engl J Med. 1996;335:624-630.

319. Zhou YF, Shou M, Guetta E, Guzman R, Unger EF, Yu ZX, Zhang J, Finkel T, Epstein SE. Cytomegalovirus infection of rats increases the neointimal response to vascular injury without consistent evidence of direct infection of the vascular wall. Circulation. 1999;100:1569-1575.

320. Zhou YF, Yu ZX, Wanishsawad C, Shou M, Epstein SE. The immediate early gene products of human cytomegalovirus increase vascular smooth muscle cell migration, proliferation, and expression of PDGF beta-receptor. Biochem Biophys Res Commun. 1999;256:608-613.

321. Zhu J, Quyyumi AA, Norman JE, Costello R, Csako G, Epstein SE. The possible role of hepatitis A virus in the pathogenesis of atherosclerosis. J Infect Dis. 2000;182:1583-1587.

322. Zhu J, Nieto FJ, Horne BD, Anderson JL, Muhlestein JB, Epstein SE. Prospective study of pathogen burden and risk of myocardial infarction or death. Circulation. 2001;103:45-51.

323. Zhu JH, Quyyumi AA, Norman JE, Csako G, Waclawiw MA, Shearer GM, Epstein SE. Effects of total pathogen burden on coronary artery disease risk and C-reactive protein levels. Am J Cardiol. 2000;85:140-146.

324. Ziegler H, Thale R, Lucin P, Muranyi W, Flohr T, Hengel H, Farrell H, Rawlinson W, Koszinowski UH. A mouse cytomegalovirus glycoprotein retains $\mathrm{MHC}$ class I complexes in the ERGIC/cis-Golgi compartments. Immunity. 1997;6:57-66.

325. Zubilewicz T, Wronski J, Bourriez A, Terlecki P, Guinault AM, Muscatelli-Groux B, Michalak J, Melliere D, Becquemin JP. Allaire E. Injury in vascular surgery--the intimal hyperplastic response. Med Sci Monit. 2001;7:316-324. 



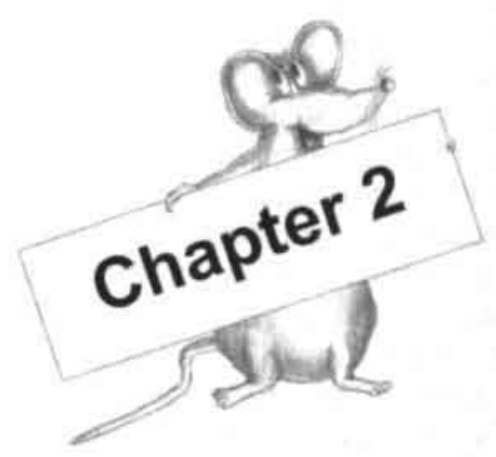

$M C M V$ infection increases early T-fymphocyte influx in atherosclerotic lesions in apoE knockout mice

INGE VLIEGEN, FRANK STASSEN, GERT GRAULS, RIEN BLOK, CATHRIEN BRUGGEMAN

Department of Medical Microbiology, Cardiovascular Research Institute Maastricht (CARIM), University of Maastricht, the Netherlands

J Clin Virol 2002 Aug;25 Suppl 2:S159-171 


\section{ABSTRACT}

Multiple epidemiological studies have suggested that cytomegalovirus (CMV) infection is associated with atherosclerotic disease. However, conclusive proof that the virus is directly related to the progression of the disease is still lacking. The goal of this study was to investigate whether MCMV is able to exacerbate the atherosclerotic process in atherosclerosis-susceptible mice. For this, apoE knockout mice kept on a chow diet were sacrificed at both 2 and 20 weeks post infection (p.i.). C57BL/6J mice fed an atherogenic diet were sacrificed at 2 weeks p.i. Lesion area, lesion composition (endothelial cells and smooth muscle cells) and inflammatory influx (T lymphocytes and macrophages) in lesions were determined. The former one was determined by means of a microscope coupled to a computer-assisted morphometry system. The latter ones were scored after immunohistochemical staining. In the chronic phase of the infection mean lesion size was significantly increased after MCMV infection in the apoE knockout mice. This increase could to a large extent be attributed to a significant increase in type $\mathrm{V}$ lesion area after MCMV infection. Also, a significant increase in T lymphocyte influx was observed in the acute phase of the infection in lesions from apoE knockout mice after MCMV infection while this effect was absent in C57BL/6J mice. After MCMV infection no increase was observed in macrophage, smooth muscle cell and endothelial cell number in lesions from both mice strains. These data suggest that MCMV infection may exacerbate the atherosclerotic process in apoE knockout mice by means of an acute lymphocytic inflammatory response. In contrast to the MCMV-induced effect in apoE knockout mice, MCMV infection did not increase the influx of T lymphocytes in atherosclerotic lesions of C57BL/6J mice. 


\section{INTRODUCTION}

Human cytomegalovirus (HCMV) infection is a major cause of morbidity and mortality in immuno-compromised individuals. Several reports have provided strong evidence that, in addition to causing acute diseases in immunocompromised patients ${ }^{5,28,35}, \mathrm{HCMV}$ may be involved in chronic diseases like atherosclerosis ${ }^{1,30,51}$. However, the underlying mechanisms for the role of $\mathrm{HCMV}$ in this disease are still lacking.

Atherosclerotic lesion formation starts with the influx of monocytes/ macrophages from the circulation, which then become loaded with lipids to create the so-called "fatty streak". These lesions may progress by the influx of additional monocytes and T lymphocytes. The products of these cells along with those of the endothelial cells can cause smooth muscle cell proliferation and migration from the media to the intima and synthesis of matrix components. When cells from the media die they create a necrotic and lipid core (extracellular cholesterol clefts). Often, the luminal face of these advanced lesions has a fibrous cap, consisting of smooth muscle cells, which stabilizes the plaque. Clinical events start as a result of intraplaque hemorrhage or rupture of the plaque surface which generates a thrombogenic surface $37,41.43$.

The development of atherosclerosis-susceptible animal models made it possible to study the atherosclerotic process in more detail ${ }^{20}, 23$. The most widely used animal models for this process are the C57BL/6J mice and the apoE knockout mice on a C57BL/6J background. C57BL/6J mice only develop atherosclerosis when fed a high cholesterol/fat diet while apoE knockout mice have no need for an atherogenic diet to develop atherosclerotic lesions. Lesion formation starts in the aortic sinus of C57BL/6J mice after 10-14 weeks on a cholesterol diet ${ }^{39}$ while adhesion of mononuclear cells to the media and subendothelial accumulation of foam cells are already observed in the aortic sinus of 8-week-old apoE knockout mice ${ }^{34}$.

The first indication that viruses potentially could cause or contribute to the development of atherosclerosis was presented by Minick and co-workers more than 25 year ago ${ }^{32}$. Since then both experimental as well as epidemiological evidence has been presented confirming a role for herpesviruses in the disease process ${ }^{2}, 18,29,38$. And although various mechanisms have been proposed to explain this effect, none of these seem to be sufficient as of yet. In this study we confirm earlier findings that CMV exacerbates the atherosclerotic process in apoE knockout mice ${ }^{1.21}$ and we present new evidence demonstrating that CMV infection stimulates an already ongoing inflammatory process in the atherosclerotic vascular wall thereby exacerbating lesion formation in the long run.

\section{MATERIALS AND METHODS}

\section{Mice}

C57BL/6J mice and apoE knockout mice on a C57BL/6J background were obtained from Broekman, Someren, the Netherlands. Housing and care of the animals, and all the procedures used in these studies were approved by the Ethical Committee for the Use of Experimental Animals of the institution, and 
conform with the Guide for the Care and the Use of Laboratory Animals, published by the US National Institute of Health (NIH Publication No. 85-23, revised 1985). The apoE knockout animals were fed ad libitum on a standard mouse chow diet (SRM-A, Hope Farms). C57BL/6J mice, which only develop atherosclerosis on a western type of diet, were put on a high fat/high cholesterol diet containing $15 \%$ cacao butter, $0.5 \%$ cholate, $1 \%$ cholesterol, $40.5 \%$ sucrose, $10 \%$ corn starch, $1 \%$ corn oil and $4.7 \%$ cellulose starting at 4 weeks of age.

\section{Virus}

The Smith strain of mouse CMV (MCMV, kindly provided by Dr. J. Neyts, Rega Institute, University of Leuven, Belgium) was used for inoculation of the mice. A pool of homogenized salivary glands, derived from infected BALB/c mice, was used for all experiments. Mock infections were performed with sterile PBS.

\section{Inoculation of the mice}

Two infection protocols were used. The apoE knockout mice were MCMV( $5 \times 10^{4}$ plaque forming units) or mock-infected intraperitoneally at the age of 8 weeks and sacrificed at 2 or 20 weeks post infection (p.i.). The C57BL/6J mice were either MCMV- or mock-infected at the age of 16 weeks and sacrificed 2 weeks later. These time points of infection were chosen to assure that both mice were in the initial phase of the atherosclerotic process when infected.

\section{Tissue collection}

Prior to sacrifice the mice were anaesthetized with a weight-adjusted dose of pentobarbital (Nembutal ${ }^{\circledR}$, Sanofi Sante B.V., Maassluis, the Netherlands). Blood was collected by left ventricular puncture for determination of lipid profiles and MCMV antibody titers. Then the arterial tree was perfused at $100 \mathrm{mmHg}$ with PBS followed by $1.85 \%$ PBS-buffered formaldehyde, both containing 0.1 $\mathrm{mg} / \mathrm{ml}$ sodium-nitroprusside (Merck, Darmstadt, Germany) via a catheter introduced into the left ventricular apex. Subsequently, the aortic arch (apoE knockout, 2 and 20 weeks p.i.) or the heart with aortic sinus (apoE knockout and C57BL/6J, 2 weeks p.i.) were isolated and fixed overnight in $3.7 \%$ PBSbuffered formaldehyde. The hearts were prepared for sectioning as described previously ${ }^{39}$ and as well as the aortic arches embedded in paraffin. From the aortic arch longitudinally sections were cut while from the aortic sinuses crosssections were used for further analysis. Thickness of all sections was $4 \mu \mathrm{m}$.

Additionally, 20 apoE knockout mice were sacrificed at 2 weeks post infection in order to collect organs for MCMV detection by PCR. These mice were perfused with PBS without $0.1 \mathrm{mg} / \mathrm{ml}$ sodium-nitroprusside and subsequently carotid arteries, abdominal aorta and aortic bifurcation with iliac arteries were removed. Carotid arteries, abdominal aorta and aortic bifurcation with iliac arteries were pooled. All organs were snap frozen in liquid nitrogen and stored at $-70^{\circ} \mathrm{C}$ until further use.

\section{Morphometrical and immunohistochemical characterization of the lesions}

At three different levels (aortic arch, distance between two consecutive longitudinal sections was $40 \mu \mathrm{m}$ ) or at five different levels (aortic sinus, distance between two consecutive cross-sections was $40 \mu \mathrm{m}$ ), the atherosclerotic lesion 
type was determined in hematoxylin-eosin-stained sections. The lesions were classified according to the guidelines given by the American Heart Association ${ }^{46}$ and the final score of a lesion was the highest observed lesion type at different levels.

The lesion area was determined in the above described hematoxylin-eosin stained sections by measuring the area of each lesion using a microscope coupled to a computer-assisted morphometry system (ANALYSIS ${ }^{\circ}$, Soft Imaging System $\mathrm{GmbH}$, Germany). For the aortic sinuses the measured lesion area was corrected for lumen area. For every mouse, the mean lesion area was calculated. Thereafter lesions from mock- and MCMV-infected mice were compared. For further characterization of the atherosclerotic lesions, aortic tissue sections containing the highest lesion type and/or the highest number of lesions were immunolabeled with monoclonal antibodies against smooth muscle cells (mouse anti-SM- $\alpha$-actin, DAKO, Glostrup, Denmark) or endothelial cells (rabbit anti-von Willebrand factor, DAKO, Denmark). Immunostaining was performed according to conventional methods with biotin-labeled secondary antibodies and 3,3' diaminobenzidine as a chromogen. For smooth muscle cells an additional mouse-on-mouse immunodetection kit (MOM-kit, Vector Laboratories Inc.) was used to block a-specific staining of mouse monoclonal antibodies on mouse tissues. For smooth muscle cells, the smooth-muscle- $\alpha$ actin positive area was expressed as percentage of the total lesion area. For endothelial cells, the percentage of lesion surface covered by an endothelial cell layer was determined and compared between mock- and MCMV-infected mice. Scoring was performed by impartial investigators and intra-observer variability was less than $10 \%$.

\section{Inflammatory responses in aortic lesions}

Sections with the highest lesion score were immunolabeled with antibodies against T lymphocytes (rabbit anti-human CD3, DAKO, Glostrup, Denmark) or monocytes/macrophages (rat anti-mouse F4/80, DAKO, Denmark). Sections used for detection of T cells were preincubated with pepsin $(0.1 \mathrm{mg} / \mathrm{ml}$ in $0.1 \mathrm{~N}$ $\mathrm{HCl}$ ) for $30 \mathrm{~min}$. The number of $\mathrm{T}$ cells was counted and expressed as percentage of the total number of cells per lesion. For macrophages, the percentage of the total lesion area staining positive for macrophages was determined for every lesion type.

\section{DNA detection by PCR}

DNA was isolated from organs using the Wizard genomic DNA purification kit (Promega) according to the manufacturer. MCMV specific PCR was performed as described previously with slight modifications ${ }^{3}$. Briefly, one $\mu \mathrm{g}$ of the isolated DNA was subjected to PCR in a total volume of $50 \mu \mathrm{l}$. To check for the presence of PCR inhibitors, each sample was also spiked with 100 copies of plasmid p189. This plasmid contains nucleotides 180,551 to 180,913 of the MCMV Smith genome (GenBank accession number U68299), which include the primer sequences. The reaction mixture contained $0.2 \mu \mathrm{M}$ of each primer, 10 $\mathrm{mM}$ Tris $\mathrm{HCl} \mathrm{pH} 8.5,50 \mathrm{mM} \mathrm{KCl}, 3.5 \mathrm{mM} \mathrm{MgCl}, 0.2 \mathrm{mM}$ dNTPs, 1.25 units of HotStarTaq DNA polymerase (Qiagen, Leusden, the Netherlands). The reaction mixtures were initially incubated at $95^{\circ} \mathrm{C}$ for $15 \mathrm{~min}$ to activate the HotStarTaq enzyme. Subsequently, 40 amplification cycles were performed. Each cycle 
consisted of denaturation at $96^{\circ} \mathrm{C}$ for $30 \mathrm{~s}$, annealing at $58^{\circ} \mathrm{C}$ for $1 \mathrm{~min}$, and extension at $72^{\circ} \mathrm{C}$ for $1 \mathrm{~min}$. The amplification products were analyzed by electrophoresis in a $1.5 \%$ ethidium bromide-stained agarose gel. This PCR test is able to reproducibly detect ten copies of $\mathrm{p} 189$. Positive PCR results were confirmed by Southern blotting using digoxigenin (DIG)-labeled p189 DNA as a probe. For this purpose, the DIG DNA labeling kit and the DIG luminescent detection kit (Roche Molecular Biochemicals, Almere, the Netherlands) were used as recommended by the manufacturer.

\section{MCMV antibody detection by indirect immunofluorescence}

The presence of MCMV antibodies in the MCMV- and mock-infected apoE knockout mice was detected using an indirect immunofluorescence technique. Mouse embryonic fibroblast (MEF) monolayers were infected with MCMV at a multiplicity of infection of 0.1 . After an incubation of three days the cell monolayers were fixed with $96 \%$ methanol during $10 \mathrm{~min}$. The cells were incubated for one hour with 1:10 dilutions in PBS of plasma of the mice to reveal the presence of antibodies against MCMV. Antibodies were detected using FITC-conjugated rabbit anti-mouse immunoglobulin (DAKO, Denmark). Non-infected MEF monolayers were used as controls.

\section{Determination of lipid profile}

Total plasma cholesterol and triglyceride concentrations were measured in plasma of MCMV-infected and control mice by a Beckman Synchron CX Sytem (Beckman Coulter Inc., Fullerton, USA). Blood was collected by retro-orbital puncture every two weeks during a period of 16 weeks p.i. and/or at the day of sacrifice by left ventricular puncture.

\section{Statistical analysis}

Data were expressed as mean \pm S.E.M. One-sided nonparametric analysis were performed for statistical significance with the Mann-Withney U-test to unravel differences between MCMV- and mock-infected mice at different time points p.i. concerning $T$ lymphocyte influx in lesions. A one-sided parametric Student's $t$-test was used to compare smooth muscle cell number, endothelial cell number and macrophage influx in aortic lesions and lesion area in the aorta between MCMV- and mock-infected mice at different time points p.i. A one-way ANOVA with the Bonferroni correction was used to compare the plasma cholesterol and triglyceride levels between MCMV- and mock-infected mice. Differences were regarded to be statistically significant at a value of $P<0.05$.

\section{RESULTS}

\section{Lesion characterization}

In apoE knockout mice early lesions, i.e. lesion type I to III, were observed in both the aortic arch and the aortic sinus at the age of 10 weeks (Figs. 1 B-D). At a later time point ( 28 weeks) also complex lesions (type IV and V) were present (Figs. $1 \mathrm{E}$ and F). In the 18-week-old C57BL/6J mice type II and III lesions were present (Figs. $2 \mathrm{~B}$ and $\mathrm{C}$ ). No plaque rupture was observed in all mice. Type I lesions, also called "initial lesions", were defined as lesions 


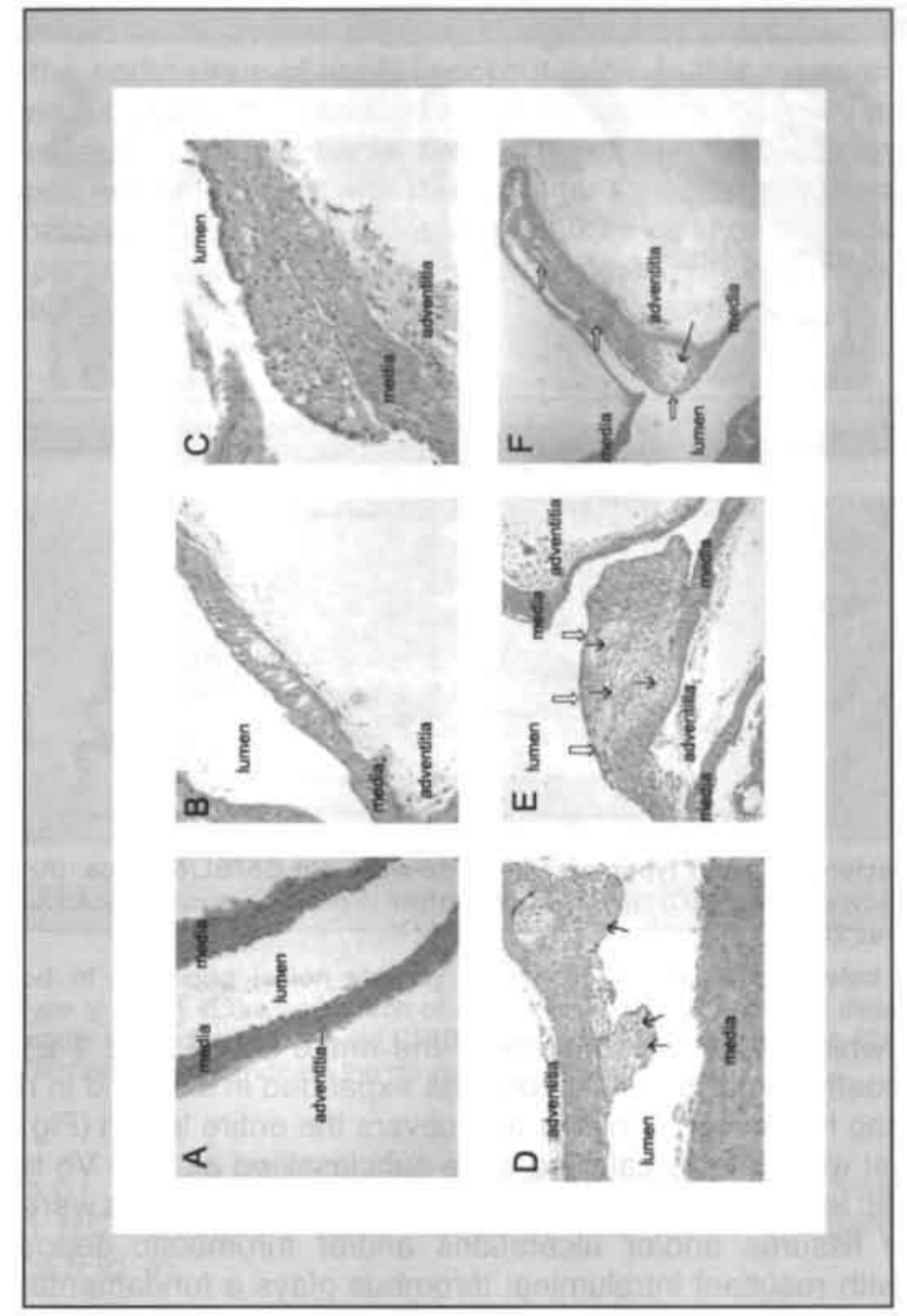

Fig. 1. Atherosclerotic lesion types present in 28-week-old apoE knockout mice. (A) nondiseased aortic wall, (B) type I lesion, (C) type II lesion, (D) type III lesion, (E) type IV lesion, (F) type V lesion. Thin arrows indicate extracellular lipid pools (type III) or lipid core (type IV and V) and open arrows indicate the fibrous cap. Magnification was $200 x$ for type I-IV or $40 x$ for type V.

containing isolated macrophage foam cells in the media (Fig. 1 B) ${ }^{46}$. Type II lesions ("fatty streaks") were defined as lesions consisting primarily of layers of macrophage foam cells which protrude in the lumen (Figs. $1 \mathrm{C}$ and $2 \mathrm{~B}$ ). The "preatheroma", this is the type III lesion, is the lesion type that is potentially symptom-producing and forms the intermediate form between the early lesion types (type I and II) and the more advanced lesion types (type IV to VI). It contains lipid-laden cells and in addition scattered collections of extracellular lipid droplets (Figs. 1 D and 2 C). When these little extracellular lipid pools are aggregated and form a larger, confluent lipid core the lesion is called type IV lesion, the atheroma". Additionally these type of lesions can contain a thin 


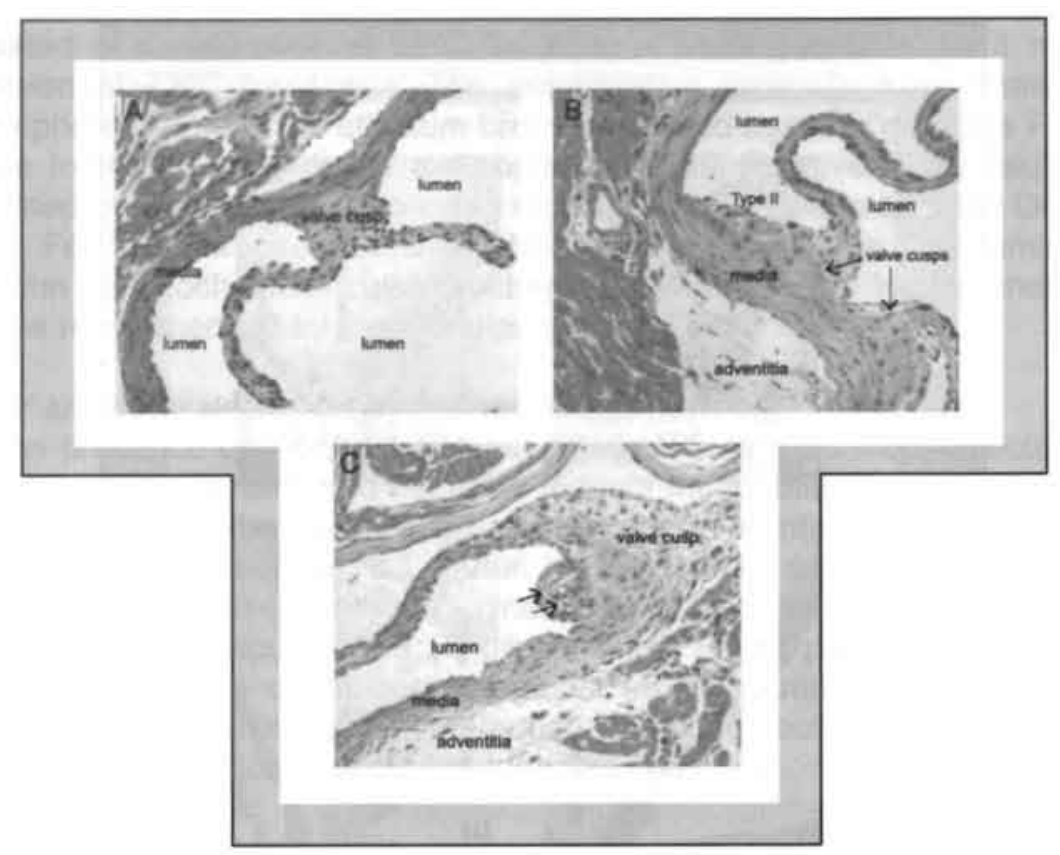

Fig. 2. Atherosclerotic lesion types present in 16-week-old C57BL/6J mice. (A) non-diseased aortic sinus, (B) type II lesion, (C) type III lesion. Arrows in panel C indicate extracellular lipid pools. Magnification was 200x.

fibrous cap which often does not cover the entire lesion (Fig. 1 E). In type $V$ lesions ("fibroatheroma") the lipid core has expanded in size and in number and the fibrotic cap has become thicker and covers the entire lesion (Fig. 1 F). Type $\mathrm{V}$ lesions that were largely calcified were subclassified as type $\mathrm{Vb}$ lesions, also called "calcific lesions". "Complicated lesions" or type VI lesions were defined as lesions with fissures and/or ulcerations and/or thrombotic deposits. Lesion "disruption with resultant intraluminal thrombus plays a fundamental role in the pathogenesis of unstable symptoms of coronary artery disease. The degree of lesion disruption determines the nature of the ensuing clinical state. If only the endothelial surface of the lesion is disrupted, the thrombogenic stimulus is limited, and at the most there is mural thrombus, without symptoms. If the disruption is deeper, a transient occlusion (i.e.lasting minutes) may take place and may be repetitive and cause ischemia ${ }^{10,11}$. Finally, if the disruption is very deep or ulceration exposes the lipid core, collagen, tissue factor and other elements, a thrombotic occlusion that is relatively persistent (i.e. 2-4 h or longer) may result in acute myocardial infarction ${ }^{12}$. Nonetheless, this type of lesion was never observed in our mice.

\section{Effect of MCMV infection on the atherosclerotic process in apoE knockout mice during the chronic phase of infection}

The effect of MCMV infection on the atherosclerotic process in the aortic arch of apoE knockout mice was initially studied at 20 weeks p.i. This time point was chosen in accordance with the study of Hsich et al. ${ }^{21}$ who found that after 
14 weeks mean aortic lesion area was significantly increased after MCMV infection in the aortic sinus of apoE knockout mice. In this experiment however no study was executed on lesion composition and inflammatory influx and no data were available on the aortic arch. Therefor in our experiments aortic arches of apoE knockout mice were analyzed for lesion composition, lesion size and inflammatory influx. Lesion size was measured as shown in figs. $3 \mathrm{~A}$ and $\mathrm{B}$; the luminal part of the lesion was measured as lesion area and the medial part was not taken into consideration.

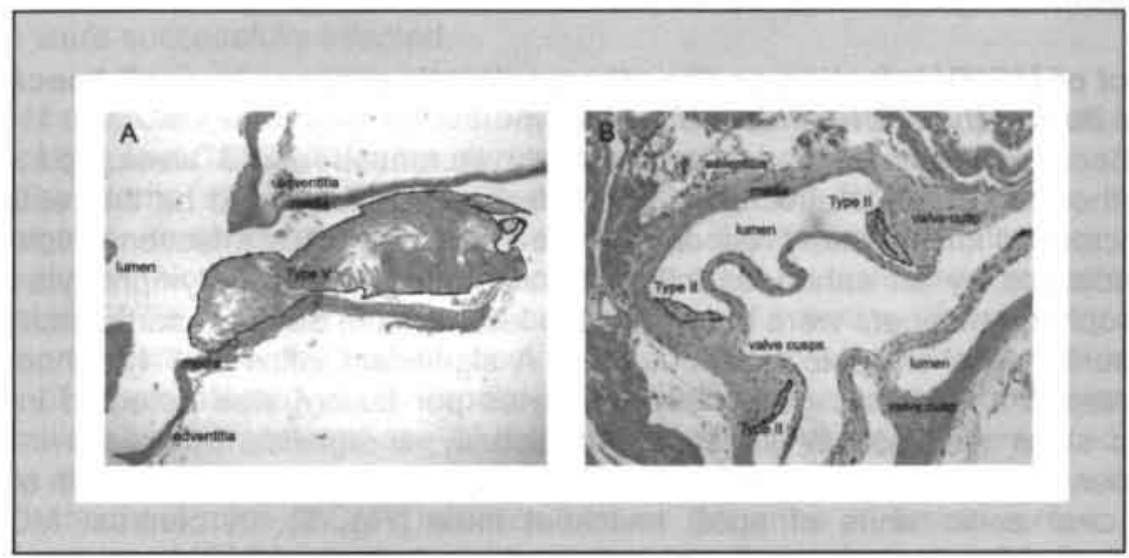

Fig. 3. Method of analyzing lesion size by means of a computer-assisted morphometry system. (A) Type V lesion in the aortic arch of a 28-week-old apoE knockout mouse, (B) Type II lesions in the aortic sinus of a 16-week-old C57BL/6J mouse. Magnification was $40 \mathrm{x}$ for panel A or $100 x$ for panel B. Contour lines indicate the measured lesion area.

At 20 weeks p.i. (chronic phase) a significant increase in mean lesion area was observed in MCMV-infected apoE knockout mice when compared to mockinfected mice (Fig. 4).

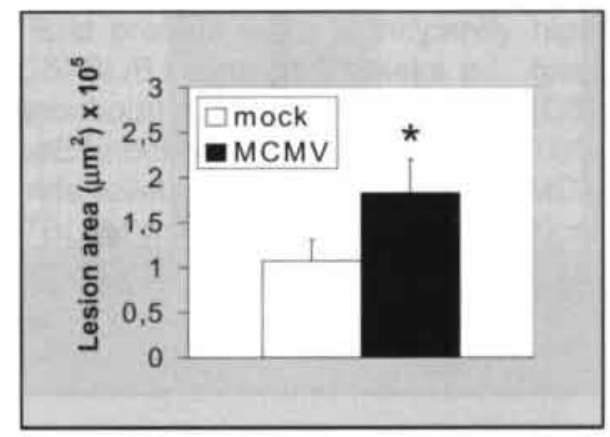

Fig. 4. Effect of MCMV infection on mean lesion area in the aortic arch from 28-week-old apoE knockout mice. ( $\left(^{*}\right) P<0.05$ when compared between mock- and MCMV-infected mice. Data are expressed as mean \pm S.E.M. 
This significant increase in mean lesion area could to a large extent be attributed to a significant increase in type $V$ lesion area $\left(5.8 \times 10^{5} \mu \mathrm{m}^{2} \pm 1.6 \mathrm{x}\right.$ $10^{5}$ [MCMV] vs. $2.6 \times 10^{5} \mu \mathrm{m}^{2} \pm 0.7 \times 10^{5}$ [mock], $P<0.05$ ). On the other hand, MCMV infection had no influence on lesion composition. More precisely, all lesions were covered with endothelial cells and the content of smooth muscle cells (expressed as percentage of the total lesion area) was $37.4 \% \pm 5.6$ in the MCMV-infected mice compared to $33.9 \% \pm 4.6$ in the mock-infected mice. Furthermore, the numbers of T lymphocytes or macrophages in the aortic arch lesions, as markers of the inflammatory process, were not significantly different between both groups at 20 weeks p.i.

\section{Effect of MCMV infection on the atherosclerotic process in apoE knockout mice during the acute phase of infection}

Because lesion size was significantly increased at 20 weeks p.i., we hypothesized that this effect of MCMV infection possibly could be the result of an increased inflammatory response in the lesion early after infection which can be indicated by an enhanced influx of inflammatory cells. T lymphocyte and macrophage numbers were determined in lesions from both the aortic arch and the aortic sinus of apoE knockout mice. A significant influx of T lymphocytes (expressed as percentage of $T$ lymphocytes per lesion) was detected in the aortic sinus after MCMV infection. Additionally, a significant increase in the number of lesions positive for T lymphocyte staining was observed in both aortic arch and aortic sinus of apoE knockout mice (Fig. 5). In contrast MCMV infection did not result in an increased influx of macrophages in both aortic sinus and aortic arch.

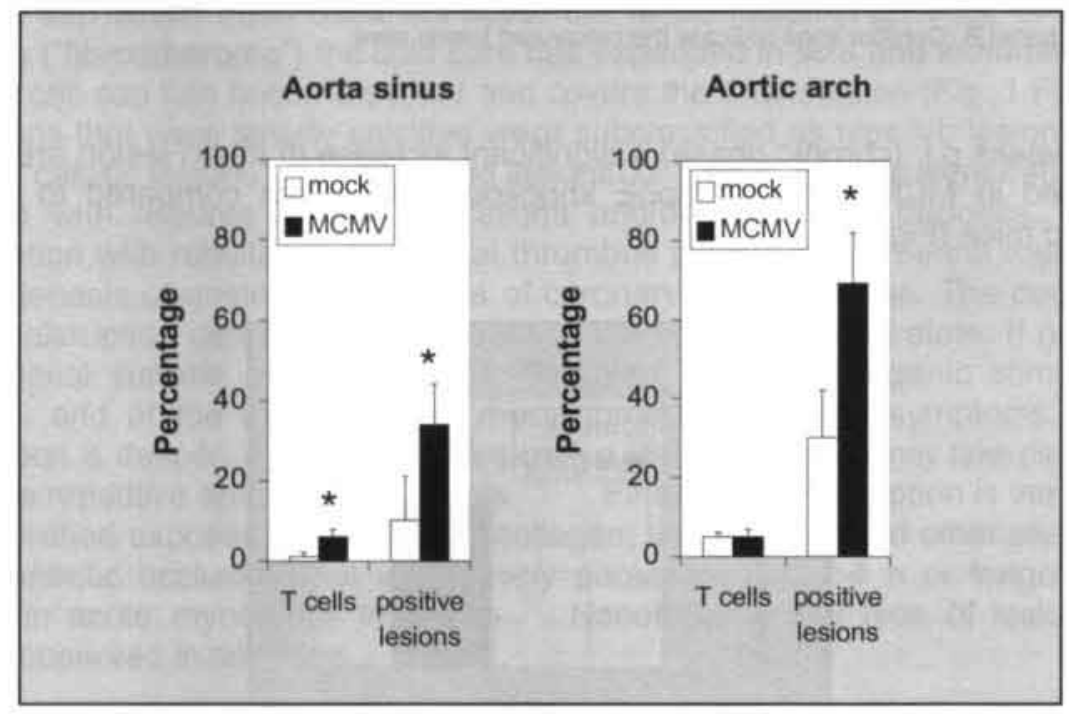

Fig. 5. Effect of MCMV infection on the T lymphocyte influx in aortic sinus lesions (left panel) and aortic arch lesions (right panel) from 10-week-old apoE knockout mice. "T cell" stands for the number of $T$ cells expressed as percentage of the total number of cells per lesion. "Positive lesions" stands for the percentage of lesions positive for T lymphocyte staining. (") $P<0.05$ when compared between mock- and MCMV-infected mice. Data are expressed as mean \pm S.E.M. 
No effect was seen on lesion area or cell composition in apoE knockout mice during the acute phase of infection. All lesions were covered by endothelial cells and the percentage of smooth muscle positive area remained equal in mock- and MCMV-infected mice (aortic arch: $0.29 \% \pm 0.09$ [MCMV] vs. $1.42 \% \pm 0.43$ [mock], aortic sinus: $1.28 \% \pm 0.61$ [MCMV] vs. $0.67 \% \pm 0.48$ [mock]).

Although our PCR technique allowed us to reproducibly detect ten copies of the virus DNA, we failed to detect MCMV DNA in the vessel wall of the apoE knockout mice. However, MCMV antibodies were detected in the plasma of MCMV-infected mice but not in the plasma of mock-infected mice indicating that mice were successfully infected.

\section{Effect of MCMV infection on lesion development in aortic sinuses of apoE knockout and C57BL/6J mice during the acute phase of infection}

The aortic sinus of C57BL/6J mice was studied for lesion size, lesion composition (smooth muscle cells and endothelial cells) and inflammatory influx 2 weeks p.i. No effect of MCMV infection was seen on lesion size in the aortic sinus of $\mathrm{C} 57 \mathrm{BL} / 6 \mathrm{~J}$ mice during the acute phase of infection. When comparing the aortic sinus lesion area of mock-infected C57BL/6J mice with the lesion area of mock-infected apoE knockout mice, we observed that both types of mice were in the same phase of the atherosclerotic process. More precisely, lesion area was comparable in both types of mice (data not shown). As in the apoE knockout mice, MCMV infection had no influence on lesion composition. Furthermore, MCMV infection did not alter the T lymphocyte influx in aortic sinuses of C57BL/6J during the acute phase of infection. This observation is in marked contrast with the significantly increased $\mathrm{T}$ lymphocyte influx in apoE knockout mice, although this mouse strain was breeded on a C56BL/6J background. In addition, as in apoE knockout mice no effect of MCMV infection was seen on the macrophage influx in the lesions.

\section{Effect of MCMV infection on the plasma lipid profiles}

Plasma cholesterol and triglyceride levels were determined in apoE knockout mice every two weeks during a period of 16 weeks by retro-orbital puncture. In C57BL/6J mice, plasma lipids were only determined 2 weeks p.i. As expected plasma lipid profiles were significantly higher in apoE knockout mice compared with C57BL/6J mice at 2 weeks p.i., (plasma cholesterol: 13.8 $\mathrm{mmol} / \mathrm{l} \pm 0.5$ [apoE knockout] vs. $7.7 \mathrm{mmol} / \mathrm{l} \pm 0.3$ [C57BL/6J], triglycerides: $5.10 \mathrm{mmol} / \mathrm{l} \pm 0.67$ [apoE knockout] vs. $0.26 \mathrm{mmol} / \mathrm{l} \pm 0.05$ [C57BL/6J], $P<0.05$ ). Cholesterol or triglyceride levels were not affected by MCMV infection neither in apoE knockout or C57BL/6J mice. Moreover, no significant further elevation of lipid levels was observed in apoE knockout mice over the rest of the experimental period.

\section{DISCUSSION}

In the present study we demonstrate that a single MCMV infection stimulates T lymphocyte influx in both the aortic arch as well as the aortic sinus in apoE knockout mice during the acute phase of the infection. Furthermore, 
mean aortic arch lesion size was significantly increased during the chronic phase of the infection. However, no virus DNA could be demonstrated in the vascular wall of apoE knockout mice 2 weeks p.i. This observation questions whether the enhanced plaque formation is triggered by a direct MCMV effect on the atherosclerotic lesion. It is implied that a MCMV infection activates a systemic inflammatory response thereby exacerbating atherosclerotic plaque formation in the long run.

Since the original finding by Minick and colleagues that an avian herpesvirus (Marek's disease virus) could induce atherosclerosis in chickens, the role of CMV and other herpesviruses in the progression of atherosclerosis has gained considerable interest ${ }^{32}$. Furthermore, sero-epidemiological studies pointed out an association between pathogen-specific lgG antibodies and atherosclerosis and high CMV antibodies titers were more frequent in patients undergoing surgery for atherosclerotic disease than in matched control patients 1. 29 . Furthermore, both early and late regions of the CMV DNA genome could be amplified from femoral and abdominal arterial samples from patients suffering from grade III atherosclerosis ${ }^{19}$.

Several direct mechanisms have been suggested by which CMV may contribute to the atherosclerotic process. In vitro studies demonstrated thrombin formation and increased adherence of platelets and granulocytes in human endothelial cells infected with herpesvirus ${ }^{44}$. This increased adherence may be the result of enhanced adhesion molecule expression in endothelial cells following CMV infection ${ }^{40}$. Additionally, cytomegalovirus has been shown to stimulate vascular smooth muscle cell migration and proliferation in vitro $47,48,50$ and in vivo by gene transfection in normal carotid arteries ${ }^{48}$. Both smooth muscle cell proliferation and migration from the media to intima are likely to be crucial events in the advanced phase of the atherosclerotic process. Nonetheless in our experiment CMV infection did not affect smooth muscle cells number both in the acute phase as in the chronic phase of the infection. This indicates that in this model the MCMV-mediated increase in mean lesion area is not mediated by an increased smooth muscle cell migration or proliferation.

However, CMV may also have an indirect effect on the atherosclerotic process. In the present as well as in other studies ${ }^{45.49}$ no replicating virus could be detected in the vessel wall 2 weeks p.i. This questions whether the observed effects were induced by a direct effect of CMV on the atherosclerotic vascular wall. It can be hypothesized that effects, other than those caused by local infection of the vessel wall are involved in the virus-induced effect on atherosclerosis. CMV infection may have induced a systemic inflammatory response which leads to an increased influx of inflammatory cells in the diseased vessel wall as seen in our study in the apoE knockout mice. It is tempting to speculate that the presence of these cells in the vessel wall has contributed, via production of active compounds such as cytokines ${ }^{8,13-15}$, to the enhancement of atherosclerotic lesion formation in the chronic phase of the infection ${ }^{22,24}$. Another possibility is that systemic CMV infection stimulates the production of circulating cytokines ${ }^{49}$ which in turn can exacerbate the ongoing inflammation in the diseased vessel wall.

In the present study, two strikingly different observations were made in apoE knockout mice during the chronic and acute phase of MCMV infection. In the chronic phase mean lesion size was significantly increased in apoE 
knockout mice without alterations in inflammatory cell influx. On the other hand, in the acute phase the main observation was an increased T lymphocyte influx without any alteration in lesion size. For many decades atherosclerotic lesions have been considered as accumulations of lipids, accompanied by smooth muscle cell proliferation and migration. However, recent new insights indicated atherosclerosis as an inflammatory disease ${ }^{41}$. Inflammatory cells are major components of the atherosclerotic lesion with activated macrophages and $T$ lymphocytes already present in the early "fatty streaks" ${ }^{17}$. These inflammatory cells exert a variety of pro-atherogenic actions including the induction of adhesion molecules and the production of a divers spectrum of chemokines, cytokines, proteolytic enzymes and growth factors. Recently, the importance of T lymphocytes in lesion development has been demonstrated by Mach et al. ${ }^{27}$ They demonstrated a reduction in early lesion development in LDLrec knockout mice after treatment with an antibody against CD154. Furthermore, Lutgens et al. ${ }^{25}$. 26 showed that advanced lesions in apoE/CD145 knockout mice or after CD40L antibody treatment displayed a more stable plaque phenotype further emphasizing the role of $\mathrm{T}$ lymphocytes in plaque development. Therefore we speculate that the increased influx of $T$ lymphocytes, as observed in our experiments early after MCMV infection, may play a prominent role in the enlargement of plaque area at later stages. Interestingly, a similar prominent role for lymphocytes was observed in the development of early atherosclerotic plaques in the aorta of BALB/c mice following MCMV infection ${ }^{4}$. The mechanism by which the increased $T$ lymphocyte influx contributes to plaque enlargement has to be elucidated. Burnett et al. ${ }^{7}$ demonstrated a significant increase in serum IFN $\gamma$ levels and lesion area in apoE knockout mice following MCMV infection. This cytokine has been demonstrated to be involved in the progression of atherosclerosis ${ }^{16}$ and transplant arteriosclerosis ${ }^{33,42}$ most likely by activating monocytes/macrophages and T lymphocytes, providing a possible mechanism by which activated T lymphocytes after MCMV infection induce an exacerbation of the atherosclerotic process in the chronic phase of the infection.

Plasma lipid profiles were not significantly different between both groups over the whole experimental period, a finding that is in line with a previous report by Hsich et al. ${ }^{21}$ Nonetheless, since inflammation and infection have been shown to induce LDL oxidation in vivo ${ }^{31}$, we can not exclude that MCMV infections change the ratio between different lipid subfractions over time thereby increasing the plasma content of pro-atherogenic fractions. Further experiments are needed to establish whether CMV infections result in an altered lipid metabolism, which may contribute to the progression of the disease.

In this experiment we used either C57BL/6J or apoE knockout mice with a $\mathrm{C} 57 \mathrm{BL} / 6 \mathrm{~J}$ background. Although the C57BL/6J mouse strain is one of the most atherosclerosis-sensitive inbred strains ${ }^{39}$ this strain is rather insensitive for MCMV disease ${ }^{6}$. This may explain why CMV infection only had a mild effect on the atherosclerotic process in apoE knockout mice. The reason for the absence of an effect on the inflammatory response in C57BL/6J mice during the acute phase following MCMV infection is unknown for the moment. However, recent findings suggest that mouse strains displaying high levels of plasma lipids, such as the apoE and LDLrec knockout mouse strain, may be more susceptible for bacterial infections and inflammation ${ }^{9.36}$. It remains to be established whether the same holds true for viral infections. 
In summary our results show that CMV infection aggravates the atherosclerotic process in apoE knockout mice in the chronic phase of the infection by inducing an acute inflammatory response. No effects were observed on early lesion formation in C57BL/6J mice (Fig. 6). Since CMV could not be detected in the vascular wall it is unlikely that the exacerbating effect of CMV infection seen in our experiments is caused by a direct effect of the infection. However, the induced effect on the atherosclerotic process by CMV infection can be addressed to an indirect effect of the virus on the vascular wall i.e. a transient increased influx of $T$ lymphocytes into the lesions shortly after infection. Further studies are on their way to analyze the $T$ lymphocyte activation state and their cytokine production profile after CMV infection.

\begin{tabular}{|c|c|c|}
\cline { 2 - 3 } \multicolumn{1}{c|}{} & $\begin{array}{c}\text { ApoE knock-out } \\
\text { (C57BL/6J background) } \\
\text { Chow diet }\end{array}$ & $\begin{array}{c}\text { C57BL/6J } \\
\text { Atherogenic diet } \\
\text { (starting at 4 weeks) }\end{array}$ \\
\hline $\begin{array}{c}\text { MCMV/mock } \\
\text { infection at }\end{array}$ & 8 weeks & 20 weeks \\
\hline Sacrifice & 2 weeks p.i. 20 weeks p.i. & 2 weeks p.i. \\
\hline
\end{tabular}

\begin{tabular}{|c|c|c|c|}
\hline Lesion area & $\approx$ & $\uparrow \uparrow$ & $\approx$ \\
\hline $\begin{array}{l}\text { \# endothelial and } \\
\text { smooth muscle } \\
\text { cells }\end{array}$ & $\approx$ & $\approx$ & $\approx$ \\
\hline \# macrophages & $\approx$ & $\approx$ & $\approx$ \\
\hline \# T lymphocytes & $\uparrow \uparrow$ & $\approx$ & $\approx$ \\
\hline $\begin{array}{c}\text { Plasma CMV } \\
\text { antibodies }\end{array}$ & Yes & Yes & n.d. \\
\hline $\mathrm{CMV}$ in lesions & No & No & n.d. \\
\hline Lipid profile & & & $\approx$ \\
\hline
\end{tabular}

Fig. 6. Summary of the study design and results. $=$ : no difference between MCMV-and mockinfected mice; $\uparrow$ : significant increase compared to mock-infected mice; n.d.: not determined.

\section{ACKNOWLEDGEMENTS}

We would like to thank our colleagues from the Central Laboratory Animal Unit for logistic support and P. Terporten for statistical advise. Also special thanks to M.M. Hulsbosch for the MCMV PCR data. 
1. Adam E, Melnick JL, Probtsfield JL, Petrie BL, Burek J, Bailey KR, McCollum CH, DeBakey ME. High levels of cytomegalovirus antibody in patients requiring vascular surgery for atherosclerosis. Lancet. 1987:2:291-293.

2. Alber DG, Powell KL, Vallance P, Goodwin DA, Grahame Clarke C. Herpesvirus infection accelerates atherosclerosis in the apolipoprotein E-deficient mouse. Circulation. 2000;102:779785.

3. Balthesen M, Messerle M, Reddehase MJ. Lungs are a major organ site of cytomegalovirus latency and recurrence. $J$ Virol. 1993;67:5360-5366.

4. Berencsi K. Endresz V, Klurfeld D, Kari L, Kritchevsky D, Gonczol E. Early atherosclerotic plaques in the aorta following cytomegalovirus infection of mice. Cell Adhes Commun. 1998;5:39-47.

5. Boehler A, Schaffner A, Salomon F, Keusch G. Cytomegalovirus disease of late onset following renal transplantation: a potentially fatal entity. Scand J Infect Dis. 1994;26:369-373.

6. Bukowski JF, Woda BA, Welsh RM. Pathogenesis of murine cytomegalovirus infection in natural killer cell-depleted mice. J Virol. 1984:52:119-128.

7. Burnett MS, Gaydos CA, Madico GE, Glad SM, Paigen B, Quinn TC, Epstein SE. Atherosclerosis in apoE knockout mice infected with multiple pathogens. I Infect Dis. 2001:183:226-231.

8. Carlquist JF, Edelman L, Bennion DW, Anderson JL. Cytomegalovirus induction of interleukin6 in lung fibroblasts occurs independently of active infection and involves a $G$ protein and the transcription factor, NF-kappaB. J Infect Dis. 1999:179:1094-1100.

9. de Bont N, Netea MG, Demacker PN, Verschueren I, Kullberg BJ, van Dijk KW, van der Meer JW, Stalenhoef AF. Apolipoprotein E knock-out mice are highly susceptible to endotoxemia and Klebsiella pneumoniae infection. J Lipid Res. 1999;40:680-685.

10. Falk E. Morphologic features of unstable atherothrombotic plaques underlying acute coronary syndromes. Am J Cardiol. 1989;63:114E-120E.

11. Falk E. Why do plaques rupture? Circulation. 1992;86:11130-42.

12. Fuster V. Badimon L, Cohen M. Ambrose JA, Badimon JJ, Chesebro J. Insights into the pathogenesis of acute ischemic syndromes. Circulation. 1988;77:1213-1220.

13. Geist LJ, Monick MM, Stinski MF, Hunninghake GW. The immediate early genes of human cytomegalovirus upregulate expression of the interleukin-2 and interleukin-2 receptor genes. Am J Respir Cell Mol Biol. 1991; 5:292-296.

14. Geist LJ, Monick MM, Stinski MF, Hunninghake GW. The immediate early genes of human cytomegalovirus upregulate tumor necrosis factor-alpha gene expression. J Clin Invest. 1994:93:474-478.

15. Geist LJ, Dai LY, Cytomegalovirus modulates interleukin-6 gene expression. Transplantation. 1996:62:653-658.

16. Gupta S, Pablo AM, Jiang X, Wang N, Tall AR, Schindler C. IFN-gamma potentiates atherosclerosis in ApoE knock-out mice. J Clin Invest. 1997;99:2752-2761.

17. Hansson GK. Cell-mediated immunity in atherosclerosis. Curr Opin Lipidol. 1997;8:301-311.

18. Heiss G, Sharrett AR, Barnes R, Chambless LE, Szklo M, Alzola C. Carotid atherosclerosis measured by B-mode ultrasound in populations: associations with cardiovascular risk factors in the ARIC study. Am J Epidemiol. 1991;134:250-256.

19. Hendrix MG, Salimans MM, van Boven CP. Bruggeman CA. High prevalence of latently present cytomegalovirus in arterial walls of patients suffering from grade III atherosclerosis. Am J Pathol. 1990;136:23-28.

20. Hofker MH, van Vlijmen BJ, Havekes LM. Transgenic mouse models to study the role of APOE in hyperlipidemia and atherosclerosis. Atherosclerosis. 1998;137:1-11.

21. Hsich E, Zhou YF, Paigen B, Johnson TM, Burnett MS, Epstein SE. Cytomegalovirus infection increases development of atherosclerosis in Apolipoprotein-E knockout mice. Atherosclerosis. 2001:156:23-28.

22. Huber SA, Sakkinen P, Conze D, Hardin N, Tracy R. Interleukin-6 exacerbates early atherosclerosis in mice. Arterioscler Thromb Vasc Biol. 1999;19:2364-2367.

23. Ishibashi S, Brown MS, Goldstein JL, Gerard RD, Hammer RE, Herz J. Hypercholesterolemia in low density lipoprotein receptor knockout mice and its reversal by adenovirus-mediated gene delivery. J Clin Invest, 1993;92:883-893.

24. Lee TS, Yen HC, Pan CC, Chau LY. The role of interleukin 12 in the development of atherosclerosis in ApoE-deficient mice. Arterioscler Thromb Vasc Biol. 1999:19:734-742. 
25. Lutgens E, Gorelik L, Daemen MJ, de Muinck ED, Grewal IS, Koteliansky VE, Flavell RA. Requirement for CD154 in the progression of atherosclerosis. Nat Med. 1999:5:1313-1316.

26. Lutgens E, Cleutjens KB, Heeneman S, Koteliansky VE, Burkly LC, Daemen MJ. Both early and delayed anti-CD40L antibody treatment induces a stable plaque phenotype. Proc Natl Acad Sci USA. 2000:97:7464-7469.

27. Mach F, Schonbeck U, Sukhova GK, Atkinson E, Libby P. Reduction of atherosclerosis in mice by inhibition of CD40 signalling. Nature. 1998;394:200-203.

28. Macher AM, Reichert CM, Straus SE, Longo DL, Parrillo J, Lane HC, Fauci AS, Rook AH, Manischewitz JF, Quinnan GV, Jr. Death in the AIDS patient: role of cytomegalovirus. N Engl J Med. 1983:309:1454.

29. Melnick JL, Adam E, Debakey ME. Cytomegalovirus and atherosclerosis. Eur Heart J. 1993;14 Suppl K:30-38.

30. Melnick JL, Hu C, Burek J, Adam E, DeBakey ME. Cytomegalovirus DNA in arterial walls of patients with atherosclerosis. J Med Virol. 1994:42:170-174.

31. Memon RA, Staprans I, Noor M, Holleran WM, Uchida Y, Moser AH, Feingold KR, Grunfeld C. Infection and inflammation induce LDL oxidation in vivo. Arterioscler Thromb Vasc Biol. 2000;20:1536-1542.

32. Minick CR. Fabricant CG. Fabricant J, Litrenta MM. Atheroarteriosclerosis induced by infection with a herpesvirus. Am J Pathol. 1979;96:673-706.

33. Nagano H, Mitchell RN, Taylor MK, Hasegawa S, Tilney NL, Libby P. Interferon-gamma deficiency prevents coronary arteriosclerosis but not myocardial rejection in transplanted mouse hearts. J Clin Invest. 1997;100:550-557.

34. Nakashima Y, Plump AS, Raines EW, Breslow JL, Ross R. ApoE-deficient mice develop lesions of all phases of atherosclerosis throughout the arterial tree. Arterioscler Thromb. 1994:14:133-140.

35. Neiman P, Wasserman PB, Wentworth BB, Kao GF, Lerner KG, Storb R, Buckner CD, Clift RA, Fefer A, Fass L, Glucksberg H, Thomas ED. Interstitial pneumonia and cytomegalovirus infection as complications of human marrow transplantation. Transplantation. 1973;15:478485.

36. Netea MG, Demacker PN, de Bont N, Boerman OC, Stalenhoef AF, van der Meer JW, Kullberg BJ. Hyperlipoproteinemia enhances susceptibility to acute disseminated Candida albicans infection in low-density-lipoprotein-receptor- deficient mice. Infect Immun. 1997;65:2663-2667.

37. Nicoletti A, Caligiuri G, Hansson GK. Immunomodulation of atherosclerosis: myth and reality. $J$ Intern Med. 2000;247:397-405.

38. Nieto FJ, Adam E, Sorlie P. Farzadegan H, Melnick JL, Comstock GW. Szklo M. Cohort study of cytomegalovirus infection as a risk factor for carotid intimal-medial thickening, a measure of subclinical atherosclerosis [see comments]. Circulation. 1996;94:922-927.

39. Paigen B, Morrow A, Brandon C, Mitchell D, Holmes P. Variation in susceptibility to atherosclerosis among inbred strains of mice. Atherosclerosis. 1985;57:65-73.

40. Ricotta D, Alessandri G, Pollara C, Fiorentini S, Favilli F. Tosetti M, Mantovani A, Grassi M, Garrafa E, Dei Cas L. Muneretto C. Caruso A. Adult human heart microvascular endothelial cells are permissive for non-lytic infection by human cytomegalovirus. Cardiovasc Res. 2001:49:440-448.

41. Ross R. Atherosclerosis--an inflammatory disease. N Engl J Med. 1999;340:115-126.

42. Russell PS, Chase CM, Winn HJ, Colvin RB. Coronary atherosclerosis in transplanted mouse hearts. III. Effects of recipient treatment with a monoclonal antibody to interferon-gamma. Transplantation. 1994:57:1367-1371.

43. Schmitz G, Herr AS, Rothe G. T-lymphocytes and monocytes in atherogenesis. Herz. 1998;23:168-177.

44. Span AH, van Dam Mieras MC, Mullers W. Endert J, Muller AD, Bruggeman CA. The effect of virus infection on the adherence of leukocytes or platelets to endothelial cells. Eur $J$ Clin Invest. 1991:21:331-338.

45. Span AH, Grauls G. Bosman F, van Boven CP. Bruggeman CA. Cytomegalovirus infection induces vascular injury in the rat. Atherosclerosis. 1992;93:41-52.

46. Stary HC, Chandler AB, Dinsmore RE, Fuster V, Glagov S, Insull W. Jr., Rosenfeld ME, Schwartz CJ, Wagner WD, Wissler RW. A definition of advanced types of atherosclerotic lesions and a histological classification of atherosclerosis. A report from the Committee on Vascular Lesions of the Council on Arteriosclerosis, American Heart Association. Circulation. 1995;92:1355-1374. 
47. Streblow DN, Soderberg Naucler C, Vieira J, Smith P, Wakabayashi E, Ruchti F, Mattison K, Altschuler $Y$, Nelson JA. The human cytomegalovirus chemokine receptor US28 mediates vascular smooth muscle cell migration. CELL. 1999;99:511-520.

48. Yonemitsu $Y$, Kaneda $Y$, Komori K, Hirai K, Sugimachi K, Sueishi K. The immediate early gene of human cytomegalovirus stimulates vascular smooth muscle cell proliferation in vitro and in vivo. Biochem Biophys Res Commun. 1997;231:447-451.

49. Zhou YF, Shou M, Guetta E, Guzman R, Unger EF, Yu ZX, Zhang J, Finkel T, Epstein SE. Cytomegalovirus infection of rats increases the neointimal response to vascular injury without consistent evidence of direct infection of the vascular wall. Circulation. 1999:100:1569-1575.

50. Zhou YF, Yu ZX, Wanishsawad C, Shou M, Epstein SE. The immediate early gene products of human cytomegalovirus increase vascular smooth muscle cell migration, proliferation, and expression of PDGF beta-receptor. Biochem Biophys Res Commun. 1999;256:608-613.

51. Zhu JH, Quyyumi AA, Norman JE, Csako G, Epstein SE. Cytomegalovirus in the pathogenesis of atherosclerosis - The role of inflammation as reflected by elevated C-reactive protein levels. J Am Coll Cardiol. 1999;34:1738-1743. 



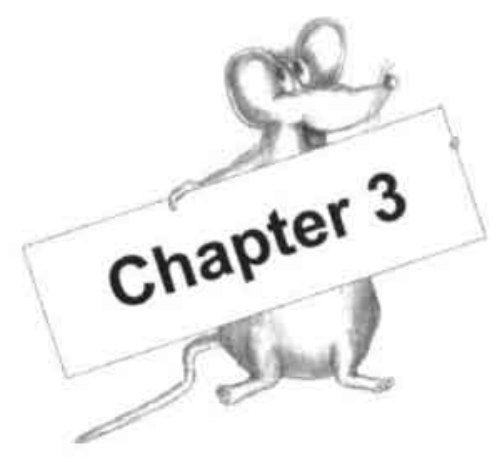

Improved detection and quantification of mouse cytomegalovirus by real-time PCR

INGE VLIEGEN, SELMA HERNGREEN, GERT GRAULS, CATHRIEN BRUGGEMAN, FRANK STASSEN

Department of Medical Microbiology, Cardiovascular Research Institute Maastricht (CARIM), University of Maastricht, the Netherlands

Virus Res, in press 


\section{ABSTRACT}

During latent cytomegalovirus (CMV) infection viral presence cannot be detected by plaque assay. Therefore we assessed the applicability of real-time PCR for temporal determination of virus dissemination in two different mouse strains. Eight-week-old BALB/C and C57BL/6J mice were infected with mouse CMV (MCMV) and sacrificed at 1, 2, 4, 6, 14 and 28 days post infection. Realtime PCR was used to determine MCMV copy number in the heart, bone marrow cells, aorta and blood. In lung, liver, salivary gland and spleen the presence of MCMV was determined both by plaque assay and real-time PCR. In analogy with the plaque assay, the real-time PCR technique revealed higher numbers of MCMV genomic copies in all organs obtained from BALB/C mice when compared with C57BL/6J mice, demonstrating the applicability of the technique. A significant correlation was observed between both assays when a positive test result was seen with both assays. Nonetheless, lower viral titers were found compared to real-time PCR data. Thus, the real-time PCR technique is superior in detecting the presence of MCMV and is therefore well suited for (dose-response) intervention studies aimed at studying virus eradication. 
Cytomegalovirus (CMV) is a widely distributed species specific $\beta$ Herpesvirus which establishes latency after clearance of primary infection ${ }^{7.35}$. In the immuno-competent healthy host, the virus rarely causes a symptomatic infection, while in immuno-compromised patients (organ transplant recipients, AIDS patients) CMV infection is a major cause of morbidity and mortality. Although molecular techniques allow studies on human CMV (HCMV) replication and gene expression in vitro, the species specificity of the virus makes it difficult to perform in vivo studies. Nonetheless, the shared viral and biologic characteristics with HCMV allow murine CMV (MCMV) to be used as a model for human CMV infections to experimentally address specific questions on viral dissemination, latency versus reactivation and pathogenesis.

The large variability in MCMV sensitivity between several inbred mouse strains hinders interpretation of in vivo MCMV infection and dissemination studies. While BALB/c mice have been described to be genetically susceptible to MCMV infection, C57BL/6J mice are rather MCMV resistant ${ }^{2,16,31}$. This difference in susceptibility is controlled by a dominant gene on chromosome 6 called Cmv1 ${ }^{39,40}$ in addition to the contribution of MHC genes ${ }^{10,16}$. Therefore, the best choice performing MCMV infection studies seems to be the BALB/c mouse ${ }^{3,4,23,25-27,31,45}$. However, as the C57BL/6J mouse strain is the main background strain for multiple genetically modified mice, it is worthwhile to investigate the effects of MCMV infection in this particular mouse strain ${ }^{30}$, 34. 3638

The detection and quantification of cytomegalovirus is generally done by a standard plaque assay. Although this assay is specific, it has a low sensitivity and therefore cannot detect presence of virus in low concentrations. It is also possible to quantify CMV by PCR-based techniques. While other (semi-) quantitative PCR techniques have been described ${ }^{17}$, both techniques are timeconsuming and contamination sensitive because of the multiple handlings per sample. Recently, the real-time PCR technique has been developed. This realtime PCR technique is a rapid and reproducible quantitative method for the detection of nucleic acids using a system of thermal cycling, real-time fluorescence detection and subsequent analysis ${ }^{15,19}$. Carry-over contamination is limited because there is no need for endpoint manipulations or multiple dilutions per sample as in the previously described (semi-) quantitative PCR methods. For these reason we decided to set-up a real-time PCR technique for the detection of MCMV. A real-time PCR method for the detection of MCMV has several advantages over the plaque assay including: (1) detection of viral particles in non-replicative form, (2) high sensitivity and (3) precise quantification of cytomegalovirus DNA copies. Consequently, with this technique a correct pattern of viral spread and a correct quantification of viral presence can be determined at all time points.

To our knowledge, this is the first report describing the development and use of real-time MCMV PCR to detect viral presence in various internal organs. To validate the technique we determined dissemination pattern in both a highsensitive mouse strain (BALB/c) and a low-sensitive mouse strain (C57BL/6J). Numbers of DNA copies were quantified and compared between both mouse strains. In addition, plaque assays were performed on "MCMV-prone" organs in 
an attempt to asses relative sensitivities of and correlation between plaque assay and real-time PCR.

\section{MATERIALS AND METHODS}

\section{Virus stocks}

The Smith strain of MCMV (kindly provided by Dr. J. Neyts, Rega Institute, University of Leuven, Belgium) was used in all experiments. The stock of MCMV used for inoculation was prepared by homogenization of salivary glands isolated from $B A L B / c$ mice, which had been infected with $2 \times 10^{4}$ plaque forming units (PFU) of MCMV and sacrificed 1 week post infection (p.i.).

\section{Mice and infection protocol}

Eight-week-old male specific pathogen-free inbred BALB/C and C57BL/6J mice were obtained from Charles River, Someren, the Netherlands. Both strains were maintained under standard housing conditions and had free access to tap water and food. The study protocol was reviewed and approved by the Ethical Committee for the Use of Experimental Animals of the Maastricht University, $\mathrm{BALB} / \mathrm{c}$ and C57BL/6J mice were infected by intraperitoneal injection of $5 \times 10^{3}$ PFU MCMV and sacrificed at $1,2,4,6,14,28$ days p.i. ( $n=4$ per time point).

\section{Tissue collection}

Prior to sacrifice the mice were anaesthetized with a weight-adjusted dose of pentobarbital (Nembutal ${ }^{\oplus}$, Sanofi Sante B.V., Maassluis, the Netherlands) and blood was collected by left ventricular puncture. Then the arterial tree was perfused at $100 \mathrm{mmHg}$ with sterile PBS via a catheter introduced into the left ventricular apex. Subsequently, salivary gland, lung, liver and spleen were removed under aseptic conditions. One part of each organ was immediately frozen in sterile Earle's Minimal Essential Medium (EMEM, BioWhittaker Europe, Verviers, Belgium) supplemented with $2 \%$ NCS (GibcoBRL, Life Technologies LTD, Palsley, Scotland) and stored at $-80^{\circ} \mathrm{C}$ until plaque assay was performed. A second part was collected, snap frozen in liquid nitrogen and stored at $-80^{\circ} \mathrm{C}$ until DNA extraction was performed. In addition, the thoracic arterial tree (aortic arch, carotid arteries and thoracic aorta), bone marrow cells and heart (left/right ventricle and septum) were collected for DNA isolation and stored at $-80^{\circ} \mathrm{C}$. From whole EDTA-treated blood $100 \mu \mathrm{l}$ was added to $900 \mu \mathrm{l}$ NASBA buffer (Organon Teknika B.V., Boxtel, the Netherlands) and stored at $80^{\circ} \mathrm{C}$ until DNA isolation.

\section{Standard MCMV PCR}

DNA was isolated from lung, liver, salivary gland, spleen, heart, aorta and bone marrow cells by using the Wizard genomic DNA purification kit (Promega Benelux B.V., Leiden, the Netherlands) according to the manufacturer. Isolation of DNA from blood samples was carried out according to the method of Boom et al. ${ }^{6}$ MCMV-specific PCR was performed as described previously with slight modifications ${ }^{3}$. Briefly, one $\mu \mathrm{g}$ of the isolated DNA was subjected to PCR in a total volume of $50 \mu \mathrm{l}$. To check for the presence of PCR inhibitors, each sample was spiked with 10 copies of plasmid p189-p155. This plasmid contains 
nucleotides 180,551 to 180,913 of the MCMV Smith genome (Immediate early-1 (IE-1) exon 4, GenBank accession number U68299), which includes the primer sequences, and an additional fragment of $138 \mathrm{bp}$ cloned into the MCMV sequence, corresponding to position 215,968 to 216,096 of the RCMV genomic sequence ${ }^{42}$. As a result of this insertion, the fragment generated by PCR from this control plasmid is $138 \mathrm{bp}$ larger than the PCR fragment that is generated from MCMV genomic DNA (500 bp versus $362 \mathrm{bp}$ ). These fragments can be easily distinguished by agarose gel electrophoresis. The reaction mixture contained $0.2 \mu \mathrm{M}$ of each primer, $10 \mathrm{mM}$ Tris $\mathrm{HCl} \mathrm{pH} 8.5,50 \mathrm{mM} \mathrm{KCl}, 3.5 \mathrm{mM}$ $\mathrm{MgCl}_{2}, 0.2 \mathrm{mM}$ dNTPs, 1.25 units of HotStarTaq DNA polymerase (Qiagen, Leusden, the Netherlands). The PCR was performed by an initial incubation at $95^{\circ} \mathrm{C}$ for $15 \mathrm{~min}$ to activate the HotStarTaq enzyme with a subsequent 40 amplification cycles consisting of denaturation at $95^{\circ} \mathrm{C}$ for $30 \mathrm{~s}$, annealing at $58^{\circ} \mathrm{C}$ for $1 \mathrm{~min}$, and extension at $72^{\circ} \mathrm{C}$ for $1 \mathrm{~min}$. After the final cycle the extension step was prolonged by $5 \mathrm{~min}$ at $72^{\circ} \mathrm{C}$ and subsequently the temperature was lowered to $15^{\circ} \mathrm{C}$. Amplification products were separated on a $1.5 \%$ ethidium bromide-stained agarose gel. The sensitivity of the PCR technique was verified in each run by amplification of various serial dilutions of the p189-p155 plasmid (100, 10 and 1 copies).

\section{DNA real-time PCR technique}

All DNA samples testing positive for the standard MCMV PCR were used to perform real-time PCR (ABI Prism 7000) to observe differences in MCMV genome copy numbers in the different mice strains. Assays were prepared in 96 well Optical Reaction plates (Applied Biosystems, Foster City, California) in a total volume of $25 \mu \mathrm{l}$ containing the following components: $12.5 \mu \mathrm{l}$ of TaqMan universal master mix ( $2 x$ concentrated, Applied Biosystems), $300 \mathrm{nM}$ of forward primer, $300 \mathrm{nM}$ reverse primers, $200 \mathrm{nM}$ probe and $1 \mu \mathrm{g}$ DNA sample. Furthermore, when PCR inhibition was observed in the standard MCMV PCR technique, DNA samples were 10-fold diluted prior to application in the real-time PCR. Primers and probes for the detection of MCMV were based on the MCMV glycoprotein B sequence (gB, GenBank accession number M735191, forward primer 5'-AGGGCTTGGAGAGGACCTACA-3', reverse primer 5'-GCCCGTCGG CAGTCTAGTC-3' and probe 5'-AGCTAGACGACAGCCAACGCAACGA-3'). The probe carried a 5' FAM reporter and a 3' TAMRA quencher group. Thermal cycling started with UNG activation for 2 min at $50^{\circ} \mathrm{C}$, followed by HotStarTaq activation during $10 \mathrm{~min}$ at $95^{\circ} \mathrm{C}$. Thereafter 42 cycles of amplification were run consisting of $15 \mathrm{~s}$ at $95^{\circ} \mathrm{C}$ and $1 \mathrm{~min}$ at $60^{\circ} \mathrm{C}$. A negative control, containing reagents only, and serial dilutions of plasmid containing the MCMV gB sequence from position 930 to position 1348 were included in each run to generate a standard curve. The concentrations of the plasmid dilutions were: $10^{5}, 10^{4}, 10^{3}, 10^{2}, 10$ and 1 copy. The MCMV gB DNA concentration in the unknown samples was calculated by the ABI Prism 7000 SDS Software using the data from the standard curve. Each sample was measured twice and the average concentration was used.

\section{Plaque assay of MCMV}

The presence of infectious virus in salivary gland, lung, liver and spleen was determined by titrating organ homogenates using a slightly modified plaque 
assay as previously described by Bruggeman et al. ${ }^{8}$ These modifications were restricted to in triple infection of confluent Mouse Embryo Fibroblast (MEF) layers. Plaque assays were performed at 2, 4 and 6 days p.i. for lung, liver and spleen and at 6,14 and 28 days p.i. for the salivary gland. Values given are calculated for $100 \mathrm{mg}$ of organ. The lower detection limit of the plaque assay was calculated to be $16.7 \mathrm{PFU} / \mathrm{ml}$ by in triple measurements.

\section{Statistical analysis of data}

Significant differences in MCMV DNA copies and number of PFUs between both mouse strains were determined using the nonparametric Mann-Whitney $U$ test for independent samples. Data are expressed as mean \pm S.E.M. To determine the correlation between plaque assay and real-time PCR technique and to determine their relative sensitivity, all real-time PCR data (copies DNA/1 $\mu \mathrm{g}$ total DNA) were recalculated to PFUs per $100 \mathrm{mg}$ organ. To this end, we first had to determine the DNA yield per $100 \mathrm{mg}$ of each specific organ $(520 \pm 154$ $\mu \mathrm{g}$ DNA $100 \mathrm{mg}$ Salivary gland, $485 \pm 64 \mu \mathrm{g}$ DNA/100 mg spleen, $449 \pm 129 \mu \mathrm{g}$ DNA $100 \mathrm{mg}$ liver and $145 \pm 49 \mu \mathrm{g}$ DNA $/ 100 \mathrm{mg}$ lung). As we used only $1 \mu \mathrm{g}$ total DNA from each tissue homogenate in the real-time PCR, it was assumed that the number of MCMV copies/100 mg tissue equaled the number of copies measured in the real-time PCR assay times the amount of total DNA/100 mg tissue. The number of PFUs/100mg tissue was determined by dividing the calculated number of MCMV copies $/ 100 \mathrm{mg}$ tissue by 500 , assuming that the molecular equivalent of one PFU is $\sim 500$ viral genomes ${ }^{26}$. After recalculating DNA copies to PFU values, the correlation between the two techniques was determined by linear regression on data positive with both techniques. In all cases, $P<0.05$ was considered statistically significant.

\section{RESULTS}

\section{Organ specific differences in viral load between BALB/C and C57BL/6J mice determined by the real-time PCR technique}

In fig. 1 real-time PCR data are shown for all organs studied. MCMV DNA copy number in BALB/c mice is highest in the spleen at 4 days p.i. $\left(5.1 \times 10^{5}\right.$ copies DNA/ $\mu$ g total DNA), followed by the liver at 4 days p.i. $\left(2.9 \times 10^{5}\right.$ copies $\mathrm{DNA} / \mu \mathrm{g}$ total DNA) and salivary gland at 14 days p.i. $\left(2.6 \times 10^{5}\right.$ copies DNA/ $\mu \mathrm{g}$ total DNA). In the C57BL/6J mice the liver (at 4 days p.i.) showed the highest

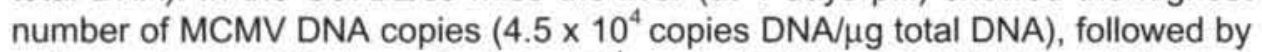
salivary gland at 28 days p.i. $\left(2.1 \times 10^{4}\right.$ copies DNA/ $\mu$ g total DNA $)$ and blood at 2 days p.i. ( $10^{4}$ copies DNA/ $\mu$ g total DNA). In addition, despite a similar timedependent viral dissemination pattern seen in various organs from both mice strains, MCMV-sensitive BALB/c mice generally showed a significantly higher MCMV DNA copy number in all organs examined than MCMV-resistant C57BL/6J mice. Highest inter-strain differences were seen in the salivary gland at 14 days p.i.; in the spleen at 4 days p.i.; in the liver at 4 days p.i. and in the lung at 6 days p.i. Furthermore, although the heart had been sectioned in 3 compartments to determine the possible influence of blood pressure on viral 
infection, no significant differences in MCMV copy number were observed between the different compartments in both mouse strains.

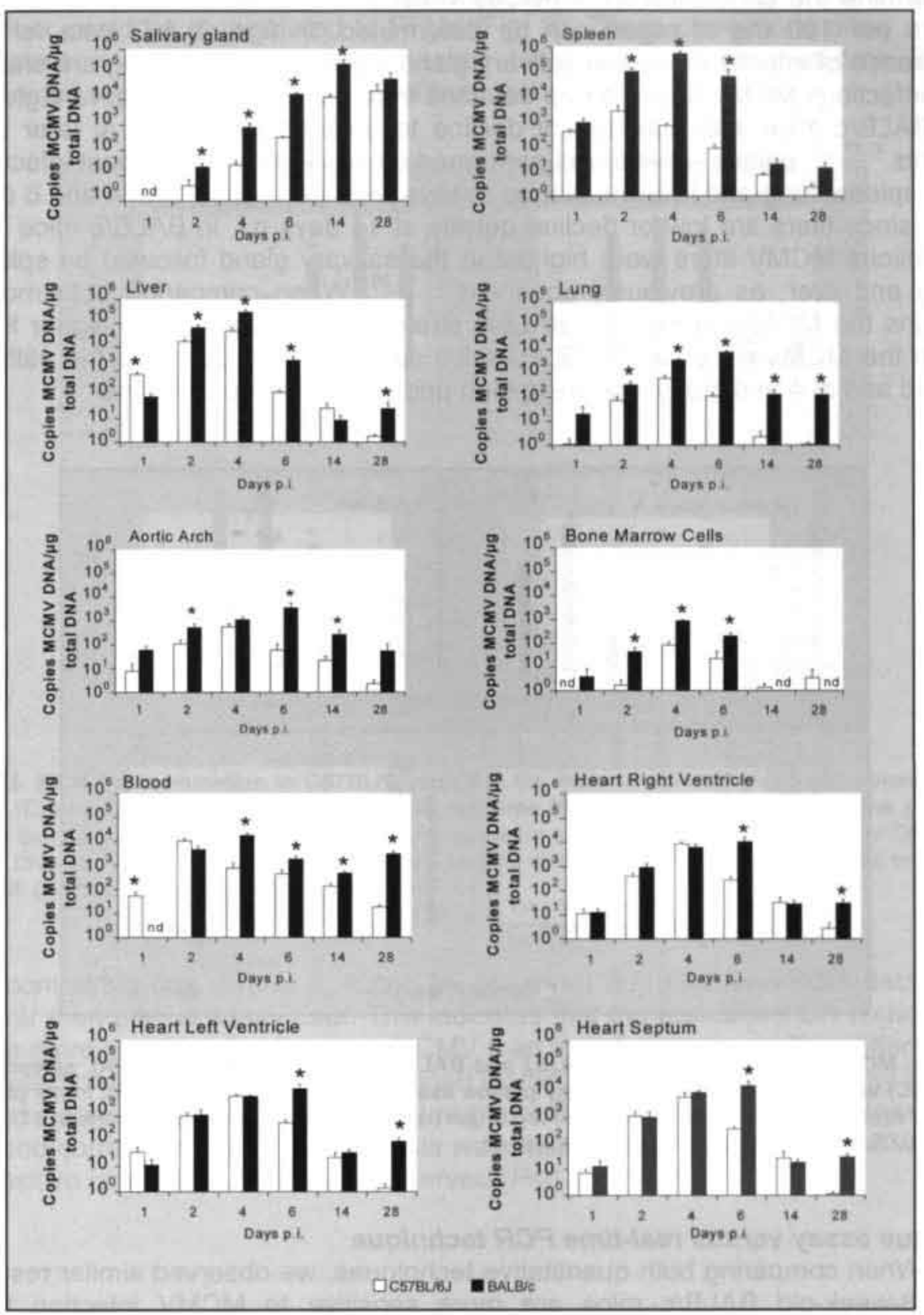

Fig. 1. MCMV dissemination in C57BL/6J and BALB/C mice in salivary gland, spleen, liver, lung, aortic arch, bone marrow, blood, heart right ventricle, heart left ventricle and heart septum as determined by the real-time MCMV PCR technique ( $n=4$ at each time point). Data are expressed mean \pm S.E.M. (*) Statistically significant difference between strains at these specific time points $(P<0.05)$; nd: not detected. 
Organ specific differences in viral load between BALB/C and C57BL/6J mice determined by plaque assay

Since mid-20th century the plaque assay is the standard technique used to determine the concentration of herpes viruses ${ }^{13,43}$. With this technique, virus titers per $100 \mathrm{mg}$ of organ can be determined. In figs. 2 A-D data for the presence of infectious virus in salivary gland, spleen, liver and lung are shown. As infectious MCMV titers can be detected from day $7 \mathrm{p}$.i. in the salivary glands of BALB/c mice with subsequent decline to undetectable levels at later time points ${ }^{4,27,28}$, plaque assays was performed on 6,14 and 28 days post infection. For spleen, lung and liver the plaque assays were performed at 2, 4 and 6 days p.i., since titers are low or decline quickly at 14 days p.i. in BALB/c mice ${ }^{4.28}$. Infectious MCMV titers were highest in the salivary gland followed by spleen, lung and liver, as previously observed ${ }^{2,4}, 28$. When comparing both mouse strains the MCMV-susceptible BALB/c strain showed significantly higher titers than the MCMV-resistant C57BL/6J mice strain at 14 days p.i. in the salivary gland and at 4 and 6 days for the spleen and 6 days for lung and liver.

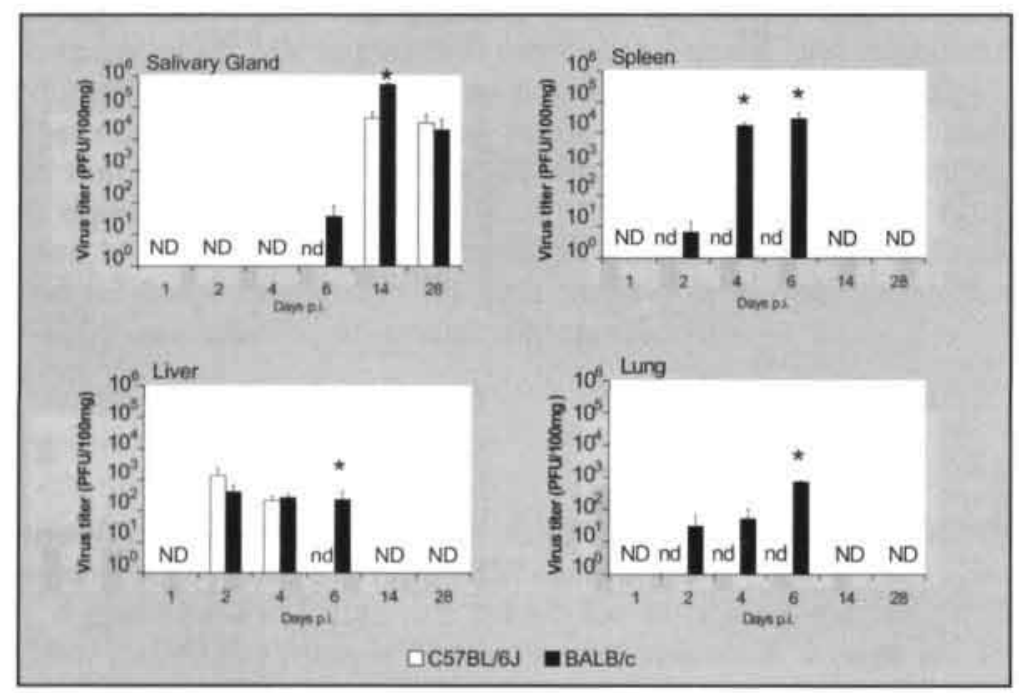

Fig. 2. MCMV dissemination in C57BL/6J and BALB/C mice in salivary gland (A), spleen (B), liver (C) and lung (D) as determined by plaque assay $(n=4$ at each time point). In the plaque assay virus titers were determined in $100 \mathrm{mg}$ organ tissue. Data were expressed as mean \pm S.E.M. (") $P<0.05$; nd: not detected; ND: not determined.

\section{Plaque assay versus real-time PCR technique}

When comparing both quantitative techniques, we observed similar results; i.e. 8-week-old BALB/c mice are more sensitive to MCMV infection than C57BL/6J mice. However, before determining the correlation between both techniques with respect to sensitivity, input values should be comparable in both assays. Since $100 \mathrm{mg}$ of lung, liver, salivary gland or spleen tissue - used in the plaque assay - may not contain similar amounts of total DNA, differences between both techniques may result from differences in input material. 
Therefore, we determined the amount of total DNA in $100 \mathrm{mg}$ of each of these tissues. Then MCMV DNA copy numbers, obtained in the real-time PCR, were recalculated to $100 \mathrm{mg}$ organ tissue. Furthermore, by means of the genome-toPCR ratio of approximately 500 , as determined by Kurz et al. ${ }^{26}$. DNA copy number could be recalculated to PFUs (Fig. 3 ). These corrections allow a fair comparison between the plaque assay technique and the real-time PCR technique regarding the sensitivity of both techniques.

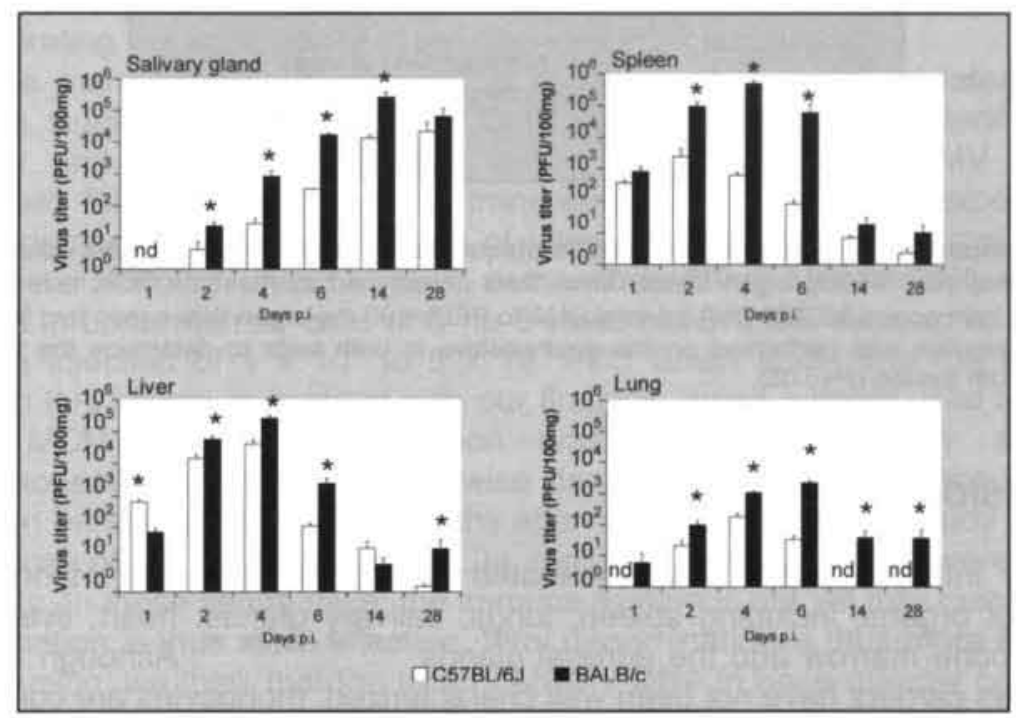

Fig. 3. MCMV dissemination in C57BL/6J and BALB/C mice in salivary gland (A), spleen (B), liver (C) and lung (D) as determined by the real-time MCMV PCR ( $n=4$ at each time point). Virus titers determined by real-time PCR technique were recalculated from copies MCMV DNA/ $\mu \mathrm{g}$ total DNA to PFUs/100 mg organ tissue (see text for details). Data were expressed as mean \pm S.E.M. (*) $P<0.05$; nd: not detected.

By comparing figs. 2 and 3 , it can be observed that real-time PCR data are higher than plaque assay data. This indicates that the real-time PCR technique is far more sensitive for detecting MCMV than the plaque assay. This difference in detection sensitivity may be explained by the fact that the plaque assay is not able to detect latent virus in contrast to the real-time PCR technique. However, a good correlation between both tests was observed on these occasions where a positive plaque test result was observed $(P<0.05$, Fig. 4$)$. 


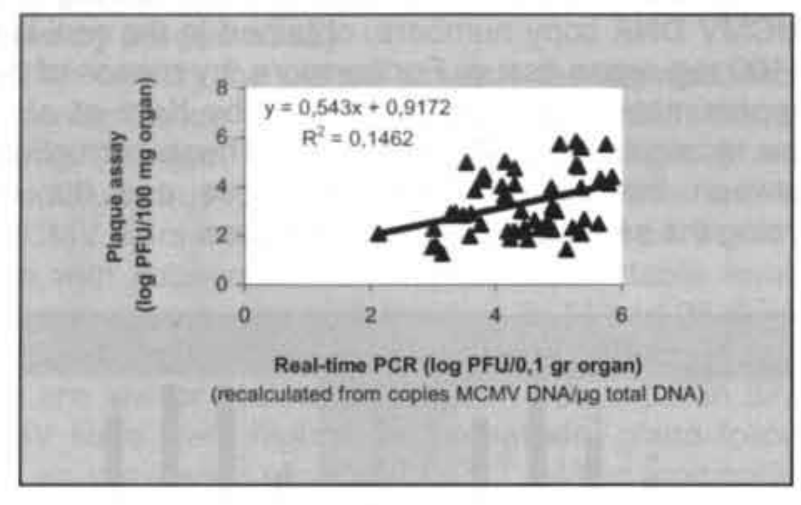

Fig. 4. Comparison of real-time PCR versus plaque assay data. Virus titers were determined by plaque assay per $100 \mathrm{mg}$ organ tissue. Virus titers determined by real-time PCR technique were converted from copies MCMV DNA/ $\mu$ g total DNA to PFUs/100 mg organ tissue (see text for details). Linear regression was performed on the data positive in both tests to determine the correlation between both assays $(P<0.05)$.

\section{$>$ DISCUSSION}

After infection, CMV is disseminated in a time-dependent manner to a variety of organs, including spleen, lungs, salivary glands, heart, liver, brain, kidney, bone marrow and the adrenal glands ${ }^{3,5,11,12,24,32}$. Although the cells serving as carriers have not been well characterized, monocytes are considered the main candidates responsible for dissemination of the CMV genome to distinct organs ${ }^{22,33,41}$. Following the primary infectious phase, the virus remains present in a latent phase, which is characteristic for all herpes viruses. Unfortunately, detection and sensitive quantification of CMV present at this stage is not possible by the use of the golden standard, the plaque assay, since only infectious virus can be quantified by this technique. To avoid this, techniques based on nucleic acid amplification (PCR) can be used. However, because of the multiple handlings per sample, previously described (semi-) quantitative PCR techniques are sensitive to carry-over contamination and are relatively time-consuming ${ }^{17.44}$. These problems can be avoided by the use of the real-time PCR technique ${ }^{9.14}$. By using a dual-labeled fluorogenic probe, the process of amplification can be monitored in a closed tube in real-time ${ }^{20 .}{ }^{21}$. End-point manipulations are not necessary for product quantification thereby reducing contamination risk. Furthermore, both aforementioned (semi-) quantitative PCR techniques are quite laborious compared to the real-time PCR technique, in particular when a whole range of organs needs to be screened for MCMV copy numbers. For example, while in 1 real-time PCR run 41 samples (in duplo) together with two negative and six standard samples (in duplo) can be quantified at the same time, 96 tubes are needed in the technique of Grzimek et al. to determine only five samples with the appropriate controls. Therefore, viral dissemination and presence were studied in this manuscript with a MCMV realtime PCR technique developed in house. To validate the applicability of this technique, we included both $\mathrm{C} 57 \mathrm{BL} / 6 \mathrm{~J}$ and BALB/c. Both inbred strains, 
although different in cytomegalovirus susceptibility (low in C57BL/6J, high in $B A L B / c)$, are the most prominent mouse strains used in MCMV infection studies. As the latter one is primarily used to study virus replication, latency and reactivation ${ }^{3,4,23,25-27,31,45}$, the former one is the primary background strain for various genetically modified mice used in studying the host response to viral infection and pathogenesis ${ }^{30,34,36-38}$. We used both BALB/C and C57BL/6J as major differences in viral dissemination may be anticipated between both strains. As expected, we found higher MCMV DNA copy numbers in the majority of organs derived from BALB/c mice at almost every time point, demonstrating the applicability of the real-time PCR technique.

Bone marrow cells are thought to be important sources of latent CMV. Previous studies demonstrated that CMV can be present in a latent form in dendritic and monocyte precursor cells ${ }^{18}$ and that latent $\mathrm{CMV}$ can be reactivated following bone marrow transplantation ${ }^{29}$. However, experimental studies demonstrating the presence of latent MCMV in bone marrow cells of BALB/C are limited. Yuhasz et al. ${ }^{46}$ demonstrated that MCMV DNA could be detected in bone marrow cells of 6 - to 8 -week-old BALB/c mice up to 20 days following injection of $1 \times 10^{4}$ to $5 \times 10^{4} \mathrm{PFU}$ Smith strain into the tail vein. Although this seems in contrast with our findings, these authors used a 10 -fold higher MCMV dose and infection was done intravenously and not intraperitoneally. Another study likewise demonstrated the presence of latent MCMV in bone marrow cells 6 months after infection, but in this study an even higher dose of $10^{5} \mathrm{PFU}$ was used ${ }^{25}$. In addition, 3-week-old mice were used in this study. In these young mice, the immune system is not yet fully matured and dissemination is thus more effective. Viral dissemination is thus more effective. In conclusion, we think that the lack of MCMV DNA in bone marrow cells at 14 and 28 days post infection in our study is merely by an effect of differences in study design and virus dose and is not the result of real-time PCR detection errors.

As previously shown by the plaque assay ${ }^{1,39,40}$ and as expected, BALB/c mice showed higher MCMV DNA copy numbers than C57BL/6J mice. Highest inter-strain differences were seen in the salivary gland at 14 days p.i., in the lung at 6 days p.i. and in the spleen and liver at 4 days p.i. This is in accordance with a previous article demonstrating the highest inter-strain differences in the spleen at 4 days post infection ${ }^{39}$. When comparing the real-time PCR technique with the plaque assay, we demonstrated a correlation between the two techniques implicating that our technique is equally suitable in detecting MCMV infection. Nonetheless, when looking at the relative sensitivity of both techniques, the real-time PCR technique showed higher levels of viral titers than the plaque assay. Therefore, for determining viral presence, the former technique seems the best choice. Nevertheless, one has to keep in mind that this increased sensitivity of the real-time PCR technique is only the case when determining viral presence. When interested in the quantification of infectious virus the plaque assay has to be used.

Although the real-time PCR technique does not allow any discrimination between active, replicating virus and latent virus, we have demonstrate that this technique is more sensitive than the plaque assay for quantifying the total number of cytomegalovirus particles in different organs. Since latent CMV infections have been shown to be important in various pathologies and possibly 
in the development of atherosclerosis this real-time PCR technique could prove to be extremely useful for studying the effects of new drugs (i.e. dose-response relations) aimed at total virus eradication.

\section{ACKNOWLEDGEMENTS}

The authors would like to thank $P$. Terporten for statistical assistance and $\mathrm{S}$. Stevens for assistance with the animal experiments.

\section{REFERENCES}

1. Allan JE, Shellam GR. Genetic control of murine cytomegalovirus infection: virus titres in resistant and susceptible strains of mice. Arch Virol. 1984;81:139-150.

2. Andrews DM, Farrell HE, Densley EH, Scalzo AA, Shellam GR, Degli-Esposti MA. NK1.1+ cells and murine cytomegalovirus infection: what happens in situ? J Immunol. 2001:166:17961802.

3. Balthesen M, Messerle M, Reddehase MJ. Lungs are a major organ site of cytomegalovirus latency and recurrence, $J$ Virol. 1993;67:5360-5366.

4. Balthesen M. Dreher L, Lucin P. Reddehase MJ. The establishment of cytomegalovirus latency in organs is not linked to local virus production during primary infection. $J$ Gen Virol. 1994:75:2329-2336.

5. Blok MJ, Savelkouls KGM, Grauls GELM, Bruggeman CA, Vink C. Immediate early-1 mRNA expression and virus production are restricted during the acute phase of rat cytomegalovirus infection in immunocompetent rats. In: Blok MJ, ed. Monitoring the course of CMV infection by detection of specific viral transcripts: Thesis University Maastricht; 2001: 91-124 (ISBN 909015374-8).

6. Boom R, Sol CJ, Salimans MM, Jansen CL, Wertheim-van Dillen PM, van der Noordaa J. Rapid and simple method for purification of nucleic acids. J Clin Microbiol. 1990;28:495-503.

7. Britt WJ, Alford CA. Cytomegalovirus. In: Fields BN, Knipe DM, Howley PM, eds. Fields Virology. Philadelphia: Lippencott-Raven Publishers; 1996: 2493-2523.

8. Bruggeman CA, Meijer H, Dormans PH, Debie WM, Grauls GE, van Boven CP. Isolation of a cytomegalovirus-like agent from wild rats. Arch Virol. 1982;73:231-241.

9. Bustin SA. Absolute quantification of mRNA using real-time reverse transcription polymerase chain reaction assays. J Mol Endocrinol. 2000;25:169-193.

10. Chalmer JE, Mackenzie JS, Stanley NF. Resistance to murine cytomegalovirus linked to the major histocompatibility complex of the mouse. J Gen Virol. 1977;37:107-114.

11. Collins T, Pomeroy C, Jordan MC. Detection of latent cytomegalovirus DNA in diverse organs of mice. J Infect Dis. 1993;168:725-729.

12. Dilloo D. Josting $A$, Burdach $S$. CMV infection modulates interleukin-6 production in human bone marrow stroma cells. Bone Marrow Transplant. 1991;7:152.

13. Field AK, Fong J. Mouse salivary gland virus plaque assay on a stable line of mouse embryo cells. J Bacteriol. 1964;87:1238-1239.

14. Gerard CJ, Olsson K, Ramanathan R, Reading C, Hanania EG. Improved quantitation of minimal residual disease in multiple myeloma using real-time polymerase chain reaction and plasmid-DNA complementarity determining region III standards. Cancer Res. 1998;58:39573964.

15. Gibson UE, Heid CA, Williams PM. A novel method for real time quantitative RT-PCR. Genome Res, 1996;6:995-1001.

16. Grundy JE, Mackenzie JS, Stanley NF. Influence of $\mathrm{H}-2$ and non- $\mathrm{H}-2$ genes on resistance to murine cytomegalovirus infection. Infect Immun. 1981;32:277-286.

17. Grzimek NK, Dreis D. Schmalz S, Reddehase MJ. Random, asynchronous, and asymmetric transcriptional activity of enhancer-flanking major immediate-early genes ie $1 / 3$ and ie2 during murine cytomegalovirus latency in the lungs. $J$ Virol. 2001:75:2692-2705.

18. Hahn G, Jores R, Mocarski ES. Cytomegalovirus remains latent in a common precursor of dendritic and myeloid cells. Proc Natl Acad Sci USA. 1998;95:3937-3942. 
19. Heid CA, Stevens J, Livak KJ, Williams PM. Real time quantitative PCR. Genome Res. 1996;6:986-994.

20. Higuchi R, Dollinger G, Walsh PS, Griffith R. Simultaneous amplification and detection of specific DNA sequences. Biotechnology (NY). 1992;10:413-417.

21. Higuchi R, Fockler C, Dollinger G, Watson R. Kinetic PCR analysis: real-time monitoring of DNA amplification reactions. Biotechnology (NY). 1993;11:1026-1030.

22. Ibanez CE, Schrier R, Ghazal P, Wiley C, Nelson JA. Human cytomegalovirus productively infects primary differentiated macrophages. J Virol. 1991;65:6581-6588.

23. Kercher L, Mitchell BM. Persisting murine cytomegalovirus can reactivate and has unique transcriptional activity in ocular tissue. J Virol. 2002:76:9165-9175.

24. Klotman ME, Henry SC, Greene RC, Brazy PC, Klotman PE, Hamilton JD. Detection of mouse cytomegalovirus nucleic acid in latently infected mice by in vitro enzymatic amplification. $J$ Infect Dis. 1990;161:220-225.

25. Koffron AJ, Hummel M, Patterson BK, Yan S, Kaufman DB, Fryer JP, Stuart FP, Abecassis MI. Cellular localization of latent murine cytomegalovirus. J Virol. 1998:72:95-103.

26. Kurz S, Steffens HP, Mayer A, Harris JR, Reddehase MJ. Latency versus persistence or intermittent recurrences: evidence for a latent state of murine cytomegalovirus in the lungs. $J$ Virol. 1997:71:2980-2987.

27. Manning WC, Stoddart CA, Lagenaur LA, Abenes GB, Mocarski ES. Cytomegalovirus determinant of replication in salivary glands. $J$ Virol. 1992;66:3794-3802.

28. Matsuzawa H, Shimizu K, Okada K, Ando K, Hashimoto K, Koga Y. Analysis of target organs for the latency of murine cytomegalovirus DNA using specific pathogen free and germfree mice. Arch Virol. 1995;140:853-864.

29. Meyers JD, Flournoy N, Thomas ED. Risk factors for cytomegalovirus infection after human marrow transplantation. J Infect Dis. 1986;153:478-488.

30. Polic B, Jonjic S, Pavic I, Crnkovic I, Zorica I, Hengel H, Lucin P, Koszinowski UH. Lack of MHC class I complex expression has no effect on spread and control of cytomegalovirus infection in vivo. J Gen Virol. 1996;77:217-225.

31. Pomeroy C, Delong D, Clabots C, Riciputi P. Filice GA. Role of interferon-gamma in murine cytomegalovirus infection. J Lab Clin Med. 1998;132:124-133.

32. Reddehase MJ, Balthesen M, Rapp M, Jonjic S, Pavic I, Koszinowski UH. The conditions of primary infection define the load of latent viral genome in organs and the risk of recurrent cytomegalovirus disease. J Exp Med. 1994;179:185-193.

33. Rice GP, Schrier RD, Oldstone MB. Cytomegalovirus infects human lymphocytes and monocytes: virus expression is restricted to immediate-early gene products. Proc Natl Acad Sci USA. 1984;81:6134-6138.

34. Riera L, Gariglio M, Valente G, Mullbacher A, Museteanu C, Landolfo S, Simon MM. Murine cytomegalovirus replication in salivary glands is controlled by both perforin and granzymes during acute infection. Eur $J$ Immunol. 2000;30:1350-1355.

35. Roizman B. Herpes simplex viruses and their replication. In: Fields BN, Knipe DM, Howley PM. eds. Fields Virology. Philadelphia: Lippencott-Raven Publishers; 1996 :

36. Salazar-Mather TP, Hamilton TA, Biron CA. A chemokine-to-cytokine-to-chemokine cascade critical in antiviral defense. J Clin Invest. 2000;105:985-993.

37. Salazar-Mather TP. Lewis CA. Biron CA. Type I interferons regulate inflammatory cell trafficking and macrophage inflammatory protein 1alpha delivery to the liver. $J$ Clin Invest. 2002;110:321-330.

38. Salem ML, Hossain MS. In vivo acute depletion of $C D 8(+) T$ cells before murine cytomegalovirus infection upregulated innate antiviral activity of natural killer cells. Int $J$ Immunopharmacol. 2000;22:707-718.

39. Scalzo AA, Fitzgerald NA, Simmons A, La Vista AB, Shellam GR. Cmv-1, a genetic locus that controls murine cytomegalovirus replication in the spleen. J Exp Med. 1990:171:1469-1483.

40. Scalzo AA, Fitzgerald NA, Wallace CR, Gibbons AE, Smart YC, Burton RC, Shellam GR. The effect of the Cmv-1 resistance gene, which is linked to the natural killer cell gene complex, is mediated by natural killer cells. J Immunol. 1992;149:581-589.

41. Taylor Wiedeman J, Sissons JG, Borysiewicz LK, Sinclair JH. Monocytes are a major site of persistence of human cytomegalovirus in peripheral blood mononuclear cells. $J$ Gen Virol. 1991:72:2059-2064.

42. Vink C, Beuken E, Bruggeman CA. Complete DNA sequence of the rat cytomegalovirus genome. J Virol, 2000;74:7656-7665.

43. Wentworth BB, French L. Plaque assay of cytomegalovirus strains of human origin. Proc Soc Exp Biol Med. 1970;135:253-258. 
44. White KL, Slobedman B, Mocarski ES. Human cytomegalovirus latency-associated protein pORF94 is dispensable for productive and latent infection. J Virol. 2000;74:9333-9337.

45. Yu Y, Henry SC, Xu F. Hamilton JD. Expression of a murine cytomegalovirus early-late protein in "latently" infected mice. $J$ Infect Dis. 1995:172:371-379.

46. Yuhasz SA, Dissette VB, Cook ML, Stevens JG. Murine cytomegalovirus is present in both chronic active and latent states in persistently infected mice. Virology. 1994:202:272-280. 




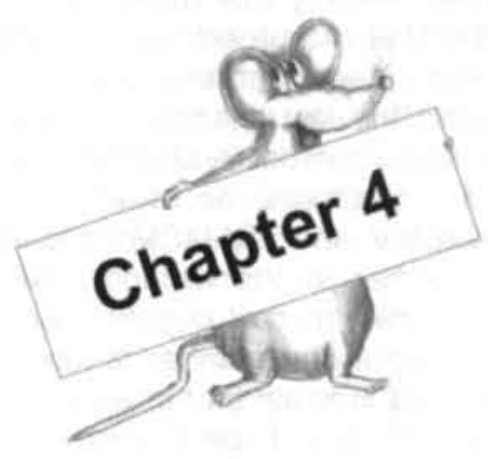

Mouse cytomegalovirus antigens stimulate $\mathcal{T}$ cell influx in atherosclerotic lesions thereby aggravating atherosclerosis in apoE-- mice

INGE VLIEGEN, SELMA HERNGREEN, GERT GRAULS, CATHRIEN BRUGGEMAN, FRANK STASSEN

Departments of Medical Microbiology, Cardiovascular Research Institute Maastricht (CARIM), University of Maastricht, the Netherlands

Submitted 


\section{ABSTRACT}

We have previously demonstrated that mouse cytomegalovirus (MCMV) infection aggravates atherosclerosis by stimulating the ongoing inflammatory process in the vascular wall. Here we investigated whether MCMV antigenic stimulation is sufficient to aggravate atherosclerosis. To this end, apo $\mathrm{E}^{-1}$ mice received a single or seven monthly low dose injections with MCMV or UVinactivated MCMV (UV-MCMV). Atherosclerosis progression, inflammation in atherosclerotic lesions and internal organs and MCMV DNA copies were determined at 2 weeks after the last injection. After a single MCMV infection more MCMV DNA copies were present in all organs than after multiple MCMV infections. After UV-MCMV injection(s) no MCMV DNA could be detected. A single injection of both MCMV and UV-MCMV significantly increased mean lesion area and T cell number in the lesions, while only MCMV infection increased T cell numbers in the internal organs. Furthermore, MCMV but not UV-MCMV significantly increased the number of lateral xanthomas following 7 monthly injections. These data indicate that in apoE $\mathrm{E}^{-1}$ mice (i) low dose MCMV injections are sufficient for MCMV dissemination, (ii) a single injection with MCMV antigens is sufficient to accelerate the atherosclerotic process, and (iii) only virulent MCMV aggravates the atherosclerotic process after multiple injections. 


\section{INTRODUCTION}

Since the late 1970's, when Fabricant et al. ${ }^{7}$ established that chickens infected with an avian herpes virus develop an atherosclerosis-like disease, evidence linking atherosclerosis to infections has been accumulating. Currently a clear association between a diversity of infections (incl. cytomegalovirus) and the progression of the atherosclerotic process has been demonstrated ${ }^{6}$.

Cytomegalovirus (CMV) is a member of the $\beta$-herpes subfamily of the herpes virus group. In the immuno-competent host primary infection causes a lifelong asymptomatic latent infection with intermittent shedding of the virus. On the other hand, immuno-compromised patients infected with CMV are at risk of developing severe to lethal diseases like retinitis, colitis and hepatitis depending on the extent of immunosuppression. Several epidemiological reports indicate that chronic CMV infection in humans may play an important role in the pathogenesis of vascular diseases such as atherosclerosis or restenosis ${ }^{4}$. Furthermore, the presence of the virus in atherosclerotic lesions indicates that $\mathrm{CMV}$ is a possible primary etiologic factor or a co-factor in the atherosclerotic process ${ }^{11,21}$.

To study the contribution of CMV to the atherosclerotic process, wellcontrolled in vivo experiments in animals are a necessity. Since atherosclerotic lesions in apoE $\mathrm{E}^{-\alpha}$ mice display a high similarity with human atherosclerotic lesions with respect to distribution and cellular composition ${ }^{22,24}$, this particular mouse model is particularly suitable for studying genetic and environmental influences on the atherosclerotic process. Previously, it has been demonstrated that infections with a single high dose of mouse CMV (MCMV) aggravate the atherosclerotic lesion progression in apoE $\mathrm{E}^{-1}$ mice following an initial rise in circulating IFN $\gamma$ levels ${ }^{2,13}$. This suggests that MCMV stimulates $\mathrm{T}$ cell activation with the production of various $T$ cell associated pro-atherogenic cytokines (eg. IFN $\gamma$, IL-2 or TNF $\alpha$ ), thereby accelerating atherosclerotic plaque development. As replication deficient virus has also been shown to be able to stimulate the production of cytokines ${ }^{3.16}$, we hypothesized that non-virulent MCMV may exert a similar effect on the atherosclerotic process as viable MCMV. Therefore, in this study we evaluated the effect of UV-inactivated MCMV (UV-MCMV) injection on the atherosclerotic process in apoE $\mathrm{E}^{-/}$mice and compared it with the effect induced by infectious virus. Furthermore, several lines of evidence suggest that multiple infections with the same or different infectious pathogens may further aggravate the atherosclerotic process thereby increasing the risk of coronary and peripheral artery disease ${ }^{6,34}$. This motivated us to investigate whether multiple MCMV infections further aggravate the atherosclerotic outcome when compared to a single infection.

\section{MATERIALS AND METHODS}

\section{Mice}

Eight-week-old male specific pathogen-free apoE $\mathrm{E}^{-}$mice were obtained from Charles River, Someren, the Netherlands. All mice were housed under standardized conditions, fed with commercially available chow diet (SRM-A, Hope Farms) and had free access to tap water. 


\section{Virus and infection of mice}

The Smith strain of MCMV (kindly provided by Dr. J. Neyts, Rega Institute, University of Leuven, Belgium) was used during the experiments. Salivary gland-passaged MCMV was prepared by homogenization of salivary glands of BALB/c mice, which were infected with $2 \times 10^{4} \mathrm{PFU}$ of MCMV 4 weeks previously.

UV-inactivated MCMV (UV-MCMV) was obtained by $2 \mathrm{~h}$ exposure of salivary gland extracted MCMV to a UV-lamp $\left(2.6 \mathrm{~mW} / \mathrm{cm}^{2}\right)$ at a distance of 3 $\mathrm{cm}$ under permanent shaking. When this preparation was examined for viable MCMV in mouse embryonic fibroblast (MEF) cell cultures, none was detected.

Before injecting either MCMV or UV-MCMV into apoE mice, original pools were diluted $2 \times 10^{5}$ times in sterile phosphate buffered saline to reach a final concentration of $10^{2} \mathrm{PFU} / 200 \mu \mathrm{l}$. This also eliminated potential confounding effects of pure salivary gland homogenates.

Forty-eight apoE mice were randomly divided into 6 groups. At 8 weeks of age, 32 mice were inoculated by intraperitoneal injection with either $10^{2}$ PFU of MCMV $(n=16)$ or an equal dose of UV-MCMV $(n=16)$ in a volume of $200 \mu \mathrm{l}$ of sterile phosphate buffered saline (PBS). The remaining mice were not injected and used as controls. At 2 weeks post infection half of the MCMV and UVMCMV injected mice as well as half of the control mice were sacrificed. The remaining MCMV and UV-MCMV injected mice received 6 additional monthly injections with equal doses of MCMV or UV-MCMV. All mice were sacrificed 2 weeks after the last injection at an age of 34 weeks. A control group $(n=8)$ was sacrificed at a similar age. A low sub-clinical dose of MCMV $\left(10^{2}\right.$ PFU) was chosen (i) to prevent preliminary death in the multiple infection group and (ii) to mimic the human situation where chronic latent CMV infection with recurrent intervals of low virus shedding takes place e.g. during periods of stress ${ }^{9.27}$.

\section{Tissue collection}

Tissue collection was done as previously described ${ }^{30}$. The middle longitudinally cut paraffin section of the aortic arch was collected, hematoxylineosin stained and mean lesion area and number were determined. During analysis, multiple lateral xanthomas flanking the fibrofatty nodules (as recently described by Rosenfeld et al. ${ }^{26}$ ) were observed in mice at an age of 34 weeks. The number of these lateral xanthomas was scored and compared between groups. Several internal organs (lung, liver, spleen and salivary gland) were isolated and either fixed in 3.7\% PBS-buffered formaldehyde for histological examination or snap frozen for determination of MCMV DNA. Also, the remainder of the aortic tree was collected for MCMV DNA detection.

\section{Inflammatory response}

T lymphocyte number, as marker of the inflammatory response, was evaluated in paraffin imbedded sections of the lung, liver, salivary gland and aortic arch. From the aortic arch, the longitudinally cut paraffin section following the above-described hematoxylin-eosin stained paraffin section was stained for T cells. T lymphocyte numbers were not evaluated in paraffin imbedded crosssections of the spleen because T cell number was very high in all groups and it was impossible to observe an effect of MCMV or UV-MCMV injection. T 
lymphocytes in the paraffin embedded sections from all other tissues were immuno-labeled with a CD3 antibody (rabbit anti-human CD3, DAKO, Glostrup, Denmark) after pre-incubation with pepsin $(0.1 \mathrm{mg} / \mathrm{ml}$ in $0.1 \mathrm{~N} \mathrm{HCl})$ for $30 \mathrm{~min}$. The number of $T$ lymphocytes in the aortic arch was counted and expressed as the number of $T$ lymphocytes per $\mu \mathrm{m}^{2}$. The number of CD3-positive cells in the liver, lung and salivary gland were determined in 5 microscopic fields at a magnification of $400 x$. Thereafter mean values were calculated for each mouse and compared between groups.

\section{Detection of MCMV DNA by PCR}

\section{Standard MCMV PCR.}

DNA was isolated from lung, liver, salivary gland, spleen and the remaining aorta using the Wizard genomic DNA purification kit (Promega) according to the manufacturer's instructions. MCMV-specific PCR was performed as described previously, with minor modifications to increase sensitivity ${ }^{30}$. Briefly, one $\mu \mathrm{g}$ of the isolated DNA was subjected to PCR in a total volume of $50 \mu \mathrm{l}$. To check for the presence of PCR inhibitors, each sample was spiked with 10 copies of plasmid p189-p155. This plasmid contains nucleotides 180,551 to 180,913 of the MCMV Smith genome (Immediate early-1 (IE-1) exon 4, GenBank accession number U68299), which includes the primer sequences, and an additional fragment of $138 \mathrm{bp}$ cloned into the MCMV sequence, corresponding to position 215,968 to 216,096 of the RCMV genomic sequence ${ }^{29}$. As a result of this insertion, the fragment generated by PCR from this control plasmid is $138 \mathrm{bp}$ larger than the PCR fragment that is generated from MCMV genomic DNA (500 bp versus 362 bp). These fragments can be easily distinguished by agarose gel electrophoresis. The reaction mixture contained $0.2 \mu \mathrm{M}$ of each primer, $10 \mathrm{mM}$ Tris $\mathrm{HCl}$ pH $8.5,50 \mathrm{mM} \mathrm{KCl}, 3.5 \mathrm{mM} \mathrm{MgCl}_{2}, 0.2 \mathrm{mM}$ dNTPs, 1.25 units of HotStarTaq DNA polymerase (Qiagen, Leusden, the Netherlands). The PCR was performed by an initial incubation at $95^{\circ} \mathrm{C}$ for $15 \mathrm{~min}$ to activate the HotStarTaq enzyme with 40 subsequent amplification cycles consisting of denaturation at $95^{\circ} \mathrm{C}$ for $30 \mathrm{~s}$, annealing at $58^{\circ} \mathrm{C}$ for $1 \mathrm{~min}$, and extension at $72^{\circ} \mathrm{C}$ for $1 \mathrm{~min}$. After the final cycle, the extension step was prolonged with 5 min at $72^{\circ} \mathrm{C}$ and the temperature was subsequently lowered to $15^{\circ} \mathrm{C}$. Amplification products were separated on a $1.5 \%$ ethidium bromide-stained agarose gel. The sensitivity of the PCR technique was determined to be 1 copy of the p189-p155 plasmid.

\section{Real-time MCMV PCR.}

On all DNA samples, real-time PCR (ABI Prism 7000) was performed to allow us to observe differences in MCMV genome copies in various tissues after single and multiple infections. Assays were prepared in 96 well Optical Reaction plates (Applied Biosystems) in a total volume of $25 \mu$ l containing the following components: $12.5 \mu \mathrm{l}$ of TaqMan universal master mix ( $2 x$ concentrated, Applied Biosystems), $300 \mathrm{nM}$ of forward primer, $300 \mathrm{nM}$ reverse primers, $200 \mathrm{nM}$ probe and $1 \mu \mathrm{g}$ DNA sample. Primers and probes for the detection of MCMV were based on the MCMV glycoprotein B sequence $(\mathrm{gB}$, GenBank accession number M735191, forward primer 5'-AGGGCTTGGAGGGACCTACA-3', reverse primer 5'-GCCCGTCGGCAGTCTAGTC-3' and probe 5'-AGCTAGACGACAGCCAACG 
CAACGA-3'). The probe carried a 5' FAM reporter and a 3' TAMRA quencher group. Thermal cycling started with UNG activation for 2 min at $50^{\circ} \mathrm{C}$, followed by HotStarTaq activation during $10 \mathrm{~min}$ at $95^{\circ} \mathrm{C}$. Then 42 cycles of amplification were run consisting of $15 \mathrm{~s}$ at $95^{\circ} \mathrm{C}$ and 1 minute at $60^{\circ} \mathrm{C}$. A negative control, containing reagents only, and serial dilutions of plasmid containing the MCMV gB sequence from position 930 to position 1348 were included in each run to generate a standard curve. The concentrations of the plasmid dilutions were: $10^{5}, 10^{4}, 10^{3}, 10^{2}, 10$ and 1 copy. The MCMV gB DNA concentration in the unknown samples was calculated by the ABI Prism 7000 SDS Software using the data from the standard curve. Each sample was measured twice and the average concentration was used.

\section{Statistical analysis}

All data are expressed as mean \pm S.E.M. Differences between the 3 groups concerning lesion size and $T$ lymphocyte influx in lesions were analyzed by a non-parametric Kruskall Wallis test. If a $P<0.05$ was obtained, the one-sided Mann-Whitney $U$-test was used to determine the difference between 2 groups. To determine the difference between groups concerning the number of lateral xanthomas a one-way ANOVA was used. T lymphocyte influx in salivary gland and lung after a single infection were analyzed by the one-way ANOVA. T lymphocyte influx in liver after 1 and 7 injections and salivary gland and lung after 7 injections were subjected to a non-parametric Kruskall Wallis test and one-sided Mann-Whitney U-tests. Differences in MCMV DNA numbers between the single and the multiple MCMV-infected groups were analyzed by the MannWhitney $U$-test. A $P<0.05$ was considered as statistically significant.

\section{RESULTS}

\section{Single injection of MCMV or UV-MCMV}

\section{MCMV detection}

Despite the low infectious dose $\left(10^{2}\right.$ PFU), MCMV could be detected in all aortic arches after a single injection using the standard PCR technique. Furthermore $75 \%$ of the lungs and salivary glands, $62.5 \%$ of the livers and $87.5 \%$ of the spleens were positive for MCMV. No MCMV DNA could be detected in the UV-MCMV- or mock-injected groups (Table 1). MCMV DNA copies, determined by real-time PCR, were highest in the salivary gland $(2,782$ $\pm 1,155$ copies MCMV DNA/ $\mu$ g total DNA), while MCMV DNA copies in all other organs analyzed were considerably lower or even absent (e.g. $0.34 \pm 0.11$ and

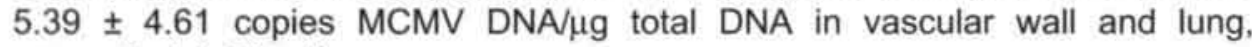
respectively) (Fig. 1). 


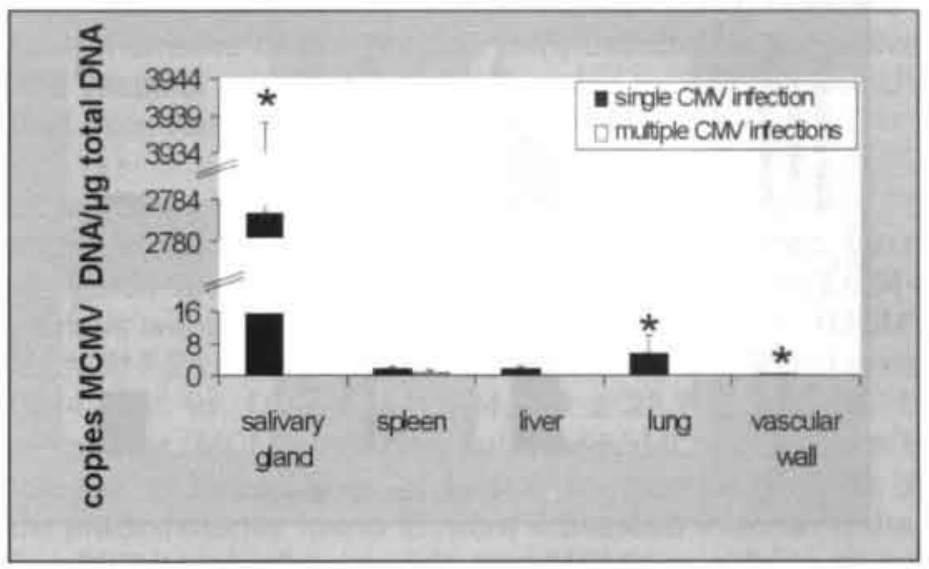

Fig. 1. MCMV DNA numbers determined by the real-time PCR technique after single and multiple MCMV and UV-MCMV injections. Data are expressed as copies MCMV DNA/ $/ \mu$ total DNA. $\mathrm{N}=8$ per group

\section{Atherosclerotic lesions}

Mean lesion area was scored two weeks after a single injection with either MCMV, UV-MCMV or mock. Although the mean number of lesions was not different between groups (MCMV: $2.71 \pm 0.61$ vs. UV-MCMV: $2.22 \pm 0,82$ vs. mock: $2.33 \pm 0.61)$, both MCMV $\left(3,822 \pm 722 \mu \mathrm{m}^{2}\right)$ as well as UV-MCMV $(4,863$ $\pm 1,767 \mu \mathrm{m}^{2}$ ) significantly increased mean lesion area in the aortic arches of infected mice when compared with control mice $\left(1,844 \pm 196 \mu \mathrm{m}^{2}\right)(P<0.05)$. This indicates that a single injection with viable MCMV or MCMV antigens only is sufficient to aggravate the atherosclerotic process.

\section{Inflammatory response}

In the internal organs (liver, lung, salivary gland), a significant increase in T lymphocyte numbers was seen after a single MCMV injection but not after a single UV-MCMV injection (Figs. $2 \mathrm{~B}-\mathrm{D}$ ). This is in line with our observation that MCMV DNA could only be detected in the internal organs following MCMV infection but not after UV-MCMV injection. Moreover, this implicates that the T lymphocyte influx in the internal organs after MCMV infection resembles an acute immune response to viral infections. In atherosclerotic lesions, a single injection with MCMV as well as UV-MCMV increased the mean number of T lymphocytes per $\mu \mathrm{m}^{2}$ to a similar level, which was significantly different from numbers in control mice (Fig. 2 A). The heightened T lymphocyte number in the lesions after both MCMV and UV-MCMV injection indicates that injection with $\mathrm{CMV}$ antigens is sufficient to stimulate the already ongoing immune response in the vascular wall. 


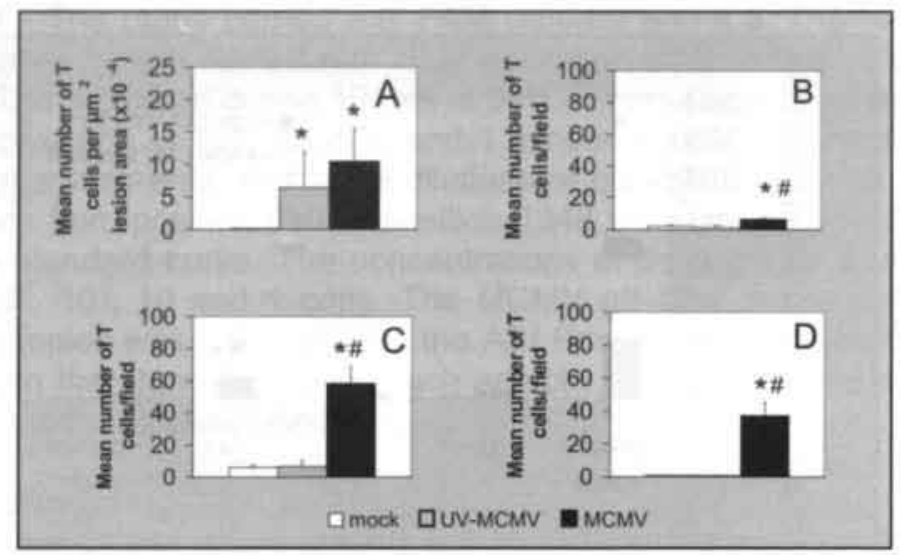

Fig. 2. Effect of a single MCMV or UV-MCMV injection on T lymphocyte numbers in (A) atherosclerotic lesions, (B) liver, (C) lung and (D) salivary gland. T lymphocyte influx was measured after anti-CD3 immunohistochemical staining. Data are expressed as mean number of $T$ cells per $\mu \mathrm{m}^{2}$ lesion area \pm S.E.M. (vascular wall) or mean number of T cells per microscopic field \pm S.E.M. $N=8$ per group. $\left({ }^{*}\right) P<0.05$ when compared with the mock group, (\#) $P<0.05$ when compared with the UV-MCMV group.

\section{Multiple injections}

\section{MCMV detection}

After seven monthly MCMV infections only $25 \%$ of the aortic arches were positive in the standard MCMV PCR, while in the internal organs MCMV DNA could be detected in percentages comparable to percentages found after a single infection (Table 1).

Table 1. Presence of MCMV DNA as determined by the standard PCR technique after single and multiple MCMV and UV-MCMV injections.

\begin{tabular}{|c|c|c|c|c|c|c|}
\hline & \multicolumn{3}{|c|}{ Single injection " } & \multicolumn{3}{|c|}{ Multiple injections " } \\
\hline & mock & $\begin{array}{l}\text { UV- } \\
\text { MCMV }\end{array}$ & MCMV & mock & $\begin{array}{l}\text { UV- } \\
\text { MCMV }\end{array}$ & MCMV \\
\hline Vascular wall & $0 / 8$ & $0 / 8$ & $7 / 8$ & $0 / 8$ & $0 / 8$ & $2 / 8$ \\
\hline Lung & $0 / 8$ & $0 / 8$ & $6 / 8$ & $0 / 8$ & $0 / 8$ & $6 / 8$ \\
\hline Liver & $0 / 8$ & $0 / 8$ & $5 / 8$ & $0 / 8$ & $0 / 8$ & $5 / 8$ \\
\hline Spleen & $0 / 8$ & $0 / 8$ & $7 / 8$ & $0 / 8$ & $0 / 8$ & $6 / 8$ \\
\hline Salivary gland & $0 / 8$ & $0 / 8$ & $6 / 8$ & $0 / 8$ & $0 / 8$ & $4 / 8$ \\
\hline
\end{tabular}

Data are expressed as number of mice positive/group

The number of MCMV DNA copies was very low and varied between $0.02 \pm$ 0.02 copies MCMV DNA/ $\mu$ g DNA (vascular wall) and $0.63 \pm 0.55$ copies MCMV 
DNA/ $\mu$ g DNA (spleen) (Fig. 1). When compared with a single MCMV infection. significantly lower numbers of DNA copies were detected in the salivary gland, the lung and the vascular wall. None of the samples tested from the UV-MCMVor mock-injected mice were positive for MCMV DNA.

\section{Atherosclerotic lesions}

After multiple injections, disease progression was scored by means of lesion number, lesion area and number of lateral xanthomas. In 34-week-old mice no differences were observed concerning lesion number (MCMV: $7.29 \pm$ 0.81 vs. UV-MCMV: $7.25 \pm 0.80$ vs. mock: $9.00 \pm 0.78$ ) and lesion area (MCMV: $175,472 \pm 7,814 \mu \mathrm{m}^{2}$ vs. UV-MCMV: $194,649 \pm 28,706 \mu \mathrm{m}^{2}$ vs. $179,833 \pm$ $\left.34,910 \mu \mathrm{m}^{2}\right)$. However, MCMV-infection but not UV-MCMV injection induced a significant increase in the number of lateral xanthomas (Fig. 3). As lateral xanthomas are predominantly found in more advanced lesions ${ }^{26}$, the increase in number after MCMV infection reveals that MCMV is able to accelerate the formation of complex lesions.

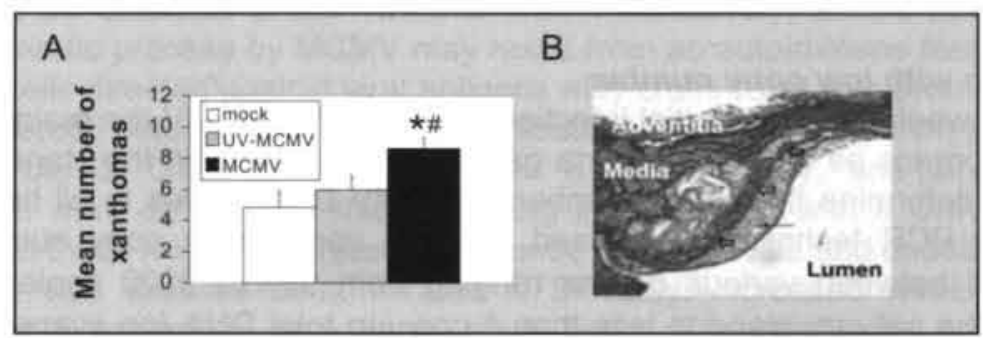

Fig. 3. (A) Effect of seven monthly injections of MCMV or UV-MCMV on the number of lateral xanthomas as an indication of the complexity of the lesion. Lateral xanthomas were scored on hematoxylin-eosin stained paraffin sections chosen at the middle of the aortic arch. Data are expressed as mean number \pm S.E.M. $N=8$ per group. (") $P<0.05$ when compared with mock group. (\#) $P<0.05$ when compared with the UV-MCMV group. (B) Example of a Verhoeff-von Gieson stained lesion with lateral xanthomas. $\uparrow$ : indicates the xanthomatous mass adjacent to the principal lesion. $\Uparrow$ : indicates the fibrous cap of the principal lesion. Magnification 100x.

\section{Inflammatory response}

After multiple infections, no differences between the three groups were observed with respect to the number of T lymphocytes $/ \mu \mathrm{m}^{2}$ lesion. In addition, no difference was observed in the mean number of $T$ lymphocytes per microscopic field in lung, liver or salivary gland of MCMV-, UV-MCMV- and mock-injected groups. T lymphocyte numbers of the MCMV group declined to UV-MCMV and control levels (data not shown).

\section{DISCUSSION}

Various epidemiological studies have demonstrated an association between prior CMV infection and atherosclerosis ${ }^{4}$. Nonetheless, well-controlled experimental studies are needed to elucidate the etiological mechanisms 
behind the role of CMV in the atherosclerotic process. In this respect, mice prone to develop atherosclerosis are valuable tools and have been used to study the contribution of CMV to the atherosclerotic process. In apoE mice, infected with MCMV at an age of 2 weeks, a marked increase in average lesion area in the aortic sinus was observed at 16 weeks of age ${ }^{2,13}$ suggesting that CMV significantly contributes to the atherosclerotic process. Yet, in these experiments mice were infected with a high dose of MCMV $\left(3 \times 10^{4} \mathrm{PFU}\right)$, a condition that may not be representative of the human situation. In the forth decade of life, when atherosclerosis becomes manifest in humans, $50 \%$ to $85 \%$ of the general populace in the industrialized world has already encountered the virus, as shown by the high percentage of seropositives ${ }^{15}$. After the initial infection, most likely at a younger age ${ }^{12}$, CMV switches to a state of latency ${ }^{25}$ with intermittent periods of reactivation in which small amounts of infectious virus are shed. These periods of reactivation, resulting in (endogenous) reinfections, are common and may be induced by stress or other stimuli which may impair the immune system ${ }^{9,27}$. In this study we have tried to mimic this situation by infecting our apoE ${ }^{-}$mice (once or frequently) with a low copy number of MCMV $\left(10^{2}\right.$ PFU).

\section{Infection with low copy number}

Two weeks after the initial infection with $10^{2}$ PFU MCMV the majority of the internal organs as well as the aorta gave a positive signal in the standard PCR test. To determine the actual number of MCMV DNA copies in all tissues the real-time PCR technique was used. A large variation in copy number was observed between various organs ranging from almost 3000 copies $/ \mu \mathrm{g}$ total DNA in the salivary gland to less than 1 copy/ug total DNA (on average) in the aorta. A similar variation in MCMV titers has been described in previous reports 20,28 . In the aforementioned studies, both groups quantitatively analyzed infectious virus in various organs by the plaque assay and found that at 2 weeks post infection virus titers were highest in the salivary gland, whereas titers in lung, spleen and liver were comparable, but about 2 log units lower than in the salivary gland.

In addition to a single infection we infected mice 7 times with a low infectious dose of MCMV with intermittent periods of one month. The percentage of internal organs positive for MCMV DNA copies was similar between single and multiple infections. While murine regulation of MCMV replication is well established after a single infection ${ }^{1,5,10}$, less is known about immunological control mechanisms following repeated infection. Antibodies and $\mathrm{T}$ cells undoubtedly contribute to the immune process, but further studies are needed to elucidate immune responses after repetitive injections with infectious virus.

\section{Atherosclerosis}

\section{Single injection with MCMV or UV-MCMV}

When we infected $a p o E^{/ /}$mice one time with a low dose of MCMV at an age of 8 weeks, at which time only initial lesions are present in the aorta ${ }^{22}$, total lesion area was significantly increased compared with the mock-injected group. These results suggest that even low amounts of MCMV accelerate the 
atherosclerotic plaque formation in $\mathrm{apoE}^{*}$ mice. Remarkably, we also found a significant increase in mean lesion area at this time point when mice were injected with UV-MCMV. Furthermore, we observed a significant increase in T cell number in atherosclerotic plaques from mice infected with MCMV. A similar increase in T cells was observed when mice were injected with UV-MCMV.

In addition to atherosclerosis, CMV has also been associated with myocarditis, characterized by inflammation of the myocardium with necrosis of myofibres ${ }^{32,33}$. Like in the atherosclerotic plaques of our mice, T cells are also prominently present in this MCMV-induced disease ${ }^{17}$. Regarding the etiology of MCMV-induced myocarditis a number of pathogenic mechanisms have been suggested. First, it has been speculated that direct viral damage or a local viral immune response, characterized by the abundant presence of $T$ cells, may contribute to the development of myocarditis ${ }^{19}$. Secondly, a mechanism based on molecular mimicry of CMV with cardiac myosin has also been implied in pathogenesis of myocarditis following virus infection ${ }^{14,18}$. In our experiments, direct effect of the virus and/or immune response to the virus seems less important as UV-MCMV gave similar results despite the fact that no viral DNA could not be detected in the vascular wall. Alternatively, acceleration of the atherosclerotic process by MCMV may result from an autoimmune response (in which T cells directed against viral antigens may cross-react with proteins in the atherosclerotic plaque), similar to the molecular mimicry mechanism proposed for the role of $\mathrm{CMV}$ in myocarditis. In a recent study, anti-phospholipid antibodies were detected in mice following immunization with a CMV-derived peptide. In these mice an increased incidence of thrombosis and endothelial cell activation was likewise demonstrated ${ }^{8}$. Similarly, increased levels of antiphospholipid antibodies in patients have been associated with accelerated atherosclerosis in the aortic arch ${ }^{23}$. These recent findings concerning autoimmunity in disease processes inspired us to the following hypothesis:

- Inoculation with MCMV or MCMV antigens induces an immune response against MCMV antigens.

- Some of the T cells or antibodies, generated against MCMV antigens, display autoreactivity against host antigens present in the atherosclerotic vascular wall (among others).

- The autoreactive T cells invade the atherosclerotic vascular wall and accelerate the lesion formation by producing various pro-inflammatory and pro-atherogenic cytokines e.g. IFN $\gamma$, IL-1 and TNF $\alpha$ )

Nonetheless, it remains to be established which antigens are responsible for this autoimmune effect.

\section{Seven monthly injections with MCMV or UV-MCMV}

We also evaluated the effect of seven monthly injections with MCMV or UVMCMV on atherosclerotic plaque development. No significant differences were observed in plaque number and area following MCMV or UV-MCMV injection and hardly any $T$ cells were observed in lesions when compared to a single injection. With respect to the aforementioned autoimmune hypothesis, the lack of increased T cell influx in the vascular wall suggests that the composition of the atherosclerotic plaque may have changed over time. Although the plaque composition may remain relatively constant over time with respect to average 
cellular, lipid or collagen composition ${ }^{31}$, it cannot be excluded that antigens present in the early plaque may have disappeared.

When we analyzed the atherosclerotic plaques in more detail, the presence of xanthomatous masses situated adjacent to the principal lesion was observed. The number of these xanthomatous masses was significantly higher in MCMVinfected mice than in UV-MCMV or control mice. Xanthomatous masses have recently been described as accumulations of macrophages with necrotic zones consisting of lipid and/or necrotic macrophage-derived foam cells located laterally to the acellular core and immediately beneath the endothelium ${ }^{26}$. They are predominantly found in the more advanced stages of the atherosclerotic process. Since we found higher numbers in MCMV-infected mice this suggests that MCMV accelerates the formation of more advanced lesions in apoE mice. The reason why UV-MCMV didn't induce an increase in the number of xanthomas is unclear. Further detailed studies elucidating the nature of these xanthomas are needed before we can speculate on how virulent MCMV, but not UV-MCMV, may interfere with this process.

In conclusion, we demonstrated that a low, but physiologically relevant, infectious dose of MCMV ( $\left.10^{2} \mathrm{PFU}\right)$ is sufficient to infect various internal organs including atherosclerotic arteries in $a p o E^{-/}$mice. Furthermore, this low infectious dose accelerated the formation of atherosclerotic lesions. Since injection of MCMV antigens (UV-MCMV) causes a similar effect, it can be hypothesized that MCMV infections trigger this effect not by direct viral damage, but more likely via organ-specific autoimmunity.

\section{> REFERENCES}

1. Biron CA, Su HC, Orange JS. Function and Regulation of Natural Killer (NK) Cells during Viral Infections: Characterization of Responses in Vivo. Methods, 1996;9:379-393.

2. Burnett MS, Gaydos CA, Madico GE, Glad SM, Paigen B, Quinn TC, Epstein SE. Atherosclerosis in apoE knockout mice infected with multiple pathogens. $J$ Infect Dis. 2001:183:226-231.

3. Carlquist JF, Edelman L, Bennion DW, Anderson JL. Cytomegalovirus induction of interleukin6 in lung fibroblasts occurs independently of active infection and involves a $\mathrm{G}$ protein and the transcription factor, NF-kappaB. J Infect Dis. 1999;179:1094-1100.

4. Danesh J, Collins R, Peto R. Chronic infections and coronary heart disease: is there a link? [see comments]. Lancet. 1997:350:430-436.

5. Davignon JL, Clement D, Alriquet J. Michelson S, Davrinche C. Analysis of the proliferative T cell response to human cytomegalovirus major immediate-early protein (IE1): phenotype, frequency and variability. Scand J Immunol. 1995:41:247-255.

6. Espinola-Klein C, Rupprecht HJ, Blankenberg S, Bickel C, Kopp H, Rippin G, Victor A, Hafner G. Schlumberger W, Meyer J. Impact of infectious burden on extent and long-term prognosis of atherosclerosis. Circulation. 2002;105:15-21.

7. Fabricant CG, Fabricant J, Litrenta MM, Minick CR. Virus-induced atherosclerosis. J Exp Med. 1978; $148: 335-340$.

8. Gharavi AE, Pierangeli SS, Espinola RG, Liu X, Colden-Stanfield M, Harris EN. Antiphospholipid antibodies induced in mice by immunization with a cytomegalovirus-derived peptide cause thrombosis and activation of endothelial cells in vivo. Arthritis Rheum. 2002;46:545-552.

9. Glaser R, Kiecolt-Glaser JK, Speicher CE, Holliday JE. Stress, loneliness, and changes in herpesvirus latency. J Behav Med. 1985;8:249-260.

10. Hamano S, Yoshida H, Takimoto H, Sonoda K, Osada K, He X, Minamishima Y, Kimura G, Nomoto K. Role of macrophages in acute murine cytomegalovirus infection. Microbiol Immunol. 1998;42:607-616. 
11. Hendrix MG, Salimans MM, van Boven CP. Bruggeman CA. High prevalence of latently present cytomegalovirus in arterial walls of patients suffering from grade III atherosclerosis. Am J Pathol. 1990:136:23-28.

12. Ho M. Epidemiology of cytomegalovirus infections. Rev Infect Dis. 1990:12 Suppl 7:S701-710.

13. Hsich E, Zhou YF, Paigen B, Johnson TM, Burnett MS, Epstein SE. Cytomegalovirus infection increases development of atherosclerosis in Apolipoprotein-E knockout mice. Atherosclerosis. 2001;156:23-28.

14. Huber SA. Autoimmunity in myocarditis: relevance of animal models. Clin Immunol Immunopathol, 1997;83:93-102.

15. Krech U. Complement-fixing antibodies against cytomegalovirus in different parts of the world. Bull World Health Organ. 1973:49:103-106.

16. Lagneaux L, Delforge A, Snoeck R, Bosmans E, Moreau JF, Taupin JL, De Clercq E, Stryckmans $P$, Bron D. Human cytomegalovirus increases constitutive production of interleukin-6 and leukemia inhibitory factor by bone marrow stromal cells. Blood. 1996;87:5966.

17. Lawson CM, O'Donoghue $H$, Reed WD. The role of $T$ cells in mouse cytomegalovirus myocarditis. Immunology. 1989;67:132-134.

18. Lawson $\mathrm{CM}$. Evidence for mimicry by viral antigens in animal models of autoimmune disease including myocarditis. Cell Mol Life Sci. 2000;57:552-560.

19. Lenzo JC, Fairweather D, Cull V. Shellam GR, James Lawson CM. Characterisation of murine cytomegalovirus myocarditis: cellular infiltration of the heart and virus persistence. $J \mathrm{Mol} C$ ell Cardiol. 2002;34:629-640.

20. Matsuzawa $H$, Shimizu $K$, Okada $K$, Ando $K$, Hashimoto $K$, Koga $Y$. Analysis of target organs for the latency of murine cytomegalovirus DNA using specific pathogen free and germfree mice. Arch Virol. 1995;140:853-864.

21. Melnick JL, Hu C, Burek J, Adam E, DeBakey ME. Cytomegalovirus DNA in arterial walls of patients with atherosclerosis. J Med Virol. 1994:42:170-174.

22. Nakashima Y, Plump AS, Raines EW, Breslow JL, Ross R. ApoE-deficient mice develop lesions of all phases of atherosclerosis throughout the arterial tree. Arterioscler Thromb. 1994;14:133-140.

23. Pengo V, Zocche A, Scognamiglio R, Biasiolo A, Del Ros T, Ruffatti A. Accelerated atherosclerosis in the aortic arch and cerebral ischemia in a patient with primary antiphospholipid syndrome. In: Shoenfeld Y. Harats D. Wick G, eds. Atherosclerosis and autoimmunity. Amsterdam, The Netherlands: Elsevier Science B.V.; 2001: 297-300.

24. Reddick RL, Zhang SH, Maeda N. Atherosclerosis in mice lacking apo E. Evaluation of lesional development and progression [published erratum appears in Arterioscler Thromb 1994 May:14(5):839]. Arterioscler Thromb. 1994:14:141-147.

25. Roizman B, Sears AE. An inquiry into the mechanisms of herpes simplex virus latency. Annu Rev Microbiol. 1987:41:543-571.

26. Rosenfeld ME, Polinsky P, Virmani R, Kauser K, Rubanyi G, Schwartz SM. Advanced atherosclerotic lesions in the innominate artery of the ApoE knockout mouse. Arterioscler Thromb Vasc Biol. 2000:20:2587-2592.

27. Sarid $O$, Anson $O$, Yaari A, Margalith M. Human cytomegalovirus salivary antibodies as related to stress. Clin Lab. 2002;48:297-305.

28. Smee DF, Morris JL, Leonhardt JA, Mead JR, Holy A, Sidwell RW. Treatment of murine cytomegalovirus infections in severe combined immunodeficient mice with ganciclovir, (S)-1-[3hydroxy-2- (phosphonylmethoxy)propyl]cytosine, interferon, and bropirimine. Antimicrob Agents Chemother. 1992;36:1837-1842.

29. Vink C, Beuken E, Bruggeman CA. Complete DNA sequence of the rat cytomegalovirus genome. J Virol. 2000;74:7656-7665.

30. Vliegen I, Stassen F, Grauls G, Blok R, Bruggeman C. MCMV infection increases early T. lymphocyte influx in atherosclerotic lesions in apoE knockout mice. J Clin Virol. 2002;25 Suppl 2:159.

31. Wadsworth MP, Sobel BE, Schneider DJ, Taatjes DJ. Delineation of the evolution of compositional changes in atheroma. Histochem Cell Biol. 2002;118:59-68.

32. Wilson RS, Morris TH, Rees JR. Cytomegalovirus myocarditis. Br Heart J. 1972;34:865-868.

33. Wink K, Schmitz H. Cytomegalovirus myocarditis. Am Heart J. 1980;100:667-672.

34. Zhu JH, Quyyumi AA, Norman JE, Csako G, Waclawiw MA, Shearer GM, Epstein SE. Effects of total pathogen burden on coronary artery disease risk and C-reactive protein levels. $A m \mathrm{~J}$ Cardiol. 2000:85:140-146. 



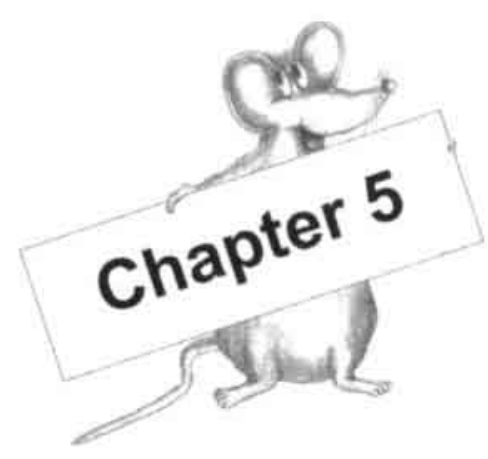

Murine cytomegalovirus infection directs macrophage differentiation into a pro-inflammatory immune phenotype: implications for atherogenesis

INGE VLIEGEN ${ }^{1}$, ADRIAN DUIJVESTIJN $^{2}$, FRANK STASSEN ${ }^{1}$, CATHRIEN $^{-}$ BRUGGEMAN ${ }^{1}$

Departments of Medical Microbiology ${ }^{1}$ and Immunology ${ }^{2}$, Cardiovascular

Research Institute Maastricht (CARIM), University of Maastricht, the Netherlands

Submitted 


\section{ABSTRACT}

We have previously demonstrated that mouse cytomegalovirus (MCMV) aggravates atherosclerosis in apolipoprotein $\mathrm{E}$ knockout (apoE $\mathrm{E}^{-1}$ ) mice by increasing $T$ cell influx in the lesions. Macrophage $(m \varphi)$ influx in the atherosclerotic plaque was not affected by MCMV despite the fact that $m \varphi$ are known to be important players in both atherosclerosis and viral clearance. In the present study we investigated whether MCMV could induce a pro-inflammatory immune $\mathrm{m} \varphi$ phenotype, thereby aggravating atherosclerosis. To this end, peritoneal exudate cells were elicited in $\mathrm{apoE}^{-1}$ mice by either MCMV or thioglycolate injection and $\mathrm{m} \varphi$ were phenotyped at 1 week post intraperitoneal injection. MCMV-induced peritoneal m $\varphi$ contained MCMV DNA but had limited MCMV mRNA expression, indicating latent infection. These $\mathrm{m} \varphi$ showed increased production of interferon- $\gamma$ (IFN $\gamma$ ), exclusive production of interleukin18 (IL-18) and increased expression of major histocompatibility complex (MHC) class II, CD40, CD80 and CD86 when compared with thioglycolate-induced $\mathrm{m} \varphi$. From these results, we conclude that intraperitoneal injection of MCMV induces an immune responsive exudate in which at 7 days post infection, MCMVinfected $\mathrm{m} \varphi$ express a pro-inflammatory immune phenotype. As such MCMVinduced $\mathrm{m} \varphi$ may contribute to aggravation of atherosclerosis through systemic and/or local immune activation. 


\section{INTRODUCTION}

Atherosclerosis, a chronic multifactorial inflammatory disease of the medium-sized and large arteries, is the principle cause of stroke, myocardial infarction and gangrene. The initial step in atherogenesis is the influx and accumulation of monocytes and T lymphocytes in the subendothelial layer after endothelial dysfunction ${ }^{33}$. This initial step is followed by monocyte-tomacrophage differentiation and macrophage $(m \varphi)$ engulfment of modified low density lipoprotein (LDL) to form foam cells ${ }^{27}$. At this point lesions are called "fatty streaks". Further lesion expansion is mediated by pro-inflammatory cytokines, chemokines, growth factors and adhesion molecules produced by inflammatory cells and activated vascular wall cells ${ }^{34}$ ultimately leading to the formation of advanced complicated lesions ${ }^{29}$. Recently, infectious agents such as cytomegalovirus (CMV) are thought to be involved in the atherosclerotic process ${ }^{4.15}$. Evidence comes from sero-epidemiological, in vitro and laboratory animal experiments. However, to validate a causative link between infection and atherosclerosis and to study the underlying contributory mechanism, additional studies are a necessity. The availability of apolipoprotein- $E$ knockout $\left(a_{0} E^{-1}\right)$ mice has made it possible to study the atherosclerotic process in more detail ${ }^{25}$. The limited number of studies that have been performed in these mice to study the contribution of CMV to atherosclerosis, describe mouse CMV (MCMV) to mediate an indirect (systemic) effect on atherosclerosis. Hsich et al. ${ }^{10}$ and Burnett et al. ${ }^{3}$ report MCMV to contribute to atherosclerosis by means of increased systemic interferon- $\gamma$ (IFN $\gamma$ ) levels in mice infected at 2 weeks of age. Since murine immune responses have not yet fully maturated in 2-week-old animals, the aforementioned model may only reflect the contribution of CMV to atherosclerosis in immune-compromised patients. To study the possible contribution of CMV to atherosclerosis in immune-competent individuals, we have previously chosen to study young adult (8-week-old) apoE $\mathrm{E}^{-1}$ mice infected with $\mathrm{MCMV}^{39}$. In our study design, MCMV was likewise shown to aggravate atherosclerosis. However, although a systemic immune response raised against the virus may to a large extent be responsible for the observed effects of MCMV on atherosclerosis, local effects in the atherosclerotic lesion cannot be excluded. Nonetheless, an increased production of pro-inflammatory cytokines and/or chemokines may be effective through both pathways.

Important sources of pro-atherogenic cytokines are $\mathrm{m} \varphi{ }^{34}$. Human studies report that in early CMV infection they may produce tumor necrosis factor- $\alpha$ $(\mathrm{TNF} \alpha)$, interleukin-1 (IL-1) and IL-6 ${ }^{11}, 32,37$. As these cytokines are important players in atherogenesis, CMV-induced cytokines may contribute to lesion progression ${ }^{8}$. Furthermore, $m \varphi$ play an important role in the immune response against $\mathrm{CMV}$ infection ${ }^{7}$. Through expression of major histocompatibility (MHC) class $\mathrm{II}$ and co-stimulatory molecules they may present viral antigen and activate antiviral Thelper cell responses ${ }^{18}$. This also leads to the production of potentially pro-atherogenic $T$ cell cytokines contributing to plaque progression. Thus, CMV may aggravate atherosclerosis by directing $\mathrm{m} \varphi$ differentiation towards a pro-inflammatory immune phenotype. So far it is unknown whether in the apoE $\mathrm{E}^{-1}$ model for atherosclerosis $\mathrm{MCMV}$ indeed directs $\mathrm{m} \varphi$ differentiation to a pro-inflammatory immune phenotype. We therefore investigated in apo $\mathrm{E}^{-1 .}$ 
mice if MCMV infection triggers $m \varphi$ to produce pro-atherogenic cytokines and express cell membrane molecules relevant for $\mathrm{T}$ cell activation.

\section{MATERIALS AND METHODS}

\section{Mice and infection protocol}

Twenty-four specific pathogen-free male $a p o E^{-/}$were purchased from Charles River, Someren, the Netherlands. They were housed in the Central Laboratory Animal Unit of our institution under standard conditions and had free access to tap water and chow diet. Stocks of Smith strain MCMV salivary gland extracts were prepared as previously described ${ }^{39}$. At the age of 8 weeks, half of the mice were intraperitoneally (i.p.) injected with $2.5 \mathrm{ml}$ of the exudateinducing compound thioglycolate $(2.4 \%$ thioglycolate medium w/o Dextrose, BD, Franklin Lakes, New Jersey), the other half were injected with $5 \times 10^{4}$ plaque forming units (PFU) of salivary gland isolated MCMV. Per injection group six mice were used for flow cytometry analysis and six were used for $m \varphi$ isolation and culture. Mouse handling and experimental procedures were conducted in accordance with institutional guidelines.

\section{Peritoneal cell harvesting}

Peritoneal exudate cells (PEC) were obtained at 1 week post i.p. injection by peritoneal lavage. After injection of $10 \mathrm{ml}$ sterile phosphate buffered saline into the peritoneal cavity of the mice, followed by massaging of the mouse abdomen, PEC were harvested. PEC were then centrifuged at $1200 \mathrm{rpm}$ at $4^{\circ} \mathrm{C}$ for $10 \mathrm{~min}$ and reconstituted in Macrophage Serum Free medium (MSFM, Gibco Invitrogen Corporation, Grand Island, New York). MSFM was chosen to prevent activation of $m \varphi$ by serum present in currently used culture media. Red blood cells were lysed with $\mathrm{NH}_{4} \mathrm{Cl}$ solution after which PEC were washed twice with MSFM and used in further experiments. All solutions and buffers were tested LPS-free by the LaL-assay (Limulus Ambocyte Lysate assay, Charles River Endosafe, Charleston, South Carolina).

\section{Cell culture and ELISA}

PEC $\left(2 \times 10^{5}\right.$ per well) were seeded in 48 well plates ( 48 well cell culture cluster, Costar, Cambridge, Massachusetts) to ensure adherence of $\mathrm{m} \varphi$ to plastic during an incubation of $2 \mathrm{~h}\left(37^{\circ} \mathrm{C}, 5 \% \mathrm{CO}_{2}\right)$. Wells were vigorously washed to remove non-adherent cells. The adherent population existed out of $\geq$ $95 \% \mathrm{~m} \varphi$. Adherent cells were incubated with $150 \mu \mathrm{l}$ fresh MSFM for 3 or $24 \mathrm{~h}$. Then, supernatants from cell cultures were collected, centrifuged to prevent interference of cells $\left(1500 \mathrm{rpm}, 3 \mathrm{~min}, 4^{\circ} \mathrm{C}\right.$ ) and analyzed for IL-12, IL-18, IL-10 and IFN $\gamma$ production using commercially available ELISA kits (IL-12p40, IL-18: BD Pharmingen, San Diego, California; IL-10, IFN $\gamma$. eBiosciences, San Diego, California). Cytokine values from thioglycolate- and MCMV-injected mice were normalized for the amount of $m \varphi$ present in the PEC. Concentrations under the lowest standard value suggested by the manufacturer $(15.6 \mathrm{pg} / \mathrm{ml}$ for IFN $\gamma$ and $\mathrm{IL}-12 \mathrm{p} 40$ and $31.3 \mathrm{pg} / \mathrm{ml}$ for IL-10 and IL-18) were defined as zero. 


\section{Flow cytometry analysis}

To estimate $\mathrm{m} \varphi$ surface marker expression, $5 \times 10^{5}$ PEC were doublestained in 96 well plates (PS-MICROPLATE, 96 WELL V-SHAPE, Greiner-Bio One $\mathrm{GmbH}$, Frickenhausen, Germany) with the antibodies described in table 1. Briefly, PEC were washed once $\left(1500 \mathrm{rpm}, 3 \mathrm{~min}, 4^{\circ} \mathrm{C}\right)$ with ice-cold MSFM followed by blocking with $10 \%$ normal mouse serum (NMS) for 30 min at $4^{\circ} \mathrm{C}$. The cells were than washed 3 times in ice-cold MSFM, re-suspended in solutions containing saturating concentrations of primary antibodies and incubated for $30 \mathrm{~min}$. After washing of the PEC, rabbit anti-rat conjugated to phycoerythrin (PE) $+3 \%$ NMS (to block cross-reactivity of PE antibody to mouse antibodies) was added for $30 \mathrm{~min}$ at $4^{\circ} \mathrm{C}$. Before adding rat anti-mouse Mac-1 fluorescein (FITC)-labeled antibody, cells were washed 3 times and incubated with $3 \%$ normal rat serum. Flow cytometry analysis (FACSCalibur, BD Biosciences, Palo Alto, California, USA) was performed on a total of 10,000 events and data analysis was done using the CellQuest (BD Biosciences) version 3.1 software package. Analysis of MHC class II, CD40, CD80 and CD86 expression on $m \varphi$ was performed by analysis of double-stained Mac-1 positive cells in the gated region reflecting the monocyte-m $\varphi$ population in thioglycolate Forward/Sideward scatter (FSC/SSC) plots. Cell viability of samples, as measured by propidium iodide (10 $\mu \mathrm{g} / \mathrm{ml}$, Calbiochem, La Jolla, California) uptake, was $\geq 96 \%$.

Table 1. List of markers and dilutions used in the flow cytometry analysis.

\begin{tabular}{|c|c|c|c|}
\hline Catalogue number & Description & Supplier & $\begin{array}{c}\text { Used } \\
\text { concentration }\end{array}$ \\
\hline \multicolumn{4}{|c|}{ PRIMARY ANTIBODIES } \\
\hline \multicolumn{4}{|l|}{ Unlabelled } \\
\hline NIMR-4 & Rat anti-mouse MHC class II & SBA, Inc. & $1 / 200$ \\
\hline MCA1143 & Rat anti-mouse CD40 & Serotec & $1 / 50$ \\
\hline MCA1586 & Rat anti-mouse CD80 & Serotec & $1 / 10$ \\
\hline MCA1587 & Rat anti-mouse CD86 & Serotec & $1 / 10$ \\
\hline \multicolumn{4}{|l|}{ Fluorescinated } \\
\hline $\mathrm{M} 1 / 70$ & $\begin{array}{l}\text { Rat anti-mouse CD11b (Mac- } \\
1 \alpha \text { chain), FITC-conjugated }\end{array}$ & $\begin{array}{c}\text { BD } \\
\text { Pharmingen }\end{array}$ & $1 / 100$ \\
\hline \multicolumn{4}{|c|}{ SECONDARY ANTIBODIES } \\
\hline STAR20A & $\begin{array}{c}\text { Rabbit anti rat lgG, PE } \\
\text { conjugated }\end{array}$ & Serotec & $1 / 5$ \\
\hline
\end{tabular}

\section{DNA and RNA isolation}

PEC $\left(2 \times 10^{5}\right.$ per well $)$ were seeded for $\mathrm{m} \varphi$ isolation. After removing nonadherent cells, $500 \mu \mathrm{l}$ TRIzol reagent (Life Technologies, GibcoBRL, Gaithersburg, Maryland) was added to the $m \varphi$. Then cells were harvested by scraping to assure optimal $\mathrm{m} \varphi$ collection. After homogenization, $100 \mu \mathrm{l}$ chloroform was added to the TRIzol samples, followed by centrifugation at 
$14000 \mathrm{rpm}$ for $10 \mathrm{~min}$ at $4^{\circ} \mathrm{C}$. The resulting upper aqueous phase containing total RNA was transferred to a fresh tube and total RNA was further isolated as described by the manufacturers and re-dissolved in $25 \mu$ ultrapure, apyrogenic water (AMPUWA $®$, Fresenius, Bad Homburg, Germany). To isolate the DNA, $250 \mu \mathrm{l}$ of $2 \mathrm{M}$ Tris- $\mathrm{HCl} \mathrm{pH}=8$ and $100 \mu \mathrm{l}$ chloroform were added to the phenolchloroform phase and interface after which the solution was vortexed for $15 \mathrm{~s}$. A centrifugation step of $10 \mathrm{~min}$ at $14000 \mathrm{rpm}$ at $4^{\circ} \mathrm{C}$ was built in and the aqueous water phase containing the DNA was transferred to a fresh tube. DNA precipitation was done by adding $500 \mu \mathrm{l}$ cold $100 \% \mathrm{EtOH}$, followed by gently mixing the solution and incubating the sample for $10 \mathrm{~min}$ at room temperature. Samples were again centrifuged for $10 \mathrm{~min}$ at $14000 \mathrm{rpm}$ at $4^{\circ} \mathrm{C}$ and the pellet was washed with $1 \mathrm{ml}$ cold $75 \% \mathrm{EtOH}$ by gently vortexing the sample followed by a centrifugation step of $5 \mathrm{~min}$ at $14000 \mathrm{rpm}$ at $4^{\circ} \mathrm{C}$. After removing the supernatant, the DNA pellet was dried for $10-15 \mathrm{~min}$ at $42^{\circ} \mathrm{C}$ and then dissolved in $25 \mu \mathrm{l}$ ultrapure, apyrogenic water. RNA and DNA samples were stored at $80^{\circ} \mathrm{C}$ until use.

\section{PCR}

To elucidate viral presence in peritoneal $m \varphi$, a MCMV-specific PCR was performed as described previously with slight modifications ${ }^{1}$. Briefly, $5 \mu \mathrm{l}$ of the DNA stocks was subjected to PCR in a total volume of $50 \mu \mathrm{l}$. To check for the presence of PCR inhibitors, each sample was spiked with 10 copies of plasmid p189-p155. This plasmid contains nucleotides 180,551 to 180,913 of the MCMV Smith genome (Immediate early-1 (IE-1) exon 4, GenBank accession number U68299), which includes the primer sequences, and an additional fragment of 138 bp cloned into the MCMV sequence, corresponding to position 215,968 to 216,096 of the rat CMV genomic sequence ${ }^{38}$. As a result of this insertion, the fragment generated by PCR from this control plasmid is $138 \mathrm{bp}$ larger than the PCR fragment that is generated from MCMV genomic DNA ( 500 bp versus 362 bp). These fragments can be easily distinguished by agarose gel electrophoresis. The reaction mixture contained $0.2 \mu \mathrm{M}$ of each primer, $10 \mathrm{mM}$ Tris $\mathrm{HCl} \mathrm{pH} 8.5,50 \mathrm{mM} \mathrm{KCl}, 3.5 \mathrm{mM} \mathrm{MgCl}, 0.2 \mathrm{mM}$ dNTPs, 1.25 units of HotStarTaq DNA polymerase (Qiagen, Leusden, the Netherlands). The PCR was performed by an initial incubation at $95^{\circ} \mathrm{C}$ for $15 \mathrm{~min}$ to activate the HotStarTaq enzyme with subsequently 40 amplification cycles consisting of denaturation at $95^{\circ} \mathrm{C}$ for $30 \mathrm{~s}$, annealing at $58^{\circ} \mathrm{C}$ for $45 \mathrm{~s}$, and extension at $72^{\circ} \mathrm{C}$ for $30 \mathrm{~s}$. After the final cycle the extension step was prolonged with $5 \mathrm{~min}$ at $72^{\circ} \mathrm{C}$ and the temperature was subsequently lowered to $15^{\circ} \mathrm{C}$. Amplification products were separated on a $1.5 \%$ ethidium bromide-stained agarose gel. The sensitivity of the PCR technique was determined to be 1 copy of the p189-p155 plasmid by gel electrophoresis.

\section{MCMV real-time RT-PCR}

To elucidate whether MCMV is present in a replicative or an inactive phase ${ }^{17 .}{ }^{36}$, on every $m \varphi$ sample positive for MCMV DNA, a real-time RT-PCR was performed to examine both "immediate early" (IE-1) and "late" (glycoprotein B (gB)) mRNA expression. After RNA isolation, a DNase treatment with DNase I (0.362 U, Amersham Pharmacia Biotech) was performed according to the 
manufacturer's instructions. Total RNA were reverse transcribed into cDNA using oligo dT (RACE-1, $1 \mathrm{pmol}$, Amersham Pharmacia Biotech) and Superscript II RNAseH (25 U, Invitrogen) according to the manufacturer's instructions. For every total RNA isolate, a RT-PCR reaction was also performed in the absence of the reverse transcriptase, to demonstrate the specific amplification of mRNA instead of genomic DNA. Real-time PCR reactions on CDNA were performed by the ABI Prism 7000 in a final volume of $25 \mu \mathrm{l}$. Reaction mixtures included $12.5 \mu \mathrm{l}$ of TaqMan universal master mix $(2 \mathrm{x}$ concentrated, Applied Biosystems), $300 \mathrm{nM}$ of forward primer, $300 \mathrm{nM}$ reverse primers, $200 \mathrm{nM}$ probe and $5 \mu \mathrm{l}$ CDNA sample. Primers and probes for the detection of MCMV were based on the MCMV gB sequence (GenBank accession number M735191, forward primer 5'-AGGGCTTGGAGAGGACCTAC A-3', reverse primer 5'-GCCCGTCGGCAGTCTAGTC-3' and probe 5'AGCTAGACGACAGCCAACGCAACGA-3'). The probe carried a 5' 6carboxyfluorescein (FAM) reporter and a 3' 6-carboxy-tetramethyl-rhodamine (TAMRA) quencher group. For amplification of IE-1 the primers 5'CAACATTGACCACGCACTAGATG-3' (forward primer) and 5'-TTAAACTCCCC AGGCAATGAA-3 (900 nM, reverse primer) and the probe 5'-TCTTGGCCCATG CGGCACG-3' (FAM and TAMRA labeled) were used. Thermal cycling started with uracyl-N-glycosylase (UNG) activation for $2 \mathrm{~min}$ at $50^{\circ} \mathrm{C}$, followed by HotStarTaq activation during $10 \mathrm{~min}$ at $95^{\circ} \mathrm{C}$. Thereafter 42 cycles of amplification were run consisting of $15 \mathrm{~s}$ at $95^{\circ} \mathrm{C}$ (denaturation) and 1 minute at $60^{\circ} \mathrm{C}$ (annealing \& extension). To analyze the amount of target sequence present in the sample, a statistically determined threshold fluorescence limit is determined as 10 standard deviations above the mean background fluorescence during cycles 3-15. The interpolated cycle at which the fluorescence time course reaches this threshold is than determined and is known as the threshold cycle (Ct). This is the unit used for all subsequent quantifications and the $\mathrm{Ct}$ value is irreversibly related to the starting copy number of the target sequence.

\section{Statistical analysis}

Results are shown as mean \pm S.E.M. Statistical differences between experimental groups were analyzed by the two-sided non-parametric MannWhitney $U$-test. $P<0.05$ was considered as statistically significant.

\section{RESULTS}

\section{Cytokine production by $m \varphi$}

Eight-week-old atherosclerosis-sensitive apoE ${ }^{-1-}$ mice were i.p. injected with the well-known exudate-inducing compound thioglycolate or with MCMV to study the effect of MCMV injection on (peritoneal) $m \varphi$ phenotypic differentiation at 7 days post injection (p.i.). The apoE ${ }^{-l}$ model was chosen in order to relate the observed results to MCMV-mediated aggravation of atherosclerosis in an in vivo model. We used eight-week-old mice as atherosclerosis starts at this age in apoE $E^{-1}$ mice ${ }^{25}$. PEC were collected at 7 days p.i. to allow development of $m \varphi$ differentiation ${ }^{9}$. Production of IL-12, IL-18, IL-10 and IFN $\gamma$ was measured by 
ELISA in supernatants from peritoneal $m \varphi$ cultured for 3 or $24 \mathrm{~h}$. As shown in table $1, \mathrm{IL}-18$ was exclusively produced by MCMV-induced peritoneal $\mathrm{m} \varphi$ and IFN $\gamma$ production was significantly higher than by thioglycolate-induced $m \varphi$. The decline in IFN $\gamma$ and IL-18 levels at $24 \mathrm{~h}$ may reflect fading of the in vivo induced effects over time. No IL-10 production was seen in either group at either early or late time points and IL-12 production was not significant different between both groups. Thus, MCMV-induced peritoneal $\mathrm{m} \varphi$ show an increased production of pro-inflammatory immune cytokines compared to $m \varphi$ stimulated by thioglycolate.

Table 2. Cytokine levels in supernatant of macrophages isolated from MCMV- and thioglycolate-injected mice after culturing for 3 and $24 \mathrm{~h}$.

\begin{tabular}{|c|c|c|c|c|}
\hline & \multicolumn{4}{|c|}{ Tissue culture } \\
\hline & \multicolumn{2}{|c|}{$3 \mathrm{~h}$} & \multicolumn{2}{|c|}{$24 \mathrm{~h}$} \\
\hline & $\begin{array}{l}\text { Thioglycolate } \\
\text { (pg/ml) }\end{array}$ & $\begin{array}{l}\text { MCMV } \\
\text { (pg/ml) }\end{array}$ & $\begin{array}{l}\text { Thioglycolate } \\
(\mathrm{pg} / \mathrm{ml})\end{array}$ & $\begin{array}{l}\text { MCMV } \\
(\mathrm{pg} / \mathrm{ml})\end{array}$ \\
\hline IL 10 & 0 & 0 & 0 & 0 \\
\hline IL 12p40 & $32.19 \pm 25.39$ & $61.15 \pm 35.51$ & $80.92 \pm 53.19$ & $70.69 \pm 28.16$ \\
\hline IL 18 & 0 & $16.62 \pm 12.37$ & 0 & $6.07 \pm 6.64$ \\
\hline IFN $\gamma$ & $4.55 \pm 4.99$ & $50.28 \pm 23.54$ * & $5.38 \pm 5.89$ & $19.66 \pm 11.55$ \\
\hline
\end{tabular}

Data are expressed as mean \pm S.E.M. $N=6$ per group. ( $\left.{ }^{*}\right) P<0.05$ as determined by 2 -sided nonparametric Mann-Whitney $U$ test.

\section{Expression of $T$ cell activating molecules by $m \varphi$}

In addition to cytokine production, the peritoneal exudate $\mathrm{m} \varphi$ population was studied phenotypically by flow cytometry analysis. As demonstrated by their FSC/SSC plots at 7 days p.i., the thioglycolate-induced exudates included a distinct large population of $\mathrm{m} \varphi$ and minor populations of granulocytes and lymphocytes (Fig. 1 A). Thioglycolate-induced $m \varphi$ were predominantly large "thioglycolate-stuffed" cells and were highly pure in the gated FSC/SSC monocyte-m $\varphi$ window as shown by Mac-1 positivity $(98.34 \pm 0.45 \%)$. In the MCMV-induced exudates the m $\varphi$ population was less distinct in the FSC/SSC plots than in the thioglycolate exudates. Predominantly small "non-stuffed" $m \varphi$ were present, overlapping the lymphocyte population as shown by the presence of $50.95 \pm 4.14 \%$ Mac- 1 negative cells in the monocyte-m $\varphi$ window as set for thioglycolate $m \varphi$. 
A

a

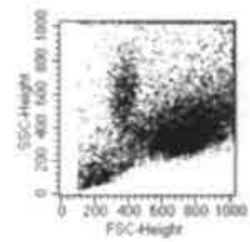

B

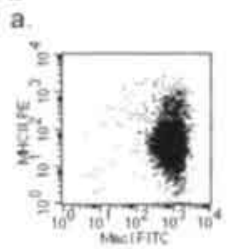

b.

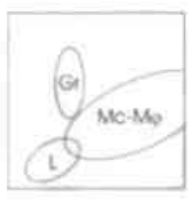

c.

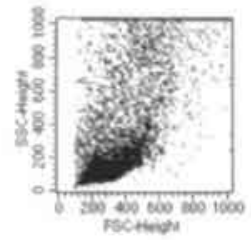

b.

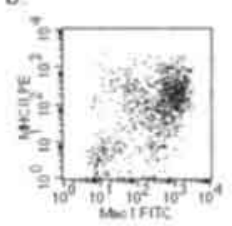

c.

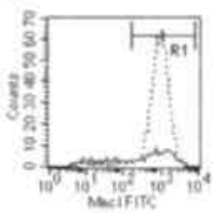

d.

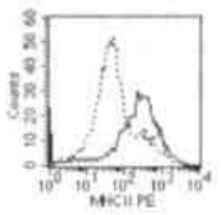

Fig. 1. Representative plots of peritoneal exudate composition and immune marker expression on the macrophage cell membrane at 1 week after MCMV and thioglycolate injection. (A) (a \& c) Representative FSC/SSC plots of the peritoneal exudate composition of (a) thioglycolate- and (c) MCMV-injected mice. (b) Schematic drawing of the major cell population

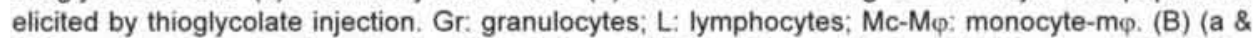
b) Representative dot plot of a double staining of PEC for Mac-1 FITC and MHC class II PE in the gated monocyte-m $\varphi$ population as set in the thioglycolate elicited PEC. (a) thioglycolate-elicited exudate (b) MCMV-elicited exudate. (c) Representative histogram of the Mac-1 stained PEC of the thioglycolate-injected (--) and the MCMV-infected (-) mouse shown in (a) and (b). R1 indicates the population of macrophages (Mac-1 positive) in the gated region (d) Representative histogram showing MHC class II fluorescent staining of the R1 (Mac-1 positive) cell population.

To determine phenotypic differentiation of $m \varphi$ towards an immune ( $T$ cell activating) phenotype, $\mathrm{m} \varphi$ expression of MHC class II, CD40, CD80 and CD86 molecules was measured. Therefore, Mac-1 positive cells present in the monocyte-m $\varphi$ gated FSC/SSC window as set in the thioglycolate exudates were analyzed for these molecules by double staining. As shown in figs. $1 \mathrm{~B}$ and 2 , MCMV-induced $m \varphi$ showed significantly higher mean fluorescence for MHC class II, CD40, CD80, CD86 when compared with thioglycolate-induced peritoneal Mac-1 positive cells. Thus, these data suggest that, although there is a lower contribution of $\mathrm{m} \varphi$ in the peritoneal exudate after MCMV injection than after thioglycolate injection, the expression of immune markers is significantly increased on the MCMV-induced $\mathrm{m} \varphi$ population. 


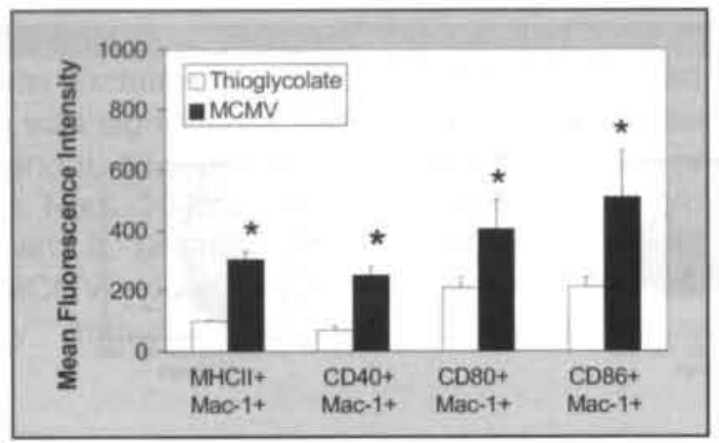

Fig. 2. Mean fluorescence intensity levels of immune markers on the peritoneal macrophage (Mac-1 positive) cell membrane of thioglycolate-injected and MCMV-infected mice. Values are expressed as mean \pm S.E.M. ( $\left.{ }^{*}\right) P<0.05$ as determined by 2 -sided non-parametric Mann-Whitney $U$ test.

\section{Detection of MCMV DNAIRNA in peritoneal $m \varphi$}

To determine whether $m \varphi$ phenotypical differentiation was the result of $m \varphi$ infection or merely $m \varphi$ triggering, MCMV DNA presence was determined in the peritoneal $m \varphi$ by MCMV PCR. At 7 days post i.p. injection all thioglycolateinduced peritoneal $m \varphi$ samples were negative for MCMV DNA, while all MCMVinduced peritoneal $\mathrm{m} \varphi$ samples showed MCMV DNA (Fig. 3).

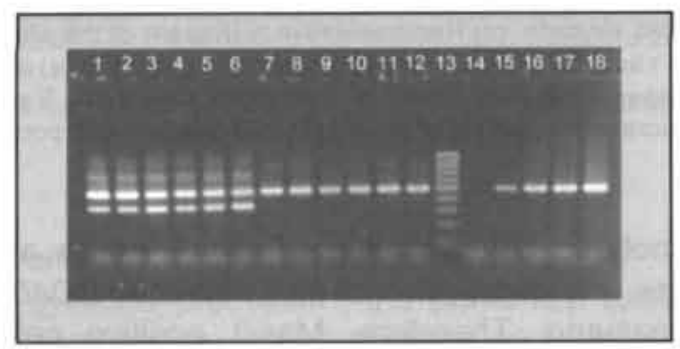

Fig. 3. Ethidium bromide-stained agarose gel showing MCMV genomic DNA and/or control plasmid DNA amplified by MCMV PCR from MCMV- or thioglycolate-elicited $m \varphi D N A$ samples spiked with control plasmid DNA. The fragment generated by PCR from the control plasmid (p189-p155) is 138 bp larger than the PCR fragment that is generated from MCMV genomic DNA. Lanes 1-6: MCMV-elicited m $\varphi$ DNA samples spiked with 10 copies of plasmid p189-p155; 7-12: thioglycolate-elicited m $\varphi$ DNA samples spiked with 10 copies of plasmid p189-p155; 13: molecular weight marker; 14: negative water control. Lanes 15-18: p189-p155 DNA: 15, 1 copy; 16, 10 copies; $17,10^{2}$ copies; $18,10^{3}$ copies.

In addition, a real-time RT-PCR assay was used to detect IE-1 mRNA expression on the PCR positive samples to elucidate whether MCMV is present in a replicative or an inactive phase ${ }^{17.36}$. Since the reproductive cycle of MCMV may be interrupted at any time during replication ${ }^{20 .}{ }^{23}$, we also determined the expression of the "late" gene gB by real-time RT-PCR. Only 2 out of 6 samples showed IE-1 expression and in these samples high $\mathrm{Ct}$ (threshold cycle) values 
of 37 and 38 were seen. These Ct values theoretically reflect 50 and 25 mRNA copies, respectively. For gB expression, only 1 sample out of 6 (equaling 1 out of 2 samples positive for $(\mathrm{E}-1$ ) was found positive and the $\mathrm{Ct}$ value was 38 . The observed data indicate that the $m \varphi$ phenotypic differentiation after MCMV injection is related to an active i.e. replicative MCMV infection evolving to latent infection at 7 days p.i.

\section{DISCUSSION}

In this paper, we investigated $\mathrm{m} \varphi$ differentiation towards a pro-inflammatory immune phenotype following $\mathrm{MCMV}$ infection in atherogenic apo $\mathrm{E}^{-/}$mice. Hence, mice were intraperitoneally injected with MCMV and peritoneal $\mathrm{m} \varphi$ were harvested 7 days post injection. Mice injected with thioglycolate, a well-known $\mathrm{m} \varphi$ inducer, were used for comparison. By using the PCR technique we evaluated the presence of MCMV in these peritoneal $\mathrm{m} \varphi$ at 7 days p.i.. MCMV DNA could be detected in all $m \varphi$ isolated from MCMV- but not thioglycolateinjected mice. However, since viral replication was limited at 7 days p.i. as shown by the real time RT-PCR data, the presence of MCMV DNA in these me could reflect either a non-productive infection or phagocytosed MCMV. Fish et al. ${ }^{5}$ described human CMV to be able to evade lysosomal fusion thereby escaping from phagocytic destruction by monocyte-derived $m \varphi$. Thus, the presence of MCMV DNA in the MCMV-induced peritoneal $m \varphi$ most likely reflects latent MCMV. MCMV infection resulted in increased IFN $\gamma$ secretion and exclusive IL-18 production of peritoneal $\mathrm{m} \varphi$. These cytokines are important proinflammatory/immune cytokines, playing a role in protection against intracellular pathogens including $\mathrm{CMV}^{14,22,30,31}$. Although IFN $\gamma$ is classically described as a prototypical $\mathrm{T}$ helper 1 cytokine, recent evidence suggests that $\mathrm{m} \varphi$ may also be able to produce IFN $\gamma$ in response to IL-18 stimulation ${ }^{24}$. Furthermore, in combination with IL-12, IFN $\gamma$ production by $m \varphi$ is significantly enhanced. This may explain the significant difference in IFN $\gamma$ production between the experimental groups. Nonetheless, we cannot exclude that contaminating cells contributed to the measured IFN $\gamma$ levels in the $m \varphi$ cultures ${ }^{6}$. However, since contaminating cells made up $<5 \%$ of the total population a major contribution is unlikely. IL-10 was not produced by thioglycolate- nor MCMV-induced $m \varphi$. Since IL-10 is considered an anti-inflammatory cytokine, the absence of this cytokine supports our results that MCMV induces a pro-inflammatory immune $\mathrm{m} \varphi$ phenotype. That MCMV infection indeed induces a pro-inflammatory immune $\mathrm{m} \varphi$ phenotype was also reflected by the increased expression of the immune markers MHC class II, CD40, CD80 and CD86 involved in antigen presentation to $\mathrm{T}$ cells. MHC class $\mathrm{II}$ is described to play a role in antigen presentation to $\mathrm{CD}^{+} \mathrm{T}$ cells ${ }^{28,40}$ and after co-stimulation through molecules such as CD40, CD80 and CD86, CD4 ${ }^{+} \mathrm{T}$ cell activation (e.g. cytokine expression) and proliferation/differentiation takes place ${ }^{12,16,42}$. In the $\mathrm{m} \varphi$ window of the MCMV-induced exudates a relatively large population of lymphocytes was observed. Although these lymphocytes were identified as Mac-1 negative (presumably T cells), the presence of Mac-1 positive B cells expressing MHC class II, CD40, CD80 and CD86 can not be excluded. 
However, since only a subpopulation of B cells express Mac-1 and as a significant contribution of $B$ cells to the exudates is unlikely, these interferences can be expected negligible. In brief, MCMV infection of $\mathrm{m} \varphi$ appears to direct $\mathrm{m} \varphi$ differentiation towards a pro-inflammatory immune phenotype, with proinflammatory cytokine production and increased expression of immune markers involved in antigen presentation to T cells.

$A p o E^{-1}$ mice, which spontaneously develop atherosclerosis, were used in this study to allow extrapolation of $m \varphi$ data to the role of MCMV in atherosclerosis. The data from the present study suggest MCMV to be able to influence the disease by inducing phenotypic differentiation towards proinflammatory immune $m \varphi$. These MCMV-induced $m \varphi$ may either systemically or locally (after migration to the vascular wall) affect atherosclerosis by increasing cytokine production and enhancing MCMV antigen presentation to $\mathrm{T}$ cells. Indeed, CD40 signaling in atheromas has been described to impact atherosclerosis at all stages ${ }^{35}$. There is also abundant expression of human leucocyte antigen (HLA) class II molecules in human atherosclerotic lesions ${ }^{13}$ and $\mathrm{m} \varphi \mathrm{MHC}$ class II, CD80 and CD86 expression may allow m $\varphi$ to present internalized oxidized LDL ${ }^{19,26}$. Furthermore, IL-18 has been found in human atherosclerotic plaques and is related to plaque instability ${ }^{21}$ and for IFN $\gamma$ it has been described that exogenous administration aggravates atherosclerosis in apoE ${ }^{-1-}$ mice ${ }^{41}$. Also in an other atherogenic model, the LDL receptor knockout mouse, IFN $\gamma$ influences the extent and phenotype of diet-induced atherosclerosis ${ }^{2}$. Nonetheless, to further extent and unequivocally confirm the contribution of these pro-inflammatory immune $m \varphi$, additional experiments, like transfer studies with labeled MCMV-induced $m \varphi$, will need to be performed.

In summary, MCMV infection leads to $\mathrm{m} \varphi$ differentiation towards a proinflammatory immune phenotype. This differentiation results in increased proinflammatory immune cytokine production and increased expression of immune markers on the macrophage membrane relevant to processes aggravating atherosclerosis. Preliminary data from studies with isolated $m \varphi$ infected with $M C M V$ in vitro show that MCMV infection directly induces increased production of IL-18 and IL-12 (unpublished observations). Thus, also in the used in vivo exudate model the effect on $m \varphi$ differentiation may be directly mediated by CMV infection and not necessarily through $\mathrm{T}$ cell interaction.

\section{ACKNOWLEDGEMENTS}

The authors would like to thank Mohamed Hadfoune, Henk van Rie, Peter Heijmans and Maria Vroomen for technical support and Patrick Beisser for his assistance in preparing the flow cytometry figures.

\section{REFERENCES}

1. Balthesen $M$, Messerle $M$, Reddehase MJ. Lungs are a major organ site of cytomegalovirus latency and recurrence. $J$ Virol. 1993;67:5360-5366. 
2. Buono C, Come CE, Stavrakis G, Maguire GF, Connelly PW, Lichtman AH, Influence of interferon-gamma on the extent and phenotype of diet-induced atherosclerosis in the LDLRdeficient mouse. Arterioscler Thromb Vasc Biol. 2003:23:454-460.

3. Burnett MS, Gaydos CA. Madico GE, Glad SM, Paigen B, Quinn TC, Epstein SE. Atherosclerosis in apoE knockout mice infected with multiple pathogens. I Infect Dis. 2001:183:226-231.

4. Epstein SE, Zhou YF, Zhu J. Infection and atherosclerosis: emerging mechanistic paradigms. Circulation. 1999;100:e20-28.

5. Fish KN, Britt W, Nelson JA. A novel mechanism for persistence of human cytomegalovirus in macrophages. J Virol. 1996;70:1855-1862.

6. Golab J, Zagozdzon, Stoklosal T, Kaminski R, Kozar K, Jakobisiak M. Direct stimulation of macrophages by IL-12 and IL-18--a bridge too far? Immunol Lett. 2000;72:153-157.

7. Hamano S, Yoshida H, Takimoto H, Sonoda K, Osada K, He X, Minamishima Y, Kimura G, Nomoto K. Role of macrophages in acute murine cytomegalovirus infection. Microbiol Immunol. 1998:42:607-616.

8. Hansson GK. Immune mechanisms in atherosclerosis. Arterioscler Thromb Vasc Biol. 2001:21:1876-1890.

9. Hendrix MGR, Bruggeman CA, van Boven CPA. Alterations of the functional state of peritoneal macrophages during rat cytomegalovirus infection in vivo. FEMS Microbiology Letters. 1986;33:111-115.

10. Hsich E, Zhou YF, Paigen B, Johnson TM, Burnett MS, Epstein SE. Cytomegalovirus infection increases development of atherosclerosis in Apolipoprotein-E knockout mice. Atherosclerosis. 2001:156:23-28.

11. Iwamoto GK, Monick MM, Clark BD, Auron PE, Stinski MF, Hunninghake GW. Modulation of interleukin 1 beta gene expression by the immediate early genes of human cytomegalovirus. $J$ Clin Invest. 1990:85:1853-1857.

12. Jenkins MK, Khoruts A, Ingulli E, Mueller DL, McSorley SJ, Reinhardt RL, Itano A, Pape KA. In vivo activation of antigen-specific CD4 T cells. Annu Rev Immunol. 2001:19:23-45.

13. Jonasson L, Holm J, Skalli O, Gabbiani G, Hansson GK. Expression of class II transplantation antigen on vascular smooth muscle cells in human atherosclerosis. J Clin Invest. 1985;76:125. 131.

14. Kawakami K, Qureshi MH, Zhang T, Okamura H, Kurimoto M, Saito A. IL-18 protects mice against pulmonary and disseminated infection with Cryptococcus neoformans by inducing IFNgamma production. J Immunol. 1997;159:5528-5534.

15. Kol A, Libby $P$. The mechanisms by which infectious agents may contribute to atherosclerosis and its clinical manifestations. Trends Cardiovasc Med. 1998;8:191-199.

16. Kuchroo VK, Das MP, Brown JA, Ranger AM, Zamvil SS, Sobel RA, Weiner HL, Nabavi N, Glimcher LH. B7-1 and B7-2 costimulatory molecules activate differentially the Th1/Th2 developmental pathways: application to autoimmune disease therapy. Cell. 1995;80:707-718.

17. Kurz S, Steffens HP, Mayer A, Harris JR, Reddehase MJ. Latency versus persistence or intermittent recurrences: evidence for a latent state of murine cytomegalovirus in the lungs. $J$ Virol. 1997; 71:2980-2987.

18. Le Roy E, Baron M, Faigle W, Clement D, Lewinsohn DM, Streblow DN, Nelson JA, Amigorena S, Davignon JL. Infection of APC by human cytomegalovirus controlled through recognition of endogenous nuclear immediate early protein 1 by specific $\operatorname{CD} 4(+) T$ lymphocytes. J Immunol. 2002;169:1293-1301.

19. Lee TS, Yen HC, Pan CC, Chau LY. The role of interleukin 12 in the development of atherosclerosis in ApoE-deficient mice. Arterioscler Thromb Vasc Biol. 1999;19:734-742.

20. Lucin P, Jonjic S, Messerle M, Polic B, Hengel H, Koszinowski UH. Late phase inhibition of murine cytomegalovirus replication by synergistic action of interferon-gamma and tumour necrosis factor. J Gen Virol. 1994:75:101-110.

21. Mallat Z, Corbaz A, Scoazec A, Besnard S, Leseche G, Chvatchko Y, Tedgui A. Expression of interleukin-18 in human atherosclerotic plaques and relation to plaque instability. Circulation. 2001:104:1598-1603.

22. Mastroeni $P$, Clare $S$, Khan $S$, Harrison JA, Hormaeche $C E$, Okamura $H$, Kurimoto $M$, Dougan G. Interleukin 18 contributes to host resistance and gamma interferon production in mice infected with virulent Salmonella typhimurium. Infect Immun. 1999;67:478-483.

23. Mocarski ES. Cytomegaloviruses and their replication. In: Fields BN, Knipe DM, Howley PM. eds. Fields Virology. Philadelphia: Lippincott-Raven Publishers; 1996: 2447-2492. 
24. Munder M, Mallo M, Eichmann K, Modolell M. Murine macrophages secrete interferon gamma upon combined stimulation with interleukin (IL)-12 and IL-18: A novel pathway of autocrine macrophage activation. J Exp Med. 1998;187:2103-2108.

25. Nakashima Y, Plump AS, Raines EW, Breslow JL, Ross R. ApoE-deficient mice develop lesions of all phases of atherosclerosis throughout the arterial tree. Arterioscler Thromb. 1994;14:133-140.

26. Nicoletti A, Caligiuri G, Tornberg I, Kodama T, Stemme S, Hansson GK. The macrophage scavenger receptor type A directs modified proteins to antigen presentation. Eur J Immunol. 1999;29:512-521.

27. Pentikainen MO, Oorni K, Ala Korpela M, Kovanen PT. Modified LDL-trigger of atherosclerosis and inflammation in the arterial intima. J Intern Med. 2000;247:359-370.

28. Pieters J. MHC class II-restricted antigen processing and presentation. Adv Immunol. 2000;75:159-208.

29. Pietila K. Nikkari T. Role of the arterial smooth muscle cell in the pathogenesis of atherosclerosis. Med Biol. 1983;61:31-44.

30. Pomeroy C, Delong D, Clabots C, Riciputi P, Filice GA. Role of interferon-gamma in murine cytomegalovirus infection. J Lab Clin Med. 1998;132:124-133.

31. Presti RM, Pollock JL, DalCanto AJ, AK OG, Virgin HW. Interferon gamma regulates acute and latent murine cytomegalovirus infection and chronic disease of the great vessels. J Exp Med. 1998;188:577-588.

32. Pulliam L, Moore D, West DC. Human cytomegalovirus induces IL-6 and TNF alpha from macrophages and microglial cells: possible role in neurotoxicity. J Neurovirol. 1995;1:219-227.

33. Ross R. The pathogenesis of atherosclerosis: a perspective for the 1990s. Nature. 1993;362:801-809.

34. Saadeddin SM, Habbab MA, Ferns GA. Markers of inflammation and coronary artery disease. Med Sci Monit. 2002;8:RA5-12.

35. Schonbeck U, Libby P. CD40 signaling and plaque instability. Circ Res. 2001;89:1092-1103.

36. Sinclair J, Sissons P. Latent and persistent infections of monocytes and macrophages. Intervirology. 1996;39:293-301.

37. Smith PD, Saini SS, Raffeld M, Manischewitz JF, Wahl SM. Cytomegalovirus induction of tumor necrosis factor-alpha by human monocytes and mucosal macrophages. J Clin Invest. 1992;90:1642-1648.

38. Vink C, Beuken E, Bruggeman CA. Complete DNA sequence of the rat cytomegalovirus genome. J Virol, 2000;74:7656-7665.

39. Vliegen I, Stassen F, Grauls G, Blok R, Bruggeman C. MCMV infection increases early Tlymphocyte influx in atherosclerotic lesions in apoE knockout mice. J Clin Virol. 2002;25 Suppl 2:159,

40. Watts C. Capture and processing of exogenous antigens for presentation on MHC molecules. Annu Rev Immunol. 1997;15:821-850.

41. Whitman SC, Ravisankar P. Elam H, Daugherty A. Exogenous interferon-gamma enhances atherosclerosis in apolipoprotein E-/- mice. Am J Pathol. 2000;157:1819-1824.

42. Yang $Y$, Wilson JM. CD40 ligand-dependent $T$ cell activation: requirement of $B 7-C D 28$ signaling through CD40. Science. 1996;273:1862-1864. 




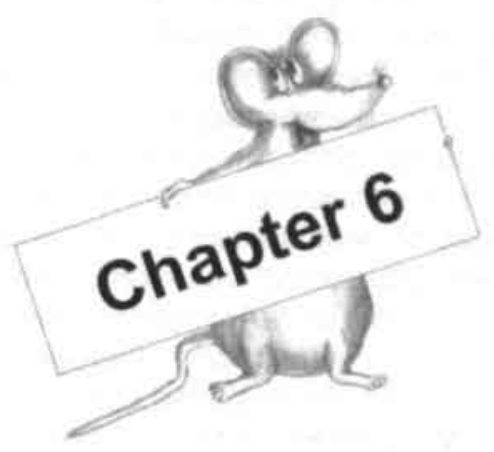

Cytomegalovirus infection aggravates atherogenesis in apoE knockout mice by 6oth local and systemic immune activation

\footnotetext{
INGE VLIEGEN ${ }^{1}$, ADRIAN DUIJVESTIJN ${ }^{2}$, GERT GRAULS ${ }^{1}$, SELMA HERNGREEN ${ }^{i}{ }^{1}$, CATHRIEN BRUGGEMAN $^{1}$, FRANK STASSEN ${ }^{1}$

Departments of Medical Microbiology ${ }^{1}$ and Immunology ${ }^{2}$, Cardiovascular Research Institute Maastricht (CARIM), University of Maastricht, the Netherlands
}

Microbes Infect, in press 


\section{ABSTRACT}

Since the 1970 's cytomegalovirus (CMV) infection has been associated with atherosclerotic disease. However, the exact contribution of the virus remains uncertain. In this article we describe both a direct and indirect immune-mediated effect of the virus on the disease process. Therefore, 8-week-old apoE knockout mice were mouse CMV (MCMV) infected or mock injected and they were sacrificed at 2 and 20 weeks post injection (p.i.) to study atherosclerosis, vascular wall IFN $\gamma$ and TNF $\alpha$ expression and MCMV spread. To study plasma IFN $\gamma$ and TNF $\alpha$ levels, blood was collected at 1, 2, 4 and 6 days p.i. in addition to days of sacrifice. Plasma cytokine levels were increased after MCMV infection at early time points and decreased to mock levels at 2 and 20 weeks p.i. At 2 weeks p.i. more aortic arch samples showed local cytokine expression after MCMV infection. Early atherosclerotic lesion numbers and the percentage of mice containing early lesions were increased at 2 weeks p.i., while at 20 weeks p.i. the MCMV-induced effect on atherogenesis was seen on the advanced lesions. In conclusion, MCMV infection induces a systemic immune response reflecting an indirect effect of MCMV infection on atherosclerosis in addition to a local aortic immune response reflecting a direct effect of the virus on the atherosclerotic process. 


\section{INTRODUCTION}

A variety of risk factors such as hyperlipidemia, diabetes and smoking have been associated with atherosclerosis. Although these factors do explain variations in pathogenesis, prevalence and severity of atherosclerosis, atherogenesis cannot be fully assigned to them. About one century ago it was already recognized that infections may be an additional risk factor for atherosclerosis ${ }^{8,31}$. In 1978 Fabricant et al. demonstrated experimental evidence for a viral contribution in atherosclerosis ${ }^{7}$. Subsequent research showed that besides Marek's disease virus also another herpesvirus i.e. cytomegalovirus (CMV) is associated with atherosclerosis. The virus has been detected inside the cells of the vascular wall ${ }^{16,32}$ and CMV seropositivity is associated with an increased risk for carotid and coronary artery disease ${ }^{28,56}$. In addition, experimental evidence has accumulated on the potential mechanisms underlying the pathogenic role of CMV in atherosclerosis: (1) CMV can induce smooth muscle cell migration and proliferation ${ }^{26,57},(2) \mathrm{CMV}$ increases modified LDL uptake in vascular smooth muscle cells ${ }^{55}$ and (3) CMV infection of endothelial cells induces an increase in expression of adhesion molecules ${ }^{2}$.

These studies are all indicative for a contribution of CMV in the atherosclerotic disease process. However, as human atherosclerosis is a complex multistep process, with multiple confounding factors like environmental factors and gender differences which may potentially obscure the effect of CMV infection on the disease process $17,18,22,30,37$, there is a need for a wellcontrolled atherosclerosis-sensitive animal model to study the true causal role of CMV in atherosclerosis. In addition, atherosclerosis can only be produced in living animals and not in in vitro models, again pointing out the need for animal models. Recent gene-targeting technology provided mouse models which provide good insight into atherogenesis ${ }^{133}$. The apolipoprotein $E$ knockout $\left(\mathrm{apoE}^{-1}\right.$ ) mouse on a C57BL/6J background is a extensively studied model of atherosclerosis ${ }^{29,34,38,54}$. This mouse model lacks apoE, which participates in the hepatic clearance of cholesterol-rich LDL from the plasma. These mice acquire high plasma total cholesterol levels and develop severe atherosclerotic plaques that resemble human atherogenesis.

Previous studies using this mouse model demonstrated that infections with the mouse variant of human CMV, MCMV, increased atherosclerotic lesion size 4. 19. However, in these studies mice were infected at 2 weeks of age, a time point at which the immune system is not fully maturated and MCMV infection cannot be efficiently attacked by the host immune system. The aggravating contribution of CMV on atherosclerosis seen in these study may therefore only reflect the MCMV-mediated effect on atherosclerosis in immune-compromised hosts. Therefore in this study we infected 8-week-old apoE ${ }^{-1 /}$ mice and evaluated atherosclerotic lesion formation, the presence of the virus in the vascular wall as well as systemic and local pro-inflammatory cytokine production at 2 and 20 weeks post infection in an attempt to study the effect of the virus in an immuno-competent host. 


\section{MATERIALS AND METHODS}

\section{Animals and infection protocol}

Forty eight-week-old specific pathogen-free (SPF) apoE mice on a C57BL/6J background were obtained from Charles River, Someren, the Netherlands. They were housed under standard conditions, fed ad libitum with standard mouse chow diet and had free access to water. Half of the mice were infected with salivary-gland isolate of mouse cytomegalovirus $\left(5 \times 10^{4} \mathrm{PFU}\right.$, Smith strain), the other half was mock-injected with sterile PBS. Mice were sacrificed at 2 weeks post injection (p.i., $n=12$ ) or at 20 weeks p.i. $(n=12)$. In addition $15 \mathrm{apoE}^{-/}$mice $(\mathrm{n}=7 \mathrm{MCMV}$-infected and $\mathrm{n}=8$ mock-injected) were used to study cytokine expression in the aortic arch at 2 weeks p.i. The Ethical Committee for the Use of Laboratory Animals of the institution approved all procedures carried out in these mice.

\section{Tissue collection}

At $1,2,4$ and 6 days p.i. plasma was collected from all mice by retro-orbital puncture. At 2 and 20 weeks p.i. mice were anaesthetized with a weightadjusted dose of pentobarbital followed by blood collection by left ventricular puncture. After exsanguination, the arterial tree was perfused at $100 \mathrm{mmHg}$ with PBS via a catheter in the left ventricular apex. Subsequently a part of lung, liver, salivary gland and spleen, together with the descending aorta (thoracic and abdominal) were collected and snap frozen in liquid nitrogen. Organs were stored at $-70^{\circ} \mathrm{C}$ until the MCMV PCR assay was performed. In addition, the aortic arch was removed and fixed overnight in 3.7\% formaldehyde, embedded in paraffin and $4 \mu \mathrm{m}$ longitudinal sections were cut. The additional $15 \mathrm{apoE}^{\prime-}$ mice were perfused after exsanguination at 2 weeks p.i. and aortic arch, carotid arteries and thoracic aorta were pooled, snap frozen in liquid nitrogen and stored at $-70^{\circ} \mathrm{C}$ up until RNA isolation for cytokine measurements.

\section{Atherosclerotic disease progression}

The middle paraffin section of the aortic arch was collected, stained with hematoxylin-eosin and total lesion area, lesion type, mean lesion number and lesion complications (xanthomas) were scored. All morphometric parameters were determined using a microscope coupled to a computer-assisted morphometry system (ANALYSIS ${ }^{2}$, Soft Imaging System $\mathrm{GmbH}$, Germany) as described before ${ }^{51}$. Lesion type was scored according to the guidelines of the American Heart Association ${ }^{48}$ with type I-III being classified as early lesions and type IV-V as advanced lesions. During analysis, multiple lateral xanthomas flanking the fibrofatty nodules (as recently described by Rosenfeld et al. ${ }^{39}$ ) were observed in the mice at 20 wk p.i. The mean number and total area of these lateral xanthomas were scored and compared between groups.

\section{MCMV detection by PCR}

From all organs, DNA was isolated using the Wizard genomic DNA purification kit (Promega) according to the manufacturer. MCMV specific DNA amplification was done as described before ${ }^{51}$ with minor modifications to increase sensitivity. Briefly, the reaction mixture contained $0.2 \mu \mathrm{M}$ of each primer, $10 \mathrm{mM}$ Tris $\mathrm{HCl} \mathrm{pH} 8.5,50 \mathrm{mM} \mathrm{KCl}, 3.5 \mathrm{mM} \mathrm{MgCl}, 0.2 \mathrm{mM}$ dNTPs, 
1.25 units of HotStarTaq DNA polymerase (Qiagen, Leusden, the Netherlands) and $1 \mu \mathrm{g}$ DNA in a total volume of $50 \mu \mathrm{l}$. To exclude PCR inhibition, each sample was spiked with 10 copies of plasmid p189-p155. In addition to the nucleotides 180,551 to 180,913 of the MCMV Smith genome (Immediate early-1 (IE-1) exon 4, GenBank accession number U68299) which were present in the p189 plasmid used in the previous study, in the p189-p155 plasmid an additional fragment of 138 bp was cloned into the MCMV sequence, corresponding to position 215,968 to 216,096 of the RCMV genomic sequence ${ }^{50}$. As a result of this insertion, the fragment generated by PCR from this control plasmid is $138 \mathrm{bp}$ larger than the PCR fragment that is generated from MCMV genomic DNA (500 bp versus 362 bp). These fragments can be easily distinguished by agarose gel electrophoresis. The PCR program included 15 min at $95^{\circ} \mathrm{C}$ followed by 40 amplification cycles consisting of denaturation at $95^{\circ} \mathrm{C}$ for $30 \mathrm{~s}$, annealing at $58^{\circ} \mathrm{C}$ for $1 \mathrm{~min}$, and extension at $72^{\circ} \mathrm{C}$ for $1 \mathrm{~min}$. After the final cycle the extension step was prolonged for $5 \mathrm{~min}$ at $72^{\circ} \mathrm{C}$ and the temperature was subsequently lowered to $15^{\circ} \mathrm{C}$. Amplification products were separated on a $1.5 \%$ ethidium bromide-stained agarose gel. The sensitivity of the PCR technique was determined to be 1 copy of the p189-p155 plasmid.

\section{Detection of aortic TNF $\alpha$ and IFN $\gamma$ mRNA expression by real-time RT-PCR}

Cytokine expression in the pooled snap frozen arteries was determined by real-time RT-PCR. Tissue was homogenized and total RNA was isolated with TRIzol $^{\otimes}$ reagent according to the instructor's manual for samples with high protein content. Thereafter a DNase treatment with DNase I (0.362 U, Amersham Pharmacia Biotech) was performed according to the manufactures instructions. Equal amounts of total RNA were reverse transcribed into cDNA, using oligo dT (RACE-1, 1 pmol, Amersham Pharmacia Biotech) and Superscript II RNAseH (25 U, Invitrogen) according to the manufactures instructions. For every total RNA isolate also a RT-PCR reaction was performed in the absence of the reverse transcriptase, to demonstrate the specific amplification of mRNA and not genomic DNA. Real-time PCR reactions on cDNA were performed by the ABI Prism 7000 in a final volume of $25 \mu \mathrm{l}$. The mixture contained the following components: $12.5 \mu \mathrm{l}$ of TaqMan universal master mix ( $2 x$ concentrated, Applied Biosystems), $300 \mathrm{nM}$ of forward primer, $900 \mathrm{nM}$ reverse primers in the case of IFN $\gamma$ or $300 \mathrm{nM}$ in the case of TNF $\alpha$ and GAPDH, $200 \mathrm{nM}$ probe and $0.15 \mu \mathrm{g}$ cDNA sample. Primers and probes for IFN $\gamma$, TNF $\alpha$ and GAPDH amplification are described in table 1. Thermal cycling started with UNG activation for $2 \mathrm{~min}$ at $50^{\circ} \mathrm{C}$, followed by HotStarTaq activation during $10 \mathrm{~min}$ at $95^{\circ} \mathrm{C}$. Thereafter 42 cycles of amplification were performed consisting of $15 \mathrm{~s}$ at $95^{\circ} \mathrm{C}$ and 1 minute at $60^{\circ} \mathrm{C}$. A negative control, containing reagents only was included in each run. Relative differences between TNF $\alpha$ and IFN $\gamma$ levels per group were determined by dividing for every sample the mean $\mathrm{Ct}$ (Threshold cycle) value of GAPDH by the mean $\mathrm{Ct}$ value of TNF $\alpha$ and IFN $\gamma$. This method was used to compensate for possible fluctuations in total RNA input in the real-time RT-PCR. 
Table 1. Summary of primers used to determine cytokine mRNA levels by the real-time RTPCR.

\begin{tabular}{|c|c|c|c|c|}
\hline & Forward primer & Reverse primer & Probe & Labels probe \\
\hline IFNy & $\begin{array}{l}\text { 5.CAGCAACAGC } \\
\text { AAGGCGAAA-3 } \\
(300 \mathrm{nM})\end{array}$ & $\begin{array}{l}\text { 5.-GCTGGATTCC } \\
\text { GGCAACAG-3' } \\
(900 \mathrm{nM})\end{array}$ & $\begin{array}{l}\text { 5.CAAGTITGAG } \\
\text { GTCAACAACCCACAG } \\
\text { GTCC-3' (200 nM) }\end{array}$ & $\begin{array}{l}\text { 5' FAM reporter } \\
\text { 3' TAMRA quencher }\end{array}$ \\
\hline TNF $\alpha$ & $\begin{array}{l}\text { 5. CATCTTCTCA } \\
\text { AAATTCGAGTGAC } \\
\text { AA-3' (300 nM) }\end{array}$ & $\begin{array}{l}\text { 5-TGGGAGTAGA. } \\
\text { CAAGGTACAACC } \\
\text { C- } 3 \text { ' }(300 \mathrm{nM})\end{array}$ & $\begin{array}{c}\text { 5'-CACGTCGTAG } \\
\text { CAAACCACCAAGTGG } \\
\text { A-3' (200 nM) }\end{array}$ & $\begin{array}{l}\text { 5' FAM reporter } \\
\text { 3' DABSYL quencher }\end{array}$ \\
\hline GAPDH & $\begin{array}{l}\text { 5. CATTGTGGAA } \\
\text { GGGCTCATGA-3' } \\
(300 \mathrm{nM})\end{array}$ & $\begin{array}{l}\text { 5-GCCCCACGGC } \\
\text { CATCA-3' } \\
\text { (300 nM) }\end{array}$ & $\begin{array}{c}\text { 5.AGTCCATGCC } \\
\text { ATCACTGCCACCC-3 } \\
(200 \mathrm{nM})\end{array}$ & $\begin{array}{l}5 \text { ' JOE reporter } \\
\text { 3. TAMRA quencher }\end{array}$ \\
\hline
\end{tabular}

\section{Cytokine production in plasma}

At $1,2,4,6,14$ and 140 days p.i. TNF $\alpha$ and IFN $\gamma$ plasma levels were determined by the ELISA method (eBiosciences, San Diego, California) using the manufactures protocol. Values were quantified using a standard curve from $1000 \mathrm{pg} / \mathrm{ml}-15.625 \mathrm{pg} / \mathrm{ml}$ and data under the lowest standard value were defined as zero.

\section{Statistics}

Data are expressed as mean \pm S.E.M. One-sided non-parametric analysis were performed with the Mann-Whitney $U$-test to determine statistical significant differences between MCMV- and mock-injected groups. Differences were regarded statistical significant when $P<0.05$.

\section{RESULTS}

\section{MCMV detection}

Although no MCMV DNA could be detected in any of the mock-injected mice, at 2 weeks after MCMV infection, $100 \%$ of the salivary glands, spleens and lungs were positive for MCMV DNA, 92\% of the livers were positive and $67 \%$ of the aorta were positive. At 20 weeks p.i. the percentage of organs positive for MCMV DNA had declined to $83 \%$ for the salivary glands, $50 \%$ for the spleens and lungs, $17 \%$ for the livers and no aorta were positive.

\section{Atherosclerotic disease progression}

In 10-week-old apoE ${ }^{-*}$ mice atherosclerosis was limited. Only type 1 (initial lesions), type 2 (fatty streak lesions) and type 3 lesions (intermediate lesions, 1 lesion in 1 mouse), grouped as early lesions, were observed. At the age of 28 weeks atherosclerosis had aggravated, which was reflected by a disperse panel of lesion types in our mice (all but type 6: ruptured lesion).

When we established atherosclerotic disease severity (percentage of mice containing lesions, total lesion area and mean number of lesions/mouse) in apoE either 2 weeks after MCMV infection or mock injection we found a higher 
percentage of MCMV-infected mice with lesions. More MCMV-infected mice contained type 1 and type 3 lesions and significantly more MCMV-infected mice contained type 2 lesions when compared with the mock-injected groups (Table 2).

Table 2. Percentage of mock- and MCMV-injected mice containing lesions at 2 weeks post infection.

\begin{tabular}{|c|c|c|c|c|}
\hline \multicolumn{1}{|c|}{ Type 1 } & Type 2 & Type 3 & Total \\
\hline mock & $63.64 \%$ & $45.45 \%$ & $0 \%$ & $81.82 \%$ \\
\hline MCMV & $83.33 \%$ & $91.67 \%$ * & $8.3 \%$ & $91.67 \%$ \\
\hline
\end{tabular}

(*) $P<0.05$ as determined by the one-sided the Mann-Whitney U-test

Furthermore, when examining mean lesion numbers per mice positive for lesions, significantly more (early) lesions were observed after MCMV infection at 2 weeks p.i. (Fig. 1). These findings suggest that MCMV accelerates atherosclerotic disease progression. However, total lesion area was not different between the mock- and MCMV-injected group at 2 weeks p.i.

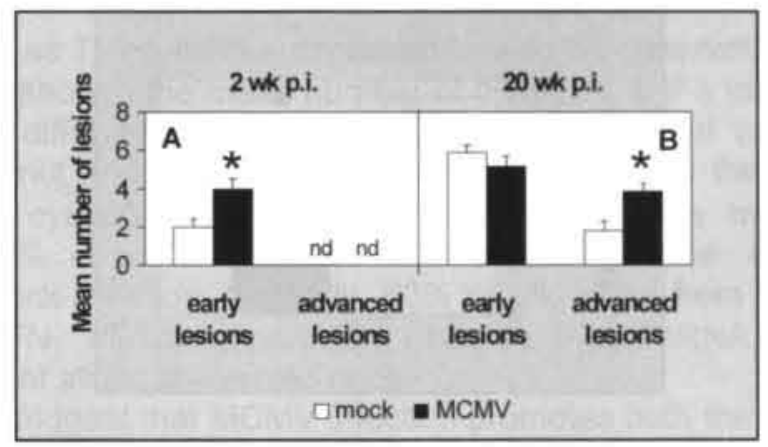

Fig. 1. Mean early lesion (type 1-3) and advanced lesion (type 4-5) number at 2 weeks (A) and 20 weeks (B) after mock or MCMV injection. The data represent the average number of lesions \pm S.E.M. scored on the middle hematoxylin-eosin stained paraffin section of the aortic arch. (") $P<0.05$ as determined by the Mann-Whitney $U$-test. $\mathrm{N}=12$ mice /group. $\mathrm{n} . \mathrm{d}$. = not detectable.

At 20 weeks p.i., the significant increase in lesion number observed at the acute phase after infection remained but was shifted from early to advanced lesions (Fig. 1). In addition, MCMV infection increased advanced lesion area (Fig. 2). 


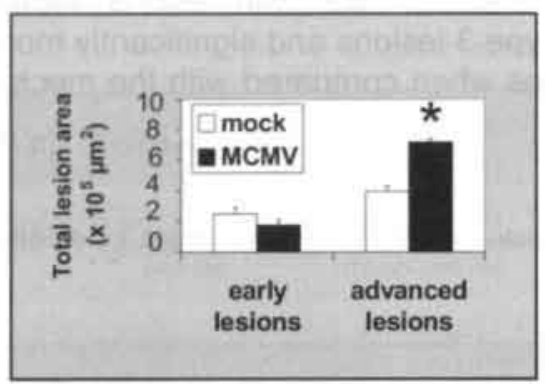

Fig. 2. Mean early lesion (type 1-3) and advanced lesion (type 4-5) area at 20 weeks post mock or MCMV injection. The data represent total lesion area \pm S.E.M. scored on the middle hematoxylin-eosin stained paraffin section of the aortic arch using a microscope coupled to a computer-assisted morphometry system (ANALYSIS ${ }^{8}$, Soft Imaging System GmbH, Germany). (") $P<0.05$ as determined by the Mann-Whitney $U$-test. $N=12$ mice /group.

Finally, the number of xanthomas per mouse was scored at the chronic phase of injection (Fig. 3). As indicated by Rosenfeld et al. ${ }^{39}$, xanthomas are predominantly seen at the advanced stages of atherosclerosis and are defined as accumulations of macrophages with necrotic zones consisting of lipid and/or necrotic macrophage-derived foam cells located laterally to the a-cellular core and immediately beneath the endothelium. The increase in xanthoma number, as seen in fig. 3, may therefore reflect an aggravation of atherosclerosis in the MCMV-infected mice at 20 weeks p.i. when compared with the mock group.

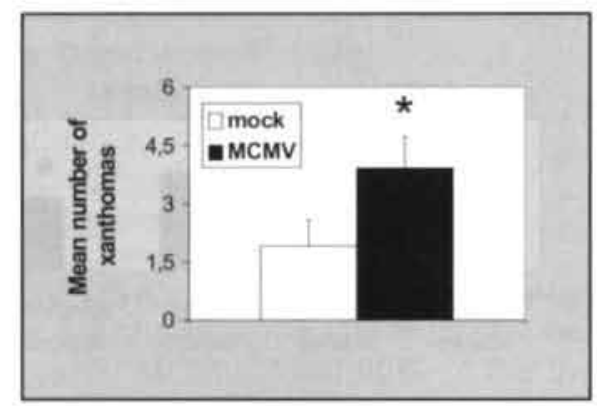

Fig. 3. Number of xanthomas scored at 20 weeks post mock or MCMV injection. Xanthomas, defined as accumulations of macrophages with necrotic zones consisting of lipid and/or necrotic macrophage-derived foam cells located laterally to the acellular core and immediately beneath the endothelium, reflect lesion complexity. Data are expressed as mean number \pm S.E.M. (") P<0.05 as determined by the Mann-Whitney U-test. $\mathrm{N}=12$ mice /group.

\section{Inflammation}

Both systemic as well as local responses of the immune system following MCMV infection were determined. Systemic immune responses were identified by increases in circulating plasma levels of IFN $\gamma$ and TNF $\alpha$, while an increased 
expression of IFN $\gamma$ and TNF $\alpha$ mRNA in the descending aorta was considered as a local immune response following MCMV infection.

Following MCMV infection, TNF $\alpha$ titers increased in $\mathrm{apoE}^{-/}$mice at 2 days p.i., reached their peak level at 4 days p.i. and declined to zero at 6 days p.i. In the mock-injected group no TNF $\alpha$ production could be seen (Fig. $4 \mathrm{~A}$ ). Comparing both groups, TNF $\alpha$ titers were significantly higher in the MCMV group than in the mock group at 2 and 4 days p.i. For IFN $\gamma$, high peak levels were seen at 2 days after MCMV infection, which thereafter gradually declined to zero at 6 days p.i. In the mock group only low levels of IFN $\gamma$ expression were seen. As for TNF $\alpha$, IFN $\gamma$ levels were significantly higher in the MCMV group than in the mock group (Fig. 4 B).

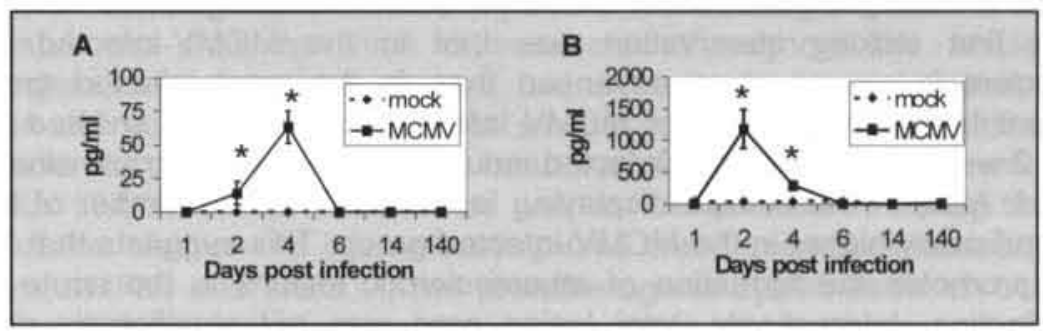

Fig. 4. TNF $\alpha$ (A) and IFN $\gamma$ (B) plasma titers at 1, 2, 4, 6, 14, 140 days post mock or MCMV injection. Titers were determined by ELISA and expressed as mean levels \pm S.E.M. (*) $P<0.05$ as determined by the Mann-Whitney U-test. $\mathrm{N}=12$ mice /group.

IFN $\gamma$ as well as TNF $\alpha$ mRNA expression could be observed in both groups at 2 weeks p.i. Although the mean number of IFN $\gamma$ and TNF $\alpha$ mRNA copies did not significantly differ between mice from both groups that expressed these cytokines (data not shown), differences were observed in the percentage of aortas showing cytokine mRNA expression. While TNF $\alpha$ mRNA could be detected in $100 \%$ of all aortas from MCMV-infected mice, only $67 \%$ were positive after mock-injection. Similarly, $60 \%$ of all aortas from MCMV-infected mice showed IFN $\gamma$ mRNA expression whereas IFN $\gamma$ mRNA could only be detected in $25 \%$ of all mock-injected mice.

These data suggest that MCMV infection promotes both the local as well as the systemic production of pro-inflammatory cytokines, which thereby may contribute to the progression of the atherosclerotic lesion formation.

\section{DISCUSSION}

Atherosclerotic lesions are sites of chronic inflammation in the vascular wall characterized by the presence of cells as well as soluble mediators of both the innate and adaptive immune system ${ }^{14,41}$. Macrophages have been shown to play a crucial role in the development of the atherosclerotic plaque while also $T$ cells are abundant in atheroma ${ }^{13,44}$. An important question that remains to be 
answered is what causes this immune activation and the subsequent influx of immune cells into the subendothelial layer. It has been suggested that specific immune responses directed against autoantigens present in the vascular wall can initiate and/or maintain the atherosclerotic process ${ }^{53}$. In addition, evidence is accumulating that infections may contribute significantly to arterial inflammation. Manifold epidemiological studies demonstrated an increased risk for cardiovascular complication such as myocardial infarction and stroke in particular in patients with high antibody titers against various infectious pathogens ${ }^{5}$. Nonetheless, due to ethical reasons it is fairly impossible to study the real contribution of infection to atherogenesis in humans. Fortunately, recent progress in gene targeting technology provided the scientific community with good animals models, such as apoE ${ }^{\%}$ and LDLrec $^{-/}$mice, to study the process of atherosclerosis ${ }^{21,29,34}$. In this study we used these apoE ${ }^{-/ *}$ mice to examine the acute and long-term effects of CMV infections on atherogenesis.

Our first striking observation was that in the MCMV-infected group atherosclerosis seems more advanced than in the mock-injected group. A significant higher percentage of MCMV infected mice already showed type II lesions 2 weeks p.i., while in 1 infected mouse a type III lesion could already be detected. Also, in those mice displaying lesions, the mean number of lesions was significantly higher in the MCMV-infected group. This suggests that MCMV indeed promotes the formation of atherosclerotic lesions in the acute phase after infection. Interestingly, total lesion area was not significantly different between both groups. We also determined these parameters at a time point when the acute infection has already been resolved, e.g. 20 weeks postinfection. Intriguingly, at this time point the number of advanced lesions was significantly increased in the MCMV group while no differences were observed in early lesion number. This suggests that the initial effect of MCMV infection, e.g. an increased number of early lesions, is maintained in time. Also, a significant increase in total area of advanced lesions was observed. Furthermore, a significant increase in the number of lateral xanthomas was observed flanking these advanced lesions. Xanthomas have previously been described by Rosenfeld et al. ${ }^{39}$ as being accumulations of macrophages with necrotic zones consisting of lipid and/or necrotic macrophage-derived foam cells located laterally to the acellular core and immediately beneath the endothelium and thus may be interpreted as complications of initial lesions. Based on these data it may be concluded that an acute MCMV infection invigorates the formation of early atherosclerotic lesions in apoE $\mathrm{E}^{-}$mice while in the long run it may stimulate the formation of more complex lesions. As lesion complexity may be a more important denominator for the severity of the disease process, this may provide a potential mechanism by which CMV increases the risk for future complications. Furthermore, our data demonstrate that CMV may not only affect atherogenesis in apoE ${ }^{*}$ mice infected at a young age when the immune system is not fully developed ${ }^{4,19}$ but also when the immune system in these mice is fully maturated.

In studies on the role of CMV on the pathogenesis of atherosclerosis, it is difficult to distinguish between direct pathogen-mediated vascular disease and the immune-mediated inflammatory response. Most likely, the effect of CMV infection on atherosclerosis results from a cascade of events. Therefore, in this 
study we evaluated whether MCMV elicits direct pro-atherogenic effects in the vessel wall and/or indirect effects resulting from immune activation following MCMV infection.

\section{Direct effects}

Direct pathogen-mediated effects may include stimulation of smooth muscle cells proliferation/migration ${ }^{57}$, increased lipid accumulation ${ }^{55}$ and endothelial dysfunction ${ }^{35}$, which all contribute to the initiation and/or progression of atherosclerosis ${ }^{40}$. However, a direct effect may require the presence of the virus in the vascular wall at some time after infection. Therefore, we examined the presence of MCMV DNA in aortas of our apoE $\mathrm{E}^{-/ .}$mice at 2 and 20 weeks p.i. At 2 weeks, MCMV DNA could be detected in $67 \%$ of the aortas isolated from infected mice. MCMV DNA could also be detected in various other organs such as the liver, spleen, lung and salivary gland demonstrating that the infection was successful and that the virus disseminated throughout the whole body. Nonetheless, in a previous study ${ }^{51}$ we already demonstrated that MCMV infection did not alter endothelial or smooth muscle cell composition of the atherosclerotic plaque. On the other hand, we observed a marked increase in T cell influx in both the aortic sinus as well as the aortic arch during the acute phase of the infection. As it is well recognized that $T$ cell activation leads to the secretion of IFN $\gamma$ and TNF $\alpha^{14}$, two pro-atherogenic cytokines which both have been implicated in atherogenesis, we determined the expression of IFN $\gamma$ and TNF $\alpha$ mRNA in the vascular wall following MCMV infection. Interestingly, while IFN $\gamma$ and TNF $\alpha$ mRNA could only be detected in 25 and $67 \%$ of the aortic arches from apoE $E^{-1}$ mice following mock injection, respectively, mRNA for these 2 cytokines could be detected in 60 and $100 \%$ of MCMV infected mice. These data suggest that MCMV infection indeed has a direct effect on the atherosclerotic process by stimulating the local production of pro-inflammatory and pro-atherosclerotic cytokines, such as IFN $\gamma$ and TNF $\alpha$.

\section{Indirect effect}

After primary cytomegalovirus infection, the host immune system limits viral replication, resulting into silent disease. The innate immunity, consisting of NK cells, macrophages and cytokines, acts as a first line of defense against viral infections ${ }^{15,25}$. Thereafter the adaptive immunity is activated to eliminate the virus via specific T cells and antibodies ${ }^{11}$. NK cells were initially defined by their ability to lyse virally infected cells, but to leave normal host cells intact ${ }^{23}$. They predominantly secrete IFN $\gamma$, the prototypical macrophage-activating cytokine, which also can have direct effects on viral replication ${ }^{36}$. On the other hand, macrophages are described to produce TNF $\alpha$ at early times during MCMV infection ${ }^{9.45}$. This innate antiviral immune response was demonstrated in our study by a significant increase in both IFN $\gamma$ and TNF $\alpha$ plasma levels at 2 days after MCMV infection. At about 2-4 days p.i. the adaptive immune system is switched on by the innate immune system. Virus-specific $T$ cells will perform their effector functions after recognition, including the production of antiviral cytokines, especially IFN $\gamma$ and $\operatorname{TNF} \alpha{ }^{6,43}$. This is revealed in our study by the retained significant higher plasma IFN $\gamma$ and TNF $\alpha$ titers at 4 days p.i. Nevertheless, this systemic increase in IFN $\gamma$ and TNF $\alpha$ may not only be 
important in fighting the viral infection. As mentioned before ${ }^{13}$, TNF $\alpha$ promotes numerous inflammatory reactions associated with atherosclerosis including the induction of vascular adhesion molecules, the recruitment of monocyte/macrophages and the proliferation of smooth muscle cells. Likewise, multiple studies demonstrated that IFN $\gamma$ could severely accelerate lesions development and atherosclerotic disease progression ${ }^{3}, 12,52$. Recently, Epstein's group demonstrated that IFN $\gamma$-containing serum isolated from MCMV infected mice induced the expression of monocyte chemoattractant protein-1 (MCP-1) expression by endothelial cells ${ }^{42}$. This may result in an increased influx and differentiation of monocytes/macrophages into the vascular wall and the initiation of new atherosclerotic lesion. Interestingly, we found indeed a significant increase in the number of early lesions in young mice shortly after MCMV infection. Since monocytes are assumed to be transporter cells for CMV 20. 24, 27. 47, MCP-1 expression may also lead to attraction of (latently) infected monocytes. Subsequent differentiation into macrophages may then reactivate latently present $\mathrm{CMV}^{46,49}$. In addition, intimate contact between monocytes and vascular cells might also reactivate CMV from infected monocytes ${ }^{10}$ and mediate direct effects on atherosclerosis in the vascular wall.

In summary, our data demonstrate that MCMV infection accelerates the formation of early atherosclerotic lesions in 8-week-old apoE mice. This effect is maintained in the long run and results in more complex lesions at 20 weeks p.i. Furthermore, we found evidence that this aggravation results from both a direct effect of MCMV in the lesion itself (presence of MCMV DNA and an increased production of pro-inflammatory cytokines in the aortic arch) as well as an indirect effect (increased levels of systemic pro-inflammatory cytokines) thereby providing some new mechanisms by which CMV infections may contribute to atherosclerosis.

\section{ACKNOWLEDGEMENTS}

The authors would like to thank Monique Vergouwe for her technical support.

\section{REFERENCES}

1. Breslow JL. Mouse models of atherosclerosis. Science. 1996;272:685-688.

2. Bruggeman CA, van Dam Mieras MC. The possible role of cytomegalovirus in atherogenesis. Prog Med Virol. 1991;38:1-26.

3. Buono C, Come CE, Stavrakis G, Maguire GF, Connelly PW, Lichtman AH. Influence of interferon-gamma on the extent and phenotype of diet-induced atherosclerosis in the LDLRdeficient mouse. Arterioscler Thromb Vasc Biol. 2003;23:454-460.

4. Burnett MS, Gaydos CA, Madico GE, Glad SM, Paigen B, Quinn TC, Epstein SE. Atherosclerosis in apoE knockout mice infected with multiple pathogens. $J$ Infect Dis. 2001:183:226-231.

5. Danesh J. Collins R. Peto R. Chronic infections and coronary heart disease: is there a link? [see comments]. Lancet. 1997;350:430-436.

6. Davignon JL, Castanie P, Yorke JA, Gautier N, Clement D, Davrinche C. Anti-human cytomegalovirus activity of cytokines produced by $C D 4+T$-cell clones specifically activated by IE1 peptides in vitro. $J$ Virol. 1996;70:2162-2169. 
7. Fabricant CG, Fabricant J, Litrenta MM, Minick CR. Virus-induced atherosclerosis. J Exp Med. 1978:148:335-340.

8. Frothingham $C$. The relation between acute infectious diseases and arterial lesions. Arch Intern Med. 1911:8:153-162.

9. Geist LJ, Monick MM, Stinski MF, Hunninghake GW. The immediate early genes of human cytomegalovirus upregulate tumor necrosis factor-alpha gene expression. J Clin Invest. 1994:93:474-478.

10. Guetta E, Guetta V, Shibutani T, Epstein SE. Monocytes harboring cytomegalovirus: interactions with endothelial cells, smooth muscle cells, and oxidized low-density lipoprotein. Possible mechanisms for activating virus delivered by monocytes to sites of vascular injury. Circ Res. 1997;81:8-16.

11. Guidotti LG, Chisari FV. Noncytolytic control of viral infections by the innate and adaptive immune response. Annu Rev Immunol. 2001:19:65-91.

12. Gupta S, Pablo AM, Jiang $X$, Wang N, Tall AR, Schindler C. IFN-gamma potentiates atherosclerosis in ApoE knock-out mice. J Clin Invest. 1997:99:2752-2761.

13. Hansson GK. Immune mechanisms in atherosclerosis. Arterioscler Thromb Vasc Biol. 2001;21:1876-1890.

14. Hansson GK, Libby $P$, Schonbeck $U$, Yan ZQ. Innate and adaptive immunity in the pathogenesis of atherosclerosis. Circ Res. 2002:91:281-291.

15. Heise MT, Virgin HWt. The T-cell-independent role of gamma interferon and tumor necrosis factor alpha in macrophage activation during murine cytomegalovirus and herpes simplex virus infections. J Virol. 1995;69:904-909.

16. Hendrix MG, Daemen M, Bruggeman CA. Cytomegalovirus nucleic acid distribution within the human vascular tree. Am J Pathol. 1991:138:563-567.

17. Hochner-Celnikier D, Manor O, Gotzman O, Lotan H, Chajek-Shaul T, Gender gap in coronary artery disease: comparison of the extent, severity and risk factors in men and women aged 45 65 years. Cardiology. 2002;97:18-23.

18. Hornstra G, Barth CA, Galli C, Mensink RP. Mutanen M, Riemersma RA, Roberfroid M. Salminen K, Vansant G, Verschuren PM. Functional food science and the cardiovascular system. Br J Nutr. 1998;80 Suppl 1:S113-146.

19. Hsich E, Zhou YF, Paigen B, Johnson TM, Burnett MS, Epstein SE. Cytomegalovirus infection increases development of atherosclerosis in Apolipoprotein-E knockout mice. Atherosclerosis. 2001:156:23-28.

20. Ibanez CE, Schrier R, Ghazal P, Wiley C, Nelson JA. Human cytomegalovirus productively infects primary differentiated macrophages. J Virol. 1991;65:6581-6588.

21. Ishibashi S, Goldstein JL, Brown MS, Herz J, Burns DK. Massive xanthomatosis and atherosclerosis in cholesterol-fed low density lipoprotein receptor-negative mice. $J$ Clin Invest. 1994;93:1885-1893

22. Kaplan JR, Manuck SB. Using ethological principles to study psychosocial influences on coronary atherosclerosis in monkeys. Acta Physiol Scand Suppl. 1997;640:96-99.

23. Kiessling R, Klein E, Wigzell H. "Natural" killer cells in the mouse. I. Cytotoxic cells with specificity for mouse Moloney leukemia cells. Specificity and distribution according to genotype. Eur J Immunol. 1975;5:112-117.

24. Lathey JL, Spector SA. Unrestricted replication of human cytomegalovirus in hydrocortisonetreated macrophages. J Virol. 1991;65:6371-6375.

25. Lee SH, Webb JR, Vidal SM. Innate immunity to cytomegalovirus: the Cmv1 locus and its role in natural killer cell function. Microbes Infect. 2002;4:1491-1503.

26. Lemstrom KB, Bruning JH, Bruggeman CA, Lautenschlager IT, Hayry PJ. Cytomegalovirus infection enhances smooth muscle cell proliferation and intimal thickening of rat aortic allografts. J Clin Invest. 1993;92:549-558.

27. Maciejewski JP, Bruening EE, Donahue RE, Sellers SE, Carter C, Young NS, St Jeor S. Infection of mononucleated phagocytes with human cytomegalovirus. Virology. 1993;195:327. 336.

28. McDonald K, Rector TS, Braulin EA, Kubo SH, Olivari MT. Association of coronary artery disease in cardiac transplant recipients with cytomegalovirus infection. Am J Cardiol. 1989;64:359-362.

29. Nakashima Y, Plump AS, Raines EW, Breslow JL, Ross R. ApoE-deficient mice develop lesions of all phases of atherosclerosis throughout the arterial tree. Arterioscler Thromb. $1994 ; 14: 133-140$. 
30. Neison TL, Vogler GP, Pedersen NL, Hong Y, Miles TP. Genetic and environmental influences on body fat distribution, fasting insulin levels and CVD; are the influences shared? Twin Res. 2000;3:43-50.

31. Ophüls W. Arteriosclerosis and cardiovascular disease: their relation to infectious diseases. JAMA. 1921;76:700-701.

32. Petrie BL, Melnick JL, Adam E, Burek J, McCollum CH, DeBakey ME. Nucleic acid sequences of cytomegalovirus in cells cultured from human arterial tissue. J Infect Dis. 1987;155:158-159.

33. Plump A. Atherosclerosis and the mouse: a decade of experience. Ann Med. 1997:29:193-198.

34. Plump AS, Smith JD, Hayek T, Aalto Setala K, Walsh A, Verstuytt JG, Rubin EM, Breslow JL. Severe hypercholesterolemia and atherosclerosis in apolipoprotein E-deficient mice created by homologous recombination in ES cells. Cell. 1992;71:343-353.

35. Prasad A, Zhu J, Halcox JP, Waclawiw MA, Epstein SE, Quyyumi AA. Predisposition to atherosclerosis by infections: role of endothelial dysfunction. Circulation. 2002;106:184-190.

36. Presti RM, Popkin DL, Connick M, Paetzold S, Virgin HWt. Novel cell type-specific antiviral mechanism of interferon gamma action in macrophages. J Exp Med. 2001:193:483-496.

37. Price JF, Fowkes FG. Risk factors and the sex differential in coronary artery disease. Epidemiology. 1997:8:584-591.

38. Reddick RL, Zhang SH, Maeda N. Atherosclerosis in mice lacking apo E. Evaluation of lesional development and progression [published erratum appears in Arterioscler Thromb 1994 May:14(5):839]. Arterioscler Thromb. 1994;14:141-147.

39. Rosenfeld ME, Polinsky P, Virmani R, Kauser K, Rubanyi G, Schwartz SM. Advanced atherosclerotic lesions in the innominate artery of the ApoE knockout mouse. Arterioscler Thromb Vasc Biol. 2000;20:2587-2592.

40. Ross R. Rous-Whipple Award Lecture. Atherosclerosis: a defense mechanism gone awry. Am J Pathol. 1993;143:987-1002.

41. Ross R. Atherosclerosis-an inflammatory disease. N Engl J Med. 1999:340:115-126.

42. Rott D, Zhu J, Burnett MS, Zhou YF, Wasserman A, Walker J, Epstein SE. Serum of cytomegalovirus-infected mice induces monocyte chemoattractant protein-1 expression by endothelial cells. J Infect Dis. 2001;184:1109-1113.

43. Sandberg JK, Fast NM, Nixon DF. Functional heterogeneity of cytokines and cytolytic effector molecules in human CD8+ T lymphocytes. J Immunol. 2001;167:181-187.

44. Schmitz G, Herr AS, Rothe G. T-lymphocytes and monocytes in atherogenesis. Herz. 1998;23:168-177.

45. Smith PD, Saini SS, Raffeid M, Manischewitz JF, Wahi SM. Cytomegalovirus induction of tumor necrosis factor-alpha by human monocytes and mucosal macrophages. J Clin Invest. 1992; $90: 1642-1648$.

46. Soderberg-Naucler C. Fish KN, Nelson JA. Reactivation of latent human cytomegalovirus by allogeneic stimulation of blood cells from healthy donors. Cell. 1997;91:119-126.

47. Soderberg-Naucler C, Streblow DN, Fish KN, Allan-Yorke J, Smith PP, Nelson JA. Reactivation of latent human cytomegalovirus in $\mathrm{CD} 14(+)$ monocytes is differentiation dependent. J Virol. 2001;75:7543-7554.

48. Stary HC, Chandler AB, Dinsmore RE, Fuster V, Glagov S, Insull W, Jr., Rosenfeld ME, Schwartz CJ, Wagner WD, Wissler RW. A definition of advanced types of atherosclerotic lesions and a histological classification of atherosclerosis. A report from the Committee on Vascular Lesions of the Council on Arteriosclerosis, American Heart Association. Circulation. 1995;92:1355-1374.

49. Taylor-Wiedeman J, Sissons P, Sinclair J. Induction of endogenous human cytomegalovirus gene expression after differentiation of monocytes from healthy carriers. $J$ Virol. 1994;68:1597. 1604.

50. Vink C, Beuken E, Bruggeman CA. Complete DNA sequence of the rat cytomegalovirus genome. J Virol. 2000;74:7656-7665.

51. Vliegen I, Stassen F, Grauls G, Blok R, Bruggeman C. MCMV infection increases early Tlymphocyte influx in atherosclerotic lesions in apoE knockout mice. J Clin Virol. 2002;25 Suppl 2:159.

52. Whitman SC, Ravisankar $P$, Elam H, Daugherty A. Exogenous interferon-gamma enhances atherosclerosis in apolipoprotein E-/- mice. Am J Pathol. 2000;157:1819-1824.

53. Wick G. Perschinka H. Millonig G. Atherosclerosis as an autoimmune disease: an update. Trends Immunol. 2001;22:665-669.

54. Zhang SH, Reddick RL, Piedrahita JA, Maeda N. Spontaneous hypercholesterolemia and arterial lesions in mice lacking apolipoprotein E. Science. 1992;258:468-471. 
55. Zhou YF, Guetta E, Yu ZX, Finkel T, Epstein SE. Human cytomegalovirus increases modified low density lipoprotein uptake and scavenger receptor mRNA expression in vascular smooth muscle cells. J Clin Invest. 1996:98:2129-2138.

56. Zhou YF, Leon MB, Waclawiw MA, Popma JJ, Yu ZX, Finkel T, Epstein SE. Association between prior cytomegalovirus infection and the risk of restenosis after coronary atherectomy. N Engl J Med. 1996;335:624-630.

57. Zhou YF, Yu ZX, Wanishsawad C, Shou M, Epstein SE. The immediate early gene products of human cytomegalovirus increase vascular smooth muscle cell migration, proliferation, and expression of PDGF beta-receptor. Biochem Biophys Res Commun. 1999;256:608-613. 



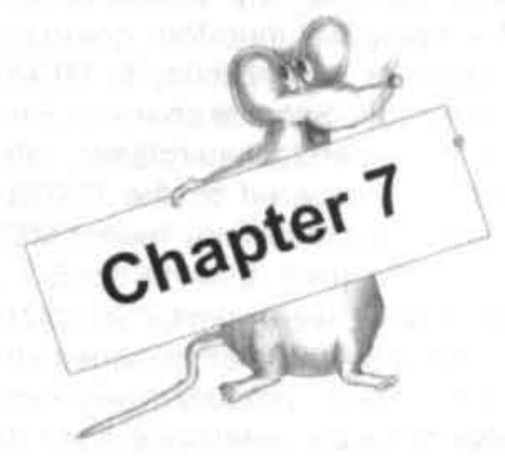

Increased basal immune activity renders hypercholesterolemic mice resistant to CMV infection

INGE VLIEGEN ${ }^{1}$, SELMA HERNGREEN ${ }^{1}$, GERT GRAULS ${ }^{1}$, ADRIAN DUIJVESTIJN ${ }^{2}$, CATHRIEN BRUGGEMAN ${ }^{1}$, FRANK STASSEN $^{1}$

Departments of Medical Microbiology ${ }^{1}$ and Immunology ${ }^{2}$, Cardiovascular Research Institute Maastricht (CARIM), University of Maastricht, the Netherlands 


\section{ABSTRACT}

Hypercholesterolemic mice $\left(\mathrm{apoE}^{-1}\right.$ and $\mathrm{LDLrec}^{-1}$ ), widely used to study the initiation and/or progression of atherosclerosis, are bred on a C57BL/6J background, which has been described as fairly resistant to mouse cytomegalovirus (MCMV). Recently it has been demonstrated that hypercholesterolemia may increase the susceptibility to bacterial and viral infections in mice. In this study we therefore compared C57BL/6J mice with apoE ${ }^{-1}$ and/or LDLrec ${ }^{-/ /}$mice for susceptibility to MCMV infection and for proinflammatory cytokine production. Survival characteristics after MCMV infection showed that both types of hypercholesterolemic mice were markedly less sensitive to MCMV infection compared to the C57BL/6J background strain. Real-time PCR analysis showed significantly higher MCMV DNA copy numbers in internal organs of $\mathrm{C} 57 \mathrm{BL} / 6 \mathrm{~J}$ mice than in apoE $\mathrm{E}^{-1-}$ mice. Although plasma cytokine levels (IFN $\gamma$ and TNF $\alpha$ ) were similar in $\mathrm{C} 57 \mathrm{BL} / 6 \mathrm{~J}$ and apoE ${ }^{-}$mice, cytokine production by isolated spleen macrophages strikingly differed between both mouse types. ApoE ${ }^{-1}$ mice produced significantly more IL-18 than C57BL/6J mice both under baseline conditions and following MCMV infection. Also IL-12 production by spleen macrophages was significantly increased in apoE ${ }^{-1}$ mice after LPS and MCMV infection when compared to C57BL/6J mice. These data suggest that, as a result of a higher activation status of the innate and as a consequence also adaptive immune response, hypercholesterolemic mice are less susceptible to MCMV than C57BL/6J. As LPS induced a different profile in cytokine production by spleen macrophages, this suggests that immune responses are MCMV specific. 


\section{INTRODUCTION}

Infections have been described to contribute to atherosclerosis ${ }^{33}$ and associations between both bacterial pathogens (Helicobacter pylori, Chlamydia pneumoniae) and viruses (cytomegalovirus (CMV)) and coronary heart disease have been reported ${ }^{5}$. To clarify the exact contribution of these pathogens to initiation and progression of atherosclerosis, appropriate animal models are needed. Although the mouse had generally been regarded as a species resistant to the development of atherosclerosis, the first evidence that mice could develop atherosclerotic lesions was actually demonstrated in 1968 by Vesselinovitch ${ }^{38}$. Later, Paigen described C57BL/6J to be the most atherosclerosis-susceptible inbred mouse strain ${ }^{24}$. Nonetheless, the application of gene targeting provided even better mouse models for atherosclerosis. Apolipoprotein $\mathrm{E}$ knockout $\left(a p o \mathrm{E}^{-l}\right.$ ) mice on a $\mathrm{C} 57 \mathrm{BL} / 6 \mathrm{~J}$ background spontaneously exhibit hypercholesterolemia and develop the full range of lesion pathology (from fatty streak to complex atherosclerotic lesions) similar as those seen in humans ${ }^{22,30}$. Low density lipoprotein receptor knockout (LDLrec ${ }^{-1}$ ) mice on a C57BL/6J background fail to develop atherosclerosis when fed a lowcholesterol diet but develop significant fatty streak lesions with a lipid-filled necrotic core throughout the aorta when fed an atherogenic diet ${ }^{15}$.

Although these knockout mice seem very promising animal models to study the contribution of infections to atherosclerosis, it is well known that the C57BL/6J strain is relatively resistant to mouse CMV (MCMV) infection ${ }^{1,34}$. On the other hand, hypercholesterolemia may render $\mathrm{apoE}^{-1}$ and $\mathrm{LDLrec}^{-1-}$ mice more susceptible to viral (i.e. Iymphocytic choriomeningitis virus) infections ${ }^{20}$. In addition hypercholesterolemic $\mathrm{apoE}^{-1}$ have been shown to be more susceptible for bacterial infections $\mathbf{s}^{6,7,32}$.

To investigate whether hypercholesterolemia also renders mice more susceptible to MCMV infection, survival characteristics after MCMV infection were determined in apoE $\mathrm{E}^{-t}$ and $\mathrm{LDLrec}^{-t-}$ mice with comparable plasma total cholesterol levels and compared with C57BL/6J mice. In addition, MCMV dissemination patterns were compared between both hyper- and normocholesterolemic C57BL/6J mice by real-time MCMV PCR in which the number of MCMV DNA copies per $\mu \mathrm{g}$ total DNA in different organs at various time points post infection was determined. Since LDLrec ${ }^{-1}$ showed similar survival characteristics as the apoE ${ }^{-1}$ mice, DNA copy numbers were exclusively quantified in $\mathrm{C} 57 \mathrm{BL} / 6 \mathrm{~J}$ and $a p o \mathrm{E}^{-1}$ mice. In an attempt to assess relevant immune mechanisms that may explain the differences in survival and MCMV dissemination observed between normo- and hypercholesterolemic mice, plasma IFN $\gamma$ and TNF $\alpha$ cytokine levels were measured and production of IL-18, IL-12, IL-10 and TNF $\alpha$ was measured in cultures of spleen macrophages from $\mathrm{apo} \mathrm{E}^{-1}$ and $\mathrm{C} 57 \mathrm{BL} / 6 \mathrm{~J}$ mice infected with MCMV.

\section{MATERIALS AND METHODS}

\section{Mice}

Forty-four 7-8-week-old specific pathogen-free (SPF) C57BL/6J and fortyfour 7-8-week-old SPF apoE $E^{+}$on a C57BL/6J background were purchased from 
Charles River, Someren, the Netherlands. In addition, six 4-week-old SPF LDLrec * on a C57BL/6J background were purchased from The Jackson Laboratory, Bar Harbor, ME, USA. C57BL/6J and apoE were fed ad libitum with standard chow diet and tap water. LDLrec ${ }^{*}$ mice had free access to tap water and were alternately put on purified diet W/ $0.15 \%$ cholesterol (Hope Farms, Woerden, the Netheriands) and normal chow diet to equalize plasma total cholesterol levels to apoE $E^{*}$ plasma total cholesterol levels. ApoE ${ }^{*}$ and LDLrec * plasma was collected after retro-orbital puncture and plasma total cholesterol levels were determined by Beckman Synchron CX Systems. Experiments were reviewed and approved by the Ethical Committee for the Use of Experimental Animals of the Maastricht University, and were conform the Guide for the Care and the Use of Laboratory Animals, published by the US National Institute of Health (NIH Publication No. 85-23, revised 1996).

\section{Infection protocol and tissue collection}

To determine MCMV sensitivity differences, eight apoE $\mathrm{E}^{-1}$ and $\mathrm{C57BL} / 6 \mathrm{~J}$ mice and six LDLrec ${ }^{-1}$ mice were intraperitoneally infected at 8 weeks of age with $5 \times 10^{5}$ PFU of salivary gland isolated mouse CMV (Smith strain) and mouse survival characteristics were determined up to 21 days post infection (p.i.).

In addition, twenty-four C57BL/6J and apoE $\mathrm{E}^{-}$were infected with $5 \times 10^{4}$ PFU of salivary gland isolated MCMV (Smith strain) and sacrificed at 1, 2, 4, 6, 14 or 28 days p.i. Prior to sacrifice the mice were anaesthetized with a weightadjusted dose of pentobarbital (Nembutal ${ }^{\infty}$, Sanofi Sante B.V., Maassluis, the Netherlands) and blood was collected by left ventricular puncture. Then the arterial tree was perfused at $100 \mathrm{mmHg}$ with sterile PBS via a catheter introduced into the left ventricular apex. Subsequently, salivary gland, lung, liver, spleen, the thoracic arterial tree (aortic arch, carotid arteries and thoracic aorta), heart and bone marrow cells were collected and stored at $-80^{\circ} \mathrm{C}$ for nucleic acid isolation. From whole EDTA-treated blood $100 \mu \mathrm{l}$ was added to 900 $\mu$ I NASBA buffer (Organon Teknika B.V., Boxtel, the Netherlands) and stored at $-80^{\circ} \mathrm{C}$ upon DNA isolation. The remaining blood was used to determine plasma IFN $\gamma$ and TNF $\alpha$ titers by ELISA.

Furthermore, twelve additional apoE $\mathrm{E}^{-*}$ and $\mathrm{C} 57 \mathrm{BL} / 6 \mathrm{~J}$ mice were sacrificed for spleen macrophages $(\mathrm{Sm} \varphi)$ isolation. IL-12, IL-18, IL-10 and TNF $\alpha$ production was determined in the culture medium of these $\operatorname{Sm} \varphi$ following MCMV-, LPS- or mock-stimulation.

\section{MCMV quantification by the standard MCMV PCR}

DNA was isolated from lung, liver, salivary gland, spleen, heart, aorta and bone marrow cells by using the Wizard genomic DNA purification kit (Promega Benelux B.V., Leiden, the Netherlands) according to the manufacturer's instructions. Isolations of nucleic acids from blood samples were carried out according to the method of Boom et al. ${ }^{3}$ MCMV-specific PCR was performed as described previously with slight modifications ${ }^{2}$. Briefly, one $\mu \mathrm{g}$ of the isolated DNA was subjected to PCR in a total volume of $50 \mu \mathrm{l}$. To check for the presence of PCR inhibitors, each sample was spiked with 10 copies of plasmid p189-p155. This plasmid contains nucleotides 180,551 to 180,913 of the MCMV 
Smith genome (Immediate early-1 (IE-1) exon 4, GenBank accession number U68299), which includes the primer sequences, and an additional fragment of 138 bp cloned into the MCMV sequence, corresponding to position 215,968 to 216,096 of the RCMV genomic sequence ${ }^{39}$. As a result of this insertion, the fragment generated by PCR from this control plasmid is 138 bp larger than the PCR fragment that is generated from MCMV genomic DNA ( 500 bp versus 362 bp). These fragments can be easily distinguished by agarose gel electrophoresis. The reaction mixture contained $0.2 \mu \mathrm{M}$ of each primer, $10 \mathrm{mM}$ Tris $\mathrm{HCl} \mathrm{pH} 8.5,50 \mathrm{mM} \mathrm{KCl}, 3.5 \mathrm{mM} \mathrm{MgCl}, 0.2 \mathrm{mM}$ dNTPs, 1.25 units of HotStarTaq DNA polymerase (Qiagen, Leusden, the Netherlands). The PCR was performed by an initial incubation at $95^{\circ} \mathrm{C}$ for $15 \mathrm{~min}$ to activate the HotStarTaq enzyme with 40 subsequent amplification cycles consisting of denaturation at $95^{\circ} \mathrm{C}$ for $30 \mathrm{~s}$, annealing at $58^{\circ} \mathrm{C}$ for $1 \mathrm{~min}$, and extension at $72^{\circ} \mathrm{C}$ for $1 \mathrm{~min}$. After the final cycle the extension step was prolonged with $5 \mathrm{~min}$ at $72^{\circ} \mathrm{C}$ and the temperature was subsequently lowered to $15^{\circ} \mathrm{C}$. Amplification products were separated on a $1.5 \%$ ethidium bromide-stained agarose gel. The sensitivity of the PCR technique was determined to be 1 copy of the p189-p155 plasmid.

\section{MCMV quantification by real-time PCR}

On all DNA samples positive for the standard MCMV PCR, we used the real-time PCR technique (ABI Prism 7000) to quantify the number of MCMV DNA copies per $\mu \mathrm{g}$ total DNA. Assays were prepared in 96 well Optical Reaction plates (Applied Biosystems, Foster City, California) in a total volume of $25 \mu \mathrm{l}$ containing the following components: $12.5 \mu \mathrm{l}$ of TaqMan universal master mix ( $2 x$ concentrated, Applied Biosystems), $300 \mathrm{nM}$ of forward primer, $300 \mathrm{nM}$ reverse primers, 200nM probe and $1 \mu \mathrm{g}$ DNA sample. Furthermore, when PCR inhibition was observed in the standard MCMV PCR technique, DNA samples were 10-fold diluted prior to application in the real-time PCR. Primers and probes for the detection of MCMV were based on the MCMV glycoprotein B sequence ( $\mathrm{gB}$, GenBank accession number M735191, forward primer 5'AGGGCTTGGAGAGGACCTACA-3', reverse primer 5'-GCCCGTCGGCAGTCT AGTC-3' and probe 5'-AGCTAGACGACAGCCAACGCAACGA-3'). The probe carried a 5' FAM reporter and a 3' TAMRA quencher group. Thermal cycling started with UNG activation for 2 min at $50^{\circ} \mathrm{C}$, followed by HotStarTaq activation during $10 \mathrm{~min}$ at $95^{\circ} \mathrm{C}$. Thereafter 42 cycles of amplification were run consisting of $15 \mathrm{~s}$ at $95^{\circ} \mathrm{C}$ and 1 minute at $60^{\circ} \mathrm{C}$. A negative control, containing reagents only, and serial dilutions of plasmid containing the MCMV gB sequence from position 930 to position 1348 were included in each run to generate a standard curve. The concentrations of the plasmid dilutions were: $10^{5}, 10^{4}, 10^{3}, 10^{2}, 10$ and 1 copy. The MCMV gB DNA concentration in the unknown samples was calculated by the ABI Prism 7000 SDS Software using the data from the standard curve.

\section{Macrophage culture}

Spleens were isolated from twelve apo $\mathrm{E}^{-\%}$ and twelve C57BL/6J mice (4 mice per type of stimulation) after anesthesia and perfusion with sterile PBS. Thereafter spleens were homogenized and cell suspensions were collected and washed twice at $1200 \mathrm{rpm}$ at $4^{\circ} \mathrm{C}$ for $10 \mathrm{~min}$ with macrophage serum free 
medium (MSFM, Gibco Invitrogen Corporation, Grand Island, New York). This medium prevents activation of macrophages in the presence of serum. Red blood cells were lysed with $\mathrm{NH}_{4} \mathrm{Cl}$ solution and spleen cells were washed twice with MSFM and finally resuspended in $1 \mathrm{ml}$ MSFM. $10^{6}$ spleen cells were plated out per well (48 well cell culture cluster, Costar, Cambridge, Massachusetts) followed by adherence of $\operatorname{Sm} \varphi$ to plastic during an incubation of 2 hours $\left(37^{\circ} \mathrm{C}\right.$, $5 \% \mathrm{CO}_{2}$ ). Cells were vigorously washed and non-adherent cells were removed and counted. Subtraction of the number of non-adherent cells from the original number of cells added to each well $\left(10^{6}\right)$ this reveals the actual numbers of cell adhering. As the number of adherent cells may not be constant between wells, the aforementioned provides us with a method to normalize ELISA data to the number of adherent macrophages. Tissue culture-passed, MSFM dissolved MCMV (Smith strain, $0.5 \mathrm{MOI}$ (multiplicity of infection)), LPS (Escherichia coli, serotype 055:B5, Sigma-Aldrich-Chemie GmbH, Steinheim, Germany; final concentration $1 \mu \mathrm{g} / \mathrm{ml}$ MSFM) or MSFM only was added to $\operatorname{Sm} \varphi$ containing wells. Then cells were centrifuged at $700 \mathrm{~g}$ for $45 \mathrm{~min}$ at $22^{\circ} \mathrm{C}$, washed and in the case of the LPS stimulation group, $1 \mu \mathrm{g} / \mathrm{ml}$ LPS was added de novo. Supernatants were collected at 1 and 2 days after incubation, centrifuged to discard cell debris and frozen at $-20^{\circ} \mathrm{C}$ till use. All experiments were performed in duplo. All solutions and buffers used for $\operatorname{Sm} \varphi$ isolation and culture were tested LPS-free by the LaL-assay (Limulus Ambocyte Lysate assay, Charles River Endosafe, Charleston, South Carolina).

\section{ELISA}

To study macrophage activation IL-10, IL-12, IL-18 and TNF $\alpha$ titers were determined in the culture medium of $\operatorname{Sm} \varphi$ at 1 and 2 days after MCMV infection, LPS stimulation or mock treatment. These cytokines were chosen for their antiviral activities (IL-18, IL-12, TNF $\alpha$ ) or for their involvement in viral escape (IL10). Plasma IFN $\gamma$ (also involved in antiviral immunity) and TNF $\alpha$ levels were scored as well. Cytokine levels were determined with commercially available ELISA kits, following the manufacturer's instructions; IL-12p40 and IL-18 (both from BD Pharmingen, San Diego, California) and IL-10, TNF $\alpha$ and IFN $\gamma$ (both from eBiosciences, San Diego, California). Concentrations under the lowest standard value were defined as zero i.e. under $15.6 \mathrm{pg} / \mathrm{ml}$ for IFN $\gamma$, TNF $\alpha$ and IL-12p40 and under $31.3 \mathrm{pg} / \mathrm{ml}$ for IL-10 and IL-18.

\section{Statistical analysis}

The Chi-Square test was used to test statistical differences in survival characteristics. Differences in MCMV DNA copy number/ $\mu \mathrm{g}$ total DNA between both $\mathrm{C} 57 \mathrm{BL} / 6 \mathrm{~J}$ and apoE $\mathrm{E}^{-}$mice were analyzed by the non-parametric MannWhitney $U$-test. To determine differences in cytokine production by $\operatorname{Sm} \varphi$ following different stimuli (LPS vs. MCMV vs. mock) the non-parametric Kruskall Wallis test was used. If a $P<0.05$ was obtained, the one-sided Mann-Whitney $U$ test was used to determine the difference in between 2 groups. In both in vivo as well as in vitro experiments differences in cytokine production between $\mathrm{C} 57 \mathrm{BL} / 6 \mathrm{~J}$ and apoE $\mathrm{E}^{-}$were analyzed with the Mann-Whitney U-test. Data are expressed as mean \pm S.E.M. and $P<0.05$ was considered statistically significant. 


\section{RESULTS}

\section{Survival characteristics}

$\mathrm{LDLrec}^{-1}$ mice were intermittently fed a high cholesterol diet or normal chow diet to ensure similar total plasma cholesterol levels as in apo $\mathrm{E}^{+}$mice during the entire experiment. At 8 weeks total plasma cholesterol levels were $10.67 \pm$ $0.52 \mathrm{mmol} / /\left(\mathrm{apoE}^{-1}\right), 9.98 \pm 0.94 \mathrm{mmol}^{\prime}\left(\right.$ LDLrec $\left.^{-1 /}\right)$ and $2.07 \pm 0.52 \mathrm{mmol} / \mathrm{l}$ (C57BL/6J). At 21 days p.i., levels were $13.6 \pm 0.59 \mathrm{mmol} / \mathrm{l}\left(\mathrm{apoE}^{-1 /}\right), 19.93 \pm$ $1.74 \mathrm{mmol} / / \mathrm{LDLrec}{ }^{-1}$ ) and $2.33 \pm 0.35 \mathrm{mmol} / \mathrm{l}(\mathrm{C} 57 \mathrm{BL} / 6 \mathrm{~J})$. Fig. 1 shows the survival characteristics of the different mouse types after infection with $5 \times 10^{5}$ PFU of MCMV. At 21 days p.i., all apoE ${ }^{-1}$ and LDLrec $^{-/}$mice were still alive, while only one out of eight C57BL/6J survived this infection dose $(P<0.05)$. This indicates higher MCMV susceptibility of the C57BL/6J mice when compared with the apoE ${ }^{-1}$ and LDLrec ${ }^{-1}$ mice.

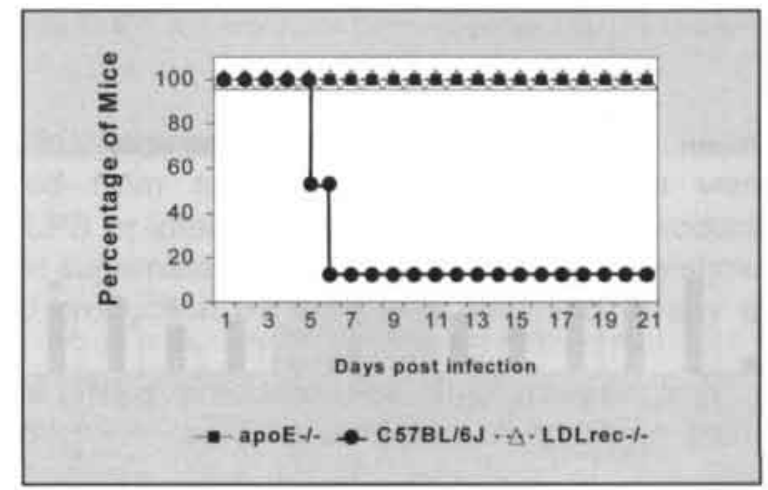

Fig. 1. Survival characteristics in normocholesterolemic C57BL/6J mice and hypercholesterolemic LDLrec ${ }^{+}$and apoE mice until day 21 after infection with $5 \times 10^{5}$ PFU MCMV. Data shown are expressed as percentage survival. $P<0.05$ when compared with the ChiSquare test. $A p o E^{\prime} /$ C57BL/6J mice; $n=8 /$ group, LDLrec mice: $n=6$.

\section{MCMV dissemination}

Because $\mathrm{LDLrec}^{-\alpha}$ and apoE $\mathrm{E}^{-1}$ mice showed similar survival characteristics after equal doses of MCMV, further experiments were limited to C57BL/6J and apoE $\mathrm{E}^{-1}$ mice. Although both mice types showed similar temporal MCMV distribution patterns (Fig. 2), the number of MCMV DNA copies/ $\mu \mathrm{g}$ total DNA was significantly higher in C57BL/6J mice in various organs at different time points p.i. compared with apoE $\mathrm{E}^{-1}$ mice. Maximum titers were seen in the liver of C57BL/6J mice at 4 days p.i. $(189,046 \pm 109,599$ copies MCMV DNA/ $\mu$ g total DNA) and apoE ${ }^{-1}$ at 2 days p.i. $(53,354 \pm 14,284$ copies MCMV DNA/ $\mu$ g total DNA). These data likewise suggest higher susceptibility of the C57BL/6J mice for MCMV. 

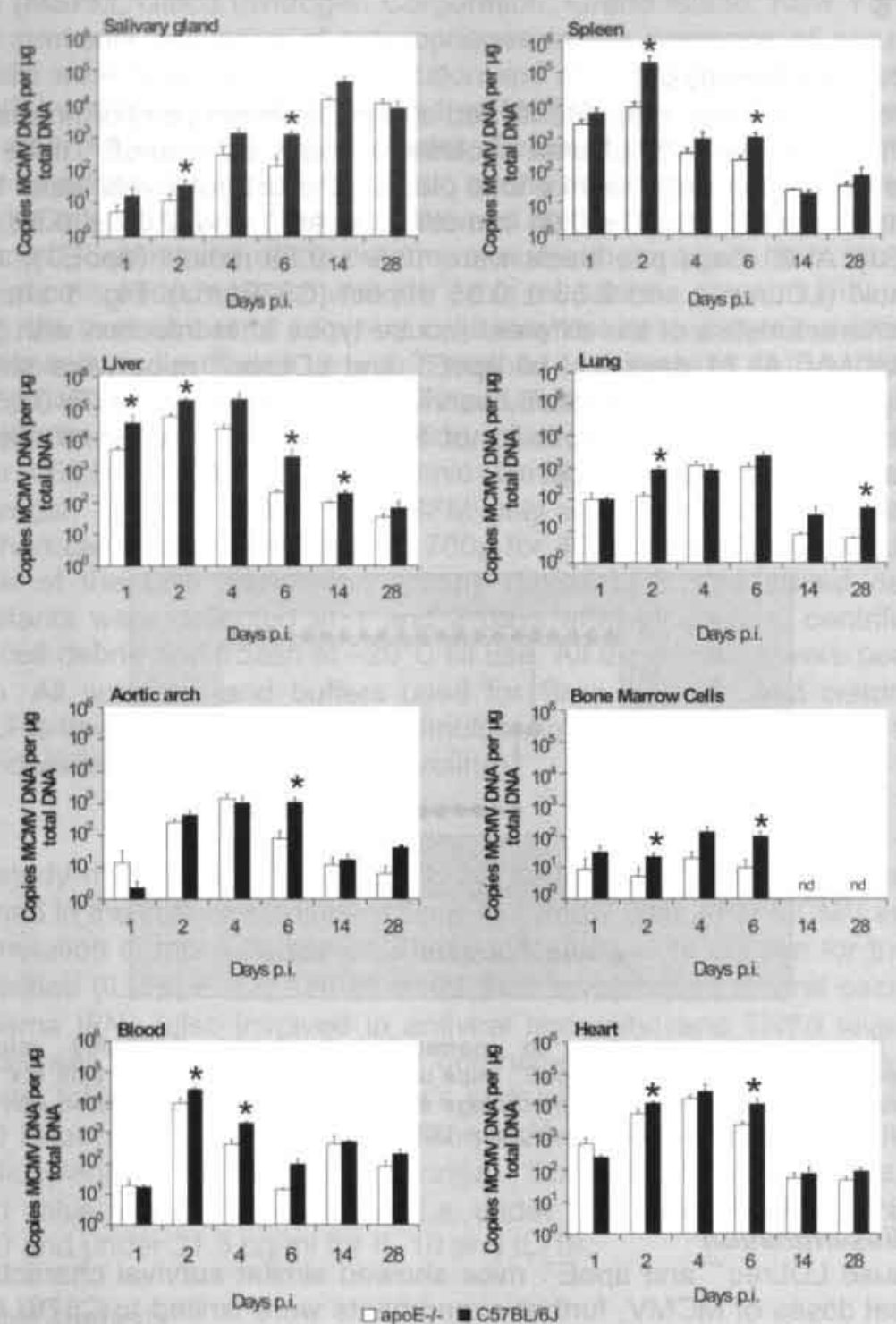

Fig. 2. MCMV dissemination in salivary gland, spleen, liver, lung, aortic arch, bone marrow, blood and heart from C57BL/6 J and apoE mice as determined by real-time MCMV PCR. Data are expressed mean \pm S.E.M. $\left(^{*}\right)$ Statistically significant difference between mouse types $(P<0.05)$. nd: not detected. $\mathrm{N}=4 /$ time point.

\section{Plasma cytokine levels in C57BL/6J and apoE $E^{\prime-}$ mice}

Plasma IFN $\gamma$ and TNF $\alpha$ levels were determined at 1, 2, 4 and 6 days p.i. to investigate whether differences in MCMV sensitivity between mouse types can be explained by differences in systemic immune activation (Fig. 3). IFN $\gamma$ titers 
peaked at 2 days p.i., while TNF $\alpha$ peaked at 4 days p.i. After this day, plasma cytokine levels declined to zero. Comparing plasma cytokine levels between $\mathrm{C} 57 \mathrm{BL} / 6 \mathrm{~J}$ and apoE $\mathrm{E}^{-}$mice revealed no differences between both mouse types.

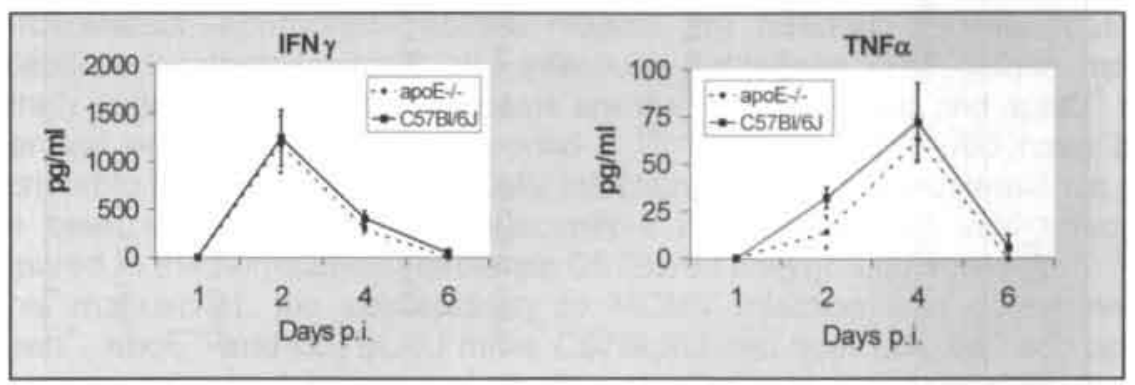

Fig. 3. Plasma IFN $\gamma$ and TNF $\alpha$ levels in C57BL/6J and apoE mice at 1, 2, 4 and 6 days p.i. Data are determined by ELISA and expressed as mean levels \pm S.E.M. N $=4$ mice per time point.

\section{Macrophage cytokine production after stimulation}

$\operatorname{Sm} \varphi$ isolated from $a \mathrm{poE}^{-/}$and $\mathrm{C} 57 \mathrm{BL} / 6 \mathrm{~J}$ mice were mock-treated, stimulated with LPS or infected with MCMV. Cytokine production by $\operatorname{Sm} \varphi$ was determined in the supernatant 1 and 2 days post infection/stimulation (Table 1).

IL-10: no IL-10 production by $\operatorname{Sm} \varphi$ was observed at any time point in any group.

TNF $\alpha$ : no basal TNF $\alpha$ production by $\operatorname{Sm} \varphi$ isolated from either apoE ${ }^{-1}$ or C57BL/6J mice could be detected at any time point. Similar results were observed after MCMV infection of the $\operatorname{Sm} \varphi$. Nonetheless, stimulation with LPS resulted in a marked increase in TNF $\alpha$ production in apoE $E^{-1 /}$ mice

IL-12: as with TNF $\alpha$, near background levels of IL-12 could be detected under baseline conditions. However, when $\operatorname{Sm} \varphi$ were MCMV-infected a marked increase in $\mathrm{IL}-12$ production by $\mathrm{Sm} \varphi$ from both $\operatorname{apoE}^{-1}$ and C57BL/6J mice was observed. Furthermore, IL-12 production by MCMV- infected apoE ${ }^{-1-} \operatorname{Sm} \varphi$ was significantly higher than the IL-12 production by MCMV-infected C57BL/6J Sm $\varphi$ at 2 p.i. LPS stimulation also stimulated the production of IL-12. This stimulation was more pronounced in apoE ${ }^{-1-} \mathrm{S} m \varphi$ than in C57BL/6J $\mathrm{Sm} \varphi$.

IL-18: no basal IL-18 production by C57BL/6J Sm $\varphi$ was observed. In contrast, apo: ${ }^{-1} \operatorname{Sm} \varphi$ already displayed a marked IL-18 production even under baseline conditions. While, MCMV infection increased IL-18 production in both $\operatorname{apoE}^{-1} \operatorname{Sm} \varphi$ and $\mathrm{C} 57 \mathrm{BL} / 6 \mathrm{~J} \operatorname{Sm} \varphi$, the production was significantly more augmented in $\operatorname{apoE}^{*} \mathrm{Sm} \varphi$ compared to C57BL/6J $\operatorname{Sm} \varphi$. LPS stimulation did not have a significant effect on IL-18 production in either type of $\operatorname{Sm} \varphi$. 
Table 1. Cytokine expression profiles of mock treated, LPS-stimulated and MCMV-infected Sm $\varphi$.

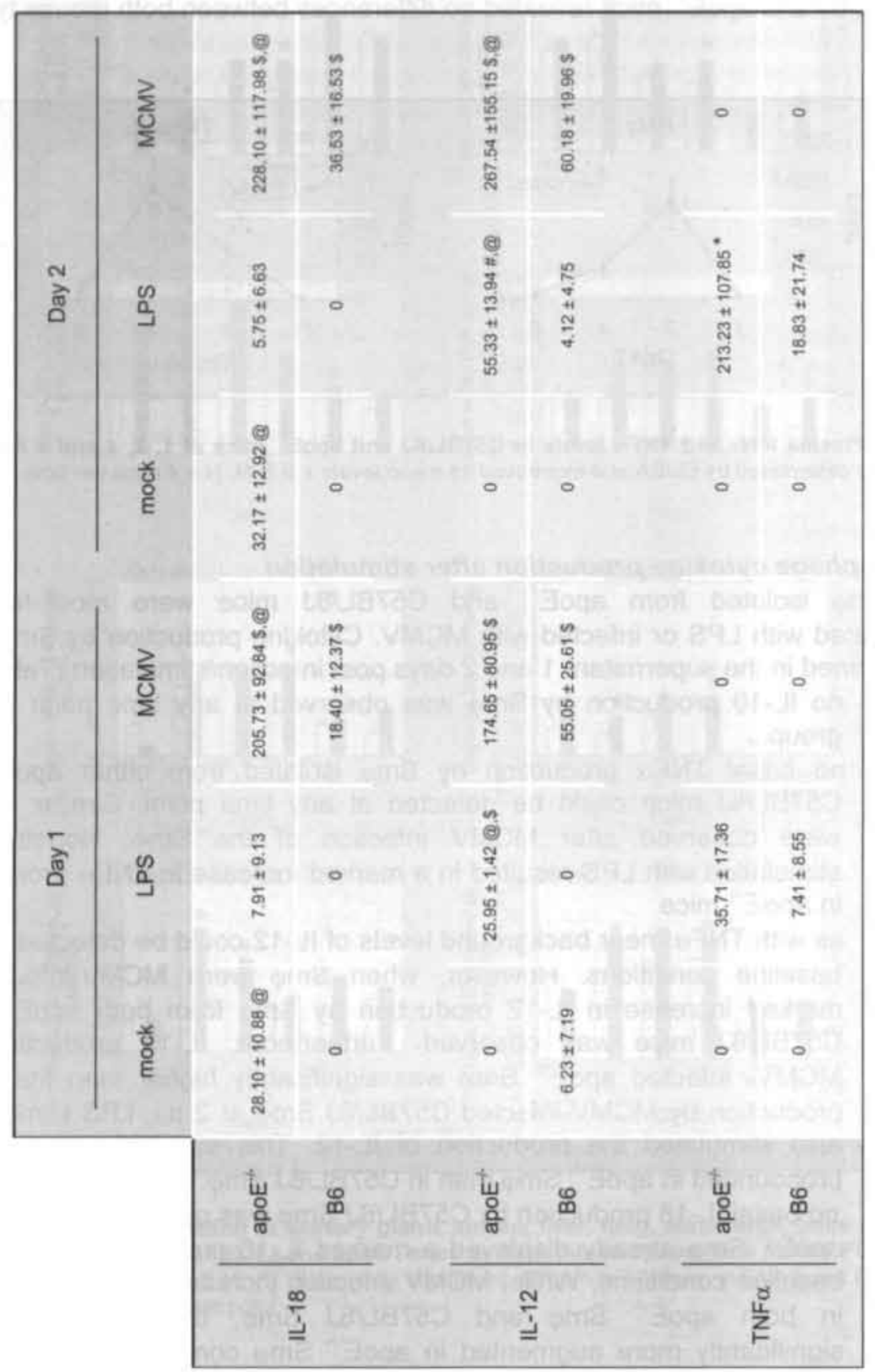

(@): $P<0.05$ : apoE versus B6; (\#): $P<0.05$ : LPS versus mock; ( $\$$ ): $P<0.05$ : $M C M V$ versus mock and LPS; ("): P<0.05: LPS versus mock and MCMV. B6 $=$ C57BI/ $6 \mathrm{~J} . \mathrm{N}=4$ mice, measured in duplo. Data are expressed as mean \pm S.E.M. 


\section{DISCUSSION}

Infectious agents, including CMV, are now currently being considered to play a role in the initiation and progression of atherosclerosis ${ }^{11,12,21}$. To study the underlying mechanisms involved in the contribution of infections to atherosclerosis, appropriate animal models are needed: animals must be susceptible to atherosclerosis and infectious pathogens. The mouse models routinely used to study atherosclerosis are the $\mathrm{LDLrec}^{-1}$ mice and apoE $\mathrm{F}^{-1}$ mice generated on a C57BL/6 J background ${ }^{4} .29,36$. While C57BL/6J have been described to be fairly resistant to CMV infection ${ }^{1,34}$, hypercholesterolemic mice have been shown to be more susceptible to bacterial and viral infections compared to the normocholesterolemic C57BL/6J background strain ${ }^{6,7,20,32}$.

In this manuscript, the susceptibility to MCMV infection was determined in

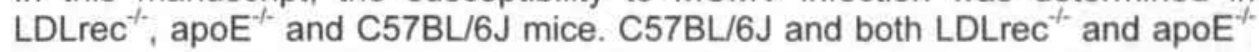
mice were subjected to survival studies to eliminate the possibility that an altered susceptibility to MCMV could be attributed to one of the knocked-out genes. To normalize hypercholesterolemic group comparison, total plasma cholesterol levels in LDLrec $^{-t}$ mice were titrated to levels observed in apo $E^{-1-}$ mice. Nevertheless, in contrast to previous findings for bacterial and viral infections ${ }^{6,7,32}$, both types of hypercholesterolemic mice showed a lower susceptibility to MCMV than C57BL/6J, reflected by the death of all but one in the C57BL/6J group compared with $100 \%$ survival in both hypercholesterolemic groups. Since $\mathrm{LDLrec}^{-1 /}$ and apoE $\mathrm{E}^{-1}$ mice showed similar survival characteristics, this implicates that specifically knocking out one of these genes is not responsible for the observed differences with the C57BL/6J background strain. Therefore, further experiments in this manuscript were limited to apo: ${ }^{-1}$ and C57BL/6J mice. In addition to survival characteristics, organ specific MCMV DNA copy number/ug total DNA was determined in apo: $\mathrm{E}^{\prime-}$ and $\mathrm{C} 57 \mathrm{BL} / 6 \mathrm{~J}$. To determine copy number, the real-time PCR technique was chosen instead of the plaque assay, since the PCR technique shows higher sensitivity for MCMV presence than the latter technique ${ }^{40}$. Significant higher DNA copy numbers were observed in salivary glands, spleens, livers, lungs, aortic arches, bone marrow cells, blood and hearts from C57BL/6J mice when compared with apoE $E^{-1}$ mice, despite similar dissemination patterns. These data support the above-mentioned observation that hypercholesterolemic mice are less susceptible to MCMV infection than C57BL/6J mice.

As IFN $\gamma^{8,26,27}$ and TNF $\alpha^{14,19}$ have been reported to protect against CMV infection, levels of both cytokines were determined in plasma of both apoE $\mathrm{E}^{-/}$and C57BL/6 J mice at various time points post infection in an attempt to clarify the observed susceptibility differences. Similar temporal patterns were seen in both apo $\mathrm{E}^{-\alpha}$ and $\mathrm{C} 57 \mathrm{BL} / 6 \mathrm{~J}$ and no differences were observed in the levels of IFN $\gamma$ and TNF $\alpha$ between both mouse types. These data show that differences in susceptibility are not a result of different systemic levels of IFN $\gamma$ and TNF $\alpha$.

As macrophages have been described to be important in the first line of defense against MCMV infection ${ }^{13,16,18.28,37}$, we assessed the effect of MCMV infection on cytokine production by isolated $\operatorname{Sm} \varphi$. At 1 and 2 days after infection or mock treatment, IL-10, IL-12, IL-18 and TNF $\alpha$ production by $\operatorname{Sm} \varphi$ was determined. IL-10 was selected because murine CMV has been described to 
interfere with the MHC class II antigen-presentation pathway from macrophages by utilizing IL-10, thereby potentially influencing MCMV susceptibility. CMV can either make use of a viral homolog of IL-10 (cmvIL-10) ${ }^{17}$ or stimulate the release of cellular IL-10 from macrophages ${ }^{31}$. However, no IL-10 production by $\operatorname{Sm} \varphi$ was observed at any time point p.i. IL-12 has been reported to be responsible for early NK cell IFN $\gamma$ production and viral control ${ }^{23}$ and IL-18 is a recently discovered pro-inflammatory cytokine with functional similarities to IL$12^{9}$. Although the importance of IL-18 in immunity and host defense is only beginning to be appreciated, Pien et al. described IL-18 to be required for systemic and splenic responses against $\mathrm{CMV}{ }^{25}$. As expected, MCMV infection increased IL-18 and IL-12 production by $\operatorname{Sm} \varphi$ derived from both apoE $\mathrm{E}^{-/}$and C57BL/6J mice. However, IL-18 and IL-12 production was significantly higher in the cultures from apoE ${ }^{*} \operatorname{Sm} \varphi$ when compared to C57BL/6J Sm $\varphi$ cultures. Furthermore, IL-18 was already produced by $\operatorname{apoE}^{-1} \operatorname{Sm} \varphi$ under basal conditions while no IL-18 could be detected in the supernatant from C57BL/6J $\operatorname{Sm} \varphi$ under these conditions. These data suggest that (i) $\operatorname{Sm} \varphi$ of apo $\mathrm{E}^{-/}$have a higher baseline activation status than those of C57BL/6J and (ii) Sm $\varphi$ cytokine production following MCMV infection is more pronounced in $\operatorname{apoE}^{-1} \operatorname{Sm} \varphi$. These findings may partially explain why $\mathrm{apoE}^{-/}$mice are less susceptible to $\mathrm{MCMV}$ infection than C57BL/6J mice.

To analyze whether the observed differences in cytokine production by $\operatorname{Sm} \varphi$ are specific for MCMV-mediated immune activation, cytokine levels in the supernatants of LPS-stimulated $\operatorname{Sm} \varphi$ were studied and compared with both MCMV- and mock-treated groups. LPS significantly stimulated the production of IL-12 by apoE ${ }^{-1} \mathrm{Sm} \varphi$ significantly above baseline. This enhancement was not observed in C57BL/6J Sm $\varphi$. However, elevations in IL-12 production by LPSstimulation of apoE $E^{-1} \operatorname{Sm} \varphi$ was lower than that measured from MCMV-infected apoE ${ }^{+} \mathrm{Sm} \varphi$. LPS-induced IL-18 production was absent in C57BL/6J mice or low in $\mathrm{apoE}^{-1}$ mice. Furthermore, LPS-induced IL-18 production was comparable with the observed production after mock treatment. As LPS has been regularly described and used as a potent inducer of TNF $\alpha$ production ${ }^{10.35}$, it was not surprising to observe fair TNF $\alpha$ production by all LPS-treated $\operatorname{Sm} \varphi$ samples. Although the $\mathrm{TNF} \alpha$ production was significantly enhanced in apoE $\operatorname{Sm} \varphi$ at 2 days post stimulation when compared with MCMV- and mock-treated macrophages, no major differences were observed in TNF $\alpha$ production between apoE ${ }^{-1}$ and C57BL/6J Sm $\varphi$. As cytokine production profiles by LPS-stimulated $\operatorname{Sm} \varphi$ were generally different from profiles detected in $\operatorname{Sm} \varphi$ following MCMV infection, this suggests immune responses directed against MCMV to be specific.

Summarizing, our data suggest that the innate immune system in hypercholesterolemic mice is more reactive than in normocholesterolemic mice. This increased innate immune system reactivity allows an acute response to virus, thereby diminishing viral dissemination. Furthermore, since IL-12 and IL18 are relevant in triggering the adaptive immune response, in particular T helper 1 responses ${ }^{9.4}$, it may be that also the adaptive immune system reacts more adequate in hypercholesterolemic mice. As such this will contribute to effective MCMV-specific immune responses and reduced mortality after MCMV 
infection in hypercholesterolemic mice. However, future experiments are required to define the precise immune status of these mice. Interestingly, since hyper-cholesterolemic mice suffer from atherosclerosis ${ }^{15,22}$, which is currently considered as an immune-mediated disease, it may be speculated that the increased immune status in these mice not only contributes to the development of severe atherosclerotic plaques but also protects mice from infections. Nonetheless, evidence against this hypothesis comes from previous reports demonstrating that these mice are more susceptible for other infections than MCMV ${ }^{6,20}$. Therefore, further experiments are needed to elucidate if MCMV infection is the only exception in this respect.

\section{ACKNOWLEDGEMENTS}

The authors would like to thank Sabine Stevens for technical support and Mohamed Hadfoune for performing the LaL assay.

\section{REFERENCES}

1. Allan JE, Shellam GR. Genetic control of murine cytomegalovirus infection: virus titres in resistant and susceptible strains of mice. Arch Virol. 1984;81:139-150.

2. Balthesen $M$, Messerle $M$, Reddehase MJ. Lungs are a major organ site of cytomegalovirus latency and recurrence. $J$ Virol. 1993;67:5360-5366.

3. Boom R, Sol CJ. Salimans MM, Jansen CL, Wertheim-van Dillen PM, van der Noordaa J. Rapid and simple method for purification of nucleic acids. J Clin Microbiol. 1990;28:495-503.

4. Breslow JL. Mouse models of atherosclerosis. Science. 1996;272:685-688.

5. Danesh J, Collins R, Peto R. Chronic infections and coronary heart disease: is there a link? [see comments]. Lancet. 1997;350:430-436.

6. de Bont N, Netea MG, Demacker PN, Verschueren I, Kullberg BJ, van Dijk KW, van der Meer JW, Stalenhoef AF. Apolipoprotein E knock-out mice are highly susceptible to endotoxemia and Klebsiella pneumoniae infection. J Lipid Res. 1999;40:680-685.

7. de Bont N. Netea MG, Demacker PN, Kullberg BJ, van der Meer JW, Stalenhoef AF Apolipoprotein E-deficient mice have an impaired immune response to Klebsiella pneumoniae. Eur J Clin Invest. 2000;30:818-822.

8. Delannoy AS, Hober D, Bouzidi A, Wattre P. Role of interferon alpha (IFN-alpha) and interferon gamma (IFN-gamma) in the control of the infection of monocyte-like cells with human cytomegalovirus (HCMV). Microbiol Immunol. 1999;43:1087-1096.

9. Dinarello CA. Interleukin-18. Methods. 1999;19:121-132.

10. Drouet $\mathrm{C}$, Shakhov AN. Jongeneel CV. Enhancers and transcription factors controlling the inducibility of the tumor necrosis factor-alpha promoter in primary macrophages. $J$ Immunol. 1991:147:1694-1700.

11. Ellis RW. Infection and coronary heart disease. J Med Microbiol. 1997:46:535-539.

12. Gupta $\mathrm{S}$, Camm AJ. Is there an infective aetiology to atherosclerosis? Drugs and aging. 1998:13:1-7.

13. Hamano $S$, Yoshida $H$, Takimoto $H$, Sonoda $K$, Osada $K$, He X, Minamishima $Y$, Kimura G. Nomoto K. Role of macrophages in acute murine cytomegalovirus infection. Microbiol Immunol. 1998:42:607-616.

14. Heise MT, Virgin HWt. The T-cell-independent role of gamma interferon and tumor necrosis factor alpha in macrophage activation during murine cytomegalovirus and herpes simplex virus infections. J Virol. 1995;69:904-909.

15. Ishibashi S, Goldstein JL, Brown MS, Herz J, Burns DK. Massive xanthomatosis and atherosclerosis in cholesterol-fed low density lipoprotein receptor-negative mice. J Clin Invest. 1994:93:1885-1893.

16. Iwamoto GK, Monick MM, Clark BD, Auron PE, Stinski MF, Hunninghake GW. Modulation of interleukin 1 beta gene expression by the immediate early genes of human cytomegalovirus. $J$ Clin Invest. 1990;85:1853-1857. 
17. Kotenko SV, Saccani S, Izotova LS, Mirochnitchenko OV, Pestka S. Human cytomegalovirus harbors its own unique IL-10 homolog (cmvIL-10). Proc Natl Acad Sci USA. 2000;97:16951700.

18. Le Roy E, Baron M, Faigle W, Clement D, Lewinsohn DM, Streblow DN, Nelson JA, Amigorena S, Davignon JL. Infection of APC by human cytomegalovirus controlled through recognition of endogenous nuclear immediate early protein 1 by specific $\operatorname{CD} 4(+) T$ lymphocytes. J Immunol. 2002;169:1293-1301.

19. Lucin P, Jonjic S, Messerle M, Polic B, Hengel H, Koszinowski UH. Late phase inhibition of murine cytomegalovirus replication by synergistic action of interferon-gamma and tumour necrosis factor. J Gen Virol. 1994:75:101-110.

20. Ludewig B, Jaggi M, Dumrese T, Brduscha-Riem K, Odermatt B, Hengartner H, Zinkernagel RM. Hypercholesterolemia exacerbates virus-induced immunopathologic liver disease via suppression of antiviral cytotoxic T cell responses. J Immunol, 2001:166:3369-3376.

21. Mattila KJ, Valtonen VV. Nieminen MS, Asikainen S. Role of infection as a risk factor for atherosclerosis, myocardial infarction, and stroke. Clin Infect Dis. 1998;26:719-734.

22. Nakashima Y. Plump AS, Raines EW, Breslow JL, Ross R. ApoE-deficient mice develop lesions of all phases of atherosclerosis throughout the arterial tree. Arterioscler Thromb. 1994:14:133-140.

23. Orange JS, Biron CA. An absolute and restricted requirement for IL-12 in natural killer cell IFNgamma production and antiviral defense. Studies of natural killer and $T$ cell responses in contrasting viral infections. J Immunol. 1996;156:1138-1142.

24. Paigen B, Morrow A, Brandon C, Mitchell D. Holmes P. Variation in susceptibility to atherosclerosis among inbred strains of mice. Atherosclerosis. 1985;57:65-73.

25. Pien GC, Satoskar AR, Takeda K, Akira S, Biron CA. Cutting edge: selective IL-18 requirements for induction of compartmental IFN-gamma responses during viral infection. $J$ Immunol. 2000;165:4787-4791.

26. Pomeroy C, Delong D, Clabots C, Riciputi P, Filice GA. Role of interferon-gamma in murine cytomegalovirus infection. J Lab Clin Med. 1998:132:124-133.

27. Presti RM, Pollock JL, DalCanto AJ, AK OG, Virgin HW. Interferon gamma regulates acute and latent murine cytomegalovirus infection and chronic disease of the great vessels. $J$ Exp Med. 1998;188:577-588.

28. Pulliam L, Moore D, West DC. Human cytomegalovirus induces IL-6 and TNF alpha from macrophages and microglial cells: possible role in neurotoxicity. J Neurovirol. 1995;1:219-227.

29. Reardon CA, Getz GS. Mouse models of atherosclerosis. Curr Opin Lipidol. 2001;12:167-173.

30. Reddick RL, Zhang SH, Maeda N. Atherosclerosis in mice lacking apo E. Evaluation of lesional development and progression [published erratum appears in Arterioscler Thromb 1994 May:14(5):839]. Arterioscler Thromb. 1994:14:141-147.

31. Redpath S, Angulo A, Gascoigne NR, Ghazal P. Murine cytomegalovirus infection downregulates MHC class II expression on macrophages by induction of IL-10. J Immunol. 1999;162:6701-6707.

32. Roselaar SE, Daugherty A. Apolipoprotein E-deficient mice have impaired innate immune responses to Listeria monocytogenes in vivo. J Lipid Res. 1998:39:1740-1743.

33. Ross R. Atherosclerosis-an inflammatory disease. N Engl J Med. 1999;340:115-126.

34. Scalzo AA, Fitzgerald NA, Wallace CR, Gibbons AE, Smart YC, Burton RC, Shellam GR. The effect of the Cmv-1 resistance gene, which is linked to the natural killer cell gene complex, is mediated by natural killer cells. J Immunol. 1992;149:581-589.

35. Shakhov AN, Collart MA, Vassalli P. Nedospasov SA, Jongeneel CV. Kappa B-type enhancers are involved in lipopolysaccharide-mediated transcriptional activation of the tumor necrosis factor alpha gene in primary macrophages. J Exp Med. 1990;171:35-47.

36. Smith JD, Breslow JL. The emergence of mouse models of atherosclerosis and their relevance to clinical research. J Intern Med. 1997;242:99-109.

37. Smith PD, Saini SS, Raffeld M. Manischewitz JF, Wahl SM. Cytomegalovirus induction of tumor necrosis factor-alpha by human monocytes and mucosal macrophages. J Clin Invest. 1992:90:1642-1648.

38. Vesselinovitch D. Wissler RW. Experimental production of atherosclerosis in mice. 2. Effects of atherogenic and high-fat diets on vascular changes in chronically and acutely irradiated mice. $J$ Atheroscler Res. 1968;8:497-523.

39. Vink C, Beuken E, Bruggeman CA. Complete DNA sequence of the rat cytomegalovirus genome. J Virol. 2000:74:7656-7665.

40. Vliegen I, Herngreen S, Grauls G, Bruggeman C. Stassen F. Improved detection and quantification of mouse cytomegalovirus by real-time PCR. Virus res. in press. 
41. Watford WT, Moriguchi M. Morinobu A, O'Shea JJ. The biology of IL-12; coordinating innate and adaptive immune responses. Cytokine Growth Factor Rev. 2003;14:361-368. 

chapter

8

General Discussion and Summary 
In the late 1970 's, Fabricant et al. ${ }^{14}$ discovered that infections with an avian herpesvirus resulted in atherosclerosis-like phenomena in various arteries of chickens. The aforementioned study was the first to suggest a role for infections in atherosclerosis. Since then, evidence which supports infection as an additional risk factor for cardiovascular diseases has been accumulating. Multiple pathogens have been associated with coronary and peripheral artery disease and myocardial infarction ${ }^{11}, 30,32$. Best characterized is the role of Chlamydia pneumoniae, an obligate intracellular gram-negative bacterium, in cardiovascular disease ${ }^{17,22,42}$. Cytomegalovirus (CMV), a member of the $\beta$ herpesvirus family, has also been associated with various vascular disorders such as restenosis ${ }^{12,46}$ and transplantation-associated arteriosclerosis ${ }^{2,4,24,26}$. Moreover, sero-epidemiological as well as in vitro data and a limited number of experimental in vivo studies suggest an association between CMV and atherosclerosis $3,13,40$. The studies published to date do not however unambiguously certify that CMV affects the atherosclerotic process. Furthermore, the mechanisms by which CMV contribute to atherosclerosis have yet to be elucidated. In this thesis we have addressed these aspects in various in vivo and in vitro studies. The results of these studies will be discussed in the following paragraphs.

\section{CONTRIBUTES TO ATHEROSCLEROSIS}

As CMV infections are very common in normal human populations, finding a control group for an epidemiological study is quite difficult. Ethical considerations make clinical epidemiological research examining the contribution of $\mathrm{CMV}$ to atherosclerosis and the underlying mechanisms impossible. To overcome these problems we used a common animal model for atherosclerosis. The preferred experimental model for studying atherogenesis is the apo $\mathrm{E}^{\prime}$ mouse ${ }^{33,56}$, which is characterized by the spontaneous development of atherosclerotic lesions in the arterial tree similar to human atherosclerosis. Previous studies already demonstrated that the mouse variant of human CMV (mouse CMV, MCMV) increased the total atherosclerotic lesion area in the aortic root of these apoE ${ }^{-1}$ mice ${ }^{5,25}$. However, in these studies mice were infected at the age of 2 weeks. Due to the immaturity of the mouse immune system at this age, anti-viral immune responses are inefficient and consequently viral pathogenesis may be more pronounced. Therefore, data from the aforementioned study may only reflect the effect of CMV infection on atherosclerosis in immuno-compromised patients. When Rott et al. infected immune-mature young adult mice at 8 weeks of age and sacrificed those 3 weeks after no effect of MCMV infections on atherosclerosis could be demonstrated ${ }^{41}$ suggesting that CMV-mediated aggravation of atherosclerosis is restricted to immuno-compromised patients. Alternatively, the three week infection period may have been too short for MCMV to noticeably affect the atherosclerotic process. To evaluate the time frame needed for MCMV to affect atherosclerosis, we infected 8-week-old $\mathrm{apoE}^{-1}$ mice and determined the number and mean area of the atherosclerotic lesions in the aortic arch as well as the severity of the lesions (according to the American Heart Association classification) at 2 and 20 weeks post infection (chapter 2). In accordance with 
the data presented by Rott et al. we didn't observe any statistically significant difference between MCMV- and mock-infected mice with respect to lesion area, number of lesions or severity of atherosclerosis at 2 weeks post infection. Yet, at 20 weeks post infection, lesion area was significantly increased in the MCMV-infected group. Therefore, these data i) suggest that CMV is able to aggravate atherosclerosis in the immune-competent host and ii) demonstrate the applicability of the apoE mouse model to study the fundamental mechanisms by which CMV has an impact on the atherosclerotic process.

\section{MECHANISMS BY WHICH MCMV AFFECTS ATHEROSCLEROSIS}

\section{Indirect effects based on the systemic production of pro-atherogenic cytokines}

Cytokines play a prominent role in atherosclerotic disease progression. A number of cytokines have been shown to be present in atherosclerotic lesions and to be able to modulate plaque development ${ }^{23}$. Furthermore, increased systemic cytokine levels have also been shown to augment atherosclerosis in apoE $E^{-/}$mice ${ }^{53,54}$. In these mice a marked augmentation in lesion size was observed following repeated IFN $\gamma$ or IL-18 injections suggesting a prominent role for these cytokines in disease progression.

IL-18 is a recently discovered cytokine with functional similarities to IL-12. It was originally described as a Kupffer cell-derived co-stimulating factor essential for the production of IFN $\gamma$ in a murine LPS-induced shock model ${ }^{34}$. Since then it has been shown that a variety of cell types, such as keratinocytes, osteoblasts and adrenal cortex cells, are able to synthesize this protein ${ }^{6,47.48}$. Furthermore, viral infections (influenza A virus, Sendai virus) have been shown to induce to production of IL- 18 by isolated human macrophages ${ }^{37}$. In accordance with the data mentioned above, a small but significant increase in $\mathrm{IL}-18$ production was seen when we infected spleen macrophages isolated from C57BL/6J mice in vitro (chapter 7). In spleen macrophages isolated from hypercholesterolemic apoE mice, however, marked production of IL-18 was already seen under baseline conditions and this IL-18 production was increased almost 10 -fold following MCMV infection. Also, IL-12 production by isolated spleen macrophages was significantly more pronounced in $\mathrm{apoE}^{-l}$ mice following MCMV infection. Similar results were obtained when we evaluated cytokine production by peritoneal macrophages 7 days post intraperitoneal MCMV injection in apoE ${ }^{-1}$ mice (chapter 5). Peritoneal macrophages isolated from MCMV-infected mice produced IL-18 in contrast to macrophages isolated from thioglycolate-challenged mice. Furthermore, a significant increase in IFNy production by peritoneal macrophages isolated from MCMV-infected mice was observed which most likely results from autocrine macrophage activation mediated by the synergistic effect of $\mathrm{IL}-18$ and $\mathrm{IL}-12^{31}$.

Primarily, the production of these cytokines may represent key events during innate immune reactions. Both IL-12 and IL-18 have been implicated in the early response to infections ${ }^{9,52}, \mathrm{IL}-12$ induces NK cells to rapidly secrete IFN $\gamma$. Furthermore, IL-12 stimulates IFN $\gamma$ production by T cells and is the key cytokine driving Th 1 differentiation. IL-18 shares many functional similarities 
with IL-12. Furthermore, strong synergistic effects between IL-12 and IL-18 have been described in the induction of IFN $\gamma$ secretion by T cells, NK cells or macrophages. At his turn, IFN $\gamma$ regulates $\mathrm{CMV}$ infection, inhibits reactivation from latency and inhibits CMV IE gene expression ${ }^{18,38,}{ }^{39}$. Interestingly, we observed a marked increase in the capacity of spleen macrophages from apoE mice to secrete IL-12 and IL-18 compared to C57BL/6J macrophages (chapter 7). This finding suggests that apoE mice are more competent in producing IFN $\gamma$ and may partially explain the difference in sensitivity for MCMV infections between these 2 mouse types. On the other hand, recent data suggest that oxLDL is able to stimulate the production of IL-12 and subsequently IFN $\gamma$ by peripheral blood mononuclear cells ${ }^{15}$, suggesting that hypercholesterolemia protects against CMV infections by activating the immune system.

\section{Implications for atherosclerosis}

In chapter 5 and 7 we demonstrated that peritoneal and spleen macrophages isolated from apo $\mathrm{E}^{-}$mice are able to secrete significant amounts of IL-12, IL-18 and IFN $\gamma$ in response to MCMV infection. Interestingly, all three cytokines have been implicated in the progression of atherosclerosis. Repeated injections with recombinant IL-18 significantly increased aortic lesion size in $\mathrm{apo} \mathrm{E}^{-/}$mice and this effect was dependent on the subsequent production of IFN $\gamma^{54}$. ApoE ${ }^{-1} / \mathrm{IL}-18^{-1}$ double knockout mice, on the other hand, show a marked reduction in lesion size, further confirming the notion that IL-18 is a proatherogenic cytokine, which most likely acts by promoting the development of IFN $\gamma$ secreting Th 1 cells ${ }^{10}$. Furthermore, human atheroma express IL-18 in macrophages and elevated levels of its receptor subunits IL-18R $\alpha / \beta$ on smooth muscle cells, endothelial cells and macrophages. In these cells IL-18 signaling evoked effectors involved in atherogenesis, e.g. IL-6, IL-8, ICAM-1 and matrix metalloproteinases 1,9 and $3^{16}$. Similar to $\mathrm{IL}-18, \mathrm{IL}-12$ has been associated with atherosclerosis. By RT-PCR, immunohistochemistry and in situ hybridization IL-12 has been shown to be present in human and mouse atherosclerotic plaques ${ }^{29,49}$. Furthermore, daily administration of IL-12 led to an increase in serum levels of anti-oxLDL antibodies and accelerated atherosclerosis in apoE $\mathrm{E}^{+}$mice ${ }^{29}$. In addition, apoE ${ }^{*} / \mathrm{IL}-12^{+-}$double knockout mice had a $52 \%$ reduction in plaque area in the aortic root at 30 weeks of age compared with normal apoE $\mathrm{E}^{l}$ mice ${ }^{8}$. Similar results have been obtained with exogenous IFN $\gamma$ infusions ${ }^{53}$ or apoE ${ }^{-1} /$ IFN $\gamma$ receptor $^{-1-}$ double knockout mice ${ }^{21}$. Furthermore, Whitman et al. demonstrated that IL-18 enhances atherosclerosis in $\mathrm{apoE}^{-1}$ mice through the release of IFN $\gamma^{54}$. Taken together, these data suggest an important role for the interplay between IL-12, IL-18 and the subsequent production of IFN $\gamma$ in accelerating atherosclerosis. Furthermore, the fact that lesion size was diminished in C57BL/6J mice lacking the TNF receptor p55 suggests that TNF $\alpha$ also influences atherosclerosis ${ }^{43}$. This is strengthened by the fact that repeated LPS injections, which result in significant elevation in plasma TNF $\alpha$ levels, resulted in an $83 \%$ increase in lesion size in apoE mice ${ }^{35}$. Intriguingly, most of these aspects were also observed in our apoE mice following MCMV infection: IL-12 and IL-18 production by macrophages was elevated following MCMV infection (chapter 7) and MCMV infection resulted in high IFN $\gamma$ and TNF $\alpha$ plasma levels (chapter 6). Recently it has also been 
demonstrated that plasma levels of IL-12 and IL-18 become elevated following MCMV infection ${ }^{36}$. Therefore, based on these data we now hypothesize that CMV infections affect atherosclerosis in part by an indirect effect mediated by the systemic increase of pro-inflammatory and pro-atherogenic cytokines.

\section{Direct effects in the vascular wall}

In addition to their role in viral control ${ }^{20}$, macrophages are generally accepted to be likewise responsible for viral dissemination ${ }^{44}$. Therefore, the dissemination of MCMV after intraperitoneal infection to all organs including the vascular wall (chapters $3,4,6,7$ ) may have been mediated by infected peritoneal monocytes/macrophages. In chapter $\mathbf{5}$ we demonstrated that intraperitoneal MCMV injection results in macrophage recruitment to the peritoneal cavity. Infection of these macrophages directed them to a proinflammatory immune phenotype characterized by the production of IL-12, IL-18 and IFN $\gamma$ and the increased expression of cell surface molecules such as MHC class II, CD40, CD80 and CD86 involved in antigen presentation to $T$ cells. However, it still remains to be established whether these macrophages are responsible for viral dissemination or whether dissemination depends on more "naïve" macrophages containing CMV. Irrespective of the carrier macrophage, latent CMV may reactivate in these transport-macrophages after vascular wall contact ${ }^{19}$ or by monocyte-to-macrophage differentiation ${ }^{45}$. If transport is mediated by "naive" monocytes, CMV reactivation may direct macrophages into a pro-inflammatory immune phenotype thereby attracting $T$ cells to the vascular wall. This could then explain the increased $T$ cell influx observed in atherosclerotic lesions of $\mathrm{apoE}^{-1}$ mice following $\mathrm{MCMV}$ infection (chapters 2 and 4). Subsequent $T$ cell activation may then stimulate the ongoing inflammation in the atherosclerotic vascular wall and aggravate atherosclerosis. On the other hand, CMV reactivation may result in viral spread to neighboring cells. Infection of neighboring macrophages leads in turn in a pro-inflammatory immune phenotype thereby further stimulating $T$ cell influx. Alternatively, CMV may infect local smooth muscle cells and endothelial cells and mediate direct effects which influence the development and/or the progression of atherosclerotic lesions. CMV infection of smooth muscle cells may stimulate smooth muscle cell proliferation and migration 55,58 and may make them vulnerable to NK-mediated lysis ${ }^{7}$, thereby enhancing fibrous cap formation in the advanced stages of atherosclerosis. Furthermore, CMV may induce a procoagulant phenotype in endothelial cells, thereby increasing the risk of thrombus formation ${ }^{51}$. Alternatively, CMV may increase MHC class I expression on the membrane of endothelial cells, thereby mediating endothelial cytotoxicity by $\mathrm{CD}^{+} \mathrm{T}$ cells ${ }^{50}$. Yet other data suggests that an increased formation of lipidladen foam cells may be mediated by CMV modification of low density lipoprotein uptake and scavenger receptor mRNA expression in vascular smooth muscle cells ${ }^{57}$. As a final example of the direct effects of CMV on atherosclerotic disease progression, IL-6 production by infected endothelial cells ${ }^{1}$ may stimulate smooth muscle cells to evolve into foam cells ${ }^{27}$. Thus, although data suggests that CMV affects the atherosclerotic process via an indirect way, we cannot exclude direct effects of CMV on components of the vascular wall since CMV can be demonstrated in the vascular wall itself. 


\section{An alternative mechanism: autoimmunity}

In various chapters of the present thesis, we present evidence for CMVaccelerated atherosclerosis by both direct mechanisms (involving CMV presence in the vascular wall) and indirect mechanisms (involving systemic production of pro-inflammatory cytokines). In chapter 4 , however, we found evidence for a third mechanism by which MCMV may aggravate the disease. When we injected UV-inactivated MCMV into the peritoneal cavity, increases in lesion size similar to those induced by viable MCMV were observed. Furthermore, T cell influx in atherosclerotic lesions occurred irrespective of the presence of virus in the vascular wall. In other organs, such as the spleen or liver, increases in T cell influx were only observed after viable MCMV injection. In other words, UV-inactivated MCMV led to T cell influx in atherosclerotic lesions but not in any other organs. These results inspired us to proffer a new hypothesis for a role of CMV in atherosclerosis. After injection of UV-inactivated MCMV into the peritoneal cavity, UV-MCMV induces a local immune response. This local immune responses may involve the formation of $T$ cell or antibodies directed against MCMV antigens. As the injection of UV-inactivated MCMV resulted in a marked increase in T cells in the vascular wall despite the absence of virus in the vascular wall we speculate that some of these T cells display cross-reactivity against autoantigens in the vascular wall. These autoreactive $T$ cells then enter the vascular wall and accelerate lesion formation by producing various pro-inflammatory and pro-atherogenic cytokines. Although it has been demonstrated that infections with Chlamydia pneumoniae may affect atherosclerosis in a similar way (e.g. based on the sequence homology between Chlamydia HSP60 (Heat Shock Protein 60) and host HSP60 ${ }^{28}$ ), this concept is rather unknown for MCMV and additional experiments are needed to further test this hypothesis.

\section{CONCLUSIONS AND PERSPECTIVES}

The suggestion that cytomegalovirus may aggravate vascular diseases, such as restenosis, transplantation-associated arteriosclerosis or atherosclerosis, was posed more than three decades ago. Since then, this association has been confirmed in various sero-epidemiological studies as well as in vitro and in vivo studies. Unfortunately, the majority of these papers, and in particular those focusing on atherosclerosis, remain descriptive in nature. In the present thesis, we have deviated from the descriptive path to unravel some of the mechanisms which may be involved in the aggravation of the atherosclerotic disease in a well-characterized animal model for atherosclerosis, the apoE mouse. We repeatedly found evidence that MCMV accelerates disease progression in these mice. More importantly, we also provide data supporting at least three processes by which CMV contributes to aggravation of atherosclerosis (Fig. 1). 


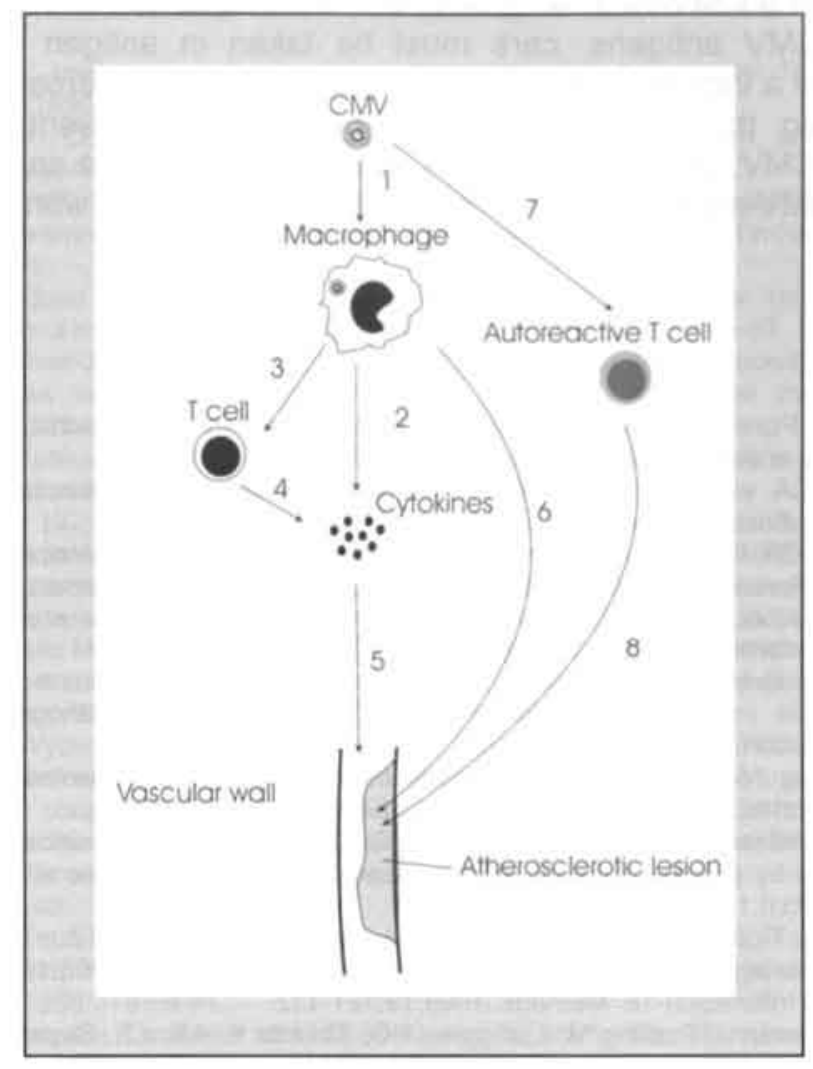

Fig. 1. Summary of MCMV-mediated effects on atherosclerosis. (1) After MCMV infection macrophages differentiate to a pro-inflammatory immune phenotype. (2) This phenotype is characterized by increased pro-atherogenic cytokine secretion. (3) In addition. CMV infection of macrophages induces increased expression of immune markers which may present viral antigens and activate $T$ cell responses. (4) This may also lead to pro-atherogenic cytokine secretion by $T$ cells. (5) These secreted pro-atherogenic cytokines may systemically mediate atherosclerosis aggravation. (6) Infected macrophages may also mediate CMV transport to the vascular wall, thereby locally inducing aggravating of the atherosclerotic process. (7) Alternatively. MCMV may lead to an autoreactive T cell response $(8)$ which may be directed to the vascular wall to mediate auto-immune/cytotoxic effects on the vascular wall.

Firstly, MCMV may affect lesion formation by inducing a systemic inflammatory response resulting in the production of various pro-atherogenic cytokines (IL-12, IL-18, IFN $\gamma$ and TNF $\alpha$ ), which stimulate lesion progression by a "remote" mechanism (chapters 5, 6, 7). Secondly, as MCMV DNA could be demonstrated in the vascular wall direct effects of MCMV on vascular wall components remain a possibility (chapters $3,4,6,7$ ). Finally, the results presented in chapter 4 suggest that autoreactive T cell, formed in response to MCMV antigen challenge, may contribute to the acceleration of plaque formation. While all three processes are worthy of further research attention, the possibility of autoimmune responses to CMV antigens deems special consideration as many research groups worldwide are devoted to the 
development of a CMV-vaccine. If auto-immune responses develop as a crossreactivity to CMV antigens, care must be taken in antigen choice for the development of a vaccine that does not accelerate atherosclerosis.

Considering the fact that $70 \%$ of the population eventually becomes infected with CMV, precise elucidation of the direct, indirect and auto-immune effects of CMV-mediated atherosclerotic acceleration warrant additional research.

\section{- REFERENCES}

1. Almeida GD, Porada CD, St Jeor $\mathrm{S}$, Ascensao JL. Human cytomegalovirus alters interleukin-6 production by endothelial cells. Blood. 1994;83:370-376.

2. Bruggeman CA, van Dam JG. Role of cytomegalovirus infection in transplant arteriosclerosis. Monogr Virol. Basel, Karger. 1998;21:158-172.

3. Bruggemans CA. Does cytomegalovirus play a role in atherosclerosis. Herpes. 2000;7:51-54.

4. Bruning JH, Persoons M, Lemstrom K, Stals FS, De Clercq E, Bruggeman CA. Enhancement of transplantation-associated atherosclerosis by CMV, which can be prevented by antiviral therapy in the form of HPMPC. Transpl Int. 1994:7 Suppl 1:S365-370.

5. Burnett MS, Gaydos CA, Madico GE, Glad SM, Paigen B, Quinn TC, Epstein SE. Atherosclerosis in apoE knockout mice infected with multiple pathogens, $J$ Infect Dis. 2001:183:226-231.

6. Conti B, Jahng JW, Tinti C, Son JH, Joh TH. Induction of interferon-gamma inducing factor in the adrenal cortex. J Biol Chem. 1997:272:2035-2037.

7. Datta SK, Tumilowicz JJ, Trentin JJ. Lysis of human arterial smooth muscle cells infected with herpesviridae by peripheral blood mononuclear cells: implications for atherosclerosis. Viral Immunol. 1993;6:153-160.

8. Davenport P. Tipping PG. The role of interleukin-4 and interleukin-12 in the progression of atherosclerosis in apolipoprotein E-deficient mice. Am J Pathol. 2003;163:1117-1125.

9. Dinarello CA. Interleukin-18. Methods. 1999;19:121-132.

10. Elhage R, Jawien J, Rudling M, Ljunggren HG, Takeda K, Akira S, Bayard F. Hansson GK. Reduced atherosclerosis in interleukin-18 deficient apolipoprotein E-knockout mice. Cardiovasc Res. 2003:59:234-240.

11. Ellis RW. Infection and coronary heart disease. J Med Microbiol. 1997:46:535-539.

12. Epstein SE, Zhou YF, Zhu JH. Potential role of cytomegalovirus in the pathogenesis of restenosis and atherosclerosis. Am Heart J. 1999;138:S476-S478.

13. Epstein SE. The multiple mechanisms by which infection may contribute to atherosclerosis development and course. Circ Res. 2002;90:2-4.

14. Fabricant CG, Fabricant J, Litrenta MM, Minick CR. Virus-induced atherosclerosis. J Exp Med. 1978:148:335-340.

15. Fei GZ, Huang $\mathrm{YH}$, Swedenborg J, Frostegard J. Oxidised LDL modulates immune-activation by an IL-12 dependent mechanism. Atherosclerosis. 2003;169:77-85.

16. Gerdes N, Sukhova GK, Libby P, Reynolds RS, Young JL, Schonbeck U. Expression of interleukin (IL)-18 and functional IL-18 receptor on human vascular endothelial cells, smooth muscle cells, and macrophages: implications for atherogenesis. J Exp Med. 2002;195:245-257.

17. Gibbs RG. Carey N, Davies AH. Chlamydia pneumoniae and vascular disease. Br J Surg. 1998:85:1191-1197.

18. Gribaudo G, Ravaglia S, Caliendo A, Cavallo R, Gariglio M, Martinotti MG, Landolfo S. Interferons inhibit onset of murine cytomegalovirus immediate-early gene transcription. Virology. 1993:197:303-311.

19. Guetta E. Guetta V. Shibutani T, Epstein SE. Monocytes harboring cytomegalovirus: interactions with endothelial cells, smooth muscle cells, and oxidized low-density lipoprotein. Possible mechanisms for activating virus delivered by monocytes to sites of vascular injury. Circ Res. 1997:81:8-16.

20. Guidotti LG, Chisari FV. Noncytolytic control of viral infections by the innate and adaptive immune response. Annu Rev Immunol. 2001:19:65-91.

21. Gupta S, Pablo AM, Jiang X, Wang N, Tall AR, Schindler C. IFN-gamma potentiates atherosclerosis in ApoE knock-out mice. J Clin Invest. 1997;99:2752-2761. 
22. Gupta S, Camm A.J. Is there an infective aetiology to atherosclerosis? Drugs and aging. 1998:13:1-7.

23. Hansson GK. Immune mechanisms in atherosclerosis. Arterioscler Thromb Vasc Biol. 2001:21:1876-1890.

24. Hosenpud JD. Coronary artery disease after heart transplantation and its relation to cytomegalovirus. Am Heart J. 1999:138:S469-S472.

25. Hsich E, Zhou YF, Paigen B, Johnson TM, Burnett MS, Epstein SE, Cytomegalovirus infection increases development of atherosclerosis in Apolipoprotein-E knockout mice. Atherosclerosis. 2001:156:23-28.

26. Kalii RS, Hudson SL, Gaston RS. Determinants of cardiovascular mortality after renal transplantation: a role for cytomegalovirus? Am J Transplant. 2003;3:79-81.

27. Klouche M, Rose-John S, Schmiedt W. Bhakdi S. Enzymatically degraded, nonoxidized LDL induces human vascular smooth muscle cell activation, foam cell transformation, and proliferation. Circulation. 2000:101:1799-1805.

28. Lamb DJ, El-Sankary W, Ferns GA. Molecular mimicry in atherosclerosis: a role for heat shock proteins in immunisation. Atherosclerosis. 2003;167:177-185.

29. Lee TS, Yen HC, Pan CC, Chau LY. The role of interleukin 12 in the development of atherosclerosis in ApoE-deficient mice. Arterioscler Thromb Vasc Biol. 1999:19:734-742.

30. Mattila KJ, Valtonen W. Nieminen MS, Asikainen S. Role of infection as a risk factor for atherosclerosis, myocardial infarction, and stroke. Clin Infect Dis. 1998;26:719-734.

31. Munder M. Mallo M, Eichmann K, Modolell M. Murine macrophages secrete interferon gamma upon combined stimulation with interleukin (IL)-12 and IL-18: A novel pathway of autocrine macrophage activation. J Exp Med. 1998;187:2103-2108.

32. Naghavi M, Wyde P, Litovsky S, Madjid M, Akhtar A, Naguib S, Siadaty MS, Sanati S, Casscells W. Influenza infection exerts prominent inflammatory and thrombotic effects on the atherosclerotic plaques of apolipoprotein E-deficient mice. Circulation. 2003;107:762-768.

33. Nakashima Y, Plump AS, Raines EW, Breslow JL, Ross R. ApoE-deficient mice develop lesions of all phases of atherosclerosis throughout the arterial tree. Arterioscler Thromb. 1994:14:133-140.

34. Okamura $\mathrm{H}$, Tsutsi $\mathrm{H}$, Komatsu T, Yutsudo M, Hakura A, Tanimoto T, Torigoe $\mathrm{K}$, Okura T, Nukada $Y$. Hattori $K$, et al. Cloning of a new cytokine that induces IFN-gamma production by $T$ cells. Nature. 1995:378:88-91.

35. Ostos MA, Recalde D. Zakin MM, Scott-Algara D. Implication of natural killer T cells in atherosclerosis development during a LPS-induced chronic inflammation. FEBS Lett. 2002:519:23-29.

36. Pien GC, Satoskar AR, Takeda K. Akira S, Biron CA. Cutting edge: selective IL-18 requirements for induction of compartmental IFN-gamma responses during viral infection. $J$ Immunol. 2000;165:4787-4791.

37. Pirhonen J, Sareneva T, Kurimoto M. Julkunen I, Matikainen S. Virus infection activates IL-1 beta and IL-18 production in human macrophages by a caspase-1-dependent pathway. $J$ Immunol. 1999:162:7322-7329.

38. Presti RM, Pollock JL, DalCanto A.J, AK OG, Virgin HW, Interferon gamma regulates acute and latent murine cytomegalovirus infection and chronic disease of the great vessels. J Exp Med. 1998:188:577-588.

39. Qin L, Ding Y, Pahud DR, Chang E, Imperiale MJ, Bromberg JS. Promoter attenuation in gene therapy: interferon-gamma and tumor necrosis factor-alpha inhibit transgene expression. Hum Gene Ther. 1997;8:2019-2029.

40. Reinhardt B, Minisini R, Mertens T. Opinion article: cytomegalovirus is a risk factor in atherogenesis. Herpes. 2002;9:21-23.

41. Rott D, Zhu J, Burnett MS, Zhou YF. Zalles-Ganley A, Ogunmakinwa J, Epstein SE. Effects of MF-tricyclic, a selective cyclooxygenase-2 inhibitor, on atherosclerosis progression and susceptibility to cytomegalovirus replication in apolipoprotein-E knockout mice. J Am Coll Cardiol. 2003:41:1812-1819.

42. Saikku P. Chlamydia pneumoniae and atherosclerosis--an update. Scand J Infect Dis Suppl. 1997:104:53-56.

43. Schreyer SA, Peschon JJ, LeBoeuf RC. Accelerated atherosclerosis in mice lacking tumor necrosis factor receptor p55. J Biol Chem. 1996;271:26174-26178.

44. Sinclair J, Sissons $P$. Latent and persistent infections of monocytes and macrophages. Intervirology. 1996;39:293-301. 
45. Soderberg-Naucler C, Streblow DN, Fish KN, Allan-Yorke J, Smith PP, Nelson JA. Reactivation of latent human cytomegalovirus in $\mathrm{CD} 14(+)$ monocytes is differentiation dependent. J Virol. 2001:75:7543-7554.

46. Speir E, Modali R. Huang ES, Leon MB. Shawl F. Finkel T, Epstein SE. Potential role of human cytomegalovirus and p53 interaction in coronary restenosis [see comments]. Science. 1994:265:391-394.

47. Stoll S, Muller G, Kurimoto M. Saloga J, Tanimoto T, Yamauchi H, Okamura H. Knop J, Enk $\mathrm{AH}$. Production of IL-18 (IFN-gamma-inducing factor) messenger RNA and functional protein by murine keratinocytes. J Immunol. 1997:159:298-302.

48. Udagawa N, Horwood NJ, Elliott J, Mackay A, Owens J, Okamura H, Kurimoto M, Chambers TJ, Martin TJ, Gillespie MT. Interleukin-18 (interferon-gamma-inducing factor) is produced by osteoblasts and acts via granulocyte/macrophage colony-stimulating factor and not via interferon-gamma to inhibit osteoclast formation. J Exp Med. 1997;185:1005-1012.

49. Uyemura K, Demer LL, Castle SC, Jullien D, Berliner JA, Gately MK, Warrier RR, Pham N, Fogelman AM, Modlin RL. Cross-regulatory roles of interleukin (IL)-12 and IL-10 in atheroscierosis. J Clin Invest. 1996;97:2130-2138.

50. van Dorp WT, Jonges E, Bruggeman CA, Daha MR, van Es LA, van Der Woude FJ. Direct induction of MHC class I, but not class II, expression on endothelial cells by cytomegalovirus infection. Transplantation. 1989:48:469-472.

51. Vercellotti GM. Effects of viral activation of the vessel wall on inflammation and thrombosis. Blood Coagul Fibronolysis. 1998;9 Suppl. 2:S3-S5.

52. Watford WT, Moriguchi M, Morinobu A, O'Shea JJ. The biology of IL-12: coordinating innate and adaptive immune responses. Cytokine Growth Factor Rev. 2003:14:361-368.

53. Whitman SC, Ravisankar P, Elam H, Daugherty A. Exogenous interferon-gamma enhances atherosclerosis in apolipoprotein E-/- mice. Am J Pathol. 2000;157:1819-1824.

54. Whitman SC, Ravisankar P. Daugherty A. Interleukin-18 enhances atherosclerosis in apolipoprotein $\mathrm{E}(-/)$ mice through release of interferon-gamma. Circ Res. 2002:90:E34-38.

55. Yonemitsu Y, Kaneda Y, Komori K, Hirai K, Sugimachi K, Sueishi K. The immediate early gene of human cytomegalovirus stimulates vascular smooth muscle cell proliferation in vitro and in vivo. Biochem Biophys Res Commun. 1997;231:447-451.

56. Zhang SH, Reddick RL, Piedrahita JA, Maeda N. Spontaneous hypercholesterolemia and arterial lesions in mice lacking apolipoprotein E. Science. 1992;258:468-471.

57. Zhou YF, Guetta E, Yu ZX, Finkel T, Epstein SE. Human cytomegalovirus increases modified low density lipoprotein uptake and scavenger receptor mRNA expression in vascular smooth muscle cells. J Clin Invest. 1996;98:2129-2138.

58. Zhou YF, Yu ZX, Wanishsawad C. Shou M, Epstein SE. The immediate early gene products of human cytomegalovirus increase vascular smooth muscle cell migration, proliferation, and expression of PDGF beta-receptor. Biochem Biophys Res Commun. 1999;256:608-613. 


\section{Samenvatting}

Infecties met cytomegalovirus (CMV) komen wijdverspreid voor. Hoewel infecties met dit virus meestal zonder klinische symptomen verlopen, kunnen ze ernstige problemen veroorzaken (o.a. retinitis, hepatitis en colitis) in immuungecompromiteerde patiënten zoals pasgeborenen en transplantatiepatiënten. Recent is ook gesuggereerd dat CMV een rol speelt in de ontwikkeling van atherosclerose (aderverkalking). Atherosclerose is een chronische ziekte van de middelgrote en grote vaten waarvan de klinische symptomen (hartinfarct, beroerte, gangreen) zich uiten na partiële of totale afsluiting van het vaatlumen. Aangezien atherosclerose nog steeds één van de belangrijkste doodsoorzaken in de Westerse Wereld is, is de identificatie en eliminatie van alle mogelijke risicofactoren voor atherosclerose uitermate relevant. In dit proefschrift is daarom de bijdrage van $\mathrm{CMV}$ aan het atherosclerotische proces nader onderzocht.

Bij aanvang van deze promotiestudie was slechts weinig bekend over de bijdrage van CMV aan atherosclerose. Hoewel een associatie van het virus met de ziekte was aangetoond in sero-epidemiologische, in in vitro en in enkele in vivo experimenten, ontbraken eenduidige data over een bijdrage van het virus aan het atherosclerotische proces. Om deze bijdrage in detail te onderzoeken werd in dit proefschrift gebruik gemaakt van een diermodel nl. de atherosclerose-gevoelige apolipoproteine $\mathrm{E}$ knockout $\left(\mathrm{apoE}^{-/}\right)$muis. Door het ontbreken van het apoE gen, betrokken bij het vetmetabolisme, krijgen deze muizen hoge bloedcholesterol niveaus en ontwikkelen ze atherosclerose op een manier vergelijkbaar met de manier waarop mensen de ziekte ontwikkelen. Om het effect van CMV op de ontwikkeling van atherosclerose in deze muizen te bestuderen, werden jong volwassen (8-weken-oude) apoE ${ }^{-*}$ muizen geïnfecteerd met muis CMV (MCMV).

In een eerste experimenteel hoofdstuk (hoofdstuk 2) werd het effect van CMV infectie op het atherosclerotische proces beschreven. Hiertoe werden zowel tijdens de acute fase ( 2 weken) als tijdens de chronische fase ( 20 weken) van de infectie de vaten van apo: $\mathrm{E}^{-/}$muizen geanalyseerd op de aanwezigheid van atherosclerose. Ook werd de grootte van athero-sclerotische lesies gemeten en vergeleken met vaten van niet-geïnfecteerde muizen. Hoewel in de acute fase van de infectie geen effect van MCMV op het atherosclerotische proces gezien werd, was op 20 weken na infectie de atherosclerotische lesiegrootte significant toegenomen. Met andere woorden, CMV infectie van de muis resulteerde in een versnelde progressie van atherosclerose. Op de arteriën van deze muizen werden eveneens immunohistochemische kleuringen uitgevoerd teneinde de influx van $T$ cellen en macrofagen te meten. Hoewel $M C M V$ infectie niet resulteerde in een effect op het aantal macrofagen, was het aantal T cellen in de vaatwand in de acute fase van de infectie ( 2 weken) significant verhoogd ten opzichte van de vaten van niet-geïnfecteerde dieren. Deze resultaten toonden dus aan dat MCMV het atherosclerotische proces 
versterkt in apoE muizen tijdens de chronische fase van de infectie en dat de T lymfocyt hier wellicht een bijdrage in levert.

In de volgende hoofdstukken is vervolgens getracht meer inzicht te krijgen in de mechanismen die ten grondslag liggen aan de geobserveerde stimulatie van atherosclerose door CMV. De experimentele opzet werd zo gekozen dat zowel indirecte effecten (door ontstekingsreacties) als directe effecten (door de aanwezigheid van CMV in de vaatwand) van het virus op atherosclerose onderzocht konden worden.

Omdat we wilden nagaan of het waargenomen effect (uit hoofdstuk 2) enkel en alleen veroorzaakt werd door infectieus virus of dat ook niet-infectieus virus dit effect teweeg kon brengen, werd een experiment opgezet waarbij apoE ${ }^{-1-}$ muizen geïnjecteerd werden met geïnactiveerd virus (hoofdstuk 4). Het virus dat hiervoor gebruikt werd, was replicatie-deficiënt gemaakt door middel van UV bestraling. Uit deze studie bleek dat zowel infectieus als UV-geïnactiveerd MCMV een invloed hadden op het atherosclerotische proces in de acute fase van de infectie en dat beiden een toename in $T$ cellen in de vaatwand induceerden. Zoals verwacht, konden er geen virale componenten in de vaatwand gedetecteerd worden na UV-MCMV injectie. De resultaten van dit experiment zijn in overeenstemming met bevindingen van andere groepen. Deze suggereren dat infecties, ook degene die niet leiden tot infectie van de vaatwand, het reeds op gang zijnde atherosclerotische proces kunnen stimuleren. Dit is een belangwekkende bevinding omdat ze aangeeft dat stimulatie van het immuunsysteem door een "willekeurige" infectie wellicht het atherosclerotische proces versnelt.

Naast T cellen spelen macrofagen ook een belangrijke rol in het atherosclerotische proces. Ook is bekend dat virussen macrofagen kunnen activeren. Om te onderzoeken of MCMV via macrofaag gemedieerde immuunreacties op indirecte wijze het atherosclerotische proces kan verergeren, werd in hoofdstuk 5 het effect van MCMV op macrofaagdifferentiatie bestudeerd. In het bijzonder werd aandacht besteed aan het proinflammatoire/pro-atherogene fenotype. Hiertoe werd het effect van MCMV infectie op de productie van pro-inflammatoire/pro-atherogene cytokines zoals interferon- $\gamma$ (IFN $\gamma$ ) en interleukine-18 (IL-18) door peritoneaal macrofagen bepaald. Tevens werd met behulp van de FACS (fluorescent activated cell sorting) techniek de expressie van het celmembraan molecule MHC (Major histocompatibility complex) klasse II en de co-stimulatoire celmembraan moleculen CD40, CD80 en CD86, die allen betrokken zijn bij T cel activatie, bestudeerd. Uit deze studie bleek dat MCMV infectie macrofagen stimuleert tot IL-18 secretie en dat MCMV infectie een verhoogde IFN $\gamma$ productie door macrofagen veroorzaakt. Eveneens resulteerde MCMV infectie in een verhoogde expressie van de hierboven beschreven celmembraan markers. Hieruit kan geconcludeerd worden dat MCMV een pro-inflammatoir/proatherogeen macrofaag fenotype induceert hetgeen impliceert dat het virus ook via deze weg een effect kan hebben op het atherosclerotische proces. 
Eerdere studies hebben aangetoond dat cytokines een bijdrage kunnen leveren aan het atherosclerotische proces. Op basis hiervan werd een volgend experiment uitgevoerd waarbij gekeken werd of CMV een invloed heeft op de hoeveelheid cytokines in het bloed en in de vaatwand (hoofdstuk 6). Hiertoe werden IFN $\gamma$ en tumor necrosis factor $\alpha$ (TNF $\alpha$ ) concentraties gemeten in het bloed met behulp van de ELISA (enzyme linked immuno sorbent assay) en werd de expressie van deze cytokines gemeten in de arteriële vaatboom met behulp van de real-time RT-PCR. Uit dit onderzoek bleek dat MCMV leidt tot een verhoogde concentratie van zowel TNF $\alpha$ als van IFN $\gamma$ in het bloed op 2 à 4 dagen na infectie. Aangezien verhoogde systemische niveaus van deze cytokines atherosclerose kunnen verergeren, suggereren deze resultaten dat $\mathrm{CMV}$ via een indirect mechanisme (i.e. systemische expressie van cytokines) het atherosclerotisch proces kan verergeren. Naast een verhoogde systemische productie bleken deze cytokines ook lokaal in de vaatwand van apoE muizen aanwezig te zijn, waarbij het percentage vaten positief voor deze cytokines hoger lag in de MCMV-geïnfecteerde muizen dan in mock-geïnjecteerde muizen. Het feit dat ook MCMV in de vaatwand van deze muizen kon gedetecteerd worden, suggereert dat infectieus virus lokale/directe effecten op de vaatwand kan hebben die resulteren in een verhoogde lokale cytokine expressie met als gevolg een verdere stimulatie van het atherosclerotische proces.

Om een direct effect op de vaatwand te kunnen hebben moet het virus van de plaats van infectie naar de vaatwand getransporteerd worden. Hoewel in het vorige experiment reeds aangetoond werd dat het virus in de vaatwand gedetecteerd kan worden, was de tijdsafhankelijke verspreiding van het virus in apo $\mathrm{E}^{-/}$muizen nog niet volledig bekend. Om dit te onderzoeken werd op diverse tijdstippen (1, 2, 4, 6, 14 en 28 dagen) na infectie de hoeveelheid MCMV DNA in verschillende organen bepaald (hoofdstuk 7). MCMV DNA kon reeds op 1 dag na infectie in de vaatwand gedetecteerd worden. Piek niveaus werden gedetecteerd op dag 4 à 6 na infectie, waarna er een geleidelijke afname kon worden waargenomen op 14 en 28 dagen na infectie. Een analoog patroon werd gezien in het hart en in de longen. In de milt, in het bloed en in de lever werden piek niveaus gedetecteerd op 2 dagen na infectie opgevolgd door een geleidelijke afname op latere tijdstippen. In de beenmergcellen werden continu lage niveaus aan MCMV gedetecteerd en in de speekselklier werden piek niveaus pas op de latere tijdstippen gedetecteerd. De resultaten van dit experiment tonen dus aan dat CMV zich reeds vroeg na infectie verspreidt in het lichaam en dat het virus aanwezig is in de vaatboom vanaf dag 1. In dit experimentele hoofdstuk werd eveneens een vergelijking gemaakt tussen apo $\mathrm{E}^{-/}$ en normale apoE-bevattende C57BL/6J muizen met betrekking tot MCMV gevoeligheid. Specifieke overlevingskarakteristieken van de muizen werden vergeleken naast de hoeveelheid van MCMV DNA in de verschillende organen. Een opmerkelijke bevinding was dat apoE $\mathrm{E}^{-/}$muizen beduidend minder gevoelig bleken te zijn voor MCMV infecties dan de C57BL/6J muis. Mogelijk is dit te wijten aan de verhoogde basale activiteit van het immuunsysteem die gedetecteerd werd in de apoE $\mathrm{E}^{*}$ muis. 
Concluderend kan gesteld worden dat de data, gepresenteerd in dit proefschrift, aanleiding geven om te veronderstellen dat CMV het atherosclerotische proces daadwerkelijk beïnvloedt. Mogelijk gebeurt deze beïnvloeding via 2 mechanismen i) via een direct/lokaal effect of ii) via een indirect/gegeneraliseerd effect. Welke van de mechanismen het belangrijkst is en hoe ze precies werken is nog grotendeels onbekend. Verder onderzoek is hiervoor noodzakelijk. 


\section{Dankwoord}

Eindelijk is het dan zover...mijn proefschrift is klaar! Hoewel niet altijd alles van een leien dakje liep, ben ik blij dat ik toch doorgezet heb om dit boekje tot een goed einde te brengen. Natuurlijk had ik dit niet kunnen verwezenlijken zonder de hulp van velen. Ik werd tijdens mijn promotieonderzoek namelijk omringd door een hele club van hulpvaardige collega's en toffe vrienden. En daarom: hartelijk bedankt allemaal!!!!!

Als eerste wil ik de mensen van de afdeling Biochemie van het L.U.C. in Diepenbeek en dan met name Luc Kupers danken. Luc, bij deze wil ik je bedanken om me in contact te hebben gebracht met Cathrien en de afdeling Medische Microbiologie in Maastricht. Hoewel het in eerste instantie de bedoeling was om in samenwerkingsverband alle dierproeven uit te voeren, werd in de loop van de experimenten de research-afdeling Biochemie te Diepenbeek helaas gesloten. Onze samenwerking was hierdoor jammer genoeg maar van korte duur en het proefdierwerk werd daardoor verdergezet in de centrale proefdiervoorzieningen van de Universiteit Maastricht. Daarom ook wil ik de mensen van het CPV Maastricht bedanken voor hun hulp. Paulien, Peter, Brigitte, Nadine, Harry, Sytske en Ton (in memoriam) hartelijk bedankt.

Verder wil ik Marjorie Nelissen, Roel Koch en Esther Lutgens bedanken voor hun hulp bij mijn eerste muisexperimenten. Marjorie, jou wil ik bedanken voor jouw hulp bij het overwinnen van mijn angsten om die wriemelende bijtende beestjes vast te pakken, te injecteren en te dissecteren. Ik dank je eveneens voor de opstap naar al mijn experimenten die je voor me achterliet toen je onze afdeling verliet. Tenslotte wil ik jou bedanken voor de fijne tijd in de Harmonie. Roel en Esther, jullie wil ik graag bedanken voor de hulp die jullie me boden bij het typeren van de atherosclerotische plaques.

Mijn 2 paranimfen Gert en Selma wil ik bedanken voor hun steun en helpende hand die ze me boden tijdens mijn promotieonderzoek en tijdens de voorbereiding van mijn promotie. Gert, jammer voor je dat je allergisch geworden bent voor proefdieren. Ik weet dat je het altijd fijn en afwisselend werk gevonden hebt. Gelukkig voor mij dat je kunnen hier niet toe beperkt bleef en dat je altijd trachtte tijd vrij te maken om mij uit de nood te helpen. Echter hetgeen waar ik je het meeste voor wil bedanken Gert, is je vriendschap. Selma, al die "tientallen" (of waren het nu "honderden") TaqMan runs en DNA isolaties die je voor me uitvoerde, hebben mij een heel stuk vooruitgeholpen. Je was zelfs zo gedreven dat je tijdens het opofferen van de muizen al langs me stond om de nodige organen te verzamelen en om er onmiddellijk mee aan de slag te gaan. Ik dank je daarom enorm voor het vele werk dat je voor me verzet hebt, maar ook voor de fijne babbels tijdens de lunch en de gezellige donderdagavonden.

Verder wil ik natuurlijk de rest van de research groep niet vergeten. Rajaa en Sabine, dank je wel voor jullie hulp bij mijn proefdierexperimenten. Geoffrey, Tryfon, Manuela, Marjan, Joanne, Jeroen, Rajaa en Tanja, bedankt voor de 
gezellige momenten en babbels. Ellen, jou wil ik bedanken voor je vriendschap. Toen je net aankwam op het lab en je je nog wat onwennig voelde had ik toch een beetje medelijden met je. Ik wist namelijk zoals geen ander hoe je je voelde om hier als "verlegen" Vlaamse aan te komen in een "Nederlands lab". Ik ben blij dat we het al snel goed met elkaar konden vinden en dat we zelfs buiten het werk om goede vriendinnen zijn geworden. Sita, mijn kamergenootje, jou wil ik ook bedanken voor je vriendschap. Naast de grote overeenkomst in studiekeuze, denk ik dat ik mag zeggen dat we ook op andere gebieden vrij goed overeenkomen. Een terrasje na het werk tezamen met Ellen en jou was altijd een fijne afsluiter van een vermoeiende week. Maartje, bedankt voor de babbels en succes met je opleiding in Brussel. Verder wil ik de mensen van het lab van "Erik en Kees" niet vergeten. Jullie vormen een absoluut gezellige beestenboel en ik heb me altijd goed geamuseerd op onze uitstapjes. Bedankt voor al het lekkers en de gezelligheid. Aan de heren van de "Helpdesk tel. 76642" (Patrick en Martijn), bedankt voor de vele back-ups, voor de FACS plaatjes en voor jullie technische hulp. Ik wou dat ik ook zo handig was met de computer... Martine Hulsbosch, Monique Coomans, Peter Terporten, Wil Mullers, de dames van het secretariaat (Fia, José, Patricia, Angèle) en de mensen van de spoelkeuken (Verius, John en Ans), eveneens bedankt voor jullie hulp.

Ook wil ik de volgende mensen van buiten de afdeling Medische Microbiologie nog even persoonlijk vermelden en bedanken voor hun bijdrage aan dit promotieboekje. Henk van Rie, Maria Vroomen, Peter Heijmans, Mohammed Hadfoune, Menno de Winther, Monique Vergouwe, allen hartelijk bedankt. Debbie, bedankt voor het nalezen van mijn proefschrift. Door jouw commentaren gingen de zinnen plots veel vlotter lopen.

Last but definitely not least... wil ik nog enkele dankwoorden richten aan mijn begeleiders Adriaan Duijvestijn, Frank Stassen en Cathrien Bruggeman. Frank, hoewel je wat later dan ik, op de afdeling Medische Microbiologie aankwam, had je je al heel snel ingewerkt in mijn onderzoeksonderwerp en ben je al heel snel een goede begeleider voor mij geworden. Zelfs wanneer ik je tot vervelenstoe met vragen kwam bestoken, nam je de tijd om me verder te helpen. Jouw makkelijke manier van schrijven was iets waar ik vaak naar opkeek en de goede tips die je me hieromtrent gaf nam ik daarom zeker in dank aan. Ad, dank je wel voor je begeleiding en voor je kritisch nazicht van het promotieboekje. Cathrien, hartelijk bedankt om mij de kans gegeven te hebben om bij jou op de afdeling als AIO te mogen beginnen. $\mathrm{Na}$ het mislopen van de NWO beurs in België, dacht ik immers dat promoveren er niet meer in zou zitten voor mij. Verder wil ik je bedanken voor je goede begeleiding en je luisterend oor.

Mijn dank gaat natuurlijk ook uit naar mijn ouders. Mama en papa, dank u wel om mij de kans gegeven te hebben om dit te verwezenlijken en hartelijk bedankt voor al uw steun en liefde. Papa u wil ik speciaal bedanken voor de tekening die je voor me maakte voor op de omslag van dit boekje. Ik ben er heel tevreden mee. Gerd en Tamara bedankt voor jullie steun. Michaël, merci beaucoup pour être la pour moi, pour m'aimer et pour m'aider avec tellement de choses. Tu es vraiment fantastique. 


\section{Curriculum vitae}

Inge Vliegen werd geboren te Tongeren op 23 januari 1977. In 1994 behaalde zij het diploma secundair onderwijs (Latijn-Wetenschappen Wiskunde $5 \mathrm{u}$ ) aan het Koninklijk Atheneum te Tongeren. In datzelfde jaar begon zij aan het Limburgs Universitair Centrum te Diepenbeek aan haar kandidatuurjaren Scheikunde. In 1996 koos zij voor de Universiteit Antwerpen om in 1998 met onderscheiding af te studeren als Licentiaat Biochemie. Het onderzoek voor haar afstudeerscriptie; "Functionele analyse van de promotor van het extracellulair matrix proteïne $1(\mathrm{Ecm}-1)$ van de muis: plaatsgerichte mutatie van de bindingsplaatsen van de transcriptiefactoren AP-1, SP-1, ETS en GATA", werd uitgevoerd onder de begeleiding van prof. dr. J. Merregaert van de vakgroep Biochemie aan de Universiteit Antwerpen. In 1999 startte zij vervolgens aan de opleiding "Assistent in Opleiding" in het azM/UM te Maastricht onder de begeleiding van dr. Frank Stassen en prof. dr. Cathrien Bruggeman (vakgroep Medische Microbiologie) en dr. Adriaan Duijvestijn (vakgroep Immunologie). Sedert 1 Juli 2003 is ze werkzaam binnen de vakgroep Medische Microbiologie op een project getiteld: "Snelle identificatie van bacteriën door middel van DNA-chip technologieën". 


\section{List of Publications}

\section{Full articles}

Inge Vliegen, Frank Stassen, Gert Grauls, Rien Blok, Cathrien Bruggeman. MCMV infection increases early T-lymphocyte influx in atherosclerotic lesions in apoE knockout mice. J Clin Virol. 2002 Aug;25 Suppl 2:159-171.

Inge Vliegen, Selma Herngreen, Gert Grauls, Cathrien Bruggeman, Frank Stassen. Improved detection and quantification of mouse cytomegalovirus by real-time PCR. Virus Res 2003 , in press.

Inge Vliegen, Ad Duijvestijn, Gert Grauls, Selma Herngreen, Cathrien Bruggeman, Frank Stassen. Cytomegalovirus infection aggravates atherogenesis in apoE knockout mice by both local and systemic immune activation. Microbes Infect, in press.

Rajaa Ezzahiri, Marjorie Nelissen-Vrancken, Harrie Kurvers, Frank Stassen, Inge Vliegen, Gert Grauls, Marloes van Pul, Peter Kitslaar, Cathrien Bruggeman. Chlamydophila pneumoniae (Chlamydia pneumoniae) accelerates the formation of complex atherosclerotic lesions in Apo E3-Leiden mice. Cardiovasc Res 2002 Nov; 56(2):269-76.

\section{Book section}

Frank Stassen, Inge Vliegen, Cathrien Bruggeman. CMV and Atherosclerosis. In: Prösch S, Cinatl J, Scholz M, eds. New aspects of CMV-related Immunopathology. Monogr. Virol. Basel, Karger, 2003, vol.24, p23-32.

\section{Abstracts}

Inge Vliegen, Marjorie Nelissen-Vrancken, Roel Koch, Gert Grauls, Joanne van Dam, André van der Ven, Mihai Netea, Mat Daemen, Cathrien Bruggeman. Cytomegalovirus (CMV) infection accelerates the development of atherosclerosis in apolipoproteinE (apoE) knock-out mice. Circulation (suppl), 2000, 102(18): II-54 (abstract).

Inge Vliegen, Selma Herngreen, Gert Grauls, Sabine Stevens, Cathrien Bruggeman, Frank Stassen. Genotype differences determine cytomegalovirus dissemination in the mouse. NTvMM, april 2003 (suppl), S36 (abstract).

Rajaa Ezzahiri, Marjorie Nelissen-Vrancken, Harrie Kurvers, Inge Vliegen, Gert Grauls, Cathrien Bruggeman, Peter Kitslaar. Chlamydia pneumoniae induces a change in type of atherosclerotic lesions in ApoE3 Leiden transgenic mice. Circulation (suppl), 2000, 102(18); II-53 (abstract). 

